\title{
Plan for addressing issues relating to oil shale plant siting
}

Noridin, J.S.; Donovan, R.; Trudell, L.; Dean, J.; Blevins, A.; Harrington, L.W.; James, R.; Berdan, G.

Sep 1987

Western Research Inst., Laramie, WY (USA)

Reproduced and Distributed by:

U.S. DEPARTMENT OF ENERGY

Office of Scientific and Technical Information

P.O. Box 62

Oak Ridge, TN 37831 


\section{DISCLAIMER}

This report was prepared as an account of work sponsored by an agency of the United States Government. Neither the United States Government nor any agency Thereof, nor any of their employees, makes any warranty, express or implied, or assumes any legal liability or responsibility for the accuracy, completeness, or usefulness of any information, apparatus, product, or process disclosed, or represents that its use would not infringe privately owned rights. Reference herein to any specific commercial product, process, or service by trade name, trademark, manufacturer, or otherwise does not necessarily constitute or imply its endorsement, recommendation, or favoring by the United States Government or any agency thereof. The views and opinions of authors expressed herein do not necessarily state or reflect those of the United States Government or any agency thereof. 


\section{DISCLAIMER}

Portions of this document may be illegible in electronic image products. Images are produced from the best available original document. 


\section{DISCI.AIMER}

This report was prepared as an account of work sponsored by an agency of the United States Government. Neither the United Siates Government nor ariy agency therenf, nor any of their employees, makes any warranty, express or implied, or assumes an, legall liability or responsibility for the accuracy, completeness, or usefulness of any information, apparatus, product, or process disclosed, or represents that its use would not infringe privately owned rights. Reference herein to any specific commercial product, process, or service by trade name, trademark, manufacturer, or otherwise does not necessarily constitute or imply its endorsement, recommendation, or favoring by the United States Government or any agency thereof. The views and upinons of authors expressed herein do not necessarily state or reflect those of the United States Government or any agency thereof.

This report has been reproduced directly from the best available copy.

Availabie from the National Technical Information Service, U. S. Department of Commerce, Springfield, Virginia 22161.

Price: Printed Copy Al6

Microfiche A01

Codes are used for pricing all publications. The code is determined by the number of pages in the publication. Information pertaining to the pricing codes can be found in the current issues of the following publications, which are generally available in most libraries: Energy Research Abstracts (ERA): Government Reports Announcements and Index (GRA and I); Scientific and Technical Abstract Reporis (SI AR); and publication NTIS-PR-360 available from NTIS at the above address. 


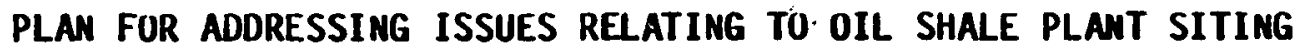

By

John S. Nordin

Robert Donovan

Laurence Trudel1

James Dean

Audie Blevins*

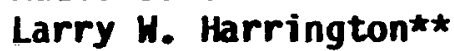

Rhonda James

Gretchen Berdan

September 1987

Hork Performed Under Cooperative Agreement

DE-FC21-83FE60177

For

U. S. Department of Energy

Office of Fossil Energy

Morgantown Energy Technology Center

Laramie Project office

Laramie, Wyoming

By

Western Research Institute

Laramie, Hyoming

*Sociology Department, University of Wyoming, Laramie, HY 82071

**Attorney at Law, Casper, WY 82602 
TABLE OF CONTENTS

Page

LIST OF TABLES............................... iv

LIST OF FIGURES............................... vi

SUMMARY.................................... vi

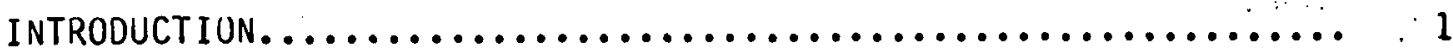

COMPARISON UF WRI TO LOS ALAMUS UIL SHALE SITING METHODOLOGY

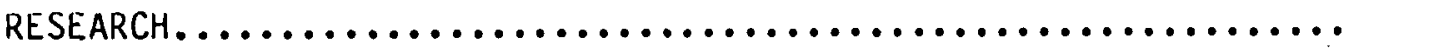

Phase 1. Resources............................. 5

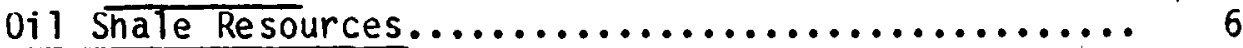

Characterizing 0it Shale Resources............... 8

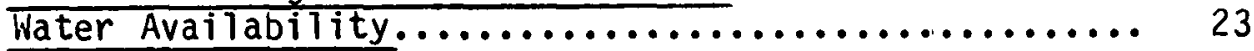

Topography and Transportation................... 33

Human Resources........................... 39

Phase 2. Restrictions on Resource Utilization.......... 73

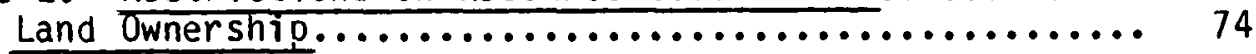

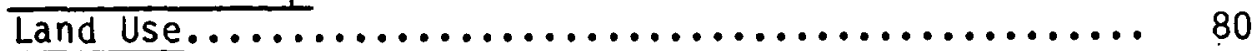

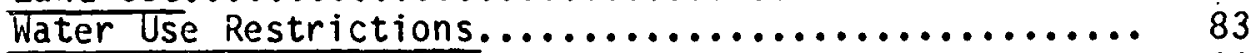

Restrictions on Emission to Air.................. 91

Restrictions on wastewater Discharges............. 94

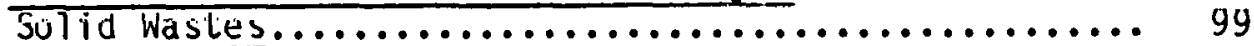

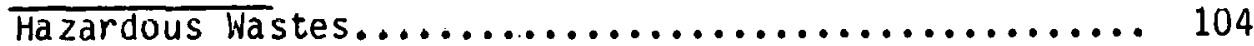

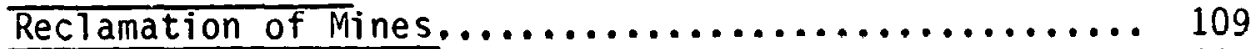

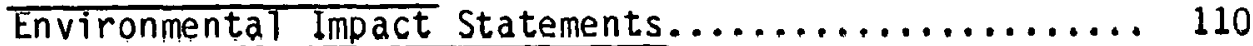

Heatth and Safety.......................... 113

Socioeconomic Restrictions Regarding Land Use........ 117

Antiquities (cultural Resources)................ 122

Permits to Develop Resource..................... 128

Phase 3. Process Technology for vil Snale Development..... 129 Generat Description of Process Technology........... 130

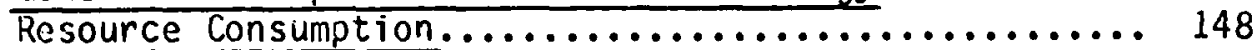

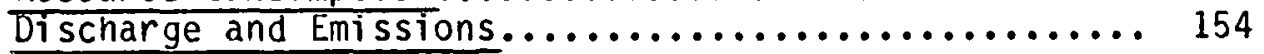

Phase 4. Impacts of 0il Shale Development............. 164

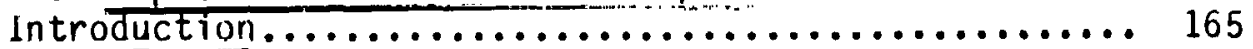

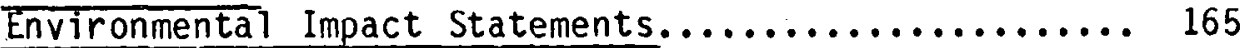

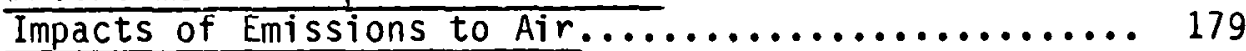

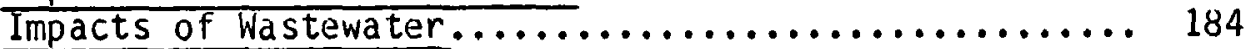

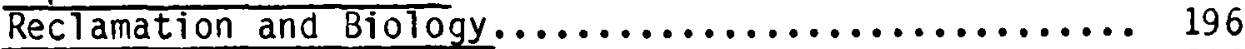

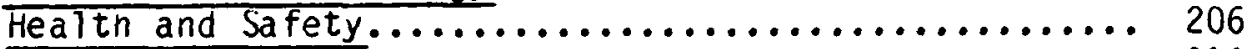

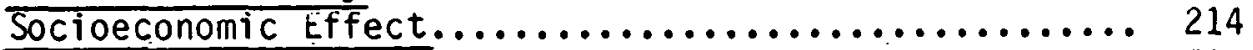

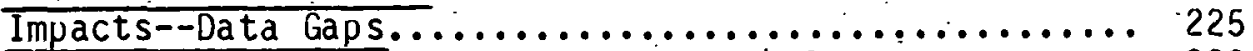

Examples of Research Needs - Water Quality........... 228

Loss of Resources......................... 229 
Phase 5. Proposed Research....................... 231

Flow Chart for 0il Shale Development............. 232

Siting Plan for Smal1 Demonstration Shale

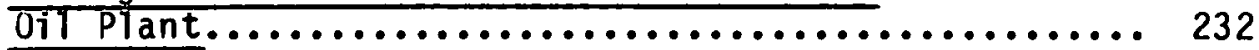

Resource Recovery............................ 233

Water Resources of Piceance Creek Basin............. 233

Disposal of Brines and Residues................. 234

In Situ and Modified In Situ Retorting............. 234

Processing Rich Shale......................... 235

Ecosystem Baseline Studies and Restoration.......... 236

APPENDIX A.................................... 237

List of State Statutes........................ 238

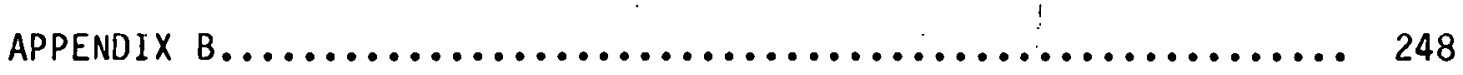

An Update of Permit Information System for Snale 0il...... 249 


\section{LIST OF TABLES}

Table

Page

1. Possible 0il Shale Deposit Requirements for Inclusion in the Siting Methodology Study..................... 8

2. Oil Shale Formations of the United States with Known Deposits More than 10 Feet Thick and Yielding More than 10 Gallons of 0il Per Ton......................

3. Average Annual Flows and Depletions, Upper Colorado

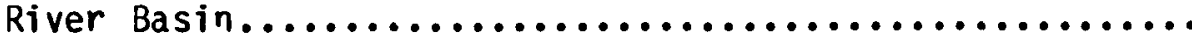

4. Average Flows of Major Rivers in Knobs Region of Kentucky...................................

5. Water Availability and Estimates for Proposed Uil Snale

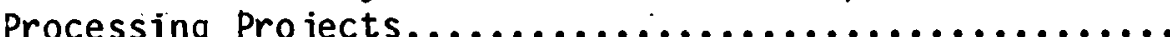

6. Properties of Raw Shale 0ils................... 33

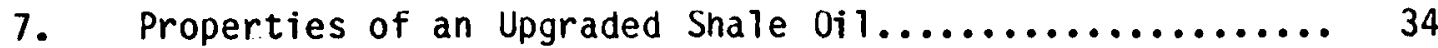

8. Manpower Requirements for Energy Facilities........... 40

9. Labor Force Estimates for 0il Snale Commercialization in Fleming County, Kentucky......................

10. Estimated Demand/Supply for Selected Crafts at 2600 Workers Peak Demand $(10,000$ bDl/day Plant $) \ldots \ldots \ldots \ldots$

11. Mạior Skill Requirements, Ful1-Size Module Construction.

12. Federal 0 il Shale Lands........................ 75

13. Non-Federal Oil Shale Lands with Clear Title (Includes Indian and State Lands)......................... 76

14. Federal 0il Shale Lands (Clouded Title)............. 77

15. Land Ownership for Eastern lit Sha18 Area............ 78

16. Land Use and Suitability...................... 81

17. Environmental Protection Agency Regulations on National Primary and Secondary Ambient Air Quality Standards...... 93

18. Cultural Resource Site Types..................... 123

19. $0 i 1$ Shale Mining............................ 131 


\section{List of Tables (Continued)}

$\underline{\text { Table }}$

Page

20. Surface Retorting Technologies, Direct Heating.......... 132

21. Surface Retorting Technologies, Indirect Heating........ 133

22. Surface Retorting Technologies, Hydrogen Enrichment...... 134

23. Surface Retorting Technologies, General............. 135

24. In Situ 0il Snale Processes..................... 136

25. Modified In Situ $0 i 1$ Shale Processes................. 137

26. Projected Water Balance at Four Model Shale 0il Plants... 151

27. Environmental Impact Statements.................. 166

28. Cancer Incidence and Fatality Rates................ 207

29. Summary of Pulmonary Disease Risk for 20,400 Workers

Exposed to Dust.............................. 208

30. Annual Accident and Injury Occurrences for a One

Million BPD 0il Snale Industry................... 210 


\section{LIST OF F.IGURES}

Figure

Page

1. 0il Shale Plant Siting Methodology

2. Map of the Western Part of the United States Showing Counties with Potentially Developable Uil Shal,e

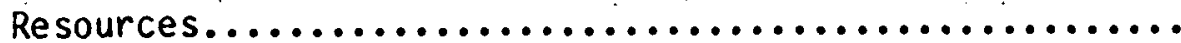

3. Map of the Eastern Part of the United States Showing Counties with Potentially Developable Ui.l. Snale

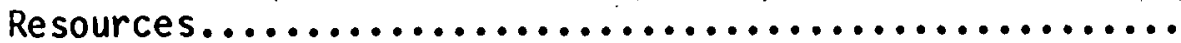




\section{SUPMARY}

The Western Research Institute plan for addressing oil snale plant siting methodology calls for identifying the available resources such as oil shale, water, topography and transportation, and human resources. Restrictions on development are addressed: 1and ownership, land use, water rights, environment, socioeconomics, culture, health and safety, and other institutional restrictions. Descriptions of the technologies for development of oil shale resources are included. The impacts of oil shale development on the environment, socioeconomic structure, water availability, and otner conditions are discussed. Finally, the Western Research Institute plan proposes to integrate these topics to develop a flow chart for oil shale plant siting.

Western Research Institute has (1) identified relative topics for shale oil plant siting, (2) surveyed both published and unpublished information, and (3) identified data gaps and research needs. 


\section{INTRODUCTION \\ by John Nordin}

Interest in U.S. oil shale development has increased and decreased over the past decades depending upon the price and availability of petroleum. The next resurgence in oil shale development will likely be in response to another impending petroleum supply crisis. Predicting the time and nature of such a crisis is nearly impossible because of the multitude of intangible factors which affect the determination. Currently (1987), the U.S. imports at least $40 \%$ of its petroleum. In addition, domestic petroleum reserves which can be economically ütilized are declining.

0il shale development was stimulated by the energy crises of 1973-74 and 1979 and reached major proportions before it cooled off in the 1980s. Industries assumed a number of risks outside their control, including inflation, interest rates, and energy costs. One lesson that developers learned was that the oil shale industry can not be assembled in a short time frame because of complex issues involving impacts on the environment, water rights, community development, and socioeconomic considerations.

Consequently, there are a number of topics that need to be addressed before developing an oil shale industry; these include, but are not limited to, the following:

1. define the available resources, which include not only oil shale but also water and human resources;

2. address restrictions on oil shale development, many of which are institutional, that involve land ownership and use, water rights, regulations protecting the cnvironment, and socioeconomic development;

3. define the technology best suited to recover shale oil and still comply with environmental and other restrictions; and

4. address and minimize environmental and other adverse consequences of oil shale development.

The WRI plan includes a literature review of the above topics and a brief discussion of their relevance to siting. Some of the review on restrictions is limited to a list of the laws or regulations with which the developer must comply. The next step is to identify information gaps and propose areas of research. Finally, eight topics are suggested for future research and a briet plan is developed for each.

In order to limit the scope of work, the following topics are not addressed in this plan: 
1. resources outside the U.S.;

2. future price and availability of petroleum;

3. uncertainties about inflation and interest rates;

4. possible litigation costs, insurance costs, and delays incurred as a result of development;

5. by-products and other uses of oil shale other than production of shale oil;

6. cost comparisons between alternative sites, different size plants, or alternate technologies but includes references where economic evaluations are given; and

7. 0 il shale processing technologies which have not been tested through pilot plant demonstration lexcept in the bibliographies). 


\section{COMPARISON OF WRI TO LOS ALAMUS OIL SHALE SITIMG METHODOLOGY RESEARCH}

The Los Alamos National Laboratory plan "A Strategic Plan for 0il Shale Siting Research" (Hinman 1986) was prepared for the U.S. Department of Energy as the result of a November 1985 strategic planning exercise on environmental research and policy to guide oil shale development. The participants in the exercise identified 13 strategic issues in four general categories: policy, source characterization and pollution generation, transport and impact, and risk assessment. For each issue, the participants defined an objective, identified a champion or expert, and made recommendations on how to conduct the research.

WRI will also categorize oil shale: siting topics into four categories: (1) resources, (2) restrictions on developing the resources, (3) process technology, and (4) impacts (Figure 1). This plan also includes a bibliography for each category and discusses its relevance to siting. The Los Alamos work does not evaluate prior research.

The Los Alamos plan developed 13 proad-based, subjective guidelines for environmental research. This plan concentrates more on information required for developers to site an oil shale plant and less on categories for research funding.

Finally, the WRI. plan proposes eight topics for continued study. The topics are fairly specific and overlap research proposed by Los Alamos that determines general policy direction, e.g., "What can be done to develop the understanding of surface and underground water systems in major oil shale basins?" WRI research is more specific, e.g., "How is the underground water system best protected during and following in situ and modified in situ development of oil shale?"

Reference: Hinman, G. S. Barr, E. J. Peterson, and M. D. Williams (Eds). "A Strategic Plan for Uil Snale Siting Research," Los Alamos National Laboratory, Los Alamos, NM, report LA-10767-MS, July 1986. 


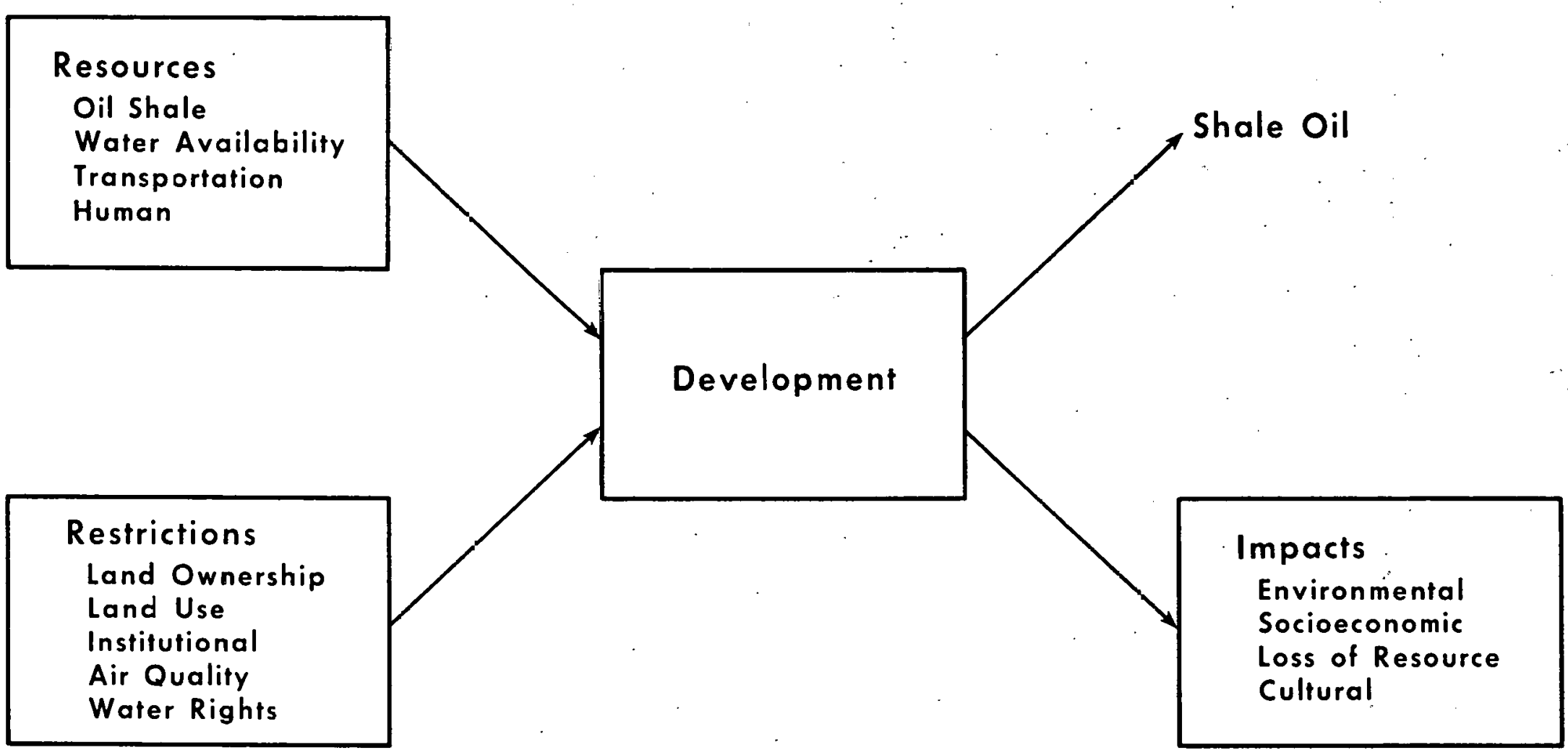

Figure 1. Shale Oil Plant Siting Methodology 
PHASE 1. RESOURCES 


\section{OIL SHALE RESOURCES \\ by Laurence Trude11}

This section discusses identification of oil shale resources that are suitable for development and are, therefore, potential locations for plant siting. Six types of deposit characteristics determine suitability for one or more development technology.

1. The size of an oil shale deposit determines its production potential and strongly influences such things as size of facilities, front-end financial requirements, construction lead time, and plant life. $0 i l$ shale reserves are usually expressed as in-place barrels of oil. Recovery rates depend on the design capacity of the processes employed.

2. The richness of the ore (i.e., the oil shale to be mined and processed) determines its economic attractiveness for development relative to other sources of liquid nydrocarbons.

3. The areal distribution of a deposit determines the maximum. size of mining operations, the number and distribution of sites that can be developed simultaneously or sequentially, and the ultimate magnitude of environmental and socioeconomic impacts. Simultaneous development of multiple sites can provide positive operational and economic advantages, e.g., increase in the size of the local labor pool, concentracton of anciliáry services, and distribution of utility and transportation expenses.

4. The geometry of a deposit (i.e.. thickness, depth, shape, incilination, and continuity) describes essential characteristics for determining its suitability for various mining and in situ technologies. Depth includes the depth from the ground surface to the top of the ore (overburden thickness) and the depth to the bottom of the ore (mining or in situ depth). Underground mining and modified in situ methods require relatively thick ore bodies, whereas true in situ methods are better suited to thin oil shale layers and are restricted to shallow depths. Surface (open pit) mining operations can be applied to very thick and deep deposits, but they must exceed a minimum thickness/overburden or richness/overburden ratio to be economically viable. Also, . predictable continuity is essential for in situ processes. Sometimes two or more oil shale zones suited to identical or different processes occur at different depths on a single site.

5. Physical characteristics can strongly influence a deposit's potential for development by a particular technology. For example, the physical strength of the shale partly determines the cost of mining, the shape and size distribution of the mine-run ore to be processed, and the 
requirements of pillars and walls for roof support. Natural fractures and cavities influence the uniformity and predictability of rock properties and the susceptibility of the formation to groundwater infiltration and leaching. The form and distribution of accessory constituents (e.g., saline minerals) can be important considerations in mining, retorting, and site abandonment strategies.

6. The mineral, organic, and trace element compositions of the ore and enclosing rocks are important for selecting retorting methods and identifying potential pollutants from development, processing, and site abandonment. Accessory materials (e.g., saline and aluminum minerals in some Green River oil shales) can yield either valuable by-products or troublesome pollutants, depending on whether they are left in the ground, recovered during processing, or discarded as waste. Layers containing undesirable constituents need to be identified and might be excluded from mining and processing.

All of these characteristics affect the determination of ' which oil shale deposits are suitable for one or more development technology. However, because so little shale oil has been commercially produced in the U.S., minimal or optimal requirements for the economic operation of various technologies have not been fully identified. In addition, new technologies and changing economics are likely to substantially alter the requirements.

In order to avoid the vagaries of future energy economics and process design, this plan proposes to define the minimum deposit characteristics for siting methodology in terms of physical and engineering constraints. A reserve's size requirement might be defined by the amount of ore necessary to sustain a minimum operation for a specified period of time. The minimum richness for any technology might be assumed to be the amount of organic material required to heat the enclosing oil shale to retorting temperature. Areal distribution is probably not a deterininant if the minimum reserve's size requirenent is met. Minimum thickness can probably be defined as the minimum required for true in situ processes. Maximum overburden thickness and mining depth may be determined by engineering criteria or by an overburden/oil-yield ratio.

For the purposes of this plan, limitations cannot be defined for shape, inclination, continuity, physical properties, or composition. But they would be defined as part of the proposed siting methodology to help identify potentially developable oil shale deposits. The following is an example of now these requirements might be presented. 
Table 1. Possible 0il Shale Deposit Requirements for Inclusion in the Siting Methodology Study

\begin{tabular}{lll}
\hline Reserves (in place) & $>$ & $100 \times 10^{6}$ bbl oil \\
Richness : & $>$ & $\begin{array}{l}10 \text { gallons oil per ton } \\
\text { or } 9 \text { wt. \% organic carbon }\end{array}$ \\
Uil snale thickness & $>$ & 10 feet \\
Overburden thickness & $<000$ feet \\
Mining or in situ depth & $<000$ feet \\
Overburden/oil-yield ratio & $<.0$
\end{tabular}

a Used only to determine the suitability of a deposit for openpit mining and calculated as follows:

Overburden/oil-yield ratio $=O /(R \times T)$

where $0=$ overburden thickness, in feet

$R=$ average richness, in gallons of oil per cubic foot of oil shale.

$T=$ thickiness of the ore zone, in fect.

(The O/RT for 10 feet of 10 gpt shale under 25 feet of overburden is 2.97.)

\section{CHARACTERIZING OIL SHALE RESUURCES}

Characterizing oil shale deposits requires measuring formation propertics at locations across the deposits. The preponderance of oil shale data for U.S. deposits comes from measurements on core samples, although other sampling and remote sensing methods are available for some properties. In oil shale formations where stratigraphic continuity has been confirmed by core analyses, as in must ul the Green River Formation and some parts of the eastern black shale deposits, the core data can be interpolated and extrapolated over large areas. In other stratigraphically and structurally complex formations (e.g.., the Elko Formation in Nevada and probably the northern Alaska oil shale deposits), dense coring patterns may be required for full characterization.

The most often applied method for measuring oil shale richness is the USBM Fischer Assay Procedure, ASTM designation: D 3904-80, which produces an empirical measure of shale oil, water, gas, and spent 
shale yields produced under specified retorting conditions. The Fischer assay was developed specifically for Green River oil shales; other methods have been proposed as more appropriate for eastern biack shales. In the U.S., oil yields have usually been reported in the English units, gallons per ton (gpt), and also in weight percent (wt \%). Where density/oil yield relationships have been established, richness can also be reported as gallons of shale oil per cubic foot of oil shale.

Resource size, distribution, thickness, depth, and geologic structure are compiled from core data and field studies by standard geological and statistical methods. Lithologic studies describe the breaking characteristics and accessory mineral content of resource formations, and they provide the descriptions for visual identification of stratigraphic and economic zones in mining operations. Physical properties (rock strength, permeability, porosity, and density) are usually measured on blocks and cylinders cut from large-diameter (3.5- to 7-inch) cores.

$X$-ray diffraction analysis is the most widely used method for characterizing the mineral composition of oil shales. This procedure measures the amount of the various crystalline mineral forms in the rock. Microscopic petrography is used to define mineral grain textures and interface relationships between mineral grains, organic matter, and pore spaces.

Chemical analysis of oil shale is performed by a variety of standard and special analytical procedures. Elemental and molecular compositions are determined for whole rock and for organic and mineral phases. Trace element analyses include determining the organic or mineral phase residence of the elements and partitioning the elements in process products.

The extent to which U.S. oil shale deposits have been characterized by these methods is not consistent. Usually, the extent of characterization corresponds to the perceived worth of the resource. The rich Green River oil shales of the Piceance Creek Basin in colorado are the most thoroughly sampled and analyzed in the country. A few hundred thousand samples from more than 250 core noles have been analyzed for richness, and mineral and chemical analyses have been performed on many samples. Green River oil shales in Utah and Wyoming have also been systematically analyzed, but characterization is not so complete. The characterization of the Devonian-Mississippian black shales of the eastern U.S. is also inconsistent. Areas of shallow black shale in Kentucky, Tennessee, Alabama, Indiana, and onio have been sampled and characterized, but the coverage is sparse. Almost no information is available for deeper deposits or for the Devonian-Mississippian oil shales in other states. Other oil snale deposits, such as the Elko Formation in Nevada and the Heath Formation in Montana, have been cored to provide preliminary resource assessments. And still others, like the oil shales of northern Alaska, have been spot sampled, but not systematically. A bibliography of publications on locations and characteristics of U.S. oil shale deposits are listed in Appendix $x$. 
A partial list of oil shale formations for which analyses have. indicated 10 feet of $10 \mathrm{gpt}$ shale appears in Table 2.

\section{Categorizing Deposits}

U.S. oil shale resources will be identified from the maps and tables published by Smith (1980), Duncan and Swanson (1965), and supplemental sources (Figure 1.1 .3 and Table 2). Deposits will be categorized according to their suitability for development. Some resources will require more research in order to determine their suitability for development. Types of development technologies include underground mining, surface mining, true in situ, vertical modified in situ, and horizontal modified in situ. Maps and tables will identify deposits that are suitable for the different technologies.

\section{Data Gaps and Research Meeds}

Information will De compiled on data gaps and research needs which prevent complete characterization, assessment, and categorization of oil shale deposits. These deficiencies will be prioritized according to their probable significance for developing oil snale resources. 
Table 2. 0il Snale Formations of the United States with Known Deposits More Than 10 Feet Thick and Yielding More . Than 10 Gallons of 0 il Per Ton (or 10 feet of shale containing more than 9 wt $q$ organic carbon).

\begin{tabular}{|c|c|c|c|c|}
\hline Formation & $\begin{array}{l}\text { Geologic } \\
\text { Age }\end{array}$ & State & County & References \\
\hline \multirow[t]{3}{*}{ Green River } & Tertiary & $\mathrm{CO}$ & $\begin{array}{l}\text { Garfield, Rio Blanco, } \\
\text { Mesa (possibly Moffat) }\end{array}$ & $\begin{array}{l}\text { Smith, Beard, and Trude } 111978 \text { and 1979; } \\
\text { Donnel1 1964; Pitman and Johnson 1978; } \\
\text { WRI 0il Shale Data Base }\end{array}$ \\
\hline & & UT & Uintah, Duchesne & $\begin{array}{l}\text { Trude } 11 \text { et al. 1983; Dana et al. 1980; } \\
\text { WRI 0il Snale Data Base }\end{array}$ \\
\hline & & 'NY & $\begin{array}{l}\text { Sweetwater, Uinta, Lincoln, } \\
\text { Sublette (possibly Carbon) }\end{array}$ & $\begin{array}{l}\text { Culbertson et al. 1980; Trudell et al. } \\
1973 \text {; Roehler 1969; Rocky Mountain Energy } \\
1980 \text { and 1981; WRI Oil Shale Data Base }\end{array}$ \\
\hline El ko & Tertiary & NV & El ko & $\begin{array}{l}\text { Moore et al. 1983; Server and Solomon } \\
\text { 1983; WRI Oil Shale Data Base }\end{array}$ \\
\hline $\begin{array}{l}\text { New Albany-Unio- } \\
\text { Sunbury- } \\
\text { Chattanooga }\end{array}$ & $\begin{array}{l}\text { Devonian- } \\
\text { Mississippian }\end{array}$ & KY & $\begin{array}{l}\text { Jefferson, Bullitt, Hardin, } \\
\text { Nelson, -arue, Marion, } \\
\text { Taylor, ddair, Metcalfe, } \\
\text { Russell, Pulaski, Casey, } \\
\text { Boyle, Lincoln, Rockcastle, } \\
\text { Garrard, Madison, Estill, } \\
\text { Clark, Powe11, Montgomery, } \\
\text { Bath, Rowan, Fleming, Lewis } \\
\text { (possibly Oidham, Barren, } \\
\text { Al len, Monroe, Cumberland, } \\
\text { Clinton, Jackson, Menifee) }\end{array}$ & $\begin{array}{l}\text { Janka and Dennison 1980; Kepferle, } \\
\text { Pollock, and Barron 1983; Barren et al. } \\
1982 \text { and 1985; Robl et al. } 1980 \text { and } 1981 \text {; } \\
\text { IMMR 1983; WRI Oil Shale Data Base }\end{array}$ \\
\hline $\begin{array}{l}\text { Onio- } \\
\text { Sunbury }\end{array}$ & $\begin{array}{l}\text { Devonian- } \\
\text { iMississippian }\end{array}$ & $\mathrm{OH}$ & $\begin{array}{l}\text { Adams, Sioioto, Pike, Ross, } \\
\text { Logan (possibly Pickaway) }\end{array}$ & $\begin{array}{l}\text { Janka and Dennison 1980; Conclin 1985; } \\
\text { METC 1981; WRI Uil Shale Data Base }\end{array}$ \\
\hline
\end{tabular}


Table 2 (Continued)

\begin{tabular}{|c|c|c|c|c|c|}
\hline Formation & $\begin{array}{l}\text { Geologic } \\
\text { Age }\end{array}$ & State & & County & Referenc $ə$ s. \\
\hline New Al Dany & $\begin{array}{l}\text { Devonian- } \\
\text { Mississippian }\end{array}$ & IN & & $\begin{array}{l}\text { Clark, Floyd, Scott, } \\
\text { Jackson } \\
\text { (possibly Jefferson, } \\
\text { Jennings, Eartnolomew) }\end{array}$ & $\begin{array}{l}\text { Janka and Dennison 1980; Bassett and } \\
\text { Hasenmueller 1979; Conciin 1985; } \\
\text { Hasenmueller 1981; WRI Uil Snale Data } \\
\text { Base }\end{array}$ \\
\hline Chattanooga & $\begin{array}{l}\text { Devonian- } \\
\text { Mississippian }\end{array}$ & TN & & $\begin{array}{l}\text { White, Putnam, Jackson, } \\
\text { Clay, Fentress, Cheatham, } \\
\text { Lincoln } \\
\text { (possibly Overton, DeKald, } \\
\text { Warren, Cannon, Davidson, } \\
\text { Sumner, Robertson, Moore, } \\
\text { Franklin) }\end{array}$ & $\begin{array}{l}\text { Janka and Dennison 1980; Rheams 1984; } \\
\text { Conant 19j1; WRI Oil Shale Data Base }\end{array}$ \\
\hline Cnattanooga & $\begin{array}{l}\text { Devonian- } \\
\text { Mississippian }\end{array}$ & AL & & $\begin{array}{l}\text { Morgan, Lawrence, Madison, } \\
\text { Jackson (possibly Limestone, } \\
\text { Cul Iman, Etiowah) }\end{array}$ & Rheams 1984; Janka and Dennison 1980 \\
\hline$?$ & $\begin{array}{l}\text { Devonian- } \\
\text { Mississippian }\end{array}$ & GA & & (possibly Chattanooga) & Janka and Dennison 1980 \\
\hline Antrim & $\begin{array}{l}\text { Devonian- } \\
\text { Mississippian }\end{array}$ & MI & - & $\begin{array}{l}\text { Cnarlevoix, Grand Traverse, } \\
\text { Kalkaska, Alcona, Manistee, } \\
\text { Missaukee, Roscommon, } \\
\text { Ogemaw, Midiand, Bay, } \\
\text { Tuscola, Sanilac, Saint } \\
\text { Clair, Clinton, Eaton, } \\
\text { Livingston, Wasntenaw } \\
\text { (possibly Antrim, Utego, } \\
\text { Montmorency, Alpena, Benzie, } \\
\text { Crawford, Oscoda, Wexford, } \\
\text { Iosco, Huron, Arenac, } \\
\text { Gladwin, Clare, Gratiot, } \\
\text { Saginaw, Sniawassee, } \\
\text { Genesee, Lapeer, Ingnam, } \\
\text { Oakland, Macomb, Jackson, Cass }\end{array}$ & Leffert arid Schroeder 1983 \\
\hline
\end{tabular}


Table 2 (Continued)

\begin{tabular}{lllll}
\hline Formation & $\begin{array}{c}\text { Geologic } \\
\text { Age }\end{array}$ & State & County & References \\
\hline $\begin{array}{l}\text { Woodford- } \\
\text { Chattanooga }\end{array}$ & $\begin{array}{l}\text { Devonian- } \\
\text { Mississippian }\end{array}$ & OK & $\begin{array}{l}\text { Murray } \\
\text { (possibly Pushmataha) }\end{array}$ & Janka and Dennison 1980 \\
$\begin{array}{l}\text { Barnett } \\
\text { Phosphoria }\end{array}$ & Permian & Possibly San Saba & Evans 1975 \\
Nation River & Upper Triassic & AK & $\begin{array}{l}\text { Fairbanks-Fort Yukon } \\
\text { District }\end{array}$ & Maughan 1983 \\
& Pennsylvania & KS & & Smith 1980; Duncan and Swanson 1965 \\
\end{tabular}




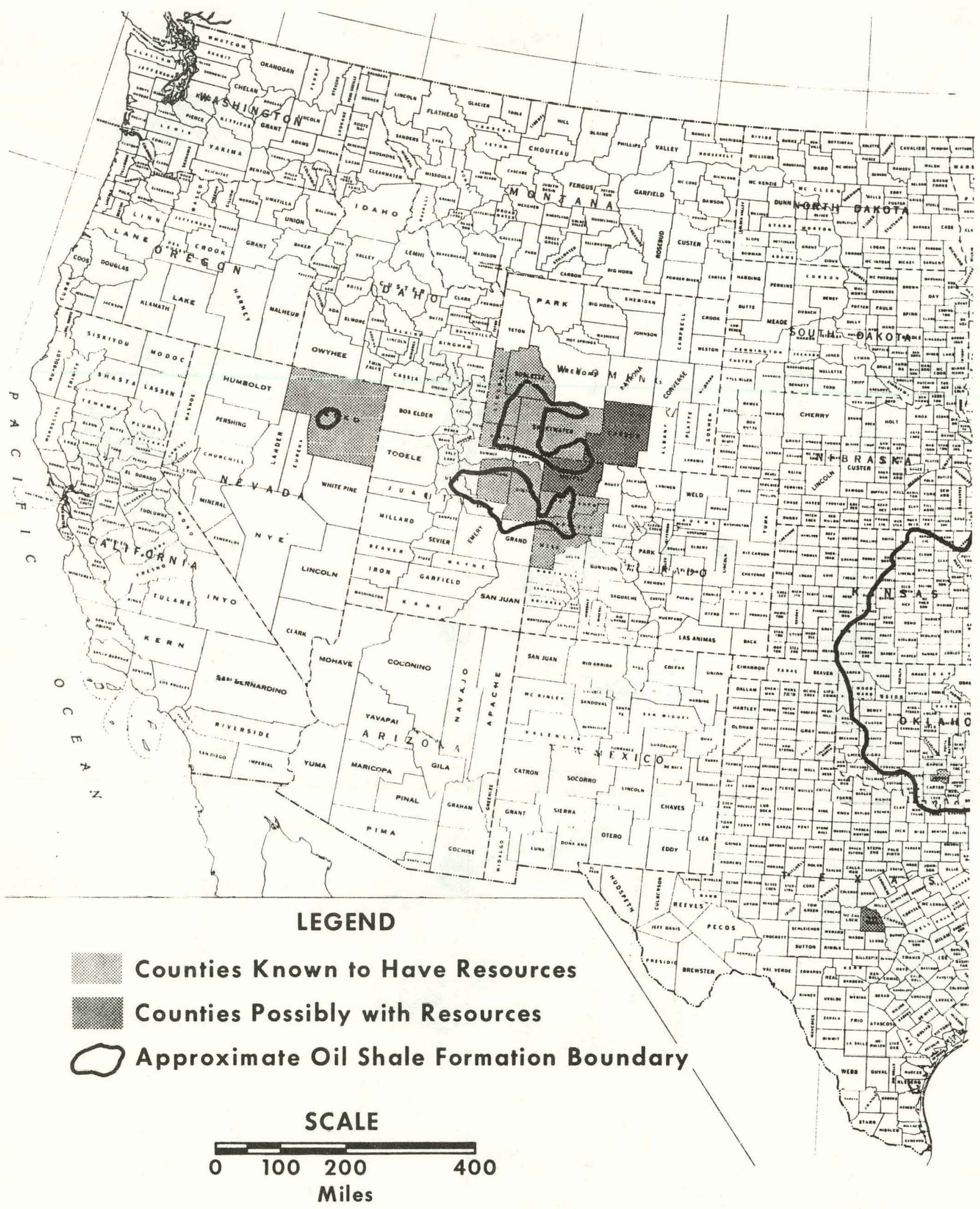

Figure 2. Map of the Western Part of the United States Showing Counties with Potentially Developable Oil Shale Resources 


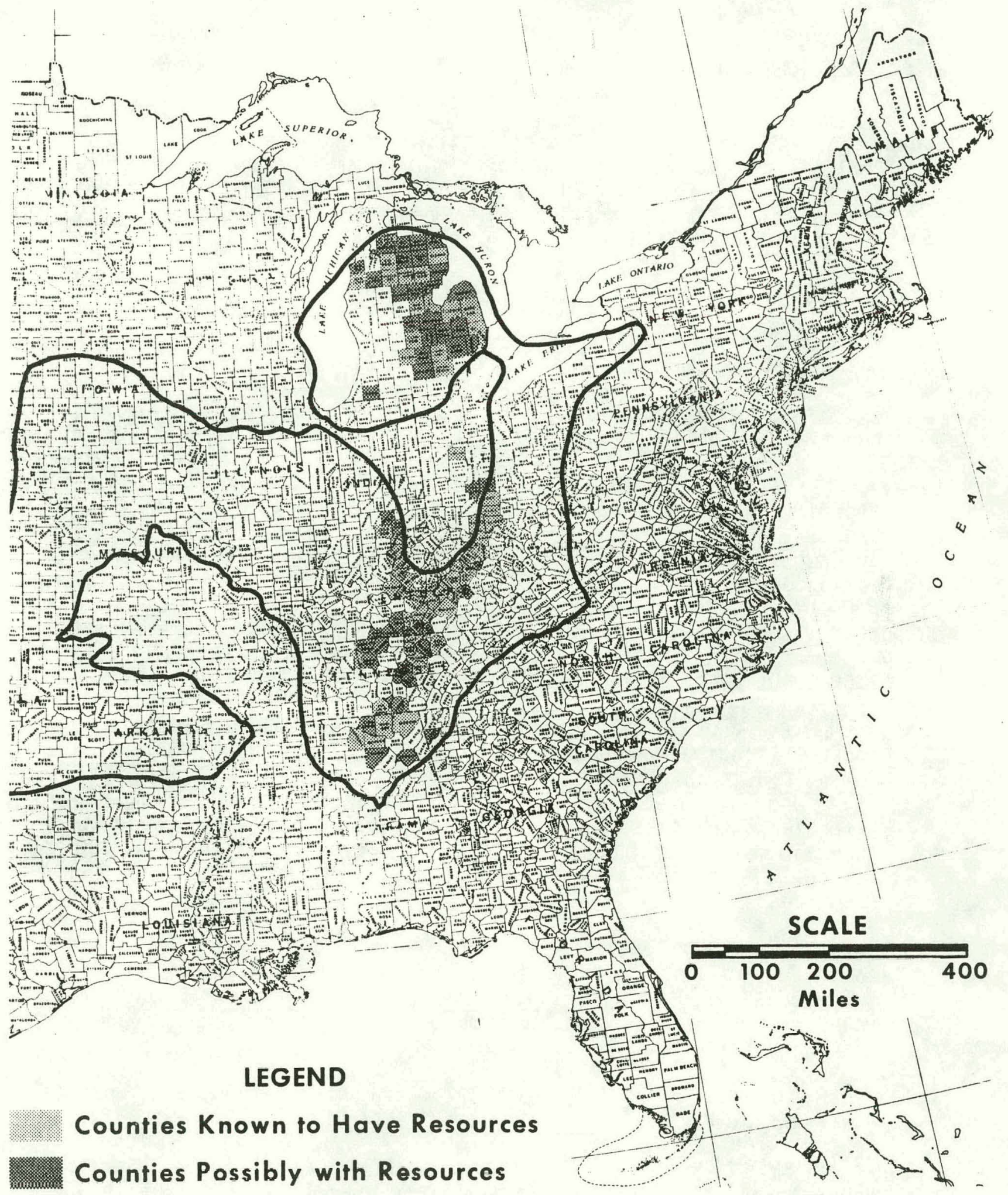

$\Longrightarrow$ Approximate Oil Shale Formation Boundary

Figure 3. Map of the Eastern Part of the United States Showing Counties with Potentially Dovelopable Oil Shale Resources 
BIBLIOGRAPHY FOR OIL SHALE RESOURCES OF THE UNITED STATES

Banks, C. E., and B. C. Franciscotti. "Resource Appraisal and Preliminary Planning for Surface Mining of Oil Shale, Piceance Creek Basin, Colorado," Proceedings of the 19th 0il Shale Symposium, Colorado School of Mines, Golden, CO, Colorado School of Mines Quarterly, 8(4), 1976, 257-259.

Barron, L. S., A. E. B1 and, T. L. Rob1, D. W. Koppenaa1, and G. A. Thomas. "Resource Assessment of the Uil Shales of Northeastern Kentucky," Symposium Papers Synthetic Fuels from 0il Shale II, Nashville, TN, Inst. Gas Tech., 1982, 43-71.

[Resource assessment. hased on 10 cores from Lewis and Fleming counties. Fig. $4-10 \mathrm{gpt}=\sim 8-9$ wt \% C]

Barron, L. S., L. R. Robl, J. Kung, and J. Ubley. "DevonianMississippian 0il Shale Resources of Kentucky: A Summary," Proceedings of the 1984 Eastern 0il Shale Symposium, University of Kentucky Institute for Mining and MineraTs Research, Lexington, $\mathrm{KY}, 1985,347-364$.

Bassett, J. L., and N. R. Hasenmueller. "Map Showing Structure on Top of New Albany Shale and Equivalent Strata in Indiana," scale 1:500,000, Dept. of Energy EGSP series no. 801, 1979.

r.nnant. L. C., and V. E. Swanson. "Chattanooga Shale and Related Rocks of Central Tennessee and Nearby Arcas," U.S. Genlngical Survey Prof. Paper, 357, 1961.

[Excellent treatise on the Chattanooga Shale. Very good map showing the distribution of Devonian marine sediments in the United States. Not much information on oil shale richness and resources.]

Conclin, J. E. "I atee Devonian New Albany-Onio-Chattanooga Shales and Their Interbasinal Correlation in Indiana, unio, Kentucky and Tennessee," Proceedings of the 1985 Eastern 0il Shale Symposium, University of Kentucky Institute for Mining and Minerals Research, Lexington, KY, 1985, 217-260.

Culbertson, W. C. "0il Shale In The Green River Formation, Green River Basin, Wyoming," Mountain Geologist, $8(2,3), 1972,183-187$.

Culbertson, W. C., and J. K. Pitman. "0il Shale," United States Mineral Resources, U.S. Geological Survey Prof. Paper, 820, 1973, 497-503.

Culbertson, W. C., J. W. Smith, and L. G. Trudell. "0il Shale Resources and Geology of the Green River Formation in the Green River Basin, Wyoming," DOE report of investigation LETC/RI-80/6, 1980. 
[Stratigraphic framework and partial resource assessment of oil shales in the Green River Basin.]

Dana, G. F., J. W. Smith, and L. G. Trudell. "Shallow Uil Shale Resources of the Southern Uinta Basin, Utan," DOE report of investigation LETC/RI-80/11, 1980.

[Resource evaluation of relatively thin oil shale sections with less than 200 feet overburden in the southern and southeastern parts of the Uinta Basin.]

Derky, P. D., F. N. Abercrombie, S. M. Vuke, and J. A. Daniel. "Geology and Resources of the Heath Formation, Fergus County, Montana," Montana Bureau of Mines and Geology Memoir, 57, Butte, MT, 1985.

[Resource assessment based on 8 core noles.]

Dillman, L. B., and F. R. Ellensohn. "Isopach Map of the Devonian Black Shale Sequence in Eastern Kentucky," METC/EBSP series no. 515, Morgantown, WV, 1980.

Donnel1, J. R. "Geology and Oil Shale Resources of the Green River Formation," Proceedings of the First 0il Shale Symposium, Golden, CO, Colorado School of Mines Quarter7y, 59(3), 1964, 153-163.

Duncan, D. C., and V. A. Swanson. "Organic-Rich Shale of the United States and World Areas," U.S. Geological Survey Circ., 523, 1965.

[Map and very general discussion of oil shale formations of the United States.j

Dutta, P. K., and N. R. Hasenmueller. "Thickness and Nature of Overburden on the New Albany Shale in Southeastern Indiana," Proceedings of the 1982 Eastern 0il Shale Symposium, Lexington, KY, 1983, 119-126.

[Provides only data on overburden less than 150 feet thick in Clark, Scott, and Jackson counties, at southeast end of Devonian outcrop in Indiana.]

Evans, T. J. "Native Bituminous Materials in Texas," Mineral Resource Circular, no. 57, Texas Bureau of Economic Geology, Austin, TX, 1975, 11-16.

Grissnn, M. C. "Oil Shạle and Tar Sands: A Bibliography," DOE technical information circular DUE/TIC-3367, 1981.

Hasenmueller, N. R. "Resource Assessment of the New Albany Shale in Southeastern Indiana--Preliminary Report," Proceedings of the Kentucky 1981 Eastern 0il Shale Symposium, Lexington, KY, Lemticly Dept. of Energy and the University of Kentucky Institute for Mining and Minerals Research, 1982, 173-180. 
[Evaluation of near-surface deposits in Clark, Scott, and Jackson counties. Good geologic map showing New Albany Shale and equivalent in Indiana. Typical organic carbon profiles for two core noles.]

Hasenmueller, N. R. "Distribution, Thickness, Lithology and Geochemistry of the New Albany Shale in Southeastern Indiana," in N. R. Hasenmueller and G. S. Woodard, eds., Studies of the $\overline{\text { New }}$ Albany Shale and Equivalent Strat in Indiana, Indiana Geological Survey, Bloomington, IN, 1981.

Hendrickson, T. A. "011 Snale Processing Metnods," Proceedings of the 7 th 0 il Shale Symposium, Golden, CO, Colorado School of Mines Quarter7y, $69(2), 1974,45-69$.

Humphrey, G. P., and J. B. Damukaitis. "Commercialization of Eastern Uil Shale," Proceedings of the 1982 Eastern Uil Shale Symposium, University of Kentucky Instftute for Mining and Minerals Research, Lexington, KY, 1983, 219-225.

Janka, J. C., and J. M. Dennison. "Devonian 0il Snale, A Major American Energy Resource," Proceedings Symposium on Syntnetics Fuels from Uil Shale, Chicago, IL, Inst. Gas Tech., 1980, 25-116.

[This is the best single paper on Devonian-inississippian oil shale resources. General discussion of geographic distribution, stratigraphy, paleogeography, environments of deposition, and analytical techniques. Good state-by-state discussion of deposits and resources; good state maps showing outcrops and areas underlain by Dev.-Miss. shales.]

Kepferle, R. C., and R. D. Matthews. "Field Trip Guidebook, Uil Snale and Tar Sands of Kentucky," Inst. Gas Tech. Symposium and Field Trip, Louisville, KY, May 17-20, 1983.

Kepferle, R. C., J. D. Pollock, and L. S. Barron. "Stratigraphy of the Devonian and Mississippian 0il Bearing Shales of Central Kentucky," Proceedings of the 1982 Eastern 0il Snale Symposium, University of Kentucky Institute for Mining and Minerals Research, Lexington, KY, 1983, 137-149.

[Good description and map of shallow deposits in Kentucky.]

Leffert, C. B., and R. K. Schroeder. "Fischer Assay Analyses of the Antrim Dil Shale of the Michigan Basin," DOE topical report FE2346-83, 1983.

[Fischer assay oil yields of arill cutting samples from 36 wells and grab samples from 9 outcrops of Antrim Shale from 25 counties throughout lower Michigan.]

Lindquist, E. D., and G. D. Ano. "A Comparison of Various Aspects of Mining Oil Shale in the Western and Eastern United States," Proceedings of the 1981 Eastern 0il Snale Symposium, Lexington, 
KY, Kentucky Dept. of Energy and the University of Kentucky Institute for Mining and Minerals Research, 1982, 39-41.

[Gives dimensions of some proposed western and eastern mines, including overburden. Minimum thickness mentioned for underground mining is 15 feet.]

Lineback, J. A. "Coordination of Study of Devonian Black Shale in the Illinois Basin," Quarterly Progress Report, Feb. 1-May 31, 1985, NTIS PC A03/MF AOT(FE--8214-T2), 1985.

Maughan, E. K. "Geological Setting and Geochemistry of 0il Shales in the Permian Phosphoria Formation," in Geochemistry and Chemistry of 0il Shales, American Chem. Soc., Washington, D.C., 1983, 199224.

Moore, S. W., H. B. Madrid, and G. T. Server, Jr. "Results of dil Shale Investigation in Northeastern Nevada," U.S. Geological Survey open file report 83-586, 1983.

[Resource assessment of the Elko Formation based on 6 core holes.]

Morgantown Energy Technology Center. "Feasibility of Establishing and Operating a Generic 0il Shale Test Facility," DOE report DOE/METC-86/6046 (DE86006591), December 1986.

[Suminary of oil shale resources of the United States]

Morgantown Energy Technology Center. "Evaluation of Devonian Shale Potential in Onio," DOE report DUE/METC-122, 1981.

National Academy of Sciences. "Resources, Reserves, Production, and Related Requirements for Uil Shale," CONAES, Uil Shale Subpanal, Washington, D.C., Revised Draft, Feb. 22, 1977.

Pitman, J. K., and R. C. Johnson. "Isopach, Structural Contour, and Resource Maps of the Mahogany 0il-Snale Zone, Green River Formation, Piceance Creek Basin, Colorado," U.S. Geological Survey misc. field studies, map 958, 1978.

Pollock, D., L. Barron, and J. Beard. "Stratigraphy and Resource Assessment of the 0il Shales of East Central Kentucky," Proceedings of the 1981 Eastern 0il Shale Symposium, University of Kentucky, Institute for Mining and Minerals Research, Lexington, $K Y, 1982,195-212$.

[Evaluation of shallow deposits in Rowan, Bath, Montgomery, Powell, and Estill counties based on 11 core holes. This report uses $8 \%$ organic carbon as the cutoff for strip mining resources.]

Rheams, K. F,, and T. L. Neatherly. "Characterization of the 0i1Bearing Devonian Chattanooga Shale, North Alabama and SouthCentral Tennessee," Geological Society of America, Southeast 
Section 33rd Annual Meeting, GSA, 2nd Abstracts, 16(3), February 1984.

Robl, T. L. "Resource Assessment of 0il Bearing Shales in Lewis and Flening Counties, Kentucky," Volumes I and II, Unjiversity of Kentucky, Institute for Mining and Mineral Research technical reports IMMR80/D-19/2a and IMMR80/D-19, 1980 and 1981.

Rocky Mountain Energy. "Land Grant Evaluation Program on 0il Snale in the Green River and Washakie Basins, Wyoming, 1980-1981," Broomfield, CU, unpublished company report.

[This unpublished two-volume looseleaf report was provided to LETC in 1982 with authorization to use the data as we see fit. It contalns yood resuurce, distribution, richness, thickness, and overburden data for the southeastern Green River Basin and the northwestern Washakie Basin, including unpublished data from a number of RMEC shallow core holes.]

Roenler, H. W. "Stratigraphy and 0il Shale Deposits of Eocene Rocks in the Washakie Basin, Wyoming," Wyoming Geological Association Guidebook, Symposium on Tertiary Rocks, Casper, WY, 1969, 197206.

Rube 1, A. M., D. W. Koppenaal, D. N. Taulbee, and T. L. Robl. "Chemical Aspects of Eastern 0il Shale Retorting: Analysis of a Core," Proceedings of the 16th 0il Shale Symposium, Colorado School of Mines, Golden, C0, 1983, 132-143.

[Gives carbon/oil yield relationship determined from one core hole in Madison in., Kentucky. Shows $10 \mathrm{gpt}=9 \mathrm{wt} \% \mathrm{C}$.

Scnlinsog, D. G., and E. E. Angino. "Potential Uil Recovery from Kansas 0il Shale," Kansas Geological Survey, Energy Resources Series, 22, 1983.

[0il yields and stratigrapnic information for a number of organic-rich shales in Kansas. Limited number of sampled sections.]

Server, G. T., Jr., and B. J. Solomon. "Geology and 0il Snale Deposits of the Elko Formation in the Pine Range, Nevada," U.S. Geological Survery misc. field studies, map MF-1546, 1983.

Shaffer, N. R., R. K. Leiniger, and M. V. Ennis. "Uil Shale of Pennsylvanian Age in Indiana,". Proceedings of the 1984 Eastern 0i1 Shale Symposium, University of Kentucky, Institute for Mining and Minera1s Research, Lexington, KY, 1984, 401-412.

Shaffer, N. R., R. K. Leiniger, and M. V. Ennis. "Comparison of Organic-Rich Shales of Pennsylvanian Age in Indiana with New Albany Snale," AAPG Bul1., 67(9), 1983, 1459-1460. 
Shin, C. C., J. E. Cotter, C. H. Prien, and T. D. Nevens. "Technical Overview Reports for Eight Shale Uil Recovery Processes," EPA report, EPA-600/7-79-075, 1979.

Sladek, T. A. "Recent Trends in 0il Shale--Part 2: Mining and Shale 0i1 Extraction Processes," Colorado School of Mines Research Institute, Mineral Industries Bulletin, 18(2), 1975.

Smith, J. W. "Oil Shale Resources of the United States," Colorado School of Mines, Golden, CO, Mineral and Energy Resources Series, 23, 1980.

[General discussions, maps, and tables on organic-rich shales of the United States.]

Smith, J. W., T. N. Beard, and L. G. Trude11. "Colorado's Primary 0il Shale Resource for Vertical Modified In Situ Processes," DUE report of investigation LETC/RI-78/2, 1978.

[Comprenensive resource evaluation for the Mahogany zone and overlying oil shale for the entire Piceance Creek Basin. No information on the deeper oil shales.]

Smith, J. W., T. N. Beard, and L. G. Trudell. "0il Shale Resources of Naval Oil Shale Reserve No. 1, Colorado," DUE report of investigation LETC/RI-79/2, 1979.

[Comprehensive resource evaluation for the $R-6$, the Mahogany zone, and overlying oil shales in the southeastern corner of the Piceance Creek Basin.]

Trude11, L. G., H. W. Roehler, and J. W. Smith. "Geology of Eocene Rocks and 0il Yields of Green River 0il Shales on Part of Kinney Rim, Washakie Basin, Wyoming," U.S. Bureau of Mines Report of Investigation, $\mathrm{RI}-7775,1973$.

[Resource assessment. for the west-central part of the Washakie Basin based on three core noles.]

Trude11, L. G., J. W. Smith, T. N. Beard, and G. M. Mason. "Primary 0il Shale Resources of the Green River Formation in the Eastern Uinta Basin, Utan," DUE report of investigation DUE/LC/RI-82-4, 1983.

[Comprehensive evaluation of oil shales east of the Green River in Utah.]

University of Kentucky, Institute for Mining and Minerals Research. "The Commercial Feasibility of Mississippian and Devonian 0i1 Shales of Kentucky," Lexington, KY, IMMR 83/081, April 1983.

Vyas, K. C., G. D. Aho, and T. L. Rob 1. "Synthetic Fuels from Eastern 0il Snales," Final Report Project NC-5477, University of Kentucky, Institute for Mining and Minerals Research, Lexington, $K Y$, DUE report DOE/R4/10185-T1, 1981. 
Western Research Institute. "0il Shale Data Base," computer tapes and files of information on richness, mineralogy, stratigraphy, and lithology of oil shales of the United States; unpublished data.

[Files of richness, lithology, and mineral data from 530 core noles in Colorado, Utah, and Wyoming. Limited data on other oil shale formations in Alabama, Alaska, Arkansas, Idaho, Illinois, Indiana, Kansas, Kentucky, Michigan, Montana, Nevada, Unio, Oregon, South Dakota, Tennessee, Texas, Utah, Vermont, Virginia, West Virginia, Wisconsin, and Wyoming.]

Zielinski, R. "Resource Recovery from the Devonian Shales of the Appalachian Basin," Proceedings of the 1983 Eastern Uil Shale Symposium, Lexington, KY, University of Kentucky Institute for Mining and Minerals Kesearch and the Kencucky Energy Cabiluel, $1983,27-34$.

[General discussion of oil yields and other characteristics of black shales in eastern Kentucky, West Virginia, Onio, Pennsylvania, and New York. Sparse, indirect sampling.] 


\section{HATER AVAILABILITY by Robert Donovan}

Water is a crucial resource for western oil shale development. The availability of suitable water is dependent upon the nydrologic resources of the site and the consumptive requirements of the oil shale technology. Water laws and land use laws can also limit water availability. Research on Colorado, Wyoming, and Utan water supplies for synfuels development is far greater than that of other oil shale regions.

Three technologies (true in situ, modified in situ, and surface retorting) and their respective water budgets will be discussed. In addition to surface water and groundwater, groundwater mining and prospective a'nd current surface water impoundment structures contribute to water availability. Water resources of the major eastern oil shale region (the Knobs area of Kentucky) and three western oil shale states (Colorado, Wyoming, and Utah) are discussed below.

\section{Water Budgets}

Water is needed at an oil shale processing plant for drilling, inining, crushing, retorting, shale oil upgrading, power plant requirements, revegetation, dust control, and support building operations. However, the amount of water consuned varies greatiy depending on the retorting process used and the extent of shale oil upgrading. For example, the modified and true in situ retorting processes usually require less water than surface retorting.

True in situ retorting, as well as modified in situ retorting, does not require the extensive mining, crushing, wetting of hot spent shale, dust control of spent or raw shale fines, and revegetation that surface retorting requires. In addition, the vicinity of in situ retorting chambers must be dewatered, which generally adds a net surplus to the water budget. Dewatering causes the piezometric surface to depress and eventually lower below mining or combustion levels. This withdrawn water can be used for a variety of purposes, including shale disposal, revegetation, construction use, dust control, ventilation control, potable water, and supplementary municipal use. However, dewatering of the mining or retorting site will also lower stream and spring discharges in the vicinity. For this reason, excess water from mine dewatering will likely be used to correct for this loss.

Surface retorting requires more water than in situ retorting. For this reason, nost plans for surface retorting have water need projections that are closely matched to water availability estimates that include dewatering. Some proposed surface retorting schemes do require supplemental water from inpoundment structures le.g., the White River Shale Project, proposed for Federal Uil Shale Lease tracts $U-a$ and $U-D$, plans on damming the White River in northwestern Colorado). 
Water balance figures for proposed oil shale retorting projects are presented in Table 3. With one exception, the water availability/consumption figures were extracted from detailed development plans and environmental impact statements for western oil shale reserves. It should be emphasized that less arid eastern oil shale regions may yield large surpluses of water because of mine dewatering when compared to western deposits.

\section{Western oil Shale Water Resources}

Currently, surface water resources of the Upper Colorado River Basin are used primarily for agriculture. There are over 30 diversion projects within this drainage basin, and most are used to maintain flows so that states can consume the maximum amount of water and still regulate outputs. Over 34 milliun acre feet of water dre Impourcued by the Colorado River Storage Project (CRSP). Future non-synfuels related depletions of the water storage in the Upper Colorado River Basin are expected to come primarily from agriculture. Agriculture will account for $60 \%$ of total depletions in the year 2000 , followed by municipal and industrial use and thermoelectric power (Water Resources Council 1981).

The average annual natural flow of major rivers in the western oil shale resource area are presented in Table 3. Unless otherwise indicated, flows are measured at outflow points on the rivers.

Table 3. Average Annual Flows and Depletions, Upper Colorado River Basin (Water Resources Council, 1981)

\begin{tabular}{ccc}
\hline River & $\begin{array}{c}\text { Current } \\
\text { Average Annual } \\
\text { Flows }\end{array}$ & $\begin{array}{c}\text { Current } \\
\text { Average Annual } \\
\text { Depletions } \\
\text { (in million acre-feet) } \\
\text { (in million acre-feet) }\end{array}$ \\
\hline $\begin{array}{l}\text { Upper Green River } \\
\text { Yampa River }\end{array}$ & 2 & .317 \\
$\begin{array}{l}\text { White River } \\
\text { Upper Colorado } \\
\text { main stem }\end{array}$ & 1.7 & .114 \\
Lower Green River & .568 & .047 \\
\hline
\end{tabular}

Little research has been conducted to estimate the quantity of groundwater in the Piceance Creek Basin. The Water Resources Council 
(1981) estimated a total groundwater volume between from 2.5 and 25 million acre feet with an annual recharge of 23,000 to 29,000 acre feet per year. Lindskov and Kimball (1984) performed a much more detailed study of the Uinta Basin $0 i 1$ shale region's water resources. They calculated the Basin's total volume of groundwater to be 18.1 million acre feet, the majority of which is in the Douglas Creek Aquifer of the Green River Formation (16 million acre feet), followed by the Bird's Nest Aquifer of the Green River Formation (1.9 million acre feet). Alluvial deposits in the Basin are estimated to contain the remaining 200,000 acre feet. of this total estimated volume of 18.1 million acre feet, 21,000 acre feet per year are available for oil shale processing from the Douglas Creek and Bird's Nest Aquifers (Lindskov and Kimball). This amount of withdrawal, nowever, would result in depleted stream flows in the region as well as a possible reduction in stock-watering wells.

The majority of research on oil shale siting in the eastern U.S. has been conducted in the Knobs region of Kentucky. Because this region receives between 40 and 50 inches of rain annually, water availability is seldom considered for eastern oil shale development.

The most accessible oil shale in Kentucky lies within the network of six drainage systems: the Onio, Kentucky, Licking, Red, Salt, and Rolling Fork Rivers. The Onio and Kentucky Rivers each can supply enough water to operate inultiple processing sites (Van Arsdall and. Twilley 1983). Other rivers in the region also are capable of supplying large amounts of water for processing oil shale, given developments such as impoundment structures, ditch diversions, and pipelines. The average flows of major rivers in the knobs region are presented in Table 4.

Table 4. Average Flows of Major Rivers in Knobs Region of Kentucky

\begin{tabular}{lcc} 
River & $\begin{array}{c}\text { Total Orainage } \\
\text { Area }(\mathrm{sq} \mathrm{mi})\end{array}$ & $\begin{array}{c}\text { Average flow } \\
\text { in Knobs Region } \\
\text { (cubic feet per second) }\end{array}$ \\
\hline Onio & 91,000 & 116,000 \\
Licking & 827 & 1,070 \\
Kentucky & 2,657 & 3,667 \\
Salt & 1,197 & 1,599 \\
\hline
\end{tabular}


Groundwater availability in the knobs region has not been quantified for purposes of energy development. However, Van Arsdall and. Twilley (1983) and Mitsch and Lind (1982) concluded that groundwater in the area is generally insufficient to accommodate a developing or pilot scale oil shale processing site. Major, nign yield aquifers are absent in the region, and wells that currently produce up to 500 gallons per day are restricted to alluvial deposits in valley bottoms of major rivers. 
Table 5. Water Availability and Estimates for Proposed Oil Snale Processing Projects

\begin{tabular}{|c|c|c|c|c|c|c|}
\hline Reference & $\begin{array}{l}\text { Location and } \\
\text { Process }\end{array}$ & $\begin{array}{l}\text { Snale 0il } \\
\text { Production }\end{array}$ & $\begin{array}{l}\text { Water } \\
\text { Source }\end{array}$ & $\begin{array}{l}\text { Amount } \\
\text { Available }\end{array}$ & $\begin{array}{c}\text { Water } \\
\text { Consumption }\end{array}$ & $\begin{array}{l}\text { Excess } \\
\text { Water }\end{array}$ \\
\hline $\begin{array}{l}\text { Tipton and } \\
\text { Kalmbach, } \\
\text { Inc. } 1977\end{array}$ & $\begin{array}{l}\text { Ficeance } \\
\text { Creek Basin, } \\
\text { MIS }\end{array}$ & $\begin{array}{l}57,000 \\
\mathrm{bb} 1 / \text { day }\end{array}$ & $\begin{array}{l}\text { mine } \\
\text { dewatering }\end{array}$ & $\begin{array}{l}4000- \\
10,000 \\
g \mathrm{pm}\end{array}$ & $\begin{array}{l}1250 \\
\text { gpm }\end{array}$ & $\begin{array}{l}2750- \\
8750 \\
\text { gpm }\end{array}$ \\
\hline $\begin{array}{l}\text { Lloyd } \\
1983\end{array}$ & $\begin{array}{l}\text { kentucky } \\
\text { cpen pit with } \\
\text { surface retort }\end{array}$ & $\begin{array}{l}50,000 \\
\text { bb } 1 / \text { day }\end{array}$ & $\begin{array}{l}\text { mine } \\
\text { dewatering } \\
\text { or surface }\end{array}$ & $\begin{array}{l}\text { not } \\
\text { defined }\end{array}$ & $\begin{array}{l}5300 \\
\mathrm{gpm}\end{array}$ & -- \\
\hline $\begin{array}{l}\text { Jee } \\
\text { et a1. } 1977\end{array}$ & $\begin{array}{l}\text { True } \\
\text { in-situ }\end{array}$ & $\begin{array}{l}64,000 \\
\text { bb 1/day }\end{array}$ & $\begin{array}{l}\text { mine } \\
\text { dewatering }\end{array}$ & $\begin{array}{l}\text { not } \\
\text { defined }\end{array}$ & $\begin{array}{l}24.8 \\
\mathrm{gpm}\end{array}$ & -- \\
\hline $\begin{array}{l}\text { Environmental } \\
\text { Impact Stmnt } \\
\text { US DUE } 1985\end{array}$ & $\begin{array}{l}\text { Piceance } \\
\text { Creek Basin } \\
\text { open pit with } \\
\text { surface retort }\end{array}$ & $\begin{array}{l}100,000 \\
\text { bbl/day }\end{array}$ & $\begin{array}{l}\text { mine } \\
\text { dewatering } \\
\text { and dam on } \\
\text { White River }\end{array}$ & $\begin{array}{l}8900 \\
\mathrm{gpm}\end{array}$ & $\begin{array}{l}8900 \\
\mathrm{gpm}\end{array}$ & 0 \\
\hline $\begin{array}{l}\text { Rio Blanco } \\
\text { Uil Shale } \\
\text { Project } 1977\end{array}$ & $\begin{array}{l}\text { Piceance } \\
\text { Creek Basin } \\
\text { iract C-a, MIS }\end{array}$ & $\begin{array}{l}76,000 \\
\text { bD 1/day }\end{array}$ & $\begin{array}{l}\text { mine } \\
\text { dewatering }\end{array}$ & $\begin{array}{l}2300 \\
\mathrm{gpm}\end{array}$ & $\begin{array}{l}1400 \\
\mathrm{gpm}\end{array}$ & $\begin{array}{l}9000 \\
\text { gpm }\end{array}$ \\
\hline $\begin{array}{l}\text { Mehran } \\
1981\end{array}$ & $\begin{array}{l}\text { Piceance } \\
\text { Creek Basin }\end{array}$ & $\begin{array}{l}50,000 \\
\text { Db 1/day }\end{array}$ & $\begin{array}{l}\text { mine } \\
\text { dewatering }\end{array}$ & $\begin{array}{l}14,200 \\
\text { gpm }\end{array}$ & $\begin{array}{l}9800 \\
\text { gpm }\end{array}$ & $\begin{array}{l}1400 \\
g p m\end{array}$ \\
\hline $\begin{array}{l}\text { Mckee and } \\
\text { Kunchal } \\
1976\end{array}$ & $\begin{array}{l}\text { Paraho Process } \\
\text { experimental }\end{array}$ & $\begin{array}{l}100,000 \\
\mathrm{bb} 1 / \text { day }\end{array}$ & $\begin{array}{l}\text { not } \\
\text { defined }\end{array}$ & $\begin{array}{l}\text { not } \\
\text { defined }\end{array}$ & $\begin{array}{l}6200 \\
\text { gpm }\end{array}$ & -- \\
\hline $\begin{array}{l}\text { White River } \\
\text { Shale Project } \\
\text { Detailed } \\
\text { Develapment } \\
\text { Plan }\end{array}$ & $\begin{array}{l}\text { Uinta Basin } \\
\text { Colorado and } \\
\text { Utan, room- } \\
\text { and-pillar } \\
\text { mining }\end{array}$ & $\begin{array}{l}100,000 \\
\text { bbl/day }\end{array}$ & $\begin{array}{l}\text { dam and } \\
\text { reservoir } \\
\text { on the White } \\
\text { River, mine } \\
\text { dewatering }\end{array}$ & $\begin{array}{l}\text { not } \\
\text { defined }\end{array}$ & $\begin{array}{l}8000 \\
\text { gpm }\end{array}$ & -- \\
\hline
\end{tabular}




\section{BIBLIOGRAPHY FOR OIL SHALE MATER RESOURCES}

Adams, D. B., D. P. Bauer, R. H. Dale, and T. D. Steele. "Resource Development Impacts on Surface Quality and Quantity in Yampa Basin, Colorado and Wyoming," U.S. Geological Survey Water Resources Investigation, 1982, no. 81-30.

Alley, W. M. "Relative Importance of Groundwater and Surface Water Supplies to 0il Shale Development, Piceance Basin, Colorado," U. S. Geological Survey Open File Report, 1982, no. 82-0340.

Banks, C. E., W. S. Bradley, B. C. Franciscotti, and J. L. Huckelbury. "Simulated Dewatering Requirements at an vil Snale Surface Mine, Piceance Basin," Colorado School of Mincs, Mineral Ind. Bul1., 1978, 21(2).

Boettcher, A. J. "Groundwater Occurrence in Northern and Central Parts of Western. Colorado," Colorado Water Conservation Board Water Res. Circ., 1972, no. 15.

Butler, D. L. "Spring Flow Monitoring, Parachute Creek and Roan Creek Drainage Basins," U.S. Geological Survey Open File Report, 1981, no. $81-150$.

Cathedral Bluffs Shale 0il Company. "Environmental Monitoring Plan Outline," Grand Junction, CU, March 19, 1984.

Cathedral Bluffs Shale 0il Company. "Summary of Development Activities, Costs, and Environmental Monitoring - 1985," Grand Junction, CU, April 30, 1986.

Cathedral Bluffs Snale Uil Company - Tenneco Shale 0il Company. "CD Annual Reports - Environmental Analysis, 1979, 1980, 1981, 1982," Grand Junction, CO.

Cathedral Bluffs Shale 0il Project - Ashland 0i1, Inc. - Arco Shell. "Tract CD Summary Report No. 1," Denver, CO, February 10, 1975, Quarterly Report.

Cathedral Bluffs Shale 0il Project - Occidental 0il Snale, Inc. "U.S. Department of Interior Prototype 0il Shale Leasing Program," Denver, C0, February 23, 1979.

Catnedral. Bluffs Shale 0il Venture. "Environmental Baseline Program," Denver, CO, October 1976, Final Report.

Coffin, D. L., F. A. Welder, R. K. Glanzman, and X. W. Dutton. "Geonydrologic Data from Piceance Creek Basin Between White and Colorado Rivers," U.S. Geological Survey Circ. Groundwater Series, 1968, no. 12 . 
Coffin, D. L., F. A. Welder, and R. K. Glanzman. "Geonydrology of the Piceance Creek Structural Basin Between the White and colorado Rivers, Nortnwest Colorado," U.S. Geological Survey Hydrology Investigation Atlas, 1971 , no.

Conroy, L. S. "Hydrologic and Climatologic Data, Southeast Uinta Basin, Utah and Colorado, Water Year 1978," U.S. Geolögical Survey Open File Report, 1980, no. 80-1025.

Cordiviola, S. "Hydrologic Reconnaissance of the Shale Outcrop Area in Kentucky," Proceedings of the 1982 Eastern Uil Shale Symposium, University of Kentucky, Institute for Mining and Minerals Research, Lexington, KY, 1982, 263-272.

Dale, R. H., and J. B. Weeks. "Hydrologic Analysis of the U.S. Bureau of Mines' Underground 0il-shale Research Facility Site, Piceance Creek Basin, Rio Grande County, Colorado," U.S. Geological Survey Water Resource Investigation, 1978, no. 78-28.

Everett, L. G. Groundwater Monitoring Handbook for Coal and 0il Shale Development, ETsevier: Amsterdam and New York, 1985.

Feltis, R. D. "Water from Bedrock in the Colorado Plateau of Utah," Utah State Eng. Tech. Publication, 1966, no. 15.

Ficke, J. F. "Hydrologic Data from the Piceance Creek Basin, Colorado," Colorado Water Conservation Board - Water Resource Bas. Data Release, 1974, no. 31.

Fricke1, D. G. "Hydrologic and Geomorphic Data from the Piceance Basin, Colorado," U.S. Geological Survey Open File Report, 1973, no. 78-825.

Giles, T. F., and R. E. Brogden. "Selected Hydrologic Data, Yampa River Basin and Parts of the White River Basin," U.S. Geological Survey Open File Report, 1978, no. C0-78-2.

Golder Associates, Inc. "Water Management in 0il Snale Mining," U.S. Bureau Mines Open File Report, 1978, no. 2-78.

Holines, W. F. "Results of Test Drilling for Groundwater in the Southeastern Uinta Basin, Utah and Colorado," U. S. Geological Survey Water Resources Investigation, 1980 , no. 80-951.

Hood, J. W. "Characteristics of Aquifers in the Northern Uinta Basin Area, Utah and Colorado," Utah Department of Natural Resources Technical Publication, 1976, no. 53.

Iorns, W. V., C. H. Hembres, and G. L. Oakland. "Water Resources of the Upper Colorado River Basin, Technical Report," U.S. Geological Survey Professional Paper, 1965, no. 441. 
Leonard Rice Consulting Water Engineers, Inc. "Report on Water Supply Availability for the Cathedral Bluffs Shale 0il Project," Denver, C0, September 1983.

Longenbaugh, R. A., and I. F. Wymore. "Analyses of Methods for Determination of Water Availability 'for Energy Development," Washington, DC, 1977, NTIS PB-274-080.

Mavis, J. D., Jr., and R. M. Rosain. "Water Management in the Oil Shale Industry," Chemical Engineering Progress, 1982, 78, 61-69.

McKee, J. M., and S. K. Kunchal. "Energy and Water Requirements for an Uil Shale Plant Based on Parano Process," Colorado School of Mines Quarterly, 1976, 71, 49-70.

Mehran; M., T. N. Narasimnan, and J. P. Fox. "Hydrogeologic Consequences of Modified In Situ Retorting Process, Piceance Basin, Colorado," Proceedings of the 14th 0il Shale Symposium, Colorado School of Mines, GoTden, $\mathrm{CO}$, Colorado School of Mines Quarterly, 1981, 388-400.

Miller, G. A. "Water for Western Uil Shale Development - Potential Local Supplies," U.S. Geological Survey Open File Report, 1982, no. 82-31.

Mitsch, W. J., and C. G. Lind. "Potential Impact of 0il Snale Development on Water Resources in Kentucky," Proceedings of the 1981 Eastern 0il Shale Symposium, University of Kentucky Institute of Mining and Minerals Research, Lexington, KY, 1981, $357-368$.

Patt, R. O., D. D. Adams, and D. L. Collins. "Hydrologic Data from the Naval Uil Shale Reserve No. 1, Parachute Creek Basin," U.S. Geological Survey Open File Report, 1982, no. 82-0696.

Petsch, H. E., Jr. "Streamflow Statistical Summaries for Colorado Streams Through September 30, 1975," U.S. Geological Survey Upen File Report, 1980, no. 79-1060.

Price, D., and L. L. Miller. "Hydrologic Reconnaissance of the Southern Uinta Basin, Utan and Colorado," U.S. Geological Survey Upen File Report, 1974, no. 74-352.

Probstein, R. F., and G. Harris. Water in Synthetic Fuel Production, Cambridge, MA: Massachusetts Institute of Technology Press, 1978.

Repplier, F. N., F. C. Healy, D. B. Collins, and P. A. Longmire. "Atlas of Groundwater Quality in Colorado," Colorado Geological Survey Map Series, 1981, no. 16.

Robson, S. G., and G. J. Sauliner. "Hydrogeochemistry and Simulated Solute Transport, Piceance Basin, Northwestern Colorado," U.S. Geological Survey Prof. Paper, 1981, no. 1196. 
Sauliner, G. J., Jr. "Genesis of Saline Waters of the Green River Formation, Piceance Basin, Northwest Colorado," University of Nevada, Reno, Ph.D. dissertation, 1978.

Sauliner, G. J., Jr., and K. E. Goddard. "Use of Mathematical Models to Predict Impacts of Mining Energy Minerals on the Hydrologic System in Northwestern Colorado," Mining Engineering, 1982, 34, 285-293.

Shepnerd, R. G. "Critique of Groundwater Modeling in the Piceance Basin," Proceedings of the 15th 0il Shale Symposium, Colorado School of Mines, Golden, CU, 1982, 559-572.

Taylor, 0. J. "Three Dimensional Mathematical Model for Simulating the Hydrologic System in the Piceance Basin, Colorado," U.S. Geological Survey Open File Report, 1982, no. 82-0637.

Taylor, 0. J. "Hydrologic Information Needs for 0il Shale Development, Northwest Colorado," U.S. Geological Survey Water Resources Investigation, 1982, no. $82-4076$.

Teller, R. W., and F. A. Welder. "Groundwater Potential of the Leadville Limestone on the White River Uplift in Garfield and Rio Blanco Counties, CU," U.S. Geological Survey water Resources Investigation, 1983, no. 83-4036.

Tipton and Kalmbach, Inc. "Cb-Tract Hydrology, Mine Dewatering, Water Use and Augmentation," Denver, CO, August 1977.

Van Arsdall, T. C., and C. E. Twilley. "Water Availability for an 0il Shale Industry in Kentucky," Proceedings of the 1982 Eastern Uil Shale Symposium, University of Kentucky, Institute for Mining and Minerals Research, Lexington, KY, 1983, 253-262.

Water Resources Council. "Synthetic Fuels Development for the Upper Colorado Region Water Assessment," Federal Register, July 6, $1981,46(128), 35054-70$.

Weeks, J. B. "Digital Model of Groundwater Flow in Piceance Basin, Colorado," U. S. Geological Survey Water Resources Investigation, $1978,78-46$.

Weeks, J. B., and F. A. Welder. "Hydrologic and Geophysical Data from the Piceance Basin, Colorado," Colorado Water Conservation BoardWater Resources Bas. Data Release, 1974, no. 35.

Weeks, J. B., G. H. Leaves7y, F. A. Welder, and G. J. Sauliner, Jr. "Simulated Effects of Uil Shale Development on Hydrology, Piceance Basin, Colorado," U.S. Geological Survey Professional Paper, 1974, no. 908.

Welder, F. A., and G. J. Sauliner, Jr. "Geonydrologic Data from 24 Test Holes Urilled in the Piceance Basin, colorado," U.S. Geological Survey Upen File Report, 1978, no. 78-734. 
Wright Water Engineers, Inc. "Preliminary Hydrogeologic Report, Colorado Federal Tract C-a, Piceance Creek Basin, Colorado," 1973, Denver, Co.

Wymore, I. F. "Estimated Average Annual Water Balance for Piceance and Yellow Creek Watersheds," Colorado State University Technical Report, 1974, no. 2.

Wymore, I. F. "Water Requirements for Stabilization of Spent Shale," Ph.D. dissertation, Colorado State University, Fort Collins, Co, 1974.

Wyoming State Engineer's Office. "Water and Related Land Resources of the Green River Basin, Wyoming," Wyoming Water Progress Report, 1970 , no. 3 . 


\section{Special Problems of Shale 0il}

\section{Composition}

Raw shale oil has a high pour point, is very viscous, and can form sludge when stored. It deteriorates if stored for prolonged times (BLM 1973). Raw snale ofl contains a significant amount of arsenic. When transported in pipelines and tank trucks, this arsenic can adhere to the sides of the pipe and tanks. Arsenic is not compatible with ordinary petroleum refinery processes. Raw shale oil and petroleum crude oil cannot be used in the same transportation systems. The arsenic in the raw shale oil would contaminate the petroleum crude oil (Towers 1981). Poulson et a1. (1977) reported arsenic concentrations in cores taken from the Mahogany Zone in Colorado and Utah ranging from $18 \mathrm{mg} / \mathrm{kg}$ to $86 \mathrm{mg} / \mathrm{kg}$.

The composition of raw shale oil from 25 gpd shale is $13.8 \%$ by weight organic matter. This organic matter contains $80.5 \%$ carbon, 10.3\% nydrogen, $2.4 \%$ nitrogen, $1.0 \%$ sulfur, and $5.8 \%$ oxygen (BLM 1973). The proposed 50,000 DDl/day colony 0il Snale Project, near Rifle, Colorado, would have produced $531 \mathrm{1b} /$ day of arsenic and 140 tons/day of ammonia. The properties of raw shale oil retorted by three different methods are presented in Table 6 (BLM 1973). Arsenic concentration in crude shale oil from Colorado was observed to range. from 2.2 to $53 \mathrm{mg} / \mathrm{kg}$ (Poulson et a1. 1977).

Upgraded shale oil is similar to light to very light crude oil from Libya, Nigeria or Egypt (BLM 1981). It is compatible witn existing crude oil pipelines and tank venicles. Properties of upgraded shale oil are presented in Table 7.

Table 6. Properties of Raw Shale 0ils

\begin{tabular}{lccc}
\hline Properties & Gas combustion & Union & Tosco \\
\hline Gravity, ${ }^{\circ}$ API & 19.7 & 20.7 & 28.0 \\
Sulfur, wt \% & 0.74 & 0.77 & 0.80 \\
Nitrogen, wt \% & 2.18 & 2.01 & 1.70 \\
Pour Point, ${ }^{\circ} \mathrm{F}$ & 80 & 90 & 75 \\
Viscosity, & 256 & 223 & 120 \\
SUS $100^{\circ} \mathrm{F} *$ & & & \\
\hline
\end{tabular}

*Saybolt Universal Seconds at $100^{\circ} \mathrm{F}$ 
Table 7. Properties of an Upgraded Shale 0il

\begin{tabular}{lc}
\hline Gravity, ${ }^{\circ}$ API & 46.2 \\
Sulfur, wt \% & 0.005 \\
Nitrogen, wt \% & 0.035 \\
Pour Point, ${ }^{\circ} \mathrm{F}$ & $<50$ \\
Viscosity, & \\
SUS $0100^{\circ} \mathrm{F} \star$ & 40 \\
\hline
\end{tabular}

*Saybolt University Seconds at $100^{\circ} \mathrm{F}$

Pipeline vs. Tank Car

A $50,000 \mathrm{bbl} /$ day oil snale project would require 210 tank cars of 10,000 gallon capacity each day. This would be about 2 unit trains of 100 tank cars each. Most rail systems would be able to handle this traffic with no strain on the system. The cost of moving raw shale oil by unit train compared to pipeline is very nigh. Pipelines are cheaper by several times than any other means of transportation (BLM 1979).

\section{WESTFRM NII. SHALE AREAS}

The western oil snale areas are divided among three states: Colorado, Utah, dind Wyoming. They share common traits of rugged rellef and 1solation.

\section{Piceance Basin of Western Colorado}

\section{Topography}

This area covers about 1600 square miles hounded by the White River, the Grand Hogback, the Roan Plateau, and Cathedral Bluffs. It has the relief of a large shallow bowl, cut by drainages. The southern edge has stark 'rellef and few, though very steep, drainages. Piceance and Yellow Creeks drain the majority of the area, with gently sloping radial drainages. Uther streams drain from sharply defined, deep canyons. All drainages ultimately empty into the Colorado system. This is an area of prominent cliffs, rolling mountains, and steep ridges (BLM 1973).

\section{Transportation}

Roads that service the Piceance Basin include Colorado 13/789, Colorado 64, and Rio Blanco County Road. 5. In addition, Interstate 70 passes to the south of the area. All of these roads are presently handling traffic less than their maximum capacity. There are over a 
thousand miles of secondary roads in the area; most are unimproved, dirt access roads. If oil shale development occurs, most of these roads would require upgrading, especially those that would carry heavy trucks. Rail service to the area is provided by the Denver and Rio Grande RR, with tracks to south of Craig, and tnrough Rifle. Spurs to oil shale plant sites would be required. Because of the rugged terrain, railroad construction would be very expensive (BLM 1984).

\section{Rights-of-Way}

There are five oil-and-gas pipelines of 8- to 14-inch size in the area. A $345 \mathrm{kV}$ powerline runs from Craig to Rifle. There are numerous otner smaller pipelines and electric transmission lines which service oil and gas production, ranches, and small communities. All these would provide corridors for additional rignts-of-way to handle oil shale products. Upgrading or designation of new rights-of-way would require additional environmental compliance and land-use plan amendments (BLM 1984).

\section{Book Cliffs Area of East-Central Utah}

\section{Topography}

This area is a broad basin bounded by Douglas Creek, the Uinta Mountains, the Wasatch Mountains, and the Roan Cliffs. It has rough, mountain terrain with flat valleys and is sharply cut by deep gulleys and well-defined ridges. 0il shale outcrops in cliffs and ledges on the east and south sides of the area. Elevation ranges from 4600 to over $8000 \mathrm{ft}$. This area drains into the White and Green River systems, eventually reaching the Colorado River (BLM 1973).

\section{Transportation}

There are four major roads that carry most of the traffic in this area: U.S. 40, Utan 88, Utah 45, and County Road. 262. Numerous unimproved dirt roads provide access to most of the area from these major roads. If oil shale development occurs, some upgrading of the road system will be necessary. U.S. 40 segments would be most affected (BLM 1984). There are no railroads in the immediate vicinity; however, two major lines of the Denver and Rio Grande RR pass to the south and east of the area. Rail service would be necessary to facilitate construction and supply of the plant sites, requiring a significant capital investment. Transportation of the upgraded shale oil to markets would be by pipeline.

\section{Rights-of-Way}

There are several hundred miles of right-of-way in the Book Cliffs area. These include $0 i l$ and gas pipelines, roads, and power communication lines. Major ROW corridors include Seep Ridge Road, MAPCO Pipeline, Vernal-Bonanza Road, and U.S. 40. The average width of the corridor is 0.6 mile. 0il shale development would require designating new corridors and widening some existing ones by modifying existing land-use plans, probably requiring additional environmental documentation (BLM 1984). 
Ereen River and Hashakie Basins of Southwestern Wyoming

\section{Topography}

This is an area of low mountains and semiarid basins surrounded by mountain ranges. The Green River Basin is a high desert plateau with $6300 \mathrm{ft}$. average elevation. Many intermittent drainages cut the slopes with gullies. The Washakie Basin is an area of wild terrain, with many steeply sided gullies that wind through the shales and sandstone. Both of these areas have badlands, playas, sand dunes, and steep ridges. Many parts have received very little use because of isolation and rugged terrain. The Green River is the major drainage in the area.

\section{iransporiation}

Roads that service the area inciude IH 80 , US 191, US 189, Wyoming 430, and Wyoming 28. In addition, there are many graded dirt county roads, service roads, and access trails. Most of the area is accessible by a road of some kind that would require upgrading if oil shale development occurred. Rail service is provided by the Union Pacific RR, which runs east-west through southern Wyoming. This rail system is one of the largest in the country. It is double-tracked through Wyoming, with many spurs to serve industry (BLM 1983).

\section{EASTERH OIL SHALE AREAS}

The eastern oil shale areas are concentrated in Indiana, Unio, Kentucky, and Tennessee, torming a v-shaped pattern. This contiguous area straddles two geographic regions: the central lowlands and the Appalachian Plateaus.

\section{Topography}

In contrast to the West, this area has a varied and complex terrain, the result of a complicated geologic history. Long periods of erosion, advance and retreat of glaciers, and a humid climate have resulted in a gentle, rounded topography. There are areas of giacial till and moraines in Indiana and Ohio. Karst areas (limestone plains with sinkholes and caverns) are common in parts of Kentucky and Tennessee. Ridges and eroded remnants are the main characteristics of the rest of the oil shale area. There are many large rivers that meander in deeply dissected valleys. Elevations are lower than in the west, varying from 500 to $2000 \mathrm{ft}$. (Hunt 1973).

\section{Transportation}

Transportation is not as much of a problem in this area due to its longer history of energy, mineral, and agricultural production. Also, it is an area of commerce, industry, and nigh population density. There is an extensive system of railroads that serves mining 
and manufacturing facilities. Due to a decline in industry in this region, an oil shale industry would be able to use the present transportation infrastructure (USGS 1970).

A major concern in transportation is distance. In the east, distances between probable oil shale sites and rail service, pipelines and refineries, and energy sources (especially electricity) are relatively short. One measure of distance is the ton mile, which is the distance-mass factor for moving one ton of material one mile. Ton miles for shale oil would be considerably lower in the eastern states than in the west (DOT 1982). 


\section{BIBLIOGRAPHY FOR TYPOGRAPHY AND TRANSPORTATION}

Bureau of Land Management (BLM). Draft EIS, La Sal Pipeline Company, Snale 0il Pipeline, Colorado State Office, Denver, 1981.

BLM. Draft Environmental Statement, $\mathrm{CO}_{2}$ Project, Wassen Field/Denver Unit, New Mexico State Office, Santa Fe, 1979.

BLM. Prototype 0il Snale Leasing Program EIS, Wasnington, DC, 1973.

BLM. Piceance Basin Resource Management PIan and EIS, White River Resource Area, Craig, C0, District, 1984.

BLM. Green River-Hams Fork Region Coal EIS, Round Two, Colorado State office, Denver, 1983.

BLM. Green River-Hams Fork Region Coal EIS, Colorado State Uffice, Denver, 1980.

BLM. Book Cliffs Resource Management Plan and EIS, Vernal, IIT, District, 1984.

Department of Transportation. Draft EIS - EX Part 50 Regulations, Washington, OC, 1983.

Geological Survey. National Atlas of the United States of Anerica, U.S. Department of the Interiur, Washingluin, $D C, 1970$.

Poulson, R. E., J. W. Smith, N. B. Young, W. A. Robd, and J. T. Spedding. "Minor Elements in Uil Shale Products," Laramie, Energy Research Center Report, LERC RI-71/1, 1971.

Towers, James, Senior Staff Engineer. Exxon Pipeline Company, Houston, Texas, Personal Communication, 1981. 


\section{HUMAN RESOURCES \\ by Audie Blevins}

For this plan, human resources refer to the labor force needed for the construction and operation of oil shale mining and processing plants or similar large scale energy development. Discussion focuses primarily on direct labor needs. Indirect labor requirements (construction and maintenance of ancillary support structures such as new schools, government offices, and wholesale/retail enterprises) will not be discussed in detail.

\section{Direct Employment Needs}

The literature, though extensive, does not provide consistently detailed estimates of labor force requirements for the construction of oil shale plants (or other large energy developments) or for the mining and processing of oil shale (or other natural resources). The location of the oil shale and the technology (open pit, underground mining, or in-situ processing) used to process it affect labor force requirements. Consequently, the labor force estimates in this plan are adjusted for the location of the resource development (Kentucky, with a relatively nigh population density, or Colorado, Utan, and Wyoming, with low population densities), the technology used, and the volume of production.

LeBus (1984) notes that peak construction requirenents for Union 0il in Colorado and Soutnern Pacific Petroleum Means project in Kentucky are within the range of 2400 and 2600 workers for 10,000 bbl/day facilities. Similarly, Miller (1981) reports a peak construction labor force of 2627 and an operating work force of 900 for possible shale developments of 30,000 blol/day capacity in Fleming County, Kentucky (Table 2). Another estimate is that a surface retorting/processing plant producing 50,000 bbl/day of shale oil products would have a peak construction labor force of 3300 and an operating labor force of 429. Apparently, there are some economies of scale in using a large facility; however, the increased size of the peak construction labor force is not proportionate to increased production. Additional modifications in labor force predictions are made when plans call for stacking 10,000 bbl/day modules. Stacking involves beginning construction of a second 10,000 bbl/day module after completing the first 10,000 bbl/day module. This approach lengthens the construction period, minimizes peak construction labor force demand, and overlaps the construction labor force for module 2 with the operating labor force of module 1. Each of these scenarios involves different labor force assumptions, different impacts on the local communities, and the ability of companies to compete for labor.

Table 8 documents the tremendous diversity of labor force estimates for different energy resource development and processing technologies in the West. Included in the estimate are the size of operation, type of technology, and type of resource. Estimates were derived only for the West and are based on work by Carasso (1975) of the Bechtel corporation. The uncertainty margins (confidence limits 
Table 8. Manpower Requirements for Energy Facilities

\begin{tabular}{|c|c|c|c|c|}
\hline \multirow[t]{2}{*}{ Facility } & \multirow[t]{2}{*}{ Facility Size } & \multicolumn{2}{|c|}{ Construction } & \multirow{2}{*}{ Operation } \\
\hline & & $\begin{array}{l}\text { Duration } \\
\text { (Years) }\end{array}$ & $\begin{array}{c}\text { Peak } \\
\text { Employment }\end{array}$ & \\
\hline \multicolumn{5}{|l|}{ Coal } \\
\hline $\begin{array}{l}\text { Surface mine } \\
\text { Underground mine } \\
\text { Gasification } \\
\text { Liquefaction } \\
\text { Power plant }\end{array}$ & $\begin{array}{c}12.7 \mathrm{MMtpy} \\
12.7 \mathrm{MMtpy} \\
250 \mathrm{MMcfd} \\
100,000 \mathrm{bDI} / \mathrm{day} \\
3000 \mathrm{MWl} \text {. }\end{array}$ & $\begin{array}{l}5 \\
6 \\
5 \\
7 \\
8\end{array}$ & $\begin{array}{r}210 \\
820 \\
4680 \\
5220 \\
2540\end{array}$ & $\begin{array}{r}550 \\
2530 \\
590 \\
3060 \\
440\end{array}$ \\
\hline \multicolumn{5}{|l|}{ ofl Snale. } \\
\hline $\begin{array}{l}\text { Surface mine } \\
\text { Underground mine } \\
\text { Retort/Processing }\end{array}$ & $\begin{array}{c}140,000 \mathrm{tpd} \\
140,000 \mathrm{tpd} \\
100,000 \mathrm{bD} / / \mathrm{day}\end{array}$ & $\begin{array}{l}4 \\
4 \\
6\end{array}$ & $\begin{array}{r}710 \\
710 \\
2680\end{array}$ & $\begin{array}{r}660 \\
1180 \\
650\end{array}$ \\
\hline Crude oil production & $100,000 \mathrm{bb} 1 / \mathrm{day}$ & 7 & 3920 & 2050 \\
\hline $\begin{array}{l}\text { Natural gas } \\
\text { production }\end{array}$ & $250 \mathrm{MMc} f d$ & 5 & 1700 & 790 \\
\hline $\begin{array}{l}\text { Uranium } \\
\text { Upen pit mine } \\
\text { Underground mine } \\
\text { Milling }\end{array}$ & $\begin{array}{l}12 \mathrm{nn} \text { t.pd } \\
1200 \mathrm{tpd} \\
1200 \mathrm{tpd}\end{array}$ & $\begin{array}{l}5 \\
5 \\
3\end{array}$ & $\begin{array}{r}80 \\
440 \\
90\end{array}$ & $\begin{array}{l}180 \\
840 \\
110\end{array}$ \\
\hline
\end{tabular}

Source: Energy from the West, Volume I, Summary Report prepared by Science and Public Program of the University of Oklahoma for the Office of Research and Development, U.S. Environmental Protection Agency, Washington, DC, Tajoles 3-17 and 3-18, 1981.

Note: Coal liquefaction, gasification, and oil shale processing involve manpower uncertainties of $-30 \%$ to $+75 \%$ while other established technologies involve uncertainties of $-10 \%$ to $+20 \%$. 
Table 9. Labor Force Estimates for oil Shale Commercialization in Fleming County, Kentucky (30,000 bb1/day Plant)

\begin{tabular}{lcc}
\hline Employment & Total Impact & Fleming County Impact \\
\hline & & \\
Permanent employment & 2627 & 499 \\
Peak construction & 900 & 171 \\
Operating phase & & \\
& & \\
Local secondary employment & 1655 & 314 \\
Peak construction & 1278 & 243 \\
Operating phase & & \\
& & \\
Local secondary employment--by & industrial. category \\
(70\% capture rate) & & 28 \\
Operating phase & 146 & 39 \\
Construction & 207 & 14 \\
Transportation & 75 & 11 \\
Commercial \& public utilities & 56 & 14 \\
Wholesale trade & 74 & 9 \\
F.I.R.E. & 49 & 33 \\
Personal business & 174 & 27 \\
Professional services & 142 & \\
Government & & \\
\hline
\end{tabular}

*F.I.R.E. - Finance, insurance, and real estate employment.

Source: Miller, Stephen H., "Potential Economic Impact of Uil Shale Commercialization in Fleming County, Kentucky," 1981 Eastern 0il Shale Symposium Proceedings, Lexington, KY, IMMR 82/066: 295.

Note: Counties included in impact area are Bath, Carter, Fleming Lewis, Mason, Nicholas, Robertson, and Rowan.

Table 10. Estimated Demand/Supply For Selected Crafts At 2600 Workers Peak Demand (10,000 DDl/day Plant)

\begin{tabular}{lccc}
\hline Craft & Peak Demand & Supply & $\begin{array}{c}\text { Assumed 25\% } \\
\text { Capture Rate }\end{array}$ \\
\hline Boflermakers & 182 & 923 & 231 \\
Electricians & 260 & 2880 & 720 \\
Ironworkers & 234 & 1892 & 473 \\
Pipe fitters & 936 & 2900 & 725 \\
\hline
\end{tabular}


Source: LeBus, Margaret M. "A Preliminary Assessment of the Potential for Adverse Social and Economic Impact from Shale Development in Kentucky Knobs Counties," 1983 Eastern 0il Shale Symposi um, IMMR83/089.

Note: Labor supply comes from four metropolitan areas: Lexington, Ashland/Huntington, Louisville, and Cincinnati.

Table 11. Major Skill Requirements, Ful1-Size Module Construction

$\begin{array}{lcc}\text { Skilled } & \text { Average } & \text { Peak } \\ \text { Personnel } & \text { Employment } & \text { Employment }\end{array}$

Boilermakers

Ironworkers

Millwrights

Operators

Pipe fitters

Carpenters

Cement finishers

Laborers

Brick layers

Teamsters

Electricians

Insulators

Painters

Sneet metal workers

Total

Source: U.S. Department of Energy, Draft Environmental Impact Statement, Mining, Construction and Operation for a Full Size Module at the Anvil Points 0il Snale Facility, Rifle, Garfield County, Colorado, August 1980, TavTe 5-13. 
for estimators) for the estimates are $-30 \%$ to $+75 \%$ for developing technologies such as coal liquefaction, gasification, and oil shale processing, and $-10 \%$ to $+20 \%$ for developed technologies such as surface mining, underground mining, crude oil production, and power plant construction. Uncertainty margins increase far greater with multiple rather than single projects. For multiple projects the number of laborers increase, but not proportionately, to the sum of the size of the respective projects because of the possibility of sharing laborers when different peak construction periods do not overlap.

LeBus (1984) suggests that craft labor requirements for shale development are similar to those of power plants and coal conversion plants. Labor forces are estimated by skill level for different projects in Tables 9, 10, and 11. Table 9 lists skills needed for operating a 30,000 bbl/day oil shale plant, and Tables 10 and 11 ist major skills needed for the construction of an $0 i 1$ shale processing plant. The estimates for a peak demand are 182 Doilermakers, 260 electricians, 234 ironworkers, and 936 pipe fitters (Table 10) These occupations account for 1612 of the 2600 workers at peak demand. The peak and operating skills needed for a smaller test module at Anvil Points 0il Shale Facility, Rifle, Colorado are in Table 11.

Interestingly, LeBus (1984) suggests that in the Knobs Counties, Kentucky, assuming a $25 \%$ capture rate (percent of available local laborers with needed skills hired for the project), the supply of local laborers is sufficient in the skill categories of boilermakers, electricians, and ironworkers, but insufficient for pipe fitters to meet project deinand for the peak employment period. This estimate includes capturing labor from existing industries and perhaps creating competition for skilled laborers by pushing up wages. LeBus suggests that in relatively high population density areas, labor availability is not a major issue and that similar conditions probably exist in the other eastern oil shale states.

\section{Indirect Employment Needs}

Indirect employment covers the additional jobs for construction workers and operating personne1. Estimations for these employees vary from project to project, depending on density of population and proximity to cities. For simplicity, only one set of multipliers, the ratio of nonbasic to basic jobs, are included. Miller (1981) estimates that for a peak construction force of 2627 there would be 1655 indirect jobs created in Fleming County, Kentucky, and the surrounding seven counties, or a ratio of .63 . The ratio changes to 1.42 for an operating labor force $(900$ operating jobs create 1278 indirect jobs). Employers for these new indirect jobs would compete for labor with oil snale development jobs and with existing employers in the eight-county region. This would probably force wages up in the support industries and attract new workers into the area. 
Estimates of labor force composition are provided annually by the Bureau of Economic Analysis (Department of Labor), but there is generally a year's lag time on the data. Consequently, labor force data published in 1986 refers to 1984. Information is available on national, regional, state, and county bases. Data are provided for metropolitan and nonmetropolitan areas. Records are available beginning in 1973 and up until 1986 (with the two-year 1ag). Employment data are divided into broad categories: total employment; employment by wage and salary; proprietors; farm and nonfarm; industry, including farming, agricultural services, fishing, mining, construction, and manufacturing; transportation/public utilities; wholesale trade; retail trade; finance, insurance, and real estate; services; and government.

Labor availability by skill level is recorded at the state level and in some cases at the county level by labor union locals and state union offices (e.g., 1983 Directory of Labor Organizations, Kentucky Department of Labor).

\section{Availability of Support Services}

In addition to demands for labor, shale development will make demands on existing community services. In some cases, the construction of additional community services will be required. This analysis is limited to a general discussion of the types of services available in most communities and to the government, state, and local publication sources that provide information at the local level. Some states maintain extensive data banks that are periodically updated and provide information on most if not all the services discussed below. The Colorado Resource Information System (CRIS) (Hecox 1983-84) stores data on all courlties in colorado and can be readily accessed through Colorado State University (similar data for Montana is available at Montana State University).

The discussion of local services describes the types of services needed to support a large influx of workers and their families. The reader is also referred to ililler (1982), Energy from the West (1977), Department of Interior (1983), and U.S. Department of Energy (1980) for examples of the types of human services needed to support shale development requiring about 2600 construction workers and 500 or inore permanent operators. These numan services include health, education, housing, retail sales, service, commercial, clerical, manufacturing, recreation, and government (city/county, law enforcement, fire protection, water, sewage, landfill, and streets and oridges). Branch et al. (1984) discuss typical national standards for the ratio of respective personnel, size of service facility, and cost of services per 1000 population.

Government Services. Water, sewage treatment, garbage collection (including sanitary landfill), police protection, fire protection, streets and bridges, and community goverment are common services provided by communities. Some communities also provide libraries, 
parks and recreation, and weed and pest control. Services available, current service capacity, and surplus capacity, as well as current costs, are published annually by most governments and are located in county/municipal budgets. Similar information is available for each service le.g., information on law enforcement services for all counties is in the Uniform Crime Reports compiled annually by the Federal Bureau of Investigation).

Medical Facilities. Hospital facilities and the number and type of physicians available are published by the county/community. Information is provided on public/private provision of service, existing capacity, surplus capacity, and cost of service (County and City Data Book 1983).

Housing. A survey of housing stock is provided by the Decennial Census of the United States $(1980$ is the most current census data available). Census of Housing provides comparable data for all counties in the U.S. Several states provide more recent estimates of housing stock by county. At the local level, county tax assessor offices provide detailed information regarding housing stock. Consequently, once the site of shale development is determined, detailed information on current housing stock can be readily obtained, including the number of units, units occupied, surplus capacity (vacancy rate), and the current cost of both owner-occupied and rental units. Refer to Bureau of the Census, Current Population Reports and the County and City Data Book, 1983 for recent information regarding housing stock at city, county, state, regional, and national levels.

Schools. Annual information on the number of elementary and secondary schools and their enrollments is available, including the number of classrooms, teacher-student ratio, number of students, and cost per student. Surplus capacity and ability to absorb additional students can be estimated. See U. S. Bureau of the Census, Finances of Public School Systems in 1984-1985, series 85, no. 10 for county, state, and national data.

Retail and Wholesale Business. Survey of Current Business Patterns provides data for the U.S., individual states, and counties on the number of retail and wholesale businesses and the volume of sales. See U.S. Bureau of the Census, County Business Patterns, 1985 and the County and City Data Book, 1983.

\section{Data Gaps}

Temporary/Permanent Labor Force

It appears that the impact of permanent workers on a local area is quite different than the impact of temporary workers. Additional work needs to be undertaken to address such issues as worker cominitiment to the local community, the role of newcomers and oldtimers in maintaining a sense of community, and the question of whether a sense of community is related to worker turnover. If differences exist, then it needs to be determined if the differences are related to temporary or permanent employees. 


\section{Single/Multiple Project Effects}

Generally, labor force projections are based on a single project. Yet, the reality of industrial development dictates that the possibility of several large scale projects being undertaken at one time (Garfield, Colorado; Rock Springs, and Gillette, Wyoming) be considered. Questions remain as to whether economies of scale exist by having multiple projects or whether multiple projects compound recruitment of employees and problems in providing human services at the community/county leve1. For example, a single project might absorb labor from surrounding communities (50 or 75 miles radius), thereby avoiding an influx of large numbers of newcomers into the community and avoiding additional demands on local services. However, multiple projects create competition for $10 \mathrm{cal}$ labor as well as the necessity to recruit outside labor, which will result in demands on existing services and cause assimilation problems for newcomers.

\section{Indirect Employment}

There is no exact method for estimating total population increase for any given project. The number of new service jobs, the number and types of new businesses, and the number of new students resulting from new basic (direct) and induced employment are important but unanswered questions. The context of development (nigh density versus low density population areas) seems to be important but the relationship is not exact. One research task would be to compare multipliers--the ratio of direct and induced labor for comparable projects (type and size) in two different localities that varied in population density.

\section{Human Resources}

The literature is vague regarding the appropriate unit of analysis for evaluating project impacts. Does one look only at the nearest community, the county in which development occurs, or does one examine surrounding communities and counties? What are the spillover effects of development? Several researchers suggest regional approaches while others establish defined limits of 50 or 100 miles. other approaches examine the ease of commuting and strength of attraction of the development through the use of gravity models of human migration. Research needs to be conducted to test the various approaches to defining impacts and to quantify the relationship between context of development and type/size of industrial development.

\section{Infrastructure Availability and Possible Expansion}

The question, "What are the appropriate service standards for low density and nigh densily dreds?" needs to be addrcssed. What are the tine frames for constructing new facilities, reasonable costs, and problems in recruiting trained personnel? Do these factors vary across regions? 
An important but neglected area is the nistory of a community located near a proposed development site. Does experience with rapid changes in employment/population enhance a community/county's ability to provide needed human services? Some of the literature suggests that community nistory is important to maintaining old services and providing new human services when growth occurs. Detailed nistories of communities that have experienced cycles of growth and decline (boom/bust) such as Gillette, Wyoming, need to be compiled to determine whether experience aids in adjusting to the human needs created by rapid population growth. 


\section{BIBLIUGRAPHY FOR HUMAN RESOURCES}

Albrecht, Don E., Steve H. Murdock, R. Larry Leistritiz, and John M. Halstead. "The Impacts of Energy-Resource Projects on Rural Communities in the Western United States," in Research In Rural Sociology and Development; Fear, Frank A., and Harry K. Schwarzweller, eds.; 109-123.

Albrecht, S. L. "Commentary," Pacific Sociological Review, 25 1982, 297-306.

Albrecnt, S. L. "Socio-Cultural Factors and Energy Resource Development in Rural Areas in the West," Journal of Environmental Management, $7(\mathrm{Ju} 1 \mathrm{y}), 1978,73-90$.

Allen, E. H., and L. Hansen. Financing Infrastructure in Energy Production Areas. Logan, UT: Rocky Mountain Institute for Policy Research, 1975.

Andrews, Donald R., Steve H. Murdock, and Lonnie L. Jones. "Private and Public Sector Economics of Lignile-Erieriyy Resource Development in Rural Central Texas," Southern Journal of Agricultural Economics, 15(2), 1983, 55-63.

Argonne National Laboratory. A Framework for Projecting Employment and Population Changes Accompanying Energy Development, Argonne, IL: Argonne National Libraries, 1976.

Ascher, W. Forecasting: An Appraisal for Policy Makers and Planners, Baltimore, MD: Johns Hopkins University Press, 1978.

Atherton, Carol Coop. "Legal Requirernents for Environmental Impact Reporting," in Handbook for Environinental Change, McEvoy, James, III, and Thomas Dietz, eds.; New York: Wiley, 1977.

Bacigalupi, Linda, and William R. Freudenherg, "Increased Mental Health Caseloads in an Energy Boomtown," Administration in Mental Health, 10(4), 1983, 306-322.

Baldwin, Thomas E., Diana Dixon Davis, Erik J. Stenenjem, and Thomas D. Wolsko. A Socioeconomic Assessment of Energy Developinent in a Small Rural County, Argonne, IL: Argonne National Laboratory, 1976.

Ballard, Chester, and James Copp. "Social Change in an Uil-Boom Community," presented at the Annual Meeting of the Southwestern Sociological Association, Dallas, TX, 1981.

Barrows, Richard, and Marg Charlier. "Local Government Uptions for Managing Rapid Growth," in Coping with Rapid Growth in Rural Communities, Weber, Bruce, and Robert Howell, eds.; Boulder, CO: Westview Press, 1982. 
Barry, Hamlet J. "A Review of the State Policies and Concerns about Rapid, Federally Assisted 0il Shale Industrialization," presented at 14th 0il Shale Symposium Proceedings, Colorado school of Mines, Golden, C0, 1981.

Bates, V. E. "The Impact of Energy Boom-town Growth on Rural Areas," Social Casework, 59, 1978, 73-82.

Beck, E. M., Enuis Dotson, and Gene F. Summers. "Effects of Industrial Developments on Heads of Households," Growth and Change, 14(Ju1y), 1973, 16-19.

Behen, R. W. "Natural Resources, People, and the Quality of Life," in Population, Resources, and the Future: Non-Malthusian Perspectives, Bahr, H. M., B. A. Chadwick, and D. L. Thomas, eds.; Provo, UT: Brigham Young University Press, 1972.

Bender, Lloyd A., and Thomas L. Stinson. "iMitigating Impacts of Rapid Growth on Local Government," Journal of the Community Development Society, 15(1), 1984, 59-73.

Bender, L. D., and T. F. Stinson. "Typologies of Local Natural: Resource Development Problems in the West and Their Mitigation. Strategies," submitted by the Economic Research Service, U.S.D.A., to the Office of Research and Development, Office of Environmental and Engineering Technology under contract EPA IAG 79-D-X-0519, 1981.

Bertrand, Alvin L. "Rural Social Organizational Implications of Technology and Industry," in Rural U.S.A., Ford, Thomas R., ed.; Ames, IA: Iowa State University Press, 1978.

Bogue, Donald. Techniques for Making Functional Population Projections, Chicago: Community and Family Study Center, 1974.

Bowles, Roy T. Social Impact Assessment in Small Cornmunities: An Integrative Review of Selected Literature, Toronto, Canada: Butterworth \& Company, 1981.

Branch, Kristi M., Douglas A. Hooper, and Stan L. AlDrecht. "The Process of Change in the Social Organization of Communities: Energy Development in Rural Areas," Rural Sociology and Development, 2, 1985, 91-107.

Branch, K., D. A. Hooper, J. Thompson, and J. Creighton. Guide to Social Assessment: A Framework for Assessing Social Change, BouTder, CO: Westview Press, 1984.

Branch, Kristi, James Thompson, James Creighton, and Douglas Hooper. "Guide to Social Assessment," prepared for the Bureau of Land Management Social Effects Project by Mountain West Research, Inc.., Billings. MT, 1985. 
Branscome, James. "Stripping For Pleasure and Profit," Commonwealth, 95(December 3), 229-231.

Breyer, Stephen, Paul Cnernoff, and Oram W. Ketcham. "Wnat Researchers Need to know about the Law and the Courts," in The Use/Nonuse/Misuse of Applied Social Research in the Courts, So $\overline{k s,}$ Michael J., and Charles H. Baron, eds.; Cambridge, MA: ABT, 1980.

Brookshire, D. S., and Ralph C. D'agre. "Adjustment Issues of Impacted Communities, or are Boomtowns Bad?", Natural Resources Journal, 20(July), 1980, 523-546.

Bultena, Gordon L. "Energy Goals Assessment: Implications of Methodological Procedures for Goal Determination," Midwest Soctological Society, St. Louis, M0, 1976.

Burdge, Rabel, and Sue Jonnson. "The Sociocultural Aspects of the Effects of Resource Development," in Handbook for Environmental Planning: The Social Consequences of Environmental Change, McEvoy, James, III, and Thomas Dietz, eds.; New York: John Wiley, 1977.

Burdge, R. J. "Some Potential Problems in Doing Social Impact Assessment Research," presented at the Annual Meeting of the Rural Sociological Society, Madison, WI, 1977.

Burdge, Rabel B., and Paul Opryszek. "Un Mixing Apples and Uranges: The Sociologist Does Impact Assessment with Biologists and Economists," in Integrated Impact Assessment, Rossini, Frederick A., and Alan L. Porter, eds.; BouTder, CO: Westview Press, 1983.

Bureau of Land Management. "Draft Environmental Impact Statement on the Federal 0il Snale Management Program," Department of the Interior, Wasnington, UC, 1983.

Caplan, Nathan. "A Minimal Set of Conditions Necessary for the Utilization of Soclal Sclence Knowledge in Policy Formation at the National Level," in Using Social Research in Public Policy Making, Weiss, Carol H., ed.; Lexington, MA: Lexington, 1977.

Carley, Michael J., and Edwardo S. Bustelo. Social Impact Assessment and Monitoring: A Guide to the Literature, Boulder, Co: Westview Press, 1984.

Carley, Micnael J., and Ellan 0. Derow. Social Impact Assessment: A Cross-Disciplinary Guide to the Literature, London: Policy Studies Institute, 1980.

Carter, Mickale. "The Montana Major Facility Siting Act," Montana Law Review, 45, 1984, 113-132. 
Christiansen, B., and T. H. Clack, Jr. "A Western Perspective on Energy: A Plea for Rational Energy Planning," Science, 194(November), 1976, 578-584.

Clemente, Frank, and Gene F. Summers. "The Journey to Work of Dural Industrial Employees," Social Forces, 54(2), 1975, 212-218.

Colorado Department of Health. Assessment of the Cumulative Environmental Impacts of Energy Development in Northwestern Colorado, with the U.S. EPA, Region VIII Uffice, Dept. of Health, Denver, CO, 1980.

Colorado Department of Natural Resources. Active/Proposed Energy Sites in Northwest Colorado: 1981, Production, Employment, and Location Information, Executive Director's uffice, Colorado Department of Natural Resources: Denver, CO, 1981.

Colorado Department of Natural Resources. Colorado 0il Shale: The Current Status, Department of Natural Resources: Denver, CO, 1979.

Colorado Department of Natural Resources. Energy and Resource Management Techniques for Northwest Colorado: An Introduction to the Colorado Resource Information System, Executive Director's Office, Colorado Department of Natural Resources: Denver, CO, 1981.

Colorado Department of Natural Resources. Projections of Northwest Colorado Energy Development and Associated Impacts Through the Mid 1990's: A Preliminary Regional Perspective, Executive Director's Office, Colorado Department of Natural Resources: Denver, CO, 1980.

Colorado Energy Research Institute. Energy Issues in Colorado's Future, Golden, C0, Colorado Energy Research Institute, 1980.

Colorado Energy Research Institute. Colorado 0il Snale Development Scenarios, 1981-2000, Golden, Co: Colorado Energy Research Institute, 1981.

Colorado Energy Research Institute. Colorado 0il Snale Development Scenarios, 1985-2000. Golden, CO: Colorado Energy Research Institute, 1980.

Colorado School of Mines and Colorado Energy Research Institute. 0il Snale 1982: A Teclinulugy and Policy Primer, Colorado Energy Research Institute: Golden, CO, 1981.

Congressional Quarterly. Energy Policy, Second Edition. Wasnington, DC: Congressional Quarterly, 1981, U.S. Government Printing Uffice.

Conti, E. A. "The Cultural Role of Local Elites in the Kentucky Mountains: A Retrospective Analysis," Appalachian Journal, 7. $1979-1980,51-69$. 
Cortese, C. F., and B. Jones. "The Sociological Analysis of Boomtowns," Western Sociological Review, 8(1), 1977, 76-90.

Costain, W. Douglas. "Energy Policy and Boom/Bust Cycles: Government Action and Instability in the Development of 0il Shale," Policy Studies Journal, 13(2), 1984, 401-411.

The Council of State Governments. 1973 Suggested State Legislation, Vol ume XXXII, 1973.

The Council of State Governments. Suggested State Legislation, Volume $X X X V, 1976$.

Cumulative Impacts Task Force, Inc. "Articles of Incorporation," Executive Director's Office, Colorado Department of National Resources, Denver, CO, 1982.

Cuttunay, R. W. "A Bust of Expectations," The Mines Magazine, Colorado School of Mines, Golden, C0, 1982.

Dalstead, Norman L., Larry F. Leistritiz, and Thor Hertsgaard. "Assessment of Economic Impacts Associated with a coal Gasification Plant Located in Dunn County, North Dakota," Department of Agricultural Economics, Fargo: North Dakota State University, 1976.

Davis, David H. Energy Politics, 3rd Ed., New York: St. Martin's Press. 1982.

Davis, John. "Western Boom Town Financing Proilems: Selected State Legislative Responses," Journal of Contemporary Law, 5, 1979, 319-337.

De'Ath, colin. "Social Impact Assessment: A Critical Tool in Land-Development Planning," International Social Science Journal, 34(93), 1982, 441-450.

DeLeon, $P$. "Scenario Designs: An Uverview," Simulations and Games, $\underline{6}(1), 1975,39-60$.

DeSouze, Glenn R. System Methods for Socioeconomic and Environmental Impact Analysis, Lexington, KY: D.C. Heath and Company, 1979.

DeYoung, Alan J. "Econornic Development and Educational Status in Appalacnian Kentucky," Comparative Education Review, 29(1), $1985,47-67$.

Delvecq, A. L., A. H. Van de Ven, and D. H. Gustafson. Group Techniques for Program Planning: A Guide to Nominal Group and Delphi Processes, Glenview, IL: Scott Foresman.

Denver Research Institute. Socioeconomic Impact of Western Energy Kesource Development, Washington, DC: Council on Environmental Quality, 1979. 
Department of Natural Resources and Environmental Protection. Draft of 0il Shale Regulations, Lexington, KY, 1983.

Detomasi, D. D., and J. W. Gartell, eds. Resource Communities: A Decade of Disruption, Boulder, CO: Westview Press, 1984.

DiNitto, Diana M., Reuben R. McDaniel, Jr., Timothy W. Ruefli, and James B. Thomas. "Methodological ubservations on Applied Benavioral Science," The Journal of Applied Behavioral Science, 22(1), 1966, 77-93.

Dials, G., and E. C. Moore. "The Cost of Coal," in Appalachia: Social Context Past and Present, Ergood B., and B. E. Kuhre, eds.; Dubuque, IA: Kenda11/Hunt Pub 1. Co., 1978.

DoDbs, T. L., and P. E. Kiner. "Two Manpower Location Aspects of Energy Resource Development: Case of the Wyoming Industry," Annals of Regional Science, $8(2), 1974,118-130$.

Drabenstott, Mark, Marvin Duncan, and Maria Borowski. "0il Shale in the United States: Prospects for Development," Federal Reserve Bank of Kansas City, 69, 1984, 31-48.

Duerken, Christopher J. Environmental Regulation of Industrial Plant Siting: How to Make it Work Better, The Conservation Foundation: Washington, JC, 1983.

Eastman, C., D. Hoffer, and A. Randall. Socioeconomic Characteristics and Environmental Concern: The Case of the Four Corners Electric Power Complex, Las Cruces, NM: Agricultural Experiment Station, New Mexico State University, 1974.

Eberts, Paul R. "A Theoretical Perspective Toward an Action-Oriented Model of Community Change and Development, unpublished paper presented to the joint meetings of the Western Agricultural Economics Research Council and the Western Social Research Advisory Council, San Francisco, CA, Octoder 13-14, 1971.

Edwards, Mike W. "Should They Build a Fence Around Montana?", National Geographic, 149(5), 1976, 614-650.

Energy Development Consultants, Inc. 0il Shale in the United States, Golden, C0: Energy Development Consultants, 1980.

England, J. Lynn, and Stan L. Albrecht. "Boomtowns and Social Disruption," Rural Sociology, 19(2), 1984, 230-246.

Federation of Rocky Mountain States. Energy Development in the Rocky Mountain Region: Goals and Concerns, Denver, CU: Federation of Rocky Mountain States, 1975.

Feldman, D. "Boomtown Women," Environmental Action, 11(11), 1980, $16-20$. 
Finsterbusch, Kurt. "Boomtown Disruption Thesis: Assessment of Current Status," Pacific Sociological Review, 25(July), 1982, 307-322.

Finsterbusch, Kurt. "Commentary," Pacific Sociological Review, 25, 1982, 307-323.

Finsterbusch, K., and C. P. Wolf, eds. Methodology of Social Impact Assessment, Stroudsburg, PA: Hutchinson Ross, 1981.

Finsterbusch, K., and A. B. Motz. Social Research for Policy Decisions, Belmont, CA: Wadsworth Publishing Company, 1980.

Finsterbusch, K. "A Policy Analysis Methodology for Social Impacts," Journal of the international Society for Technology Assessment, 1(March), 1975, 5-15.

Finsterbusch, K. "Demonstrating the Value of liini Surveys in Social Research," Social Methods and Research, 5, 1976, 117-136.

Finsterbusch, K. "The Mini Survey: An Underemployed Research Tool," Social Science Kesearch, 5 (March), 1976, 81-93.

Finsterbusch, Kurt. "State of the Art in Social Impact Assessment," Environment and Behavior, 17(2), 1985, 193-221.

Finsterbusch, K. Understanding Social Impacts: Assessing the Effects of Public Projects, Beverly Hills, CA: Publications, Inc., 1980.

Fisher, J. C., and R. H. Pry. "A Simple Substitution Model of Technological Change," Report 70-C-215, General Electric Company, Research and Development Center, Schenectady, NY.

Fitzsimmons, D., L. Stuart, and P. Wolf. Social Assessment Manual: A Guide to the Preparation of the Social We11-Being Account, Washington, DC: U.S. Bureau of Reclamation, 1975.

Fletcher, W. Wendell. Energy Facilities Siting and Land Use Policy: An Analysis of State Laws and Federal Legislative Proposals, Masters thesis, State University of New York, Syracuse, NY, 1977.

Fliegel, Frederick C. "A Comparative Analysis of the Impact of Industrialism or Traditional Values," Rural Sociology, 41(4), 1976, 431-451.

Flynn, C. B., and J. H. Flynn. "The Group Ecology Method: A New Conceptual Design for Social Impact Assessinent," Impact Assessment Bulletin, 1(4), 11-19.

Foster, M. I. "Socioeconomic Analysis of the Hartsville Nuclear Plant," AIF Conference on Land Use and Nuclear Facility Siting: Current Issues, Denver, CU, July 20, 1976. 
Francis, Mark. "Urban Impact Assessment and Community Involvement: The Case of the John Fitzgerald Kennedy Library," Environment and Behavior, $\underline{I}(3), 1975,373-404$.

Freisema, H. P., and P. J. Culnane. "Social Impacts, Politics, and the Environmental Impact Statement Process," National Resources Journa l, 16(Apri1), 1976, 339-356.

Freudenberg, William R. "The Social Impact of Energy Boom Development on Rural Communities: A Review of Literature and Some Prediction," presented at the American Sociological Association, San Francisco, CA, annual meeting, August 1978.

Freudenberg, William R. "A Social Impact Analysis of a Rocky Mountain Energy Boomtown," presented at the American Sociological Association annual meeting, San Francisco, CA, August 1978.

Freudenberg, William R. "People in the Impact Zone: The Human and Social Consequences of Energy Boomtown Growth in Four Western Colorado Communities," Ph.D. thesis, Yale University, New Haven, CT, 1979 .

Freudenberg, William R. "The Effects of Rapid Population Growth on the Social and Personal Well-Being of Boomtown Residents,"; presented at the Western Rural Development Center Conference, Scottsda7e, AZ, February 26-27, 1980.

Freudenberg, William R. "Women and Men in an Energy Boomtown, Adjustment, Alienation, and Adaptation," Rural Sociology, 46 (Summer), 1981, 220-224.

Freudenberg, William R., and Kenneth M. Keating. "Applying Sociology to Policy: Social Science and the Environmental Impact Statement," Rural Sociology, 50(4), 1985, 578-605.

Freudenberg, William R. "Boomtown's Youtn," presented at the Rural Sociological Society annual meeting, Burlington, VT, August 1979.

Freudenberg, William R., Linda M. Bacigalupi, and C. Tandoll-Young. "Mental Health Consequences of Rapid Community Growth: A Report from the Longitudinal Study of Boomtown Mental Health Impacts," Journal of Health and Human Resources Administration, 4(Winter), 334-352.

Fuguitt, Glen V. "The Places Left Behind: Population Trends and Policy for Rural Anierica," Rural Sociology, 36(4), 1971, 449-470.

Funk, James. "Keynote Address: Energy and Eastern 0il Shale," Proceedings of the 1981 Eastern 0il Shale Symposium, University of Kentucky, Institute of llining and Minerals Research, 1982, Lexington, $\mathrm{KY}$. 
Garner, J. F., and Timothy O'Riordan. "Environmental Impact Assessment in the Context of Economic Recession," The Geographical Journal, 3(Nov), 1982, 343-361.

Garrison, Charles B. "The Impact of New Industry: An Application of the Economic Base Multiplier to Small Rural. Areas," Land Econoinics, XLVIII(4), 1972, 329-337.

Garrison, C. B. "The Impact of New Industry on Local Government Finances in Five Small Towns in Kentucky," Agricultural Economics Report No. 191, Washington, DC: Economic Research Service, U.S. Department of Agriculture, 1970.

Garrison, L. B. "New Industry in Small Towns: The Impact on Local Government," National Tax Journa1, 24(4), 1971, 493-500.

Gilluly, Richard H. "A Home on the Range for a Vast Industry," Science News, 101(10), 1974, 145-160.

Gilmore, J. S. "Boomtowns May Hinder Energy Resource Development," Science, 191(13), 1976, 535-540.

Gilmore, J. S., and M. K. Duff. Boomtown Growth Management: A Case Study of Rock Springs, Green River Wyoming, Boulder, CO: Westview Press, 1975.

Gilmore, J. S., R. E. Giltner, D. C. Coddington, and M. K. Duff. "Factors Influencing an Area's Ability to Absorb a Large Scale Processing Complex," Washington, DC: Energy Research Development Administration, 1975.

Gilmore, J. S., D. Hammond, K. Moore, J. Jonnson, and D. C. coddinglon. Sociueconomic Ilipact of Power Plants, Palo Alto; CA: Electric Power Research Institute, 1982.

Gilmore, J. S., K. D. Moore, D. M. Hammond, and D. C. Coddington. Analysis of Financing Problems in Coal and 0il Shale Boom Towns, Washington, DC: Federa1 Energy Adininistration, 1976.

Gold, R. L. A Comparative Case Study of the. Inpact of Coal Development on the Way of Life of People in the Coal Areas of Eastern Montana and Northeastern Wyoming, Denver, CO: Northern Great Plains Resource Prograin, 1974.

Gold, R. L, "How Southeastern Montanans View the Coal Development Issue," Western Wildlands, 16, 1975.

Goldberg, D., V. R. Rao, and N. K. Namboodiri. "A Test of the Accuracy of Ratio Correlation Population Estimates," Land Economics, 40, 1964, 100-102.

Goidstein, S., and K. Mayer. "Migration and the Journey to Work," Soctal Forces, 42(4), 1964, 472-481. 
Gordus, Jeannne Prial, Paul Jarley, and Louis Ferman.
and Economic Dislocation, Kalamazoo, MI: Institute, 1981.

Gould, L. C. "Social Science Research on 'The Energy Boomtown," Social Science Energy Review, 1(Winter), 1978, 8-23.

Graber, E. E. "Newcomers and 01dtimers: Growth and Change in a Mountain Town," Rural Sociology, 39(4), 1974, 504-514.

Gramling, Bob, and Sarah Brabant. "Boomtowns and Offshore Energy Impact Assessment: The Development of a Comprehensive Mode1," Sociological Perspectives, 29(2), 1986, 177-201.

Great Plains Agricultural Council. "Effects of Energy Development on Agriculture and Rural Communities in the West," prepared for the Western Governors, Lincoln, NE: Great Plains Agriculture Council, 1975.

Grimes, Michael D., Jeanne J. Deville, and Elizabeth G. Leonard. "Critical Issues in the Analysis of Social, Economic, and Cultural Impacts of Energy Extraction and Development of Local Areas," Journal of the Community Development Society, 15(1), $1984,45-58$.

Halstead, J. M, R. A. Chase, S. H. Murdock, and F. L. Leistritz. Socioeconomic Impact Management: Design \& Implementation, Boulder, CO: Westview Press, 1984.

Hawkins, Micnael R. "Dynamic Needs Assessment: An Example," in The Booin Town: Problems and Promises in the Energy Vortex, Davenport, Joseph, III, and Judith Ann Davenport, eds.; University of Wyoming, Laramie, WY.

Hayen, Roger L., Jay R. Hamann, and Timothy J. Keaveny. Environmenta 1 Impact Statements: A Computer-Based Planning Approach, Larainie, WY: University of Wyoming, 1975.

Hayen, R. L.., and G. L. Watts. "A Description of Potential Socioeconomic Impacts from Energy-Related Developments on Campbell County, Wyoming," Wasnington, DC: U.S. Department of Interior, 1975.

Hecox, W. E. "Colorado Energy Resource Development Plan: A Decision Assistance Tool," in Computer Models and Forecasting Economic Impacts of Growth and Development, McDonald, Jim, ed., Edmonton, Canada: University of Alberta, 1981.

Hecox, W. E. "Projections of Northwest Colorado Energy Development and Associated Impacts Through the Mid-1990's: A Preliminary Regional Perspective," Executive Director's Office, Colorado Department of Natural Resources, Denver, CO, 1980. 
Hecox, W. E. "Shaping a Colorado Consensus on Appropriate Synfuels and Energy Development: The Challenge, the Context, and a Suggested Policy Response," Executive Director's Office, Colorado Department of Natural Resources, Denver, C0, 1981.

Hecox, W. E., and L. A. Pook. "A Survey and Analysis of Existing Information on Built Environment and Socioeconomic Impacts in Northwest Colorado," prepared for Northwest Colorado Wildlife Consortium, Southwest Studies Program, Colorado College, Colorado Springs, C0, 1982.

Hecox, Walter E. "Regional Management of the Energy-Environment Interface: Techniques Applied to Colorado 0il Shale Development," Energy-Environment Interface Management, 13(3), 1983-1981, 267-278.

Heer, J. E., Jr., and D. J. Hagerty. Environmental Assessments and Statements, New York: Van Nostrand, Reinholt Co., 1977.

Helgeson, D. L., and M. J. Zink. "A Case Study of Rural Industrialization in Jamestown, North Dakota, Agricultural Economic Keport 95," Fargo: Agricultural Experinenl Staliun, Department of Agricultural Economics, North Dakota State University, 1973.

Hoftiman, Wayne Lee. "Coping with Boom and Bust: The Colony 0il Snale Project," Natural Resource Development, 2 (1), 1983, 29-58.

Humphrey, C., and F. Buttel. Environment, Energy, and Society, Belmont, CA: Wadsworth Publishing Company, 1982.

Hunter, A. "The Loss of Community: An tmpirical lest Ihrough Replication," American Sociological Review, 40, 1975, 537-552.

Ingraham, Elizabeth Wright. "Lead Time for Assessing Land Use: A Case Study," Science, 194(4260), 1976, 17-23.

Institute of Applied Research. Anticipated Effects of Major Coal Development, Bozeman, MT: Institute of Applied Researcin, 1975.

Isard, W., C. Choquill, J. Kissin, R. Seyfarth, and R. Tatlock. Ecologic-Economic Analysis for Regional Development, New York: The Free Press, 1972.

Jirovee, Ronald. "Preparing a Boom Town for the Impact of Rapid Growth," in Booin Towns and Human Services, Davenport, Judith A., and Joseph Davenport III, eds.; Laramie, WY: University of Wyoming.

Jobes, Patrick C. "Small Rural Community Responses to Coal Development," Sociology and Social Research, 70(2), 1986, 173-177. 
Jocobsen, Sally. "Science and Public Affairs," Bulletin of the Atomic Scientists, 29(4), 1973, 37-43.

Joseph, Alvin M., Jr. "Agony of the Northern Plains," Audubon, 75(4), 1973, 68-101.

Kelly, John R. "Planned and Unplanned New Town Impacts: Applying a Method," Environment and Behavior, I(3), 1975, 330-357.

Kentucky Department of Commerce. Kentucky Economic Statistics, Lexington, $K Y, 1981$.

Keyfitz, Nathan. "Can Knowledge Improve Forecasts?", Population and Developinent Review, 8, 1982, 729-751.

Knapp, John L., T. Windsor Fields, and Robert T. Jerome, Jr. "A Survey of State and Regional Econometric Models," Charlottsville, VA: Taylor Murphy Institute, University of Virginia, 1978.

Kneese, A. V., and F. L. Brown. The Southwest Under Stress: National Resource Development Is sues in a Regional Setting, Baltimore, MD: Johns Hopkins University Press, 1981.

Konrs, E. V. "Social Consequences of Boomtown Growth in Wyoming." presented at the Annual Meeting of the Southwestern and Rocky Mountain Section, American Association for the Advancement of Science, Laramie, WY, April 1974.

Koulet, K. G. "Assessing Energy Uncertainties: Projections of Northwest Colorado Enerqy Development and Associated Impacts Through the Year 2,000," Colorado Energy Resource Management Program, Executive Director's Office, Colorado Department of Natural Resources, Denver, C0, 1983.

Koulet, K. G. "Preliminary Production Projections Using CRIS," Executive Director's Office, Colorado Department of Natural Resuurices, Denver, C0, 1983.

Krannich, Richard. "Socioeconomic Impacts of Power Plant Developments on Nonmetropolitan Communities," Rural Sociology, 46(1), 1981, 128-142.

Krebs, Girard. "Technological and Social Impact Assessment of Resource Extraction," Environment and Behavior, $7(3), 1975$, $307-329$.

Krutilla, J. V., and A. C. Fisher. "The Regional Economic and Fiscal Impacts of Energy Resource Development: A Case Study of Northern Great Plains Coa1," Wasnington, DC: Resources for the Future, 1976.

Krutilla, John W., Anthony C. Fisher, and Richard E. Rice. "Economic and Fiscal Impacts of Coal Development: Northern Great Plains," Baltimore, MD: Johns Hopkins University Press, 1978. 
Lakshmanan, T. R., and. Samuel J. Ratick. "Integrated Models for Economic-Energy-Environment Impact Analysis," in Economic-Environmental-Energy Interactions, Boston, MA: Martinus Ni jhoff, 1980.

Lamm, R. D., and M. McCarthy. "The Angry West: A Vulnerable Land and Its Future," Boston, MA: Houghton-Mifflin Co., 1982.

Lantz, A., and R. L. Mckeown. "Rapid Growth and the Impact on Quality of Life in Rural Communities: A Case Study," Denver Research Institute, University of Denver, September 1977.

Lantz, A. E., and R. L. McKeown. "Social Psychological Problems of Women and Their Families Associated with Rapid Growth," in Energy Resource Development: Intermountain West, U.S. Commission on Civil Rights, Washington, DC: U.S. Government Printing Uffice, 1979.

Lantz, Sackett, Karen Alma, and Joseph Halpern. "Al cohol -- Related Problems in Rapidly Growing Communities," in The Boom Town: Problems and Promises in the Energy Vortex, Davenport, Joseph, III, and Judith Ann Davenport, eds.; Laramie, WY: University of Wyoming, 1980.

Larson, 0laf F. "Values and Beliefs of Rural People," in Rural USA: Persistence and Change, Ford, Thomas, R., ed.; Ames, IA: State University Press, 1978.

Larson, Sharon. "The Elderly: Victims of the Energy Venture," in The Boom Town: Problems and Promises in the Energy Vortex, Davenport, Joseph, III, and Judith Ann Davenport, eds.; Laramie, WY: University of Wyoming, 1980.

LeBus, Margaret M. "A Preliminary Assessment of the Potential for Adverse Social and Economic Impact from Shale Development in the Kentucky Knobs Counties," Proceedings of the 1983 0il Shale Symposium, University of Kentucky, Institute for Mining and MineraT Research, IMMR83/089, 1984, 287-296.

Lee, Everett S., and Harold F. Goldsmith, eds. Population Estimates: Methods for Small Area Analysis, Beverly Hills, CA: Sage, 1982.

Lee, Roger D. "An Analysis of State Energy Impact Mitigation Programs in Colorado, Utah, Montana and Wyoming," Journal of Energy Law and Policy, 3, 1983, 281-328.

Leholm, Arlen G., F. Larry Leistritz, and Thor A. Hertsguard. "Fiscal Impact of New Industry in a Kural Area: A Coal Gasification Plant in Western.North Dakota," Regional Science Perspectives, 6 , 1976, 40-56. 
Leholm, A. G.,.,F. L. Leistritz, and J. W. Wieland. "Profile of North Dakota's Coal Mine and Electric Power Plant Operating Work Force," Agricultural Economics Report No. 100, Fargo, ND: Agricultural Experimental Station, 1975.

Leholm, A. G., F. L. Leistritz, and T. A. Hertsgaard. "Profile of North Dakota's Electric Power Plant Construction Work Force," Agricultural Economics Statistic Service, Issue 22, Fargo, ND: Agricultural Experimental Station, 1976.

Leistritz, F. L., J. M. Halstead, R. A. Chase, and S. H. Murdock. "Socioeconomic Impact Management: Programme Design and Implementation Considerations," Minerals and the Environment, $\underline{4}$, 1982, 141-150.

Leistritz, F. L., and S. H. Murdock. "Socioeconomic Impact Monitoring Systems: A Review and Evaluation," Journal of Environmental Management, 15, 1982, 333-349.

Leistritz, F. Larry, and Steve H. Murdock. Socioeconomic Impacts of Resource Development: Methods of Assessment, Boulder, C0: Westview Press, 1981.

Leistritz, F. L., S. H. Murdock, N. E. Toman, and T. A. Hortsgaard. "A Model for Projecting Localized Economic, Demographic, and. Fiscal Impacts of Large-Scale Projects," Western Journal of : Agricultural Economics, 4 (2), 1979, 1-16.

Leistritz, F., R. Cnase, B. Ekstrom, G. Knapp, L. Huskey, S. Murdock, and $M$. Scott. "Challenges to Socioeconomic Impact Modeling: Lessons from the Alaska OCS Program," Journal of Environmental Management, 21(4), 1985, 301-319.

Lejstritz, F. L., S. H. Murdock, and R. A. Chase. "Socioeconomic Assessment Mode1s: Review and Evaluation," Impact Assessment Bulletin, 1, 30-43.

Lesius, Piet J. J., Frederick Muller, and Peter Nijkam. "An Interregional Policy Model for Energy-Economic-Environmental Interactions," Regional Science and Urban Economics, 10(August), $1980,343-370$.

Lesius, Piet J. J., Frederick Muller, and Peter Nijkam. "Operational Methods for Strateglc Envirurmiental and Energy Policies," in Economic-Environmental-Energy Interactions, Boston, MA: Martinas Nijhoff, 1980.

Lewis, A. E. Uil Snale: A Framework for Development, Lawrence Livermore Laboratory, Livermore, CA, 1980.

Lewis, Chris, and Stan Albrent. "Attitudes Toward Accelerated Urban Developinent in Low Population Areas." Growth and Change, 8(1), $1977,22-28$. 
Lillydah1, J., E. Moen, E. Boulding, K. Yount, S, Scott-Stevens, and I. Gallon. Quality of Life, Expectations of Change, and Planning for the Future in an Energy Production Community, Boulder, Cu: University of Colorado, 1982.

Lindauer, R. "Solutions to the Economic Impacts of Large Mineral Development on Local Governments," in Federation of Rocky Mountain States: Energy Development in the Rocky Mountain Region, Goals and Concerns.

Little, R. L. "Some Social Consequences of Boomtowns," North Dakota Law Review, 53, 1977, 401-425.

Little, R. L., and S. B. Lovejoy. "Employment Benefits from Rural Industrialization," Lake Powcll Research Project Dulletin, 50, Logan, UT: Utah State University, $197 \%$.

Little, Ronald L., and Richard S. Krannich. "Organizing for Local Control in Rapid Growth Communities," in Coping with Rapid Growth in Rural Communities, Weber, Bruce, and Robert Howe11, eds.; Boulder, CO: Westview Press, 1982.

Lonsdale, R. E., and H. L. Seyler, eds. Noninetropolitan Industrialization, New York: Wiley, 1979.

Lovejoy, S. B. "Employment Predictions in Social Impact Assessment: An Analysis of Some Unexplored Variables," Socioeconomics for Planned Science., 17, 198.3, 87-9.3.

Lovejoy, S. B., and R. S. Krannich. "Rural Development: A Critical Perspective," The Rural Sociologist, 1 (March), 1981, 84-91.

Lovejoy, Stephen B., and Richard S. Krannich. "Rural Industrial Development and Domestic Dependency Relations," Rural Sociology, 47(Fal1), 1982, 475-495.

Lowe, Theresa, Donald Pittenger, and John Walker. "Making the Housing Unit Population Estimation Method Work: A Progress Report," presented at the Population Association of America annual meeting, St. Louis, MO.

Markey, K. "The Costs of dil Shale," Friends of the Earth, Denver, C0, 1979.

Markusen, A. "Class, Rent and Sectoral Conflict: Uneven Development in Western U.S. Boomtowns," Review of Radical Political Economics, 10(3), 1978, 117-130.

Marston, Ed. "What Happened to the 0il Shale Towns," Planning, 50(5), 1984, 25-29.

Massey, Garth. Building a Power Plant: Newcolners and Social Impact, Center for Studies of Metropolitan Problems, NIMH, Rockvilie, MD, 1978. 
Massey, Garth. "Critical Dimensions in Urban Life: Energy Extraction and Community Collapse in Wyoming," Urban Life, 9(July), 1980, 187-199.

Mckeown, R. L., and A. E. Lantz. "Rapid Growth and the Impact on Quality of Life in Rural Communities: A Case Study," Glenwood Springs, C0: Western Regional Mental Health Center, 1977.

McMahan, R. L., and P. B. Bennet. "Energy Activity in the West," Western Governor's Policy Office, Denver, CU, 1981.

Meale, R., B. Ingelorigtson, and K. Branch. "Mining Impacts on Wage Rates in Other Employment Sectors," Montana Department of State Lands and the U.S. Office of Surface Mining and Reclamation, Helena, MT, 1983.

Meeker, D. "Rapid Growth from Energy Projects: Ideas for State and Local Action," Washington, OC: Department of Housing and Urban Development, Office of Community Planning and Development, 1976.

Meidinger, Errol E., and Allan Schnaiberg. "Social Impact Assessment as Evaluation Research: Claimants and Claims," Evaluation Review, 4, 1980, 507-535.

Meidinger, Errol.E., and William R. Freudenburg. "The Legal Status of Social Impact Assessment: Recent Developments," Environmental Sociology, 34, 1983, 30-33.

Miernyk, W. H. "Local Labor Market Effects of New Plant Locations," in Regional Economics, Cambridge, MA: Harvard University Press, 1971.

Miernyk, W. H. "Comments on Recent Developments in Regional Input-Output Analysis," International Regional Science Review, 1 , $1976,47-55$.

Miernyk, William H. Regional Analysis and Regional Policy, Cambridge, MA: Velgeschlager, Cann and Hain, 1982.

Miller, Stephen $H . \quad$ "Potential Economic Impact of Uil Shale Commercialization in Fleming County, Kentucky," 1981 Eastern 0il Shale Symposium Proceedings, University of Kentucky, Institute of Mining and Minerals Research, IMMR 821066, 1982, 291-302.

Moore, Keith D., and John S. Gilmore. "Socioeconomic Impacts of Western Energy Resource Development: St.ate of the Art Limitations," Integrated Impact Assessment, Rossini, and Porter eds.; Boulder, CO, Westview Press, SIA Series, \#8, Denver Research Institute and Research Planning Associates, 1983.

Mountain West Research, Inc. "Construction Worker Profile," Washington, DC: 01d West Regional Commission, 1975. 
Mountain West Research-Southwest, Inc. "Description of the Mountain West Planning and Assessment System," Mountain West Research, .Tempe, AZ, 1982.

Mountain West Research-Soutnwest, Inc. "Technical Documentation and Summary," Cumulative Impacts Task Force, Denver, C0, 1982.

Moxiey, R. L. "Vertical Assistance, Population Size and Growth in the Context and Results of Community Civil Action," Journal of the Community Development Society, 16(1), 1985, 57-74.

Murdock, S. A. "The Potential Role of the Ecological Framework in Impact Analyses," Rural Sociology, 44, 1979, 543-565.

Murdock, S. H., and F, L, Leistritz. Energy Development in the Western United States: Impact on Rural Areas, New York: Praeger Publishers, 1979.

Murdock, Steve H., Larry Leistritz, and Eldon C. Schriner. "Migration and Energy Developments: Implications for Rural Areas in the Great Plains," in New Directions in Urban-Rural Migration, Brown, D., and J. Wardwel $\overline{r, \text { eds.; Hew York: Academic Press, } 1980 .}$

Murdock, Steve H., F. Larry Leistritz, and Eldon C. Schriner. "Local Demographic Changes Associated with Rapid Growth," in Coping with Rapid Growth in Rural Communities, Weber, B., and R. Howe11, eds.; Boulder, CU: Westview Press, 1982.

Murdock, S. H., F. L. Leistritz, R. R. Hamm, and S. S. Hwang. "An Assessment of Socioecononic Assessments: Utility Accuracy and Policy Considerations," EIA Review, 3, 1982, 333-350.

Murdock, S. H., and F. L. Leistritz. "Commentary," Pacific Sociological Review, 25, 1982, 357-366.

Murdock, S. H., and E. L. Schriner. "Community Service Satisfaction and Staqes of Community Development: An Examination of Evidence from Impacted Communities," Journal of the Community Development Society, 10(Spring), 1979, 109-124.

Murdock, Steve $H_{.}$, and Eldon C. Scinriner. "Structural and Distrijutional Factors in Community Development," Rural Sociology, 43(3), 1978, 426-449.

Murdock, S. H., J. S. Wieland, and F. L. Leistritz. "An Assessment of the Validity of the Gravity Model for Predicting Community Settlement Patterns in Rural Energy Impact Areas in the West," Land Economics, 54, 1978, 461-471.

Myler, Glade A. "Mitigating Boom Town Effects of Energy Development: A 1982 Survey," Journal of Energy Law and Policy, 2., 1982, 211-235.

Namboodiri, N. K. "On the Ratio-Correlation and Related Methods of Subnational Population Estimation," Demograpny, 9, 1972, 443-453. 
Nellis, Lee. "What Does Energy Development Mean for Wyoming?", Human Organization, 33, 1974, 229-238.

Nesbitt, Paul D., Barbara Lovan, and John Mays. "Socio-Economic Impacts: Validity of Evidence from the Coal Mining. Industry in Kentucky," Eastern 0il Shale Symposium Proceedings, University of Kentucky, Institute of Mining and Minerals Research, IMM R82/066, $1981,333-342$.

0'Hare, W. P. "Report on a Multiple Regression Method for Making Population Estimates," Demography, 13, 1976, 369-379.

vil Shale. "A Technology and Policy Primer," Colorado Energy Research Institute and Colorado School of Mines Research Institute, 1982, Denver, Co.

01 son, Judith K. "Needs Assessment and Program Evaluation in Impacted Communities," in The Boom Town: Problems and Promises in the Energy Vortex, Davenport, Joseph, III, and Judith Ann Davenport, eds.; Laramie, WY: University of Wyoming, 1982.

Orloff, N. The Environmental Impact Statement Process: A Guide to Citizen Action, Wasnington, DC: Information Resources Press, 1978.

Paden, D. D. Krist, and M. Seaton. "Impact of Industrial Development on Selected Iowa Communities," Final Report, Ames, IA: Development Committee, 1972.

Perry, Charles S. "Coal Production and Socioeconomic Development in Southern Appalachia: The Case of Eastern Kentucky," Social Indicators Research, 11, 1982, 193-205.

Perry, C. S., and W. Bauder. "Equality, Economic Resources, and Structural Differentiation: Dimensions of Development in the Northeast U.S.," Social Indicators Research, 8, 1980, 327-340.

Perry, Cnarles S. "Making Coal Pay: The Conversion of Natural Resources to Economic Resources in Southern Appalachia: The Case of Eastern Kentucky," Social Indicators Research, 16, 1985, 97-111.

Peterson, G., and R. Gemme11. "Social Impact Assessment: Comments on the State of the Art," in Methodology of Social Impact Assessment, Finsterbusch, K., and C. P. Wolf, eds.; Stroudsburg, PA: Dowden, Hutchinson, and Ross, Inc., 1977.

Pilisuk, M., and C. Froland. "Kinship Social Networks, Social Support and Health," Social Science and Medicine, 12, 1978, 273-280.

Pook, L. "Operationalization Plan for Installation of the Initial GIS at the Department of Natural Resources," CRIS issue paper \#4, Executive Director's Office, Colorado Department of Natural Resources, Denver, CO, 1980. 
Pook, L. "Recommendations for a Resource Information System for the Department of Natural Resources - State of Colorado," CRIS Issue paper \#3, Executive Director's office, Colorado Department of Natural Resources, Denver, C0, 1979.

Pribble, L. W. Planning and Construction of Rernote Communities, New York: John WiTey, 1984.

Pulver, G. L. "A Theoretical Framework for the Analysis of Community Economic Development Policy Options," in Nonmetropolitan Industrial Growth and Community Change, Summers, G. F., and $A_{\text {. }}$ Selvik, eds.; Lexington, MA: Heath, 1979.

Purse11, D. E. "Improving Population Estimates with the Use of Dummy Variahles." Demngraphy. 7. 1970, 87-91.

Reynolds, R. R., K. P. Wilkinson, J. G. Thompson, and L. M. Ostresh. "Problems in the Social Impact Assessment Literature Base for Western Energy Development Communities," Impact Assessment Bulletin, 1(Summer), 1982, 44-59.

Richards, R. 0. "When Even Bad News is Not so Bad: Local Control Over Outside Forces in Community Development," Journal of the Community Development Society, 15(1), 1984, 75-85.

Rocky Mountain 0il and Gas Association. "Committee on 0il Shale Workforce Estimates," Rocky Mountain 0il and Gas Association, Denver, C0, 1983.

Rosenberg, Harry. "Improving Current Population Estimates Through Stratification," Land Economics, 44, 1968, 331-338.

Rossini, Frederick $A_{i}$, and Alan $L_{\text {: }}$ Portcr. Intcgrated Impact Assessment, Boulder, C0: Westview Press, 1983.

Rubin, Barry M. "An Econometric Impact Analysis Model for Large-Scale Energy Development Projects: Synthetic Fuels Development in the Illinois Coal Basin," Grant No. SES-81-07355, Wasnington, DC: Final Report to the National Science Foundation, 1984.

Rubin, Barry M., and Barry D. Solomon. "Economic and Fiscal Impact Analysis of Energy Development Projects: Coal Liquefaction in the Illinois Basin," Socio-Economic Planning Sciences. 17 (January), 1983, 11-20.

Russel, E., and S. Colby. "The Colorado Cumulative Impacts Task Force, Division of Commerce and Development," Colorado Department of Local Government, Denver, CU, 1982. .

Savatsky, Pamela Dee. "A Legal Rationale for the Sociologists' Role in Researching Social Impacts," in Social Impact Assessinent, Wolf, C. P., ed.; Stroudsburg, PA: Powden, Hutchinson, and Ross, 1974. 
"Schnaiberg, A. "Social Syntheses of the Societal-Environmental Dialectic: The Role of Distributional Impacts," Social Science Quarterly, 56(June), 1975, 5-20.

Schweitzer, M., S. A. Carnes, E. J. Soderstrom, and R. B. Braid. "Synthetic Fuel Development: Potential Socioeconomic Impacts of Single and Multiple Projects," Energy Policy, 11(4), 1983, 333-345.

Schwing, R. C., and W. A. Albers, Jr., eds. Societal Risk Assessment: How Safe is Safe Enough?, New York: Prenum, 1980.

Scrimegeour, Don. "Coping with the 0il Shale Boom," Planning, 46(8), $1980,19-21$.

Seiler, L. H., arid G. F. Summers. "Corporate Involvement in Community Affairs," Sociological Quarterly, 20, 1979, 375-386.

Seiple, W. Ray. "New Approach to Site Selection Studies," Journal of the Power Division, 100(P01), 1974, 63-69.

Sewell, W. R. D. "Broadening the Approach to Evaluation in Resources Management Decision Making," Journal of Environmental Management, 1, 1973, 33-60.

Shaffer, R. E. "The Net Economic Impact of New Industry on Rural Communities in Eastern OKlahoma," Ph.D. thesis, OKlahoma State University, Stillwater, OK, 1972.

Shaffer, R. E. "Rural Industrialization: A Local Income Analysis," Soutnern Journal of Agricultural Economics, 6(1), 1974, 97-102.

Sharkansky, I., and R. I. Hofferbert. "Dimensions of State Politics, Economics and Public Policy," American Political Science Review, 63, $1969,867-879$.

Snields, Mark Q. "Social Impact Studies: An Expository Analysis," Environment and Behavior, $7(3), 1975,265-284$.

Shillington, T, H. "Rapid Growth Issues in Western 0il Shale Development: Uncertainty and Impact Mitigation," Economic Research Service, AGES 811117, Wasnington, DC: U.S.D.A., December 1981.

Smit, Barry, and Tom Johnston. "Public Policy Assessment: Evaluating Objectives of Resource Policies," The Professional Geographer. $35(2), 1983,172-178$.

Smith, Stanley K., and Burt B. Lewis. "Some New Techniques for Applying the Housing United Method of Local Population Estimation," Demography, 17, 1980, 329-339.

Solomon, Barry D., and Barry M. Rubin. "Environmental Linkages in Regional Econometric Models: An Analysis of Coal Development in Western Kentucky," Land Economics, 61(1), 1985, 43-57. 
Stenehjem, Erik J., and James E. Metzger. "A Framework For Projecting Employment and Population Changes Accompanying Energy Development," Phase I, Argonne National Laboratory, Argonne, IL, 1976.

Stenehjem, E., and J. Metzer. "Socioeconomic Implications of the National Energy Plan: Comparative Social Costs of Increased Coal Production to 1985," (draft), Agronne, IL: Regional Studies Program, Argonne National Laboratory, 1977.

'Stenenjem, E. J., and E. H. Al len. "Socioeconomic and Institutional Constraints to Energy Development," American Behavioral Scientist, 22, 1978, 213-236.

Stewart, J. Q. "An Inverse Distance Variation for Certain Social Influences," Science, $93(2), 1941,89-90$.

Stinson, T. F., and S. W. Voelker. "Coal Development in the Northern Great Plains: The Impact on Revenues of State and Local Governments," Agricultural Economic Report 394, Washington, DC: U.S. Department of Agriculture, 1978.

Stinson, T. F., L. D. Bender, and S. W. Voelker. "Northern Great Plains Coal Mining: Regional Impacts," Agriculture Information Bulletin Number 452, Economic Research Service, U.S.D.A., July, $1982,36$.

Summers, Gene F. "Rural Community Vevelopment," Annual Reviews of Sociology, 12, 1986, 347-371.

Summers, Gene F. Large Industry in a Rural Area: Demographic, Economic, and Social Impacts, Madison: Department of Rural Sociology, University of Wisconsin, 1973.

Summers, G. F. "Industrial Development in Rural Anerica," Journal of the Community Development Society, $8,1977,6-18$.

Summers, Gene F. "Industrialization," in Rural Society in the U.S.: Issues for the 1980s, Dillman, D. A., and D. J. Hobbs, eds.; Boutder, CO: Westview Press, 1982.

Summers, G. F., and A. Selvik, eds. Non-Metropolitan Industrial Growth and Community Change, Lexington; MA: Heath, 1979.

Summers, G. F., and K. Branch. "Human Responses to Energy Resource Development," in Energy Resource Communities, Summers, G. F., and A. Selvik, eds.; Madison, WI: MJM, 1982.

Suminers, G. F., ed. Technology and Socjal Change in Rural Areas, Boulder, CU: Westview Press, 1983.

Summers, G. F., and K. Branch. "Economic Development and Community Social Change," Annual Review of Sociology, 10, 1984, 141-166. 
Summers, G. F., S. D. Evans, F. Clemente, E. M. Beck, and J. Minkoff. Industrial Invasion of Nonmetropolitan America: A Quarter Century of Experience, New York: Praeger, 1976.

Thompson, J. G. "The Gillette Syndrome: Myth or Reality," Wyoming Issues, 2(Spring), 1979; 30-35.

Thompson, J. G., A. L. Blevins, Jr., and G. L. Watts. "Socioeconomic Longitudinal Monitoring Project," Final Report, Volume 1, Summary, Laramie: Center for Urban and Regional Analysis, University of Wyoming, 1979.

Thompson, J. G.,. K. P. Wilkinson, L. M. Ustresh, and R. R. Reynolds, Jr. "Social Disruption and Rapid Community Growth: An Explication of the Boomtown Hypotheses," presented at the Annual Meeting of the Rural Sociological Society, August 1980.

Thompson, James G., and Audie L. Blevins. "Research Note: Attitudes Toward Energy Development in the Northern Great Plains," Rural Sociology, 48(1), 1983, 148-158.

Toman, N. E., N. L. Dalstead, A. G. Leholm, R. C. Coon, and F. L. Leistritz. "Economic Impacts of Construction and Operation of the Coal Creek Electrical Generation Complex and Related Mine," Fargo, ND, Agricultural Experiment Station, 1976.

Toman, N. E., A. G. Leholm, N. L. Dalstead, and F. L. Leistritz. "A Fiscal Impact Model for Rural Industrialization," Western Journal of Agricultural Economics, 1, 1976, 242-247.

Toole, Ross K. The Rape of the Great Plains, Boston: Little, Brown and Company, 1976.

Urban Studies Center. How Many Kentuckians: Population Forecasts, University of LouisvitTe, LouisvilTe, KY, 1983.

Urban Studies Center. Migration in Kentucky: Analysis and Net Migration Estinates: 1970-80, University of Louisville, Louisvil1e, KY, 1983.

U.S. Congress. "Office of Technology Assessment, An Assessinent of 0il Shale Technologies," Washington, DC: U.S. Government Printing uffice, 1980.

U.S. Department of Energy. Synthetic Fuels and the Environment: An Environmental and Kegulatory Impacts Analysis, Washington, IJC: U.S. Government Printing Office, 1980.

U.S. Department of Interior. Draft Environmental Impact Statement on the Federal dil Shale Management Program, Wasnington, DC: Government Printing Office, 1983. 
U.S. Department of Interior. Final Supplemental Environmental Impact Statement for the Prototype 0il Shale Leasing Program, Bureau of Land Management; Colorado State Office, Denver, CO, 1983.

U.S. Department of Interior. Oil Shale in the Piceance Basin and the Uinta Basin, U.S. Geological Survey, Grand Junction, CO, 1981.

U.S. Environmental Protection Agency. "Environmental Assessment: Perspective on the Emerging 0il Shale Industry," Cincinnati, OH: EPA Industrial Environinental Research Lab, 1981.

Van Baalen, Jack L. "Industrial Siting Legislation: The Wyoming Industrial Development Information and Siting Act -- Advance or Retreat?", Land and Water Law Review, XI(1), 1976, 27-101.

Van Dyke, E. W., and C. Loberg. "Community Studies: Fort McMurray, Anzac, Fort McKay," Calgary: Alberta 0il Sands Environmental Research Program, 1978.

Voss, P. R., and H. C. Krebs. The Use of Federal Revenue Data for Improving Current Estimates of Average Household Size for Minor Civil Divisions: An Evaluation, Technical Series 70-5, Madison: Applied Population Laboratory, Department of Rural Sociology, University of Wisconsin.

Wadsworth, H. A., and J. M. Conrad. "Impact of New Industry on a Rural Community," Lafayette, IN: Indiaṇa Agricultural Experiment Station, Bulletin \#811.

Wallop, Malcolm. "Energy Impact: A Perspective From the Senate on Federal Causes, Cares and Conflicts," in The Boom Town: Problems and Promises in the Energy Vortex, Davenport, Joseph, III, and Judith Nnn Davenport, eds.; Laramie, WY: University of Wyoming, 1980.

Watson, K. S. "Measuring and Mitigating Socio-economic Environmental Impacts of Constructing Fnergy Projects; An Emerging Regulatory Issue," Natural Resource Law, 10, 1977, 393-400.

Weber, Bruce, and Robert Howe11, eds. Coping with Rapid Growth in Rural Communities, Boulder, Cu: Westriew Press, 1982.

Weiland, J. S., F. L. Leistritz, and S. H. Murdock. "Characteristics and Residential Patterns of Energy Related Work Forces in the Northern Great Plains," Western Journal of Agricultural Economics, 4, 1979, 57-68.

Welsz, R. "Slress and Mental Health in a Boomtown," in Boomtowns and Human Services, Davenport, J. A., and J. Davenport, III, eds.; Laramie: University of Wyoming, 1979.

White, Gilbert F. "Environinental Impact Statements," The Professional Geographer, 24, 1972, 302-309. 
Wilke, Arthur S., and Harvey R. Cain. "Social Impact Assessment Under NEPA: The State of the Field," Western Sociological Review, 8 , 1977, 105-108.

Wilkinson, K. P. "Rural Community Development: A Deceptively Controversial Theme in Rural Sociology," The Rural Sociologist, 5(March), 1985, 119-124.

Wilkinsson, K. P., J. G. Thompson, R. R. Reynolds, Jr., and L. M. Ostresh. "Response," Pacific Sociological Review, 25, 1982 , 367-376.

Wilkinson, K. P. "Implementing a National Strategy of Rural Development," The Rural Sociologist, 4 (Sept.), 1984, 348-353.

Wilkinson, K. P. "Social Well-Being and Community," Journal of the Community Development Society, 10(1), 1979, 5-16.

Wilkinson, K. P., D. J. Hobbs, and J. A. Cnristenson. "An Analysis of the National Rural Development Strategy," The Rural Sociologist, 3 (November), 1983, 384-391.

Wilkinson, K. P., R. R. Reynolds, Jr., J. G. Thompson, and L. M.. Ustresh. "Divorce and Recent Net Migration into the 01d West,":; Journal of Marriage and the Family, 45(May), 1983, 250-258.

Wilkinson, K. P., J. G. Thompson, R. R. Reynolds, Jr., and L. M.. Ostresh. "Local Social Disruption and Western Energy Development: A Critical Review," Pacific Sociological Review, 25(Ju1y), 1982, 275-296.

Wolf, Lharles P. "Social Impact Assessment: The State of the Art Updated," Social Impact Assessment, 20, 1977, 3-22.

Yantis, B. L. "The Economic Impact of Industry on Community Services in Seven Municipalities in the Ozarks Region of Arkansas," Ph.0. Thesis, University of Arkansas, Fayetteville, 1972.

Young, F. W., and R. C. Young. Comparative Studies of Community Growth, West Virginia University Book Store, Morgantown. WV: Rural Sociological Society Monograph \#2, 1972.

Zlllman, Donald N., and Sharon Solomon. "The Impact on Communities and Legal Problems of Major Energy Developments in the United States," Western Australia Law Review, 15(1,2), 1983, 61-81.

Zitter, M., and H. S. Shyrock, Jr. "Accuracy of Methods of Preparing Postcensal Population Estimates for State and Local Areas," Demography, 1. 1964, 227-241. 
PHASE 2. RESTRICTIONS ON RESOURCE UTILIZATION 


\section{LAND OMNERSHIP \\ Dy James Dean}

Land ownership refers to the status of land, whether it is privately owned or managed by a government agency. Status indicates the specific agency that manages the land (e.g., BLM, Forest Service) and refers to specific parcels of land, their location, and their relation to each other. Status also denotes the nature of the ownership--surface or sub-surface, total or in part, well-defined or clouded (legally questionable).

\section{Mestern oil Shale Areas}

Before 1920, oil shale was a locatable mineral under the Mining Law of 1872. As for gold or any other valuable material, a claim was staked and filed in the local county courthouse. So long as the claim was legally filed and a minimum amount of development work was done, the claim was real property (had intrinsic value of its own). A claim held for a period of time could eventually "go to patent" (become the legal property of the claim owner). The process by which a claim is evaluated and patented is called adjudication.

Numerous oil snale claims were filed in the western oil shale area, especially during World War 1. Many of these claims are still valid; many are questionable. Currently, these claims are being adjudicated. Due to recent court decisions and policy direction by the BLM, the adjudication and patenting of 82,000 acres of 1 and in the Colorado shale area is proceeding. Disposition of claims on an additional 360,000 acres in Wyoming, Colorado, and Utan is still pending (BLM 1973) (Denver Post 1986). The following tables provide ownership information for the three western oil shale states (BLM 1973). 
Table 12. Federal 0il Shale Lands

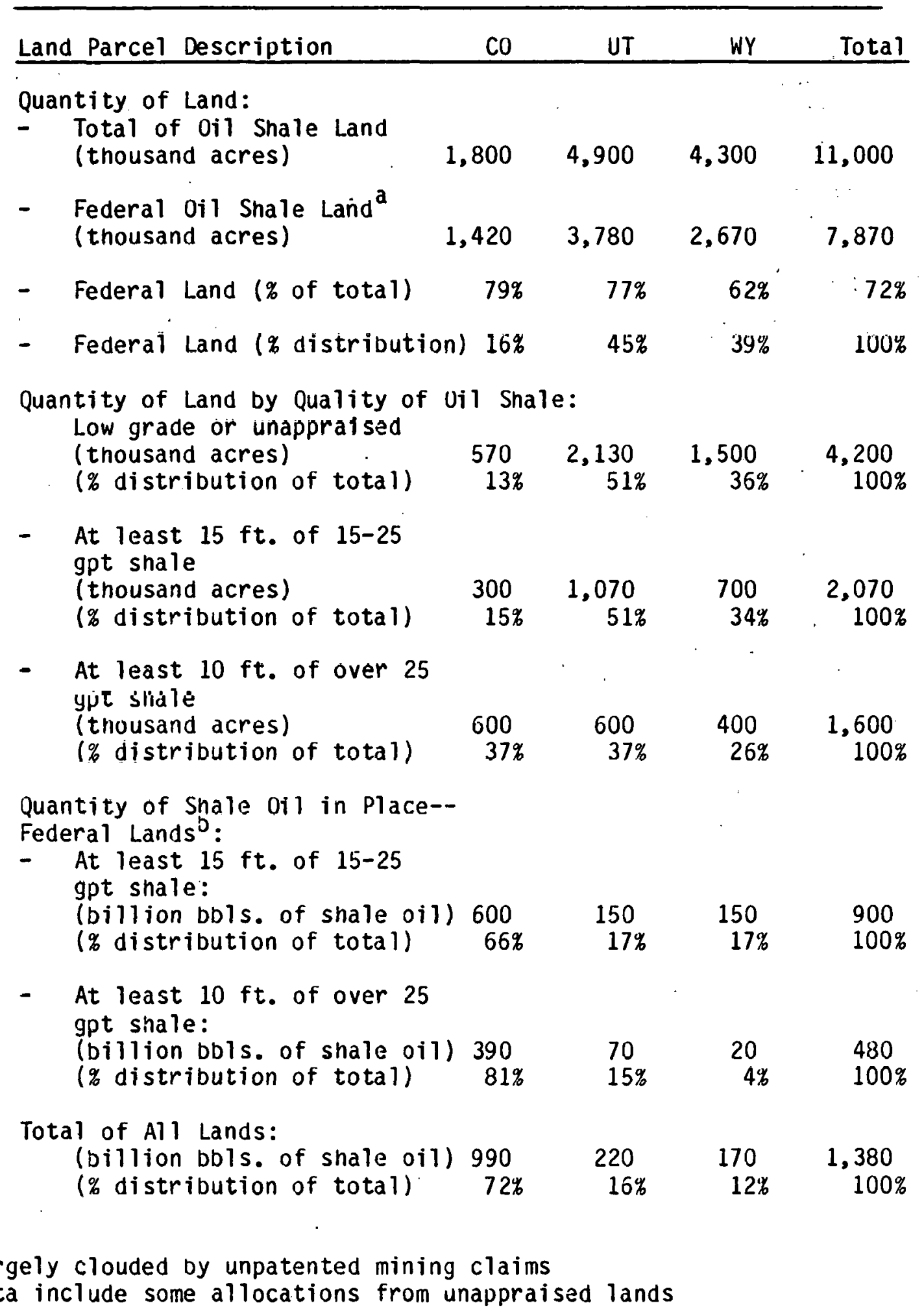


Table 13. Mon-Federal 0il. Shale Lands with Clear Title (Includes Indian and State Lands)

\begin{tabular}{|c|c|c|c|c|}
\hline Land Parcel Description & $\mathrm{CO}$ & UT & WY & Tota1 \\
\hline $\begin{array}{l}\text { Quantity of Land: } \\
\text { - Total 0il Shale Land } \\
\text { (thousand acres) } \\
\text { - Private 0il Shale Lands } \\
\text { (tnousand acres) } \\
\text { - Private Land ( } \% \text { of total) } \\
\text { - Non-Federal Land ( } \% \text { dist.) }\end{array}$ & $\begin{array}{c}1,800 \\
400 \\
21 \% \\
13 \%\end{array}$ & $\begin{array}{r}4,900 \\
1,100 \\
23 \% \\
35 \%\end{array}$ & $\begin{array}{r}4,300 \\
1,600 \\
38 \% \\
52 \%\end{array}$ & $\begin{array}{r}11,000 \\
3,100 \\
28 \% \\
100 \%\end{array}$ \\
\hline $\begin{array}{l}\text { Quality of Private Oil Shale La } \\
\text { - Low Grade or Unappraised } \\
\text { (thousand acres) } \\
\text { (\% distribution) } \\
\text { - At least } 15 \mathrm{ft} \text { of } 15-25 \\
\text { gpt of shale } \\
\text { (thousand acres) } \\
\text { (\% distribution) } \\
\text { At least } 10 \mathrm{ft} \text { of over } 25 \\
\text { gpt shale } \\
\text { (thousand acres) } \\
\text { (\% distribution) }\end{array}$ & $\begin{array}{l}\text { nds: } \\
\qquad \begin{array}{l}165 \\
10 \%\end{array}\end{array}$ & $\begin{array}{l}170 \\
28 \%\end{array}$ & $\begin{array}{c}440 \\
52 \%\end{array}$ & $\begin{array}{l}1,695 \\
100 \%\end{array}$ \\
\hline $\begin{array}{l}\text { Quantity of Shale 0il in Place } \\
\text { Private Lands: } \\
\text { - At least } 15 \mathrm{ft} \text {. of } 15-25 \\
\text { gpt shale: } \\
\text { (billion bbls. shale oil) } \\
\text { (\% distribution) } \\
\text { At least 10 ft. of over } 25 \\
\text { gpt shale: } \\
\text { (billion bbls. shale oil) } \\
\text { (\% distribution) }\end{array}$ & $\begin{array}{l}130 \\
52 \%\end{array}$ & $\begin{array}{l}40 \\
16 \%\end{array}$ & $\begin{array}{l}80 \\
32 \%\end{array}$ & $\begin{array}{l}110 \\
100 \%\end{array}$ \\
\hline $\begin{array}{l}\text { Total of All Lands: } \\
\text { (Dillion bbls. shale oil) } \\
\text { (\% distribution) }\end{array}$ & $\begin{array}{l}210 \\
58 \%\end{array}$ & $\begin{array}{l}60 \\
17 \%\end{array}$ & $\begin{array}{l}90 \\
25 \%\end{array}$ & $\begin{array}{l}360 \\
100 \%\end{array}$ \\
\hline
\end{tabular}


Table 14. Federal oil Shale Lands (Clouded Title)

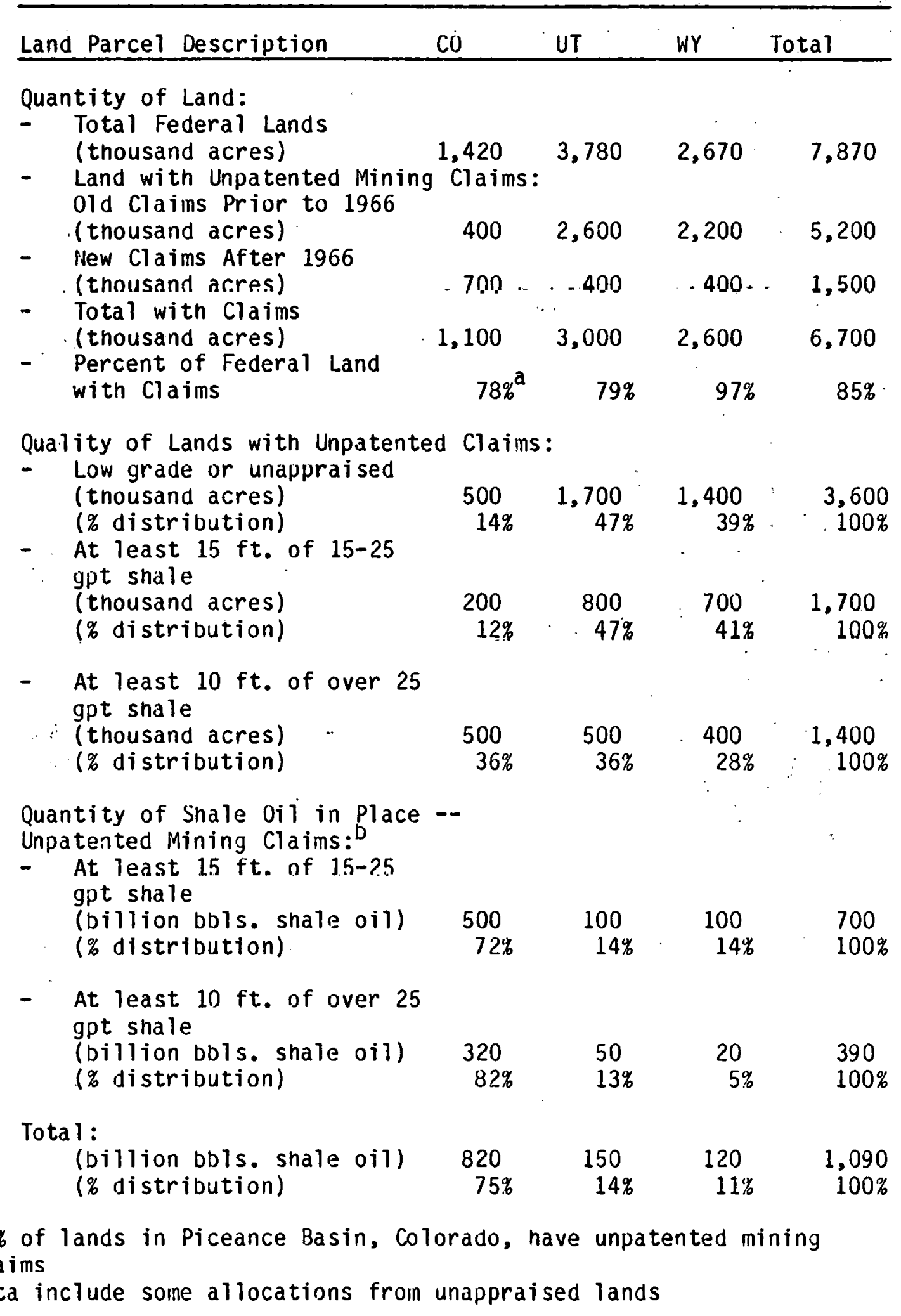


The eastern oil shale area has a much different ownership pattern than the west. The west is sparsely populated, arid, rugged; and remote. The eastern area is densely populated, humid, flat to rolling, and accessible. Eastern lands are primarily in private hands due to early demand for agricultural lands and very early settlement by pioneers. The following table provides ownership information for the eastern shale area:

Table 15. Land Ownership for Eastern oil Shale Area (thousand acres)

\begin{tabular}{lrrr}
\hline State & Private or State & Federal & Total \\
\hline Indiana & 22,656 & 502 & 23,158 \\
Kentucky & 24,188 & 1,324 & 25,515 \\
Unio & 25,853 & 369 & 26,222 \\
Tennessee & 24,831 & 1,897 & 26,728 \\
\hline
\end{tabular}

(Dept. of Commerce 1986)

Federal ownership is primarily in national parks, national forests, and water development lands administered by the Army Corps of Engineers and the Tennessee Valley Authority. Some federal lands are a) so administered by the Department of Defense, the Department of Energy, and the Department of the Interior: 


\section{BIBLIOGRAPHY FOR LAND OWMERSHIP}

Bureau of Land Management. Prototype 0il Shale Leasing Program, Bureau of Land Management, Washington, DC, 1973. .

Department of Commerce. Statistical Abstract of the United States, Wasnington, DC, 1986.

Schmitz, Gary. "BLM Cnief Vows Review of Disputed Mining Clains," The Denver Post, March 4, 1987. 


\section{LAND USE \\ Dy James Dean}

Land use refers (1) to the nistoric and current uses of land units, and (2) to restrictions on land use by laws, regulations, and decisions of individual landowners.

\section{Hestern Oil Shale Areas}

Western oil shale land is predominantly owned by the federal government and managed by two agencies: the Forest Service (FS) in the Department of Agriculture and the Bureau of Land Management (BLM) in the Department of the Interior. Other agencies with jurisdiction or surface management responsibilities include the Department of Energy, the Bureau of Reclamation, the Fish and Wildiife Service, the National Park Service, and the Environmental Protection Agency.

\section{Land Use Planning}

The FS and BLM are required by law to prepare land use plans on all administered lands. The FS prepares National Forest Plans under the authority of the Multiple Use-Sustained Yield Act of 1960, the Forest and Rangeland Renewable Resources Planning Act of 1974, and the National Forest Management Act of 1976 (USFS 1983). The Forest Service planning procedures are defined in 36CFR, Part 219 (CFR, 1986). The BLM's planning procedures are defined in 43CFR, Part 1610, and its authority is defined in the Federal Land Policy and Management Act of 1976 (CFK 1986):

The two processes for land use plans are similar. Botn define the issues, inventory, public participation, and a set of alternatives. Both use a preferred set of alternatives based on an analysis of the range of all alternatives. The differences are in application; the BLM plan is based on the Resource Area, while the Forest Service plans at the National Forest level. In application, the Forest Service plans all activities at once in Ranger Districts, while the BLM plans all applications of an activity at one time (BLM 1983) (USFS 1983).

Land use plans and related documents are "major actions," as defined by the National Environmental Policy Act of 1969 (NEPA). As such, they require an environmental impact statement as defined by the Council on Environmental Quality Regulations, 40CFR, Part 1500 (CFR 1986), which inplements the NEPA.

Land Uses

Land use in Colorado, Utah, and Wyoming is summarized in the following table (BLM 1973). 
Table 16. Land Use and Suitability

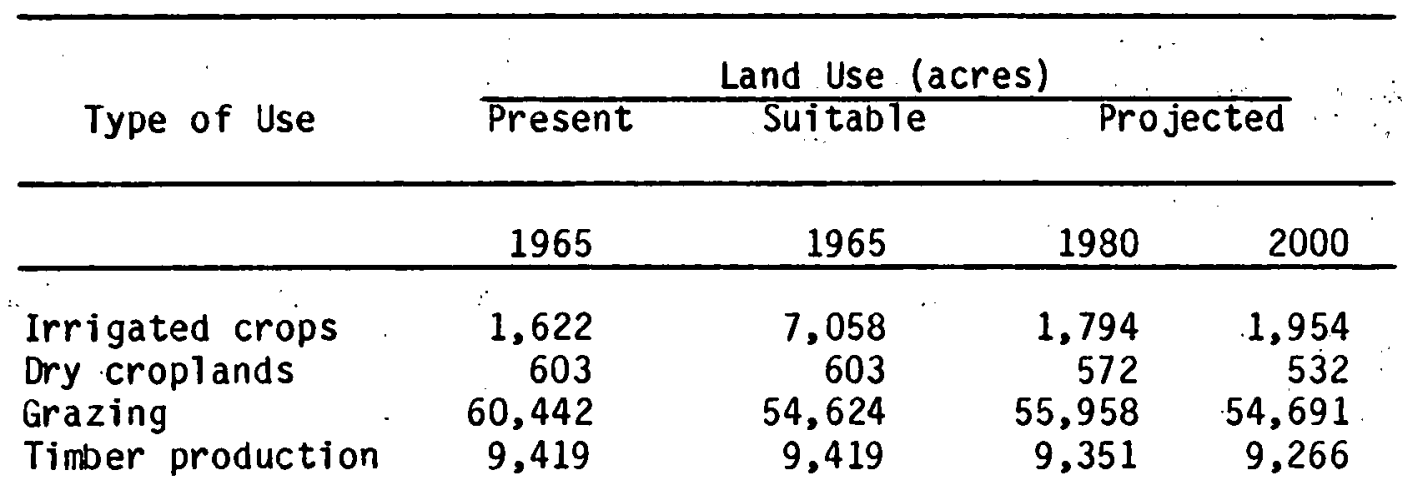

\section{Eastern 0il Shale Areas}

Land Use Planning

Land use plans are primarily a state and community responsibility in the East. Land uses in the eastern shale area are extremely varied. Statistics are valid only for specific areas. 


\section{BIBLIOGRAPHY FOR LAND USE}

Forest Service. Forest Plan and Environmental Impact Statement, Routt National Forest, United States Department of Agriculture, Routt National Forest, Steamboat Springs, C0, 1983.

Bureau of Land Management. Prototype 0il Shale Leasing Program; Washington, DC, 1973.

Tities 43 and 36 (Public Lands, Interior, and Agriculture). Code of Federal Regulations, U.S. Government Printing Office, Washington, DC, 1986.

Bureau of Land Management. Book Cl1ffs Resource Management Plan and EIS, Vernal (Utan) District, 1983. 


\section{WATER USE RESTRICTIONS \\ Dy Gretchen Berdan}

The water use restrictions described here are for industries that withdraw and use water. Wastewater discharge restrictions are discussed later in this section (Phase 2).

\section{Definition of Water Rights}

"Water right" is the legal right to use water. U.S. water rights vary from state to state, but water rights are universally recognized as real property. A water right may be sold, leased, abandoned, or severed from the lands to which it is attached.

In the western U.S., some states hold the water rights for the benefit of their residents. Rights to use water (ground or surface) are neld, acquired, or assigned to and among private parties by statute or pursuant to case law.

Because water rights are considered real property, they are entitled to all the constitutional and statutory protections of real property.

\section{Water Law}

Water law recognizes five distinct classes of water (Tank 1983):

1. surtace water in wazer courses (rivers, creeks, streams, lakes),

2. diffused surface water (water not in watercourses or 1akes).

3. groundwater in "defined underground streams,"

4. percolating groundwater (a 11 other groundwater), and

5. springs (natural discharge points for groundwater).

Three doctrines form the basis of water law in the U.S.: the Riparian doctrine, the Prior Appropriation doctrine, and the California doctrine.

\section{Riparian Doctrine}

Land adjacent to a stream, river, or lake is riparian to that body of water. Under English common 1aw, the waters of the stream are available. on a correlative basis for the use of all riparian owners (American Society of Civil Engineers 1972). In the eastern states, where water has always been considered plentiful, water law generally follows the English common law (riparian). The basic tenets of the riparian water law are (Tank 1983):

1. The water right is incident to ownership of the land. Anyone who owns land physically adjacent to a source of public water owns a right to those waters, and no one else can own the water right. 
2. All those who own land riparian to a single source of water have an equal claim to that water.

3. The water is to be used for "natural purposes," and each user is to return the flow to the channel undiminished in quality and unimpaired in quantity.

Potential oil shale producing states probably following this doctrine are Onio, Tennessee, Alabama, Illinois, Indiana, and Kentucky.

\section{Prior Appropriation (Colorado) Doctrine}

The Appropriation Doctrine is based upon priority of diversion and application of the water to a beneficial use. It is a "first come, first served" approach whereby a limited water supply is put to the most beneficial use. It depends on demonstrating the application of water to a beneficial use rather than on land location as with the Riparian Doctrine.

Western water. law generally follows the Prior Appropriation Doctrine. Applicants for appropriations are placed on a priority list for a particular water source. Appropriative law is usually considered the best system for arid regions where there may not be enough water for all riparian owners.

One form of western water law, the colorado Doctrine, is used in the most arid states with oil shale resources: Colorado, Montana; Utah, and Wyoming. Uther states following this doctrine are Arizona, Idaho, Nevada, and New Mexico. The Colorado Doctrine is essentially the Prior Appropriation doctrine accepted fully by those western states.

\section{California Doctrine}

A second group of states--California, Kansas, South Dakota, Texas, North Dakota, Nebraska, Oklahoma, Oregon, and Wasnington--has both arid and non-arid regions. These states have devised unique systems for superimposing prior appropriation water law upon riparian water law (Tank 1983) which are usually referred to as the California Doctrine.

\section{Surface Hater Rights}

Availability of surface water is influenced in part by the
balance between average precipitation and potential evapotranspiration. Humid regions, where average precipitation exceeds potential evapotranspiration, have a water abundance. The thirty-one eastern states are classified as numid; the six plains states are in the subhumid to semiarid category, where average precipitation and potential evapotranspiration are nearly equal; and the eleven western states are classified as semiarid or arid, where water is generally not available for permanent overland flow to streams or lakes (Tank 1983). 
If water can be made to flow under its own power or can be pumped to an area, then development will be less costly. However, sometimes the costs of developing surface water can involve a large initial capital investment.

\section{Groundwater Rights}

In the eastern states, groundwater is riparian for the landowner because the land overlies the groundwater. The owner of the overlying land either possesses rights analogous to riparian rights on a stream or asserts absolute titie to water under his land. Recent court decisions, however, have made it possible to restrict dormant rights of this nature (ASCE 1972).

Prior appropriation also applies to groundwater in the western states. This is a "first come, first served" approach for which the groundwater must be put to a beneficial use. Groundwater rights are obtained from the controlling state agency (e.g., office of the Wyoming State Engineer).

More restrictions are placed on the development of groundwater because of the potential impacts of overdevelopment. However, groundwater may be less expensive to develop in some cases, as a large initial capital investment is rarely required.

\section{Federal Control of Water Rights}

Water use and development, from initial planning to ultimate water use, are affected by numerous federal regulations (Tank 1983). The Water Resources Council is the principal coordinating body. The federal governinent exercises control primarily over surface waters deemed navigable and used for interstate commerce. The U.S. al so owns reserved water rights, which are used when federal land is renoved from the public domain and reserved for some specific purpose.

The federal government is also frequently involved with Indian and Eskino water rights. Reservations that have been created by treaty, federai statutes, or executive federal orders are reserved as Indian water rights and incorporated as property. include:

Federal agencies and departments with water responsibility

1. Army Corp of Engineers: primarily responsible for federal power development, especially electric power used in interstate commerce and flood control.

2. Department of the Interior:

Bureau of Indian Affairs--administers Indian lands and programs dealing witin irrigation, water supply, and power.

Fish and Wildlife Service--primarily responsible for protecting fish and wildlife in the event of dam and reservoir construction. 
3. Department of Agriculture: provides watershed protection measures to aid flood control; responsibilities are divided between the Forest Service and the Soil Conservation Service; Department of Agriculture also has responsibility for structures and facilities supplying domestic stock and irrigation water.

4. Federal Power Commission: concerned primarily with the development of water power facilities.

\section{State Control of Mater Rights}

Under the Colorado Doctrine, the transfer of sovereignty to the states also transferred full power to control the water. To a large degree, the states exercise jurisdiction over non-navigable water and waters navigable only in intrastate commerce. Most states exercise statutory or administrative (regulative) control over in-stream water uses such as fishing, recreation, scenic areas, and environmental values. Some states have enacted Wild and Scenic River legislation, minimum flow requirements, and permitting systems for excavating, dredging, or filling lakes and streams. State systems for acquisition of water rights are generally based on one of the three doctrines: riparian, prior appropriation, or California.

Water rights are regulated and administered on a rather comprehensive basis in most western states, and eastern states are beginning to increase public water regulations; nowever, the threefold approach (appropriation, adjudication, and distribution) used in the West has not been adopted by eastern states. An increase in protecting the environment and water quality has become apparent in both eastern and western states.

In most western states, including Colorado, Utah, and Wyoming, the chief water administrator is the State Engineer. In other states, the supervising agency is a departinent, board, or commission (Clark 1967).

\section{Hater Rights for an 0il Shale Industry}

Conflicts with Surrounding Users

It is inevitable, especially in the western states where water is not plentiful, that conflicts will arise between the oil shale industry and others such as domestic users, municipalities, agricultural users, and other industries.

Prior to any action pertaining to water rights, a complete inventory of all existing water rights in an area, including both surface and groundwater rights, must be obtained. Complete, up-to date records of appropriation of water rights are generally kept in a central state office, rather than in several county offices, or not recorded at all. 
This simplifies the task of compiling an inventory of existing water rights in and adjacent to an oil shale lease. An inventory of existing water rights will help to avoid conflict and may possibly help to acquire water rights through purchase or severance.

The refinement and nuances of water law in those states witn complex nistories of water litigation are almost limitless (ASCE 1972). Managers in the oil shale industry should be aware that adversary litigation in the field of water law has proved to be very costly, protracted, and unproductive. Therefore, it is essential that managers obtain an inventory of (and an accommodation to) all existing surface and groundwater rights in and adjacent to the oil shale lease.

Example--Acquiring a Water Right in Wyoming

In Wyoming, a water right is applied for using a permit system regulated by the office of the Wyoming State Engineer. The party or company interested in obtaining the groundwater right(s) files an application for a Permit to Appropriate Groundwater. The application requests information about the location of the water right applied for, well information, proposed use of the water, proposed quantity of water to be developed, and other pertinent water use information. A filing fee of $\$ 10$ is submitted for domestic and/or stock watering purposes, and a fee of $\$ 25$ is submitted for irrigation, municipal, industrial, and miscellaneous purposes. Wells to be used for groundwater monitoring require no fee. The application is then examined by the State Engineer's uffice, and the permit is either granted or refused. If the applicant is granted the permit, he must file a form entitled Proof of Appropriation of Water and supply the State Engineer's Office with completion details of the wel1(s).

\section{Further Research Needs}

1. For states with a potential oil shale resource, an analysis of state requirements for obtaining water rights is necessary.

2. Public hearing requirements related to water use for each potential oil shale-producing state need to be ascertained.

3. Availability of surface and groundwater near oil shale leases for each potential oil shale-producing state needs to be determined.

4. Specific potential conflicts with other users need to be identified.

5. Methods for avoiding litigation in each state need to be expressly identified and clarified.

6. Ways to deal with possible litigation over water rights need to be studied in the event such litigation is brought against an oil shale industry. 


\section{BIBLIOGRAPHY FOR HATER USE RESTRICTIONS}

American Society of Civil Engineers. "Ground Water Management," Update for Manual No. 40, 1972.

American Society of Civil Engineers. "Groundwater Basin Management," Committee on Groundwater of the Irrigation and Drainage Division of the ASCE, New York, (no year).

Anderson, T. L. Water Rights; Scarce Resource Allocation, Bureaucracy, and the Environment, Ballinger Publishing Co., Cambridge, MA, 1983.

Angell, J. K. A Treatise on the Common Law in Relation to Water Courses, Boston: Milliard, Gray and Co., 1833.

Arizona Water Cominission. "Annual Report 1970-1971," Pheonix, AZ, 1971.

Baker, D. M. Water Supply and Utilization: an Outline of Hydrology from the viewpoint of the Arid Section of the U.S. Together with an Outline of Water Law and Its Administration as it was Developed in the Arid States, NY: J. Wiley and Sons, 1930.

Bishop, F. A. "Report to the Wyoming Association of Municipalities on Instream Flow Legislation and Municipal Water Rights," Banner and Associates, Inc., Cheyenne, WY, 1982.

Bockrath, J. T. Environmental Law for Engineers, Scientists, and Managers, NY: McGraw-HiTT, 1977.

Clark, R. E. "Waters and Water Rights--Eastern, Western, Federal," Vol. 1, Indianapolis, IN: The Allen Smith Co., 1984.

DuMars, C. T., M. O'leary, and A. E. Utton. "Pueblo Indian Water Rights, a Struggle for a Precious Resource," Tucson: University of Arizona Press, 1984.

Dunbar, R. G. "Forging New Rights in Western Waters," Lincoln: University of Nebraska Press, 1983.

Foreman, R. L. "Indian Water Rights: A Public Policy and Administrative Mess," Danville, IL: Interstate Printers and Publishers, 1981.

Haller, T. G. "California-Nevada Interstate Water Compact: A Study on Controversy," Ph.D. dissertation, University of Nevada, Reno, 1981.

Hendrickson, G. 0. Water Rights on the North Platte River: A Case Study of the Resolution of an Interstate Water Conflict, Ph.D. dissertation, University of Wyoming, Laramie, 1975. 
Hirshleifer, J. Water Supply, Economics, Technology and Policy, Chicago: University of Chicago Press, 1960.

Hundley, N. Dividing the Waters: A Century of Controversy Between the United States and Mexico, Berkeley: University of California Press, 1966.

Hunter, L. C. A History of Industrial Power in the United States, 1780-1930, University of Virginia Press, Charlottesville, VA, 1979.

Hutchins, W. A. "Selected Problems in the Law of Water Rights in the West," USDA Misc. Pub1. No. 418, 1942.

Jacobstein, J. M. Water Law Bibliography, 1847-1965; Source Book on U.S. Water and Irrigation Studies: Legal, Economic, and Political, Silver Springs, MD: Jefferson Law Book Co., 1966.

Jamail, M. H., J. R. McCain, and S. J. Ullery. Federal-State Water Use Relations in the American West: An EvoTutionary Guide to Future Equilibrium, Tucson, AZ: University of Arizona, Office of Arid Land Studies, 1978.

Maass, A. ....and the Desert Shall Rejoice: Conflict, Growth and Justice in Arid Environments, MIT Press, Cambridge, MA, 1978.

Morrison, R. S. Mining Rights on the Public Domain, Lode and Placer Claims, Tunnels, Mill Sites and Water Rights, Denver, Cu: The Smith-Brooks Printing Co., 1905.

Newel, F. H. Principles of Irrigation Engineering, Arid Lands, Water Supply, Storage Works, Dams, Canals, Water Rights and Products, New York: McGraw-Hi17 Book Co., 1913.

Radosevich, G. E. Evolution and Administration of Colorado Water Law, 1876-1976, Fort Collins, CU: Water Resources Publication, 1976.

Rechard, P. A. Compacts; Treatics and Court Decrces; Documents on the Use and control of Wyoming's Interstate Streams, State of Wyoming, Cheyenne, 1971 .

Tank, R. W. Legal Aspects of Geology, New York: Plenum Press, 1983.

Teclaff, L. A. Abstraction and Use of Water; A Comparison of Legal Regimes, New York: 1972.

Travis, C. C., and E. L. Elnier. "Groundwater Pollution: Environmental and Legal Problems," presented at the 1984 AAAS National Meeting, New York, May 25-30, 1984.

Trelease, F. J. "Severance of Water Rights from Wyoming Lands: A Report to the Wyoming Legislative Research Committee," Cneyenne, WY, 1960. 
University of Wisconsin. Oil Shale Development in Northwest Colorado; Water and Related Land Impacts, Water Resources Management Workshop, Madison, WI, 1975.

Waite, G. G. "A Four-State Comparative Analysis of Public Rignts in Water," University Extension, Madison Dept. of Law, University of Wisconsin, 1967

Water Resources Research Institute. Publications of the Wyoming Water Resources Research Institute: water Resources Series and Miscellaneous Publications, Theses, Land and Water Law Review, Sitver Springs, MD: Jefferson Law Book Co., 1966.

Waterfield, L. W. Conflict and Crisis in Rural America, New York: Praeger, 1985.

Weatherford, G. D., and F. L. Brown. New Courses for the Colorado River: Major Issues for the Next Century, AlDuquerque: University of New Mexico Press, 1986.

Wyoming State Engineer, "Regulations and Instructions," State Engineer's Office, Cheyenne, WY, 1974. 


\section{RESTRICTIONS ON EMISSION TO AIR \\ by John Mordin}

The Clean Air Act of 1977 requires that national air quality standards be established and that each state enforce the air quality standards. A distinction is made between primary air quality standards and secondary air quality standards. Primary standard refers to levels of air quality necessary with an adequate margin of safety to protect public health. Secondary standard refers to levels of air quality necessary to protect public welfare from known adverse effects of a pollutant.

The Clean Air Act also requires that the administrator (EPA) publish national emission standards for hazardous air pollutants and makes distinctions between moving pollutant sources (venicles) and stationary pollutant sources. Stationary pollutant sources are further subdivided into new sources and old or existing sources. The Clean Air Act also establishes air quality control regions for different sections of the country.

At this time (1987), the EPA nas published regulations for the following hazardous air pollutants: asbestos, berylium, mercury, and vinyl chloride, berylium rocket motor firing, Radon-222 from underground uranium mines, radionuclide emissions from DOE facilities, leaks of volatile hazardous air pollutants (e.g., benzene) from equipment, and arsenic emissions from certain manufacturing operations. This list may be expanded in the future to include neavy metal emissions (e.g., cadmium, nicke1) and other emissions considered hazardous. At this time, hazardous air pollutant regulations do not apply to oil shale retorting operations even though traces of mercury, arsenic, selenium, cadmium, lead, and nickel are sumetines detectaole in the off gas. These elements, especially mercury and arsenic, are of concern and may be regulated in the future.

Emissions from retorting operations do affect the air quality. Air quality standards are concerned with concentrations of particulates, sulfur dioxide, nitric oxide or NO, lead, carbon dioxide, and ozone in the atmosphere at a particular location (Table 14). States are required to regulate the amount of particulates, sulfur species, nitrogen species, carbon dioxide, and volatile organic carbon from emission sources so that air quality standards are maintained. Emissions regulated in off gases from retorting operations are typically sulfur species (sulfur dioxide and hydrogen sulfide), particulates, carbon dioxide, and nydrocarbons (products of incomplete combustion). $\mathrm{NO}$ is regulated but concentrations are usualiy low in the off gases. Particulates from fugitive dust einissions are regulated. If fuel or gasoline is stored on site or if extensive painting or other coating operations are done, the limits on volatile organic carbon enissions may apply.

Some areas in the U.S. do not meet air quality standards and are classified as "nonattainment." Permitting requirements for emissions are much more stringent for these locations. Locations of areas which 
do not meet primary and/or secondary air quality standards are published in the Code of Federal Regulations, 40 CFR part 81 . This list is continuously updated.

The oil shale developer must obtain the required air permits from the state. The emission limits specified on the permit will depend upon the location of the plant and whether air quality does or does not meet national standards (Table 17).

Section III of the Clean Air Act requires that the U.S. Environmental Protection Agency (EPA) promulgate standards of perforinance for air emissions from new stationary sources. Stationary sources include all oil shale operations except vehicles. Standards of performance for new sources (those constructed after promulgation of regulations) are more stringent than for existing sources. The state administers the permitting programs upon submission to the EPA of a satisfactory program for implementation, maintenance, and enforcement of an air quality standards plan within that state.

Some states (Colorado, Kentucky) have published air quality regulations specific to oil snale operations (e.g., Amended colorado New Source Performance Standard for $\mathrm{SO}_{2}$ einissions from oil shale production facilities). Uther states apply standards from the mining. industry or petroleum industry.

If the air quality at the location is cleaner than national standards, the oil shale developer must obtain a "Prevention of Significant Deterioration of Air Quality Permit" for any new or modified facility, including pilot plants. If the air quality at the location is less than national standards, the developer must obtain a "Construction Permit for Non-Attainment Area." To obtain that permit, the developer must show that the proposed emissions source will obtain the "lowest achievable emission rate" of any pollutant. Also, the intended source inust indicate that significant offsets are available from other sources in the area so that air pollution is not increased on an overall basis. Also, all developers, whether in attainment or non-attainment areas, must obtain a "Notification of Construction" permit for any new source.

For those locations where the air quality is cleaner than national standards, the maximum increnental increase of particulate and sulfur dioxide which is allowed is dependent upon whether the shale oil facility is located in a class I, II, or III area. The maximum allowable increase is most stringent for a Class I area and least stringent for a class III area. For example, the maximum allowable increase (annual arithmetic mean) in sulfur dioxide over baseline concentrations (no oil shale developinent) is $5 \mathrm{\mu g} / \mathrm{m}^{3}$ for a Class I area, $20 \mu \mathrm{g} / \mathrm{m}^{3}$ for a Class II area, and $40 \mu \mathrm{g} / \mathrm{m}^{3}$ for a Class III area. Also, National Air Quality Standards (Table 17) cannot be exceeded. One year of ambient air quality data must be taken at the location of the proposed shale oil plant in order to establish baseline conditions. By federal mandate, international parks, national wilderness and national memorial parks in excess of 5,000 acres in size, and national parks in excess of 6,000 acres must be 
designated as Class I areas. A state has the option of designating other geographic locations as Class I, II, or III areas subject to constraints listed in the Clean Air Act. These rules apply to obtaining a "Prevention of Significant Deterioration of Air Quality" permit.

Table 17. Environmental Protection Agency Regulations on National Primary and Secondary Ambient Air Quality Standards (units are $\mu \mathrm{g} / \mathrm{m}^{3}$ )

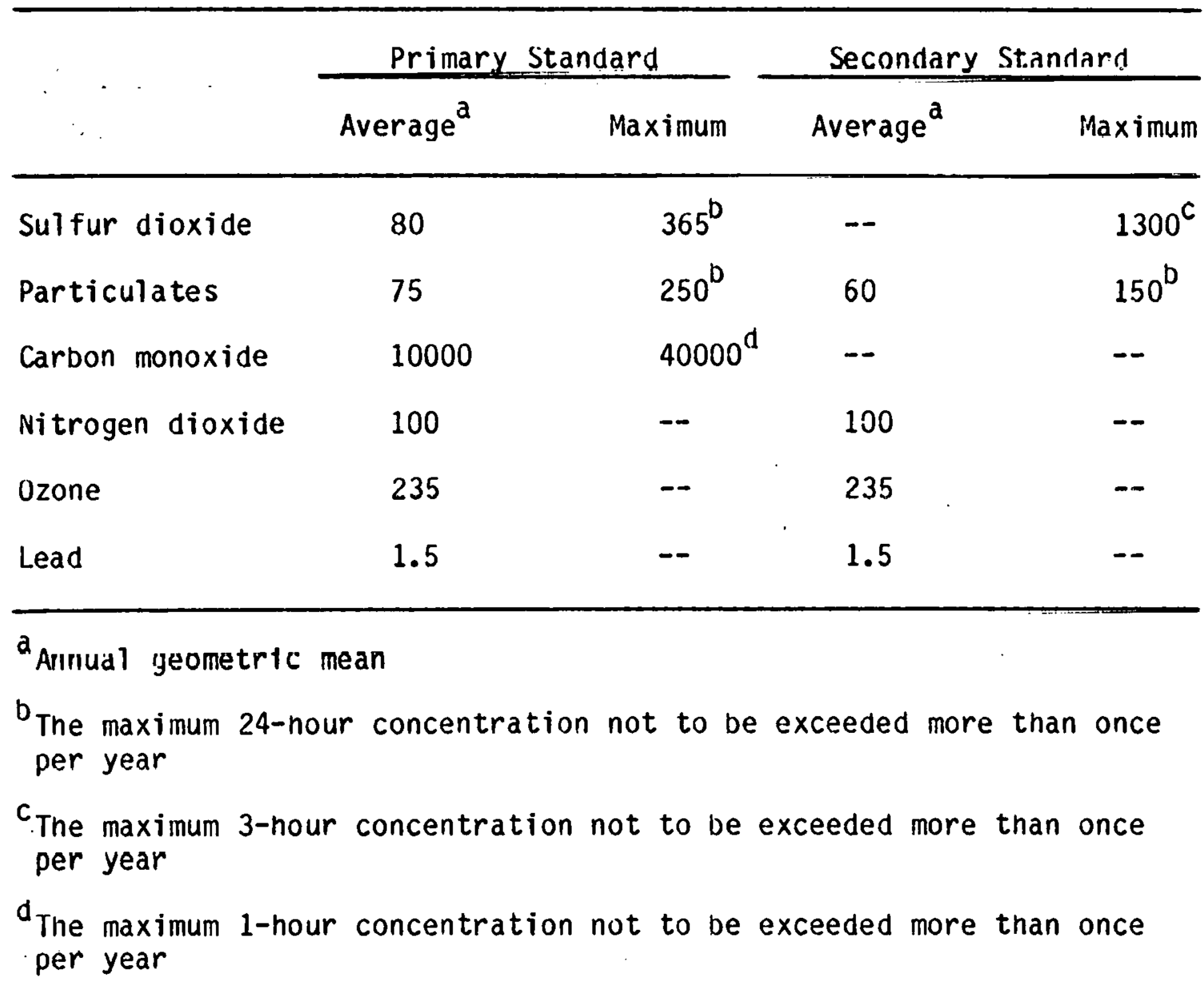




\section{RESTRICTIONS ON HASTEHATER DISCHARGES by John Mordin}

\section{Ceneral}

Wastewater discharges to. surface waters are regulated by the Clean water Act. Wastewaters disposed by well injection are regulated by the Federal Safe Drinking Water Act. Certain waste solids and liquids are considered hazardous and are regulated by the Resource and Recovery Act of 1976 (amended 1984); these regulations are also designed to prevent toxic or hazardous chemicals from contaminating surface water and groundwater. If a dike, dam, or other construction will be built in navigable waters, permits from the Army corps of Engineers must be obtained. If water is to be impounded or diverted, the U.S. Fish and Wildlife Service must be notified. Regulations authorized by the Historic Sites Act of 1935 also apply if a dam is constructed.

Clean Water Act (Surface Wastewater Disposal Including Monpoint Sources)

The goal of the Clean Water Act (1977) was to eliminate pollutants in navigable waters by 1985. Obviously, this goal has not been completely met. Navigable waters refers to any surface water within the U.S. and contiguous zone, even surface waters not used for navigation. In February 1987, Congress reauthorized the Clean water Act. Section 319 of the revision requires each state to prepare an assessment report and management prograin for nonpoint source pollution.

A number of perimits authorized by the Clean Water Act apply to oil shale plants and are administered by the states. The shale oil facility must obtain a National Pollutant Discharge Elimination System (NPDES) permit for each discharge into navigable waterways. It must also have on file an approved "Spill Prevention control and Countermeasure Plan" which applies to chemicals stored on site which could potentially spill and contaminate surface waters. Approval is granted by the EPA and by state agencies. Local governments may also have a version of the "Spill Prevention Control and Countermeasure Plan" or other permits for storage of hazardous materials. If a spill does occur, the EPA, U.S. Coast Guard (if applicable), state agencies, and local agencies must be notified even if the spill is confined to the property. Spills include oil.

The Clean Water Act. alsn forbids the discharge of toxic pollutants into navigable waters. Toxic pollutants include aldrin/dieldrin, DOT, endrin, toxophene, benzidine, and polychlorinated biphenyls.

The state agency sets maximum allowable pollutants for each discharge on the facility NPDES permits. Several factors are considered when setting pollutant limitations: (1) effluent guidelines promulgated by the EPA for various industries; (2) the requirement under the clean water Act to maintain in-stream water 
quality standards; and (3) state water quality standards which vary according to the location and the water's intended use and are subject to EPA approval.

Pollutant limitations likely to be specified on oil shale facility NPDES permits include $\mathrm{pH}$, suspended solids, total dissolved solids (or some other measure of salinity), phenols, total organic carbon, biological oxygen demand, temperature, and heavy metals. The permit may al so require measurement of some organic compounds.

The Clean water Act specifies that the flow-weighted average annual salinity in the lower main stem of the Colorado River system be maintained at or below the average value for 1972 (section 120.5(D) of 40 Code Federal Regulations). Colorado, Utan, Wyoming, and other states are required to obtain from the EPA approval for water salinity and to submit a plan for compliance with standards. Therefore, the state agencies for Colorado, Utah, and Wyoming can be expected to regulate salinity of any discharges from shale oil plants.

Some eastern states are concerned about drinking water contaminated with brines from stripper oil wells. If oil shale is developed in the East, eastern states will probably include salinity or total dissolved solids as part of their list of regulated pollutants. Constituents such as phenols in wastewater which react with chlorine (as in the drinking water supply for a downstream community) to form chlorinated organics will almost certainly be regulated under the NPDES permit.

The EPA regulates discharges from publicly owned treatment works (PUTW) and the introduction of industrial wastes to the POTW. Basically, shale oil plants cannot discharge wastewater to a PUTW that would result in the PUTW violating its NPDES permit. Toxic pollutants which are sometimes detectable in ofl shale retort waters include antimony, arsenic, benzene, cadmi um, copper, cyanide, lead, mercury, naphthalene, nickel, nitrophenols, phenol, phthalate esters, polynuclear aromatic hydrocarions, selenium, toluene, and zinc. Any of these chemicals may be regulated if the oil shale plant discharges to a PUTW, as well as suspended solids, salinity, $\mathrm{pH}$, temperature, oil, and grease.

Section 319 of the Clean Water Act (February 1987) requires that each state prepare an assessment report (due August 1988) and a inanagement program for nonpoint source pollution. The major nonpoint source pollution from shale oil plants is leachate from retorted shale. Retorted shale is usually moisturized (15\% optimum) with produced water or other contaminated water. States can be expected to regulate this leachate and other surface runoff as required by the Clean Water Act (1987).

\section{Safe Orinking Hater Act (Injection Hells)}

The Safe Drinking water Act requires that the EPA establish requirements for underground injection of wastewater (or other liquids) (40 CFR 144). The EPA also regulates minimum standards for 
state underground injection control requirements (40 CFR 145). Special rules apply if the injection well is in an area with a sole source aquifer which, if contaminated, would create a significant hazard to public nealth (40 CFR 149). If the shale oil plant plans to dispose of wastewater by underground injection, a well operation permit must provide evidence that there will be no movement of fluid containing any contaminant into underground sources of drinking water before the permit can be granted. The burden of proof is on the operator. Generally, this means that the well Dore must be a designated distance from the nearest underground source of drinking water and that the well casing will prevent the movement of fluids into or between underground sources of drinking water. An aquifer which contains less than 10,000 milligrams per liter (mg/L) of dissolved solids is classified as an underground source of drinking water even if it is not currently being used for numan consumption unless the aquifer is specifically exempted.

Underground injection control permit rules identify five types of injection wells with different criteria for each type. Class I injection wells inject wastewater, including hazardous waste, beneath the lowermost formation containing an underground source of drinking water witnin one quarter mile of well bore. Class II wells are used to enhance oil or natural gas production. Class III wells inject fluids for the extraction of minerals. Class IV wells inject radioactive or hazardous waste above a formation which is within one quarter mile of an underground drinking water aquifer. Class $V$ wells are used for several categories not covered by classes I through IV.

Examples of Class $V$ wells applicable to oil shale development include (1) injection wells for in situ recovery of oil shale, (2) cooling water return flow injector wells, and (3) injection wells used for experimental technologies. 


\section{STATE AGENCY CONTACTS FOR REgULATIONS AMD PERHITS}

\section{COLORADO}

Colorado Department of Health

Waste Management Division

4210 East 11th Ave.

Denver, C0 80220

Colorado Air Pollution

Control Division

4210 tast 11 th Ave.

Denver, Co 80220

Solid Wastes (303) 331-4806 Wynn Eakins

Water Quality Control, Permits and Enforcement

Air Pollution Control (303) 331-8500

Mining. and Land Reclamation (303) 866-3401

(303) $331-4590$

\section{HYOMIMG}

Department of Environmental Quality

122 West 25th St.

Cneyenne, WY 82002

Solid Wastes (307) 777-7752

Department of Water Quality (307) 777-7781

Department of Air Quality (307) 777-7391

UTAH

Division of Environmental Health

Bureau of Solid and Hazardous Waste Management

P.U. Box $16 \% 00$

Salt Lake City, UT 84116-0700

Bureau of Water Pollution Control

P.0. Box 16700

Salt Lake City, UT 84116-0770

(801) 538-6146

Bureau of Air Quality

P.0. Box 16690

Salt Lake City, UT 84116-0690

(801) 538-6108 


\section{KENTUCKY}

Attn: Ms. Valerie Wickstrom

Permits Coordinator

Office of the Secretary

Natural Resources and Environmental Protection Cabinet

Fifth Floor, Capital Plaza Tower

Frankfurt, KY 40601

(502) $564-3350$

\section{INDIAKA}

Copies of Regulations:

Legislative Services Agency

Administrative Code and Register Division

302 State House

Indianapolis, IN 46225

(317) 232-9557 Attn: Linda Miller

Al so: Office of Technical Assistance (317) 232-8154

Indiana Air Pollution Control Board

1330 West Michigan Street

Indianapolis, IN 46206

OHIO

Onio EPA

360 East Rroad St.

Columbus, $\mathrm{OH} 43266$

Copy of Regulations (614) 481-2115 Attn: Mary Kavin

Air Pollution (614) 481-4310

Hazardous Waste (6́14) 481-7200

Water (614) 481-7025 


\section{SOLID WASTE \\ by Robert Donovan}

The Resource Conservation and Recovery Act (RCRA) (1976) defines solid waste as:

Any garbage, refuse, or sludge from a waste treatment plant, water supply treatment plant, or air pollution control facility and other discarded material, including solid, liquid, semi-solid, or contained gaseous material resulting from industrial, commercial, mining and agricultural operations, and from community activities. [RCRA 1004(27)]

Ihis detinition was expanded by the Environmental Protection Agency (EPA) (40 CFR 261.2) which defined a solid waste as "any discarded material" with the exclusion of (1) domestic sewage, (2) mixtures of domestic sewage that pass through a publically owned sewer system "to a publically-owned treatment works for treatment," (3) point source industrial wastewater discharges subject to regulation under the clean Water Act, (4) irrigation return flows, (5) radioactive materials governed by the Atomic Energy Act, (6) materials which remain after in situ mining which are not removed from the ground, (7) pulping liquors, and (8) "spent sulfuric acid used to produce virgin sulfuric acid" (40 CFR 261.4). Additionally, variances from classification as a solid waste can be granted by the Regional EPA Administrator on a case by case basis for certain recyclable materials (40 CFR 260.30-31).

\section{Solid Wastes Associated with the oil Shale Industry}

Full-scale oil shale processing facilities are expected to generate an array of mining and petroleum refinery wastes. An inventory of all solid wastes associated with the oil shale industry is difficult to compile. The amount and types of waste vary greatly depending on the type of retorting process (true in situ, modified in situ, or surface retorting; direct or indirect heating) and the extent of shale oil upgrading that occurs on-site. Solid wastes associated with shale oil plants are discussed in the Phase 3 section.

\section{Federal and State Solid Waste Regulatory Provisions}

Federal provisions regarding the disposal of solid wastes on land do not apply to mining, agricultural, and hazardous wastes $(40$ CFR 241.1). Thus, solid wastes associated with the synfuels industry are exempt from solid waste disposal regulations.

However, non-unique wastes (e.g., refinery by-products, garbage, scrap) are subject to all federal land disposal and handiing regulations for wastes processed and disposed of on federal property. These regulations are in Chapter 40 of the code of Federal Regulations in the following sections: 
40 CFR 241 Guidelines for the land disposal of solid wastes

40 CFR 243 Guidelines for the storage and collection of residential, commercial, and industrial solid waste

40 CFR 255 Identification of regions and agencies for solid waste management

40 CFR 257 Criteria for classification of solid waste disposal facilities and practices

State and local minimal guidelines for solid waste disposal are mandated by the Solid Waste Disposal Act (amended by the Resource Conservation and Recovery Act of 1976) in 40 CFR 256. In addition, states may further regulate the handling of solid wastes above these minimal federal guidelines. A list of solid waste state regulations and administrative agencies for Colorado, Indiana, Kentucky, Onio, Utan, and Wyoming follows:

\section{COLORADO}

State Agency to Contact

For processed oil shale disposal contact:

Department of Natural Resources

Mined Land Reclamation Board

For other solid. wastes contact:

Department of Health

Uffice of Health and Environmental Protection

4210 East 11th Avenue

Denver, CO $80220 \quad$ (303) 320-8333

Applicable State Laws or Statutes

Colorado Solid Waste Disposal Sites and Facilities Law. Title 30, Article 20, Part 1: Solid Waste Disposal Sites and Facilities

Resulting State Regulations or Rules

Colorado Waste Facility Siting Rules

Code of Colorado Regulations

Title 5, Department of Health

Chapter 1007, Article 2 - Solid Waste Disposal

Sites and Facilities 


\section{INDIANA}

State Agency to Contact

Solid Waste Management Board P.0. Box 1964

1330 Michigan Street

Indianapolis, IN 46202

(317) $633-0170$

Applicable State Laws or Statutes

Indiana Refuse Disposal Act

Title 32, Cnapter 9, Article 30

Solid Waste Disposal

Resulting State Regulations or Rules

Indiana Solid Waste Facility Site Approval

Indiana Adininistrative Code, Title 323

Article 1

\section{KENTUCKY}

State Agency to Contact

Departinent of Natural Resources and

[nvironmental Protection

Division of Waste Management

1121 Louisville Road, Pinehil1'Plaza

Frankfort, KY 40601 (502) 564-6716

Applicable State Laws or Statutes

Kentucky Garbage and Refuse Disposal Law

Kentucky Revised Statutes

Title IX, Chapter 109 - Solid Waste Management

Resulting State Regulations or Rules

Kentucky Administrative Regulations Title 104

Department of Environmental Protection

Cnapters $30-47$

OHIO

State Agency to Contact

Environmental Protection Agency

Office of Land Pollution Control

P.0. Box 1049

361 East Broad Street

Columbus, $\mathrm{OH} \quad 43216 \quad$ (614) $466-7220$ 
Applicable State Laws or Statutes

Onio Solid and Hazardous Waste Disposal Law Title 37, Health and Safety

Chapter 34, Solid and Hazardous Waste Laws

Resulting State Regulations or Rules

Onio Solid Waste Disposal Regulations

Onio Administrative Title 3745

Chapter 27, Solid Waste Disposal Regulations

UTAH

State Agency to Contact

Department of Health

Division of Environmental Health

Bureau of Solid Waste Management

150 West North Temple Street

P.0. Box 2500

Salt Lake City, UT 84110

(801) $533-4145$

Applicable State Laws or Statutes

Utah Solid Waste Management Act

Utah Code - Annotated

Title 26 - Healtn Chapter 32

Utah Solid and Hazardous Waste Act

Utan Code - Annotated

Title 26 - Health Chapter 14

Resulting State Regulations or Rules

Utan Solid Waste Disposal Regulations

Utan State Board of Health Code of Solid

Waste Disposal Regulations

Adopted July 17, 1974

HYOMING

State Agency to Contact

Department of Environmental Quality

Solid Waste Management Program

401 West 19th Street

Cheyenne, WY 82002

(307) $777-7753$ 
Applicable State Laws or Statutes

Wyoming Environmental Quality Act

Wyoming Statutes

Title 35 - Public Health and Safety

Chapter 11 - Wyoming Environmental Quality Act

Resulting State Regulations or Rules

RuTes and Regulations of the Wyoming Department

of Environmental quality, Solid Waste Management

Program - Chapter 1 


\title{
HAZARDOUS HASTE \\ by Robert Donovan
}

\begin{abstract}
The Resource Conservation and Recovery Act (1976) defines hazardous waste as:

A solid waste, or combination of solid wastes, which because of its quantity, concentration, or physical, chemical or infectious characteristics may - a) cause, or significantiy contribute to an increase in mortality or an increase in serious irreversible, or incapacitating reversible, illness; or b) pose a substantial present or potential hazard to human health or the environinent when improperly treated, stored, transported or disposed of, or otherwise managed.
\end{abstract}

\section{Characteristics of Hazardous Haste}

The U.S. Congress instructed (Section.3001, RCRA) the EPA to define a hazardous waste by (1) issuing criteria that would identify a substance as being hazardous and (2) compiling a list of hazardous wastes. The EPA identified four physical and chemical criteria by which a waste can be defined as hazardous: corrosivity, toxicity, flammability, and ignitability (40 CFR 261).

Mixtures of hazardous wastes and solid wastes are generally considered, in total, hazardous (40 CFR 261.3a). Exemptions are made when (1) the mixture no longer exhibits the hazardous characteristics of the original hazardous material or (2) the mixture is composed of wastes and wastewaters regulated under sections 402 and $307(\mathrm{~b})$ of the Clean Water Act (40 CFR 261.3a).

\section{Responsibilities of the Generator}

Generators must notify the EPA of all generated wastes and obtain an EPA identification number by submitting EPA form 8700-12 (40 CFR 261.12). Any spill cleanup of a hazardous material is considered the act of generating a hazardous waste; thus, EPA notification numbers are required. The EPA will issue an identification number over the phone for emergencies.

The company, industry, or individual generator is responsible for using the EPA testing protonsols to determine the hazardous or nonhazardous nature of all process wastes. However, the generator can apply general knowledge in deciding whether a waste is nazardous or not. If general knowledge is the sole determinant for the decision, the generator assumes all risk of error and may be subject to liability associated with this decision. In addition to manifests, the generator must package and label hazardous waste in accordance to EPA and Department of Transportation requirements (40 CFR 262.30262.33 cross referenced to 49 CFR 172-179). Generators are also required to keep three years of signed manifests, biennial reports, and test results of all produced hazardous wastes (40 CFR 262.40). 
Federal and State Hazardous Waste Regulations

Federal regulations for hazardous waste management are outlined in Part 40 of the Code of Federal Regulations. Sections relevant to the oil snale industry include:

40 CFR 260 Hazardous waste management systems - General 40 CFR 261 Identification and listing of nazardous wastes

40 CFR 262 Standards applicable to generators of hazardous waste

40 CFR 271 Requirements for authorization of state hazardous waste programs

40 CFR 272 Approved state nazardous waste management programs

Hazardous waste regulations for six states with potential for oil shale development are listed at the end of this section. Minimal federal requirements for authorized state hazardous waste programs are in 40 CFR 271. Those states with submitted and approved state hazardous waste programs are listed in 40 CFR 272.

\section{Proposed Federal Regulations}

Minimal federal hazardous waste management guidelines for oil shale retorting by-products are currently exempt from hazardous waste regulations. On october 21, 1980, Public 1aw 96-482 amended the Resource Conservation and Recovery Act, including the Revill Amendment, which excluded "solid waste from the extraction, beneficiation, and processing of ores and minerals" from regulatory provisions issued under RCRA. The status of this exclusionary ruling has been in litigation and controversy since its inception. The EPA wrote a preamble and interpreted the intent of Congress as excluding "solid waste from the exploration. mining, milling, smelting and refining of ores and minerals" $\left(45^{\circ} \mathrm{FR}\right.$ 76619). In an Uctober 1985 proposal (50 FR 40292), the EPA advocatcd eliminating many wastes froill this exclusion and relisting six smelting wastes as hazardous. Shortly thereafter (October 9), the EPA proposal was withdrawn; the EPA cited the need for further study on high volume-low hazard wastes. However, on December 16, 1986, the EPA was sued by the Hazardous Waste Treatment Council to reimpose its original (1985) restrictions.

Synfuel operations are directly affected by the Bevill Amendment exclusionary rule. An interpretive letter from the EPA (Welles 1984) states that the Bevill Amendment applies to oil shale industries:

The exemption can be viewed as extending to any unit operation including physical, chemical or biological processes wich process an ore or mineral in the dictionary sense of those terms. This includes the retorting of shale. 
...The exemption, however, does not extend to wastes resulting from the upgrading or refining of the crude oil extracted from shale, cleanup or enrichment of the gas, or other synfuels processes not associated with processing the shale.

Barring further changes in ore waste exemptions, most retort-related wastes should fall under this exemption.

\section{State Hazardous Haste Management Guidelines}

\section{COLORADO}

State Agency to Contact

Department of Health

Radiation and Hazardous Waste Control Division

4210 East 11th Avenue

Denver, CO $80220 \quad$ (303) 320-8333

Applicable State Laws or Statutes

Colorado Hazardous Waste Act

Colorado Revised Statutes

Title 25, Health and Safety

Article 15, Hazardous Wastes

Resulting State Regulations or Rules

Colorado Hazardous Waste Management

Code of Colorado Regulations

Title 5, Department of Health

Cnapter 1007, Article 3 - Hazardous Waste

\section{INDIANA}

State Agency to Contact

Solid Waste Management Board

P. n. Rox 1964

1330 Michigan Street

Indianapolis, IN 46202

Applicable State Laws or Statutes

Indiana Hazardous Waste Act

Indiana Code, Title 13 - Environment

Chapter 7 - Environmental Management 
Resulting State Regulations or Rules

Indiana Hazardous Waste Management Regulations

Indiana Administrative Code, Title 320

Article 4.1 - Hazardous Waste Management

\section{KENTUCKY}

\section{State Agency to Contact}

Department of Natural Resources and

Environmental Protection

Division of Waste Management

1121 Louisville Road, Pinenill Plaza

Frankfort, KY $40601 \quad$ (502) $564-6716$

Applicable State Laws or Statutes

Kentucky Garbage and Refuse Disposal Law

Kentucky Revised Statutes

Title IX, Chapter 109 - Solid Waste Management

Resulting State Regulations or Rules

Kentucky Administrative Regulations Title 401

Department of Environmental Protection

Chapters 30-47

OHIO

State Agency to Contact

Environmental Protection Agency

Office of Land Pollution Control

P.0. Box 1049

361 East Broad Street

Columbus, $\mathrm{OH} 43216 \quad$ (614) $166-7220$

Applicable State Laws or Statutes

Unio Solid and Hazardous Waste Disposal Law

Title 37, Health and Safety

Chapter 34, Solid and Hazardous Waste Laws

Resulting State Regulations or Rules

Unio Hazardous Waste Management Regulations

Unio Administrative Title 3745

Chapters 50-69 Hazardous Waste Management Regulations 
State Agency to Contact

Department of Health

Division of Environmental Health

Bureau of Solid Waste Management

150 West North Temple Street

P.0. Box 2500

Salt Lake City, UT $84110 \quad$ (801) $533-4145$

Applicable State Laws or Statutes

Utah Solid and Hazardous Waste Act

Utah Code - Annotated

Title 26 - Health Chapter 14, 106

Resulting State Regulations or Rules.

Utah Solid Waste Disposal Regulations

Utan State Board of Health Code of Solid

Waste Disposal Regulations

Adopted July 17, 1974

\section{WYOMING}

State Agency to Contact

Department of Environmental Quality

Solid Waste Management Program

401 West 19th Street

Cheyenne, WY 82002

(307) $777-7753$

Applicable State Laws or Statutes

Wyoming Environmental Quality Act

Wyoming Statutes

Title 35 - Public Health and Safety

Chapter 11 - Wyoming Environmental Quality Act

Resulting State Regulations or Rules

Rules and Regulations of the Wyoming Department of Environmental Quality, Solid Waste Management

Program - Chapter 1 


\section{RECLAMATION OF MINES \\ by John fordin}

The Surface Mining Control and Reclamation Act of 1977 created a system for publishing rules for reclamation after mining activities. The program is administrated by the states subject to approval by the federal government. Before the state issues a permit to mine, the facility must first collect baseline data on hydrology, water quality, vegetation, wildlife, including endangered species (e.g., Wyoming requires a survey of prairie dog populations in case the endangered black-footed ferret may be present), and cultural activities. The facility must develop a plan to return the land to baseline or better conditions after mining has ceased. The state reviews the permit application and will usually request additional information from the applicant. This is usually followed by a public hearing, and then a permit to mine is issued. Different procedures are followed in some states (e.g., Colorado, Utah), depending upon the size of the mine. In Wyoming, in situ operations are included under provisions of the Surface lining Control and Reclamation Act. 


\section{ENVIRONMENTAL IMPACT STATEMENTS \\ Dy John Nordin}

All major construction projects, including shale oil plants, will require an Environmental Impact Statement (EIS) which is authorized by the National Environmental Policy Act of 1970. Granting permits for activities such as construction, water use, and waste disposal is included under the Act. States also have requirements or issues that must be addressed in the EIS. The EIS must be completed before many federal and state permits will be granted. Environmental Impact Statements already prepared for oil shale projects are listed in the Phase 4 section.

In 1973, the Council on Environmental Quality (authorized by the Act) recommended the following format for the EIS:

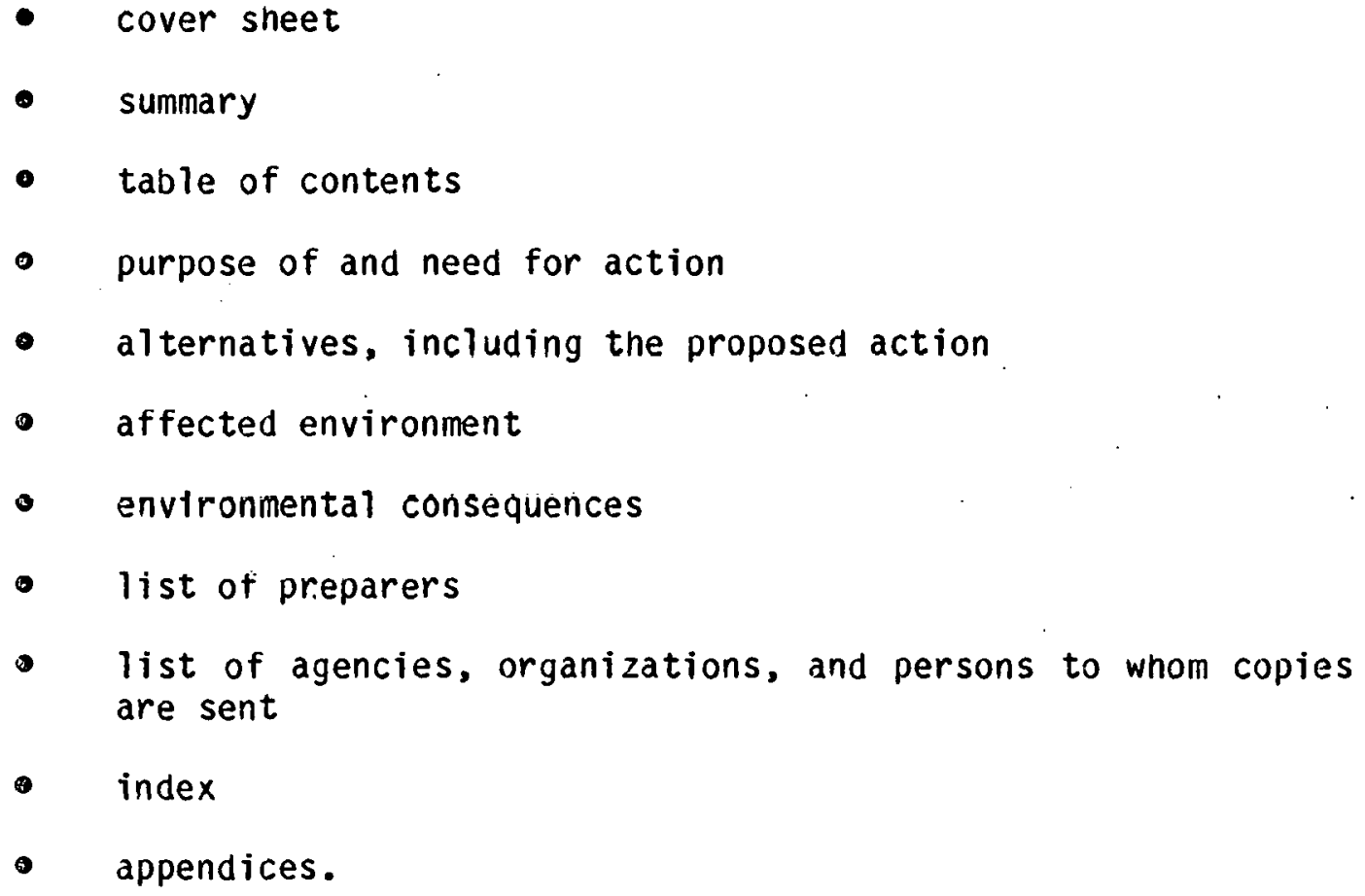

The steps for preparing an EIS are as follows:

1. The appropriate federal and state agencies are informed of the plans to construct a shale oil plant. Federal agencies include the U.S. Army Corps of Engineers (if the activity includes excavation, dredging, or disposal in navigable waters), U.S. Department of Energy, U.S. Department of Interior, and U.S. Environmental Protection Agency.

2. A federal agency prepares an environnental assessment based on information supplied by the developer on whether an EIS is necessary. This action takes about a month. If an EIS is not required, the agency can issue a Finding of No 
Significant Impact. A 30-day wait period is required for other agencies to respond. If the conclusion is disputed by other agencies, an EIS may have to be prepared anyway.

3. If an EIS. must be prepared, a Notice of Intent is filed in the Federal Register. This allows public participation in the approval process.

4. The EIS is prepared by an appropriate federal agency based on information supplied by the developer. A federal agency can prepare an EIS jointly with a state or local agency or another federal agency or adopt another agency's EIS.

Typically, an outside environmental consultant is nired by the agency to prepare the tIS which the applicant pays for. The agency manages the consultant's work. The selection of the consultant may be a joint decision by the agency and the applicant. Sometimes the applicant nires the consultant directly, and the consulting firm prepares a preEIS (sometimes called an Environmental Information Document) for the agency. The environmental consultant must be impartial and have no financial or other conflicting interest in the project.

5. The EIS must include environmental baseline studies on the following:

- air quality/elimatology/meteorology/noise

- water quality/hydrology

- geology/topography/soils/seismology.

- biology/terrestrial and aquatic

- socioeconomics/demography/land use

- nistory/archeology

At least one year is required to complete environmental baseline studies.

The EIS must contain a description of now each of these areas is affected, including a statement on adverse environmental effects that cannot be avoided. The relationship between short-term uses of the environment and maintenance and enhancement of long-term productivity must be addressed.

6. After the draft EIS is prepared, the agency file is entered in the Federal Register, and, at the same time, the draft EIS is distributed to interested parties. A public nearing is typically neld on the project. A 90-day wait period is required after publishing the notice in the Federal Register to allow interested parties to respond. 
7. After the agency receives all comments on the draft EIS, it analyzes them and modifies the EIS before the final EIS is issued. A 30-day wait period 'is allowed for review.

8. The EPA reviews all draft and final EIS's and then ranks them according to "environmental impact of the action" and "adequacy of the impact statement."

9. Based on the EIS and a11 comments received, the agency decides which course of action will be followed. This is included as a public record of decision.

10. If the EIS is rejected, changes in the project must be made in order to meet all environmental objections.

11. After the federal agency's final EIS is approved, the developer must still obtain the necessary federal, state, and local permits.

A list of EIS regulations is given below:

1. Council on Environmental Quality, National Environmental Policy Act; Regulations of Procedural Provisions: 40 CFR Parts $1500-1508$.

2. U.S. Environmental Protection Agency, Implication of Procedures on the National Environinental Policy Act: 40 CFR Part 6.

3. U.S. Corps of Engineers, Dept. of the Ariny; Environmental Quality: Policy and Procedures for Implementing the National Environmental Policy Act: 33 CFR Part 230.

4. U.S. Dept. of Energy, Compliance with the National Environmental Policy Act; Final Guidelines: 45 Federal Register 20694, March 28, 1980, amended 45 Federal Register 53199, Aug. 11, 1980.

5. U.S. Dept. of Interior, National Environinental Policy Act; Revised Implementing Procedures, 45 Federal Register 27541, April 23, 1980. 


\section{HEALTH AND SAFETY \\ by Rhonda James, James Dean, and John Rordin}

0il shale retorting and shale oil refining operations are covered by the Occupational Health and Safety Act. Mining operations, whether surface or underground, are covered by the Federal Mine Safety and Health Amendment Act of 1977. The Federal Mine Safety and Health Amendment Act of 1977 also excludes operators and miners from provisions of the Occupational Health and Safety Act.

Before Congress passed the Federal Mine Safety and Health Amendment Act, work conditions in mines were governed by the Federal Metal and Nonmetallic Mine Safety Act and the Federal Coal Mine Healtin and Safety Act of 1969. The Department of Interior administered these laws through the Mining Enforcement and Safety Administration (MESA). Critics charged that a conflict of interest existed in the Interior Department since the Bureau of Mines was not responsible for promoting mine safety.

Critics also charged that non-coal miners received less protection than coal miners because adoption of health standards were not mandatory under the Non-coal Act. The Coal Act did not cover exposure to toxic substances, and neither Act required specific training for inexperienced miners. Labor leaders argued that miners did not enjoy many of the rights and safeguards granted other workers under the Occupational Safety and Health Act (OSHA), and mine operators complained of jurisdictional conflicts between MESA and OSHA.

In 1977, the Federal Mine Safety and Health Amendment Act (Public Law 95-164) ended the dissension between factions of laborers and quieted the critics (Commerce Clearing House 1977). Section 811 of the Act gives the Secretary of the Interior the power to develop health and safety standards for miners. The Federal Mine Safety and Health Amendment Act of 1977 includes the following:

1. amends the 1969 Coal Act;

2. repeals the 1966 Metal and Nonmetallic Act and places all J.S. miners, coal and non-coal, under the safeguard of one health and safety act;

3. retains the safety and health standards of both the Coal and Non-coal Acts;

4. transfers jurisdiction from the Mining Enforcement and Safety Administration of the Department of Interior to the Department of Labor as the Mine Safety and Health Adıninistration;

5. provides new procedures to expedite the rulemaking process;

6. strengthens the mechanisms for enforcing compliance; 
7. provides procedures for assessing and collecting civil penalties resulting from violations of mine safety and health regulations at all mining operations;

8. provides broad mandatory training for all U.S. miners; and

9. retains the 1969 Coal Mine Act provision that limits state participation in mine safety and health enforcement and expands the scope to include non-coal mines; therefore, states are able to enforce standards that do not conflict with federal regulations.

(Day 1979; Comnerce Clearing House 1977) 


\section{BIBLIOGRAPHY FOR HEALTH AND SAFETY}

Commerce Clearing House. "Federal Mine Health and Safety Act of 1977: Law and Explanation," Cnicago, IL: Commerce Clearing House, Inc., November 9, 1977.

Day, J. M. "The Federal Mine Safety and Health Act," Practicing Law Institute, 1979.

McElroy, F. E., ed. "Accident Prevention Manual for Industrial Operations," National Safety Council, 1981.

\section{Applicable Permits:}

1. Modification of Commencement of Open Pit Mining. Regulation 30 CFR Part 55. Mine Safety and Health Administration.

2. Notification of Closing of Open Pit Mine. Regulation 30 CFR Part 55.26. Mine Safety and Health Adininistration.

3. Notification of Commencement of Subsurface Mining. Regulation CFR Part 57. iline Safety and Health Administration.

4. Notification of Closing of Subsurface Mine. Regulation 30 CFR Part 57.26. Mine Safety and Health Administration.

5. Permit for Importing, Manufacturing, or Dealing in Explosives. Regulation 27 CFR Part 181 et seq. U.S. Treasury Department, Bureau of Alcohol, Tobacco, and Firearms.

6. Colorado Permit for Handling Explosives. Regulation 7 CCR 1101-9 (Colorado). Colorado Division of Labor, Department of Labor and Employment.

7. Colorado Permit for Operation of Diese1-Powered Equipment Underground. Regulation 2 CCR 403-1 (Colorado). Colorado School of Mines.

8. Utah Permit for Handling of Explosive Materials. Regulation UCA 1953 Part 17-5-36. Utah Board of County Commissioners.

9. Utan License for Storage of Explosives. Regulation UCA 1953. Part 40-5-4. Utah Industrial Comnission.

10. Utan Perinit for Transportation of Explosives. Regulation UCA 1953. Part 41-5-154. Utan Public Service Commission.

11. Wyoming Purchase of Explosive Materials Regulation WS 1977 Part 35-16-102. State of Wyoming. 
12. Wyoming also has permits for opening and closing mines and reporting procedures for mining accidents, change of mine ownership, etc.

13. Kentucky, onio, Indiana, and other states have similar permits for handling or using explosives or operations in mines.

14. States also nave permits, licenses, or approvals of inspection required to operate food services, health care facilities, open burning facilities, electrical inspections, etc. 


\section{SOCIOECONOMIC RESTRICTIONS REGARDING LAND USE by Audie Blevins}

Generally, local, state, and federal statutes fail to directly address socioeconomic issues independently of other siting issues. In fact, socioeconomic issues tend to be add-ons to other siting considerations. A brief discussion of legislative restrictions related to socioeconomic issues follows.

\section{Federal Response}

The basic law governing land use for mining purposes was first established with the 1920 Federal Mining Law which set aside $50 \%$ of all federal lease monies for redistribution to local areas to assist in planning for large scale extraction industries. Thus, rather than a restriction, this law is best seen as an instrument of mitigation.

More recent federal regulation is in the National Environmental Policy Act of 1969 (P.L. 91-190,42 U.S.C. 4321 et seq.) which established guidelines for developing Environmental Impact Statements (EISs) for large scale industrial developments involving federal lands or federal permitting (utility lines). The EIS includes a study of possible socioeconomic impacts (both positive and negative) of the proposed project. Section 101 of NEPA recognizes the importance of fulfilling "the social, economic and other requirements" of U.S. citizens.

Section $102(2)(A)$ of the act requires federal agencies to make 'integrated use of the natural and social sciences... in decision making which may have an impact on man's environment.' Section $102(2)(C)$ requires that EISs--including 'integrated use' of the social sciences--be prepared for al1 'major federal actions significantly affecting the quality of the human environment' (Freudenburg and Keating 1985).

Freudenburg and Keating also note that Section 1508.8 of the Regulations for Implementing NEPA (U.S. Council on Environmental Quality 1978) requires that EISs consider direct and indirect social and cultural impacts, as well as environmental impacts (1985: 580). Recently, courts have decided that EISs must contain meaningful analysis of socioeconomic impacts of large scale developments involving federal agencies (i.e., Northern Cheyenne Tribe v. Hodel, No. CV 82-116-BLG (D. Mont. May 28, 1985)).

\section{States' Response}

0il shale states have enacted different statutes and regulations governing shale development, particularly its potential socioeconomic impact on indigenous populations. For example, Wyoming (Van Baalen 1976) and Montana (Carter 1984) have enacted strong siting legislation for all types of large scale industrial developments which require environmental impact statements that address socioeconomic impacts. 
Colorado enacted impact mitigation types of legislation while Utah's siting legislation is designed to attract development (Lee 1983; U.S. Department of Energy 1981; Appendix A). In general, laws regulating oil shale development are identical to laws governing mining or large scale industrial siting. Statutes for the eastern oil shale region tend to be permissive rather than restrictive and, in most cases, ignore socioeconomic issues entirely except for mention of prime farin land and destruction of primary recreational areas (Appendix A).

To illustrate, a brief discussion of Kentucky, Colorado, and Wyoming follows.

Kentucky. Responsibility for regulating oil shale development is with the Department for Natural Resources and Environmental Protection which also regulates other types of surface mining. Actions of this cabinet are defined by KRS 350.010 and cover both surface mining of shale and in situ mining of oil snale as of June 30, 1981. Standards are mentioned for land, water, and air protection, but no mention is made of socioeconomic impacts per se. (Enact. Acts 1980, Ch. 260, \#1, effective July 15, 1980, for legislative authority)

By 1983 regulations for oil shale operations were enacted under 405 KAR Chapter 30: 0il Shale Regulations. Responsibility was shared jointly by the Department for Surface Mining Reclamation and Enforcement and the Natural Resources and Environmental Protection Cabinet (Commonwealth of Kentucky). This document does not specify socioeconomic issues; nowever, ecological, historic, archaeological, health and safety, and farmland use are discussed. For example, section 240-02 requires greenbelts in reclaiming "residential, public service, or industrial land use." Section 110-01 allows for public participation in inspection and enforcement of regulations. Kentucky is one of the states that pays little heed to the socioeconomic issues of oil shale development.

Colorado. Colorado has a dual response: The development of its natural resources are encouraged, but socioeconomic disruptions to local residents that such development might create are ininimized by state programs. According to Lee (1983), Colorado energy resource development policies fall into several categories which are related to socioeconomic goals:

strengthen local government and encourage local initiative,

provide financial and technical assistance to rural areas,

coordinate private, federal, state, and local government efforts to provide adequate housing in impacted areas,

encourage land used decisions at the local government level,

ensure minimum environmental degradation, minimum socioeconomic impacts, and efficient recovery of the resources, and 
require that the burdens of energy resource development be distributed as equitably as possible...to minimize the socioeconomic costs associated with large scale energy resource development on the local community.

The Department of Natural Resources, where the Mined Land Reclamation Board is located, is the primary agency charged with monitoring energy development and its impacts.

In addition, colorado has established a number of funding sources for energy impacted communities, including the Mineral Impact Fund (Colo. Rev. Stat. 34-63-102, Supp. 1982) and the 0il Shale Trust Fund. These efforts can enhance resource development since monies can be used to mitigate possible socioeconomic impacts in local communiries.

Severance taxes from colorado shale oil producers are deposited in the Colorado 0il Shale Trust Fund. The state legislature moves these moneys to the Impact Fund which makes grants to communities affected by oil shale development for capital projects such as schools, sewers, and roads, and for economic development.

Wyoming. Wyoming has developed stringent regulations and safeguards designed to minimize negative socioeconomic and environmental effects of energy development. Key to these safeguards is the principle that beneficiaries of development should bear the social and capital costs of development. The Industrial Development Information and Siting Act is primarily responsible for developing and enforcing safeguards. The Act is administered by the Industrial Siting Council (35-12-102 (1977, Supp. 1981, Supp. 1987). All firms of given size (\$SU million in 1977) must obtain a permit from the Council. The permit application requires extensive information, including "a method to avoid adverse socioeconomic and environinental impacts covering 15 specific areas of concern" (35-12-108) (Lee 1983). Some of the areas of concern are law enforcement, fire protection, nealth care facilities and personnel, recreational facilities, library facflities, housing, transportation, human services, educational facilities, and government and public tinance. In addition, the petitioner must specify population impacts and economic benefits of the proposed project. Petitioners must also establish an acceptable monitoring prograin for the above 15 socioeconomic areas (Appendix A). Of the states exainined, Wyoming has the most detailed regulations governing resource development, requiring industries to address specific socioeconomic impacts and monitor such impacts.

Summary. Some states have no socioeconomic statutes; others have statutes that encourage development because of potential economic benefits to the state, in general, and perhaps to the local area. other states require extensive environmental impact statements and proposed mitigation plans before permits will de issued (e.g., Wyoming). Finally, states such as colorado impose few constraints on development but do require companies to participate financially in mitigation of negative impacts on indigenous populations. 


\section{Local Statutes Regarding Land Use}

Local responses to proposed oil shale developments are primarily concerned with zoning regulations at the county or municipal level (Pelnam 1979). Local zoning laws have a long history, the first being established in 1916, and vary tremendousiy from state to state. Generally, the Supreme Court has upheld the right of local governments to zone land use for the health and well-being of its citizens. Since these regulations vary so much, only Colorado's broad regulations will be discussed.

\section{Colorado's Local Response}

Presently, Colorado does not have a siting act; however, it does regulate resource development through land use legislation and by the Department of Public Natural Resources and the Department of Public Health. The State Land Use Commission sets land use policy; however, in practice, authority is implemented through local zoning ordinances (Lee 1983; Marston 1984). Local governments are also instrumental in applying for and administering the mitigation funds available at the state level (section 2.11.2.2.). These monies come from the 0il Shale Trust Fund, which was created from part of the monies paid for federal oil shale leases (funds mandated by the Federal Mineral Leasing Act of 1920). In addition, Colorado created the Local Government Lease Fund and Local Government Severance Tax Fund to assist local areas with impact problems (Scrimegeour 1980).

Garfield County, Colorado, where two oil shale projects are located (Exxon's Colony and Union Oil's Parachute Creek), has relied on existing zoning laws to regulate growth (Marston 1984). In 1982 the county created a Fiscal Impact Mitigation Program which requires future developments to "project future employment and population levels, identify public service needs, and develop initigation plans" (Marston 1984). Presently, the county is working under three systems: conditional use permits, planned unit development regulations, and rezoning. Rezoning requires that both 1 and-use and socioeconomic consideration be taken into account in issuing rezoning permits. County officials have also created phased perinitting which allows the project to be approved in steps so that it can be monitored. All of these efforts are designed to give local officials some input into large scale industrial developments and to ensure that mitigation plans are available so local populations will not be harmed by development.

\section{Private Response to Land Use}

For residents of many of the oil shale states, the only recourse to industrial development is that of individual action. Most state regulations designate that individuals who feel narmed by potential developments have the right to file complaints, to seek redress in the courts, or to make an appeal in public nearings (Appendix A). Generally, states have few provisions for citizen input regarding the siting of industrial developments; therefore, citizen action tends to be after-the-fact rather than during the planning and permitting 
stage. The lack of state legislation leaves both companies and. individuals in limbo regarding guidelines for development. Each project is considered unique and must undergo adversarial hearings to defend its proposed development without benefit of statutes of specification or performance. 


\section{ANTIQUITIES (CULTURAL RESOURCES) \\ by James Dean}

Cultural resources refers to the artifacts and sites of Native Americans prior to the arrival of Europeans and of nonnative Americans from their arrival in North America to 50 years ago. Cultural resources also refers to a process of laws and regulations which protect and enhance sites, artifacts, structures, and other evidence of the past. A variety of laws and regulations supports the programs in all federal agencies. These regulations are included to protect certain natural resources: paleontological resources (fossils and the areas where specific fossils are found), natural areas (areas of unique value for a rare or valuable resource not commonly recognized), and permit authorization for individuals and institutions wishing to study a specific resource in a certain area.

Western Shale Area

Piceance Basin, Northwestern Colorado

Based on an inventory of 78,000 acres $(9.6 \%$ of the area) at the Class III level (sample inventory), there are about 6600 sites in this area. The large area sampled so far is a result of development from energy demands. Most work has been done on individual energy development sites. It is not the result of a scientific area-wide inventory (BLM 1984). The following table summarizes the types of sites found in northwest Colorado (BLM 1984).

Historic remains in the area date from the nomesteading period (1ate 1800's) to 1935. During WW1, oil shale was developed in the Piceance Basin; these sites date from 1915. Thirty-four historic sites have been recorded since 1972, including cabins, corrals, schools, and other structures. There is one site on the National Reyister: Duck Creek Wickiup Village (5RB53). No other sites are nominated. About 35 sites have heen evaluated in the field to determine their eligibility, but none have been further evaluated (BLM 1984).

Paleontological resources in the area include verteirate fossils in the Morrison, Wasatch, Green River, and Williams Fork members of the Mesa Verde Group. Other fossils include such finds as plant remains, ammonites, insects, and petrified wood (BLM 1984). 
Table 18. Cultural Resource Site Types

\begin{tabular}{|c|c|c|}
\hline Function/Kind & Characteristics & Traditions \\
\hline Lithic scatter & $\begin{array}{l}\text { Waste from stone tool making, } \\
\text { broken tools, chips, etc. }\end{array}$ & Ai 1 \\
\hline Campsite & $\begin{array}{l}\text { Litnic scatter, charcoal } \\
\text { burnt bone, pottery, etc. }\end{array}$ & A 11 \\
\hline Quarry - & $\begin{array}{l}\text { Natural rock used for tonl } \\
\text { making, lithic scatter, etc. }\end{array}$ & A1 1. \\
\hline Kill site & Remains of animals, tools, etc. & $\begin{array}{l}\text { Llano and } \\
\text { Plano, all }\end{array}$ \\
\hline Rock she 1ter & $\begin{array}{l}\text { Area protected from weather by } \\
\text { rock overnang, contains drip } \\
\text { line }\end{array}$ & $\begin{array}{l}\text { Plano, Archaic } \\
\text { Fremont, } \\
\text { Protonist. }\end{array}$ \\
\hline Rock art & $\begin{array}{l}\text { Message or expression left } \\
\text { on a rock surface, painted } \\
\text { or cut with a rock chisel }\end{array}$ & $\begin{array}{l}\text { Archaic, } \\
\text { Fremont, } \\
\text { Protonist. } \\
\text { Historic }\end{array}$ \\
\hline Burial & Human remains & $\begin{array}{l}\text { Fremont, } \\
\text { Protonist. } \\
\text { Historic }\end{array}$ \\
\hline $\begin{array}{l}\text { Tipi rings, } \\
\text { wickiups }\end{array}$ & $\begin{array}{l}\text { Circular arrangement of rocks, } \\
\text { poles, or branches leaning against } \\
\text { rocks or living trees }\end{array}$ & $\begin{array}{l}\text { Protonist. } \\
\text { Historic }\end{array}$ \\
\hline Granary & $\begin{array}{l}\text { Sandstone slab structures built } \\
\text { into ledges, capped with slab }\end{array}$ & Fremont \\
\hline Rock walls & $\begin{array}{l}\text { Alignments of rock walls } \\
\text { laid dry or mortared, usually } \\
\text { built on a ridge. used as a fort }\end{array}$ & Fremont \\
\hline Corral & $\begin{array}{l}\text { Enclosure of wood with single } \\
\text { entrance, used to trap horses }\end{array}$ & $\begin{array}{l}\text { Protonist. } \\
\text { Historic }\end{array}$ \\
\hline Sweat lodge & $\begin{array}{l}\text { Cone-shaped structure of } \\
\text { brush and poles, fire cracked } \\
\text { rocks in front }\end{array}$ & Protonist. \\
\hline Homestead & $\begin{array}{l}\text { One or more structures of varied } \\
\text { sizes, shapes, and materials used } \\
\text { to shelter European families }\end{array}$ & Historic \\
\hline
\end{tabular}


Cultural traditions fall into several categories as follows:

Tradition

Time

(division at time of a certain

culture type)

$\begin{array}{ll}1776-50 \text { years ago } & \text { Historic; Ute } \\ 1250-1776 & \text { Protohistoric } \\ 900-1250 & \text { Fremont } \\ 2500 B C-900 A D & \text { Archaic } \\ 7000 B C-2500 B C & \text { Plano } \\ 10000 B C-7000 B C & \text { Llano }\end{array}$

Judging from the area already inventoried, the following generalities are evident concerning the relation between site densities and environmental zones:

topography is not a factor in predicting site location;

stream rank is a predictor of sites; density is nigher further upstream than along major streams;

the vegetation zone is important; density is nigher in pinyon-juniper and rabit brush-sagebrush zones;

relief is important; low relief usually nas more sites;

exposure is important; southern exposures have more sites than other directions;

soil type is not a factor; selection is based more on vegetation type.

\section{Northeast Utah}

The Utah snale area is in the Uinta Basin of the colorado Plateau. Human activity in the area is verified from $11,500 \mathrm{BC}$ to the present; over 1300 sites have been identified. Site densities are highest in the pinyon-juniper zone; sagebrush has a medium density; and oakbrush, mountain, and shadescale zones have lowest densities. Based on a 1980 study, site density has a range of 1.5 to 0.7 sites per square inile. The nature of the sites indicates that nunters and gatherers were present (BLM 1983).

Mineral development in 1886 led to subsequent mining and settlement by white settlers. Sites include inines, early stockman camps, and early railroad and telegraph lines (BLM 1983). 
Paleontological resources include important fish, reptile, bird, and mammal fossils, mostly in the Green River and Uinta formations (BLM 1983).

\section{Southwest wyoming}

Inventories and studies indicate that about $16 \%$ of the identified sites in southwest Wyoming may be eligible for inclusion on the National Register; over 600 sites have been tested. About $10 \%$ of the sites are historic, mainly homesteads; the rest are prenistoric (BLin 1982).

\section{Eastern Shale Area}

The eastern shale area has a mucn different mistury of inumall occupation. This is understandable due to the much different environment: humid climate, woodland vegetation, and rolling topography with many rivers and streams.

\section{Native Americans}

Prior to $5,000 \mathrm{BC}$, most evidence of early man comes from kill sites and deeply stratified cave deposits. The eastern area was part of the domain of the Eastern Fluted Point Hunters, tribes of huntergatherers. By 4,000 BC, eastern hunter cultures had evolved into regional groups who lived by small game nunting, fishing, and gathering wild plants. Mill stones becane evident as wild seeds became more important in the diet. Wandering from place to place, these peoples moved to where food was most abundant. From $500 \mathrm{BC}$ to $500 A D$, maize agriculture and settled village life developed in the area. The Hopewell and Adena of the Unio Valley developed at this time. By $500 \mathrm{AD}$ to $1300 \mathrm{AD}$, long experience with domestic crops led to leisure and a flowering of culture. The Eastern Village farmer culture developed into the Early Mississippi Cultures. Ceremonial centers such as Early Fort Ancient and Harmons Creek were established, with stone carvings, shellwork, textiles, and pottery. Language groups by this time included Shawnee, Yuchi, and Cherokee (USǴS 1970).

\section{European Man, Early 1500 's to 50 Years Ago}

Following about 200 years of exploration and occasional visits, white men settled in the eastern area. By 1800, much of the Onio Valley was settled, and by 1835, the entire region had been settled. Some of the most significant dattles of the Civil War were fought in the area (USGS 1970).

\section{The National Register Process}

The body of laws which protect and enhance the cultural resources of the U.S. is dictated by the National Historic Preservation Act of 1966. The Act requires the Secretary of the Interior to establish a National Register of significant sites. Executive Order 11503 (May 13, 1971) required federal agencies to inventory and nominate the National Register cultural sites under their jurisdiction and, if 
threatened by development, to consult with the Advisory Council on Historic Preservation prior to implementation of the proposed action (USDI 1978).

A summary of the National Register process follows:

1. The Program

Sites with national, state, or local significance can be nominated to the National Register by federal agencies with the approval of the Secretary of the Interior.

2. Criteria for Nomination

Quality of sites or artifacts is a result of important nistorical events, is associated with nistorically important people, is a result of unique characteristics, or is because they have yielded or may yield information important in history or prehistory.

Certain ordinary properties do not meet the criteria, and any site must be over 50 years old.

3. State Nominations

States nominate through the State Historic Preservation officer in each state. SHPO's al so review federal projects for impacts on historic sites in the state.

4. Federal Nominations

The Secretary of the Interior nominates federal sites.

5. Advisory Council on Historic Preservation

The Advisory Council is an independent agency of the executive branch.

6. Publication of the List

The list is updated annually in the Federal Register on the first Tuesday in February. 


\section{BIBLIOGRAPHY FOR ANTIQUITIES}

BLM. Resource Management Plan and Environmental Impact Statement, Piceance Basin Planning Unit, White River. Resource Area, Craig District, CO, 1984.

BLM. Environmental Impact Statement, Uinta Basin Synfuels Development, Utah State Office, SaTt Lake City, UT, 1983.

BLM. Green River-Hamms Fork Regional Coal EIS, Colorado and Wyoming State Officers, Denver, CO, and Cheyenne, WY, 1981.

Department of the Interior. The National Atlas of the United States of America, leological Survey, 1970.

Department of the Interior. "The National Register of Historic Places," 1978. 


\section{PERMITS TO DEVELOP RESOURCE}

In 1979, the DUE contracted with Science Applications, Inc., of Golden, Colorado, to prepare a two-volume report, "Development and Application of a Permit Information System for snale 0il (PERMISSO)." That work lists various governmental permits, licenses, and other approvals required for oil shale development in colorado, Utah, and Wyoming. The list was current as of July 1978 and identifies more than 400 permits, licenses, and approvals pertinent to oil shale development. A flow chart was included to guide the developer through the permitting process.

WRI contracted with Mr. Larry Harrington, Attorney at Law, Casper, Wyoming, to update the permit information system using the same format and permit classification scheme as in the 1979 PERMISSU reports. The update is incorporated as Appendix $A$ of this report. The permit classification scheme is as follows:

$\begin{array}{ll}\text { Federal } & 01000-01999 \\ \text { Colorado } & 02000-02999 \\ \text { Utan } & 03000-03999 \\ \text { Wyorning } & 04000-04999 \\ \text { Counties } & 05000-19999 \\ \text { Onio } & 20000-20999 \\ \text { Indiana } & 30000-30999 \\ \text { Kentucky } & 40000-40999\end{array}$

The permits listed in Appendix $B$ are in addition to those described in the original PERMISSO document and are current as of 1987.

The PERMISSO update does not include county and other local level requirements. Other areas not covered are water rights, rights-ofway, easements, requirements for Indian lands, BLM 1ands, and nonattainment areas. Only Colorado, Wyoming, Utan, Kentucky, Indiana, and Onio are covered.

Reference: Science Applications, Inc. "Development and Application of a Permit Information System for Shale 0il (PERMISSU)," Golden, CO, DUE/ET/83764-1, Ju1y 1979. 
PHASE 3. PROCESS TECHMOLOGY FOR OIL SHALE DEVELOPMENT 


\section{GENERAL DESCRIPTION OF PROCESS TECHNOLOGY by John Nordin}

0il shale processing technology falls into three categories:

1. mining of oil shale followed by surface processing;

2. modified in situ retorting--a portion of the oil shale is mined creating a cavity; the shale is then rubblized and retorted underground; product oil and/or gases are collected;

3. true in situ retorting--the shale is not mined but is fractured in place using explosives and/or water and, in some situations, chemicals, and then retorted underground.

Mining may be on the surface (open pit) or underground. The typical underground mine uses the room-and-pillar method, with rooms 55 feet wide by 60 feet high with approximately $60 \%$ overall resource recovery (Lindquist 1982). Surface retorting may be either a direct neating process or an indirect neating process. The direct neating process uses heat generated by combustion of residual char in retorted shale to retort fresin shale. An indirect heating process uses steam, not gases, ceramic balls, or other media to transfer heat to the shale to be retorted.

Eastern shale (Denovian) contains a much nigher carbon-tohydrogen ratio than Western shale (Green River Formation). For a surface retorting process in an inert atmosphere, oil yields are typically 10 gallons per ton (gpt) compared with 25-35 gpt for Green River Formation shale. If an eastern shale is reacted with a hydrogen donor solvent or retorted in a hydrogen atmosphere, yields are increased. 0il yields in excess of $200 \%$ of the Fischer Assay (25-29 gpt of eastern shale) are reported for the HYTORT process (Punwani 1986). The HYTURT process, developed by the Institute of Gas Technology (IGT), retorts shale in a hydrogen atmosphere at hydrogen pressures of 400-800 psig (28.2-55.4 atm). The IGT and the HYCRUDE Corporation (a second-tier subsidiary of IGT) calculate that over $90 \%$ of the total organic carbon in the shale is converted to gaseous and liquid products for the HYTURT process. This compared with about a $30 \%$ conversion when eastern shale is retorted in a nitrogen atmosphere (Anined 1982). Rubel at al. (1987) obtained 55\% to 60\% conversion retorting eastern shale using steam to enhance conversion. Retorting eastern shale typically produces more gaseous products, more residual char, and less liquid than Green River oil shale. Process technologies are listed in Tables 19 through 25. 
Table 19. Oil Shale Mining

\begin{tabular}{|c|c|c|}
\hline Type & Description & References \\
\hline General article & $\begin{array}{l}\text { Effect of mining strategy } \\
\text { on profitability }\end{array}$ & Studebaker 1985 \\
\hline Surface & Piceance Basin & Lewis 1980 \\
\hline Surface & Colorado & Suntech Inc. 1976 \\
\hline Surface & Montgomery Co., Kentucky & Kruspe 1980 \\
\hline Surface & Eastern and western US & Lindquist $1982^{\circ}$ \\
\hline Surface & Alabama shales & Hilleke 1982 \\
\hline Surface & $\begin{array}{l}\text { Comparison to coal mining } \\
\text { in eastern U.S. }\end{array}$ & Bender 1982 \\
\hline Surface & Open pit mining of deep shale & Banks 1985 \\
\hline Surface & Western US, siting & Ketron Inc. 1981 \\
\hline Surfacc & $\begin{array}{l}\text { Only workable method is to } \\
\text { strip mine (Kentucky) }\end{array}$ & Lind 1981 \\
\hline Surface & Cost analysis & Resnick 1981 \\
\hline $\begin{array}{l}\text { Surface } \& \\
\text { Underground }\end{array}$ & Piceance Basin & Miller 1984 \\
\hline Underground & Piceance Basin, room and pillar & Lewis 1980 \\
\hline Underground & $\begin{array}{l}\text { Eastern and western U.S., } \\
\text { room and pillar }\end{array}$ & Lindquist 1982 \\
\hline Underground & $\begin{array}{l}\text { Western U.S., Tosco II surface } \\
\text { retorting }\end{array}$ & $\begin{array}{l}\text { Denver Research } \\
\text { Institute } 1983\end{array}$ \\
\hline Underground & $\begin{array}{l}\text { Economics, deep thick oil } \\
\text { shale deposits }\end{array}$ & Hoskins 1986 \\
\hline Underground & Western U.S. & Ketron Inc. 1981 \\
\hline Underground & Cost analysis & Resnick 1981 \\
\hline
\end{tabular}


Table 20. Surface Retorting Technologies--Direct Heating

\begin{tabular}{|c|c|c|c|}
\hline Type & Developer & Description & Reference \\
\hline $\begin{array}{l}\text { Direct } \\
\text { (Union A) }\end{array}$ & Union A & Union $B$ development & Cha 1982 \\
\hline $\begin{array}{l}\text { Direct } \\
\text { (Superior) }\end{array}$ & Superior & $\begin{array}{l}\text { Eastern Shale Technology } \\
\text { Garfield, Co }\end{array}$ & $\begin{array}{l}\text { Boyda } 1982 \\
\text { Boyda } 1979 \\
\text { Superior 0i1 } \\
\text { Co. } 1983\end{array}$ \\
\hline $\begin{array}{l}\text { Direct } \\
\text { (Paraho) }\end{array}$ & $\begin{array}{l}\text { Paraho } \\
\text { Development Corp }\end{array}$ & $\begin{array}{l}\text { Eastern shale } \\
\text { Eastern shale } \\
\text { Eastern shale } \\
\text { Eastern shale } \\
\text { Alabama shale } \\
\text { Western shale } \\
\text { Eastern shale } \\
\text { General article } \\
\text { Eastern shale }\end{array}$ & $\begin{array}{l}\text { Boyda } 1982 \\
\text { Greaves } 1983 \\
\text { Reeves } 1982 \\
\text { Anmed } 1982 \\
\text { Hilleke } 1982 \\
\text { Frumkin } 1979 \\
\text { Parkinson } 1984 \\
\text { Pforzheimer } 1974 \\
\text { Vyas } 1981\end{array}$ \\
\hline $\begin{array}{l}\text { Direct } \\
\text { (T3) }\end{array}$ & Used in Morocco & $\begin{array}{l}\text { Applicability to eastern U.S. } \\
\text { snale }\end{array}$ & Cna 1982 \\
\hline
\end{tabular}


Table 21. Surface Retorting Technologies--Indirect Heating

\begin{tabular}{|c|c|c|c|}
\hline Type & Deveroper & Description & Reference \\
\hline Indirect (Tosco II) & Tosco Corp. & Applicability to easterri U.S. & Pease 1982 \\
\hline Indirect (Tosco II) & Tosco Corp. & Applicability to eastern U.S. & Parkinson 1984 \\
\hline Indirect (Tosco II) & Tosco Corp. & Emphasis on pollution ccntrol & $\begin{array}{l}\text { Denver Research } \\
\text { Institute } 1983\end{array}$ \\
\hline Indirect (Union $B$ ) & Union Uil Co. & $\begin{array}{l}\text { Mathematical modeling by } \\
\text { Lawrence Livermore Naticnal } \\
\text { Laboratories }\end{array}$ & Braun 1985 \\
\hline Indirect (Superior) & Superior $0 i 1$ Co. & Applicability to easterr. U.S. & Reeves 1982 \\
\hline Indirect (Allis-Chalmers) & Allis-Chalmers & $\begin{array}{l}\text { Indiana } 500 \text { bpd } \\
\text { Demonstration plant }\end{array}$ & Raymond 1987 \\
\hline Indirect (Dravo) & Dravo Circular Erate & Means 0il Shale Project & $\begin{array}{l}\text { Lloyd } 1984 \\
\text { Forbes } 1985\end{array}$ \\
\hline Indirect (Paraho) & $\begin{array}{l}\text { Parano Development } \\
\text { Corp. }\end{array}$ & Eastern shale & $\begin{array}{l}\text { Greaves } 1983 \\
\text { Reeves } 1982 \\
\text { Parkinson } 1984\end{array}$ \\
\hline Indirect (Paraho) & Paraho Development Corp. & Western shale & Frumkin 1979 \\
\hline Indirect (Parano) & Paraho Development Corp. & Technology assessment & Thumann 1981 \\
\hline Indirect (Petrosix) & American Sun-Crude & $\begin{array}{l}2150 \text { shale oil plant } \\
\text { in southeast Indiana }\end{array}$ & $\begin{array}{l}\text { Eitel } 1985 \\
\text { Boyda } 1982 \\
\text { Humphrey } 1983\end{array}$ \\
\hline Indirect (Petrosix) & & Applicability to Kentucky shale & Ivo 1983 \\
\hline Indirect (IGT Free Fall) & IGT & U.S. pateñ $4,578,176$ & Tarman 1986 \\
\hline Indirect (Cyclone) & DOE & U.S. patent $4,340,463$ & Harak 1984 \\
\hline Indirect (solar) & Lawrence Livermare Lab & Solar retorting & Gregg 1980 \\
\hline Indirect (steam) & G.A. technologies & Direct steam retorting & Rao $1983^{\circ}$ \\
\hline
\end{tabular}


Table 22. Surface Retorting Technologies--Hydrogen Enrichment

\begin{tabular}{|c|c|c|c|}
\hline Type & Developer & Description & Reference \\
\hline Hydroretorting & Hycrude Corp. (IGT) & $\begin{array}{l}\text { Eastern oil snale } \\
\text { retorted in hydrogen } \\
\text { atmosphere in lab } \\
\text { scale batch reactor } \\
\text { yield about } 200 \% \\
\text { of Fischer assay, gas } \\
\text { product }\end{array}$ & $\begin{array}{l}\text { Penwani } 1986 \\
\text { Boyda } 1982 \\
\text { Humphrey } 1983 \\
\text { Schora } 1983 \\
\text { Anmed } 1983 \\
\text { Parkinson } 1984 \\
\text { Vyan } 1981\end{array}$ \\
\hline Hydroretorting & IGT & $\begin{array}{l}\text { New Albany shale } \\
\text { retorted in hydrogen } \\
\text { atmosphere, gas product }\end{array}$ & Lau 1987 \\
\hline Hydroretorting & Hycrude Corp. (IGT) & $\begin{array}{l}\text { Hydroretorting plus } \\
\text { Deneficiation (froth } \\
\text { flotation) }\end{array}$ & Lamont 1987 \\
\hline Hydroretorting & Hycrude Corp. (IGT) & Alabama shales & Hilleke 1982 \\
\hline Hydroretorting & & Low grade shales & Green 1985 \\
\hline Hydroretorting & & $\begin{array}{l}\text { Application to oil } \\
\text { shale worldwide }\end{array}$ & Janka 1985 \\
\hline Hydroretorting & & General, eastern shale & Punwan 1986 \\
\hline Hydroretorting & & HYTORT process model & $\operatorname{Rex} 1984$ \\
\hline $\begin{array}{l}\text { Hydrogenation } \\
\left(H-E^{m+} \text { Process }\right)\end{array}$ & Triad Research, Inc. & $\begin{array}{l}\text { Preneat, nydrogenation } \\
\text { extraction of oil from } \\
\text { Devonian shales }\end{array}$ & Addington 1985 \\
\hline Hydrogenation & Gulf Research & $\begin{array}{l}\text { Use of hydrogen donor } \\
\text { solvents, eastern } \\
\text { shale oil production }\end{array}$ & Cronauer 1984 \\
\hline
\end{tabular}


Table 23. Surface Retorting Technologies--General

\begin{tabular}{|c|c|c|c|}
\hline Type & Researcher & Description & Reference \\
\hline General & Kentucky Energy Lab & $\begin{array}{l}\text { Effect of steam on } \\
\text { retorting }\end{array}$ & Rubel 1987 \\
\hline General & DOE (Morgantown) & DUE funded projects & Bartke 1987 \\
\hline Bibliography & $\begin{array}{l}\text { Laramie Energy } \\
\text { léchnology lenter }\end{array}$ & $\begin{array}{l}\text { Bibliography tnrough } \\
19 / y\end{array}$ & LETC 1980 \\
\hline General & & Review & Duir 1983 \\
\hline Beneficiation & & General article & $\begin{array}{l}\text { Fuel and } \\
\text { Mineral Res. } \\
\text { Inc. } 1982\end{array}$ \\
\hline General & & General discussion & Hendrickson 1974 \\
\hline Beneficiation & Univ. of Florida & $\begin{array}{l}\text { Beneficiation prior to } \\
\text { retorting }\end{array}$ & Moudgil 1982 \\
\hline Beneficiation & & $\begin{array}{l}\text { Beneficiation prior to } \\
\text { retorting }\end{array}$ & Reeves 1984 \\
\hline Combustion & & $\begin{array}{l}\text { Combustion of oil } \\
\text { shale }\end{array}$ & Koeck 1982 \\
\hline General & & General assessment & Sladek 1980 \\
\hline General & & Technology assessment & Thuman 1981 \\
\hline
\end{tabular}


Table 24. In Situ 0il Shale Processes

\begin{tabular}{|c|c|c|c|}
\hline Type & Developer & Description & Reference \\
\hline BX In Situ & Equity $0 i 1 \mathrm{Co}$. & $\begin{array}{l}\text { Uses steam }\left(1000^{\circ} \mathrm{F} \text {, }\right. \\
1500 \text { psig) injection } \\
\text { into injection wells } \\
\text { at leached zone of } \\
\text { Piceance Creek Basin; } \\
\text { retorted oil recovered } \\
\text { at production wells }\end{array}$ & $\begin{array}{l}\text { Dougan } 1979 \\
\text { Dougan } 1981\end{array}$ \\
\hline Geokinetics & Lofreco process & Vernal, Utan & $\begin{array}{l}\text { Chemical Engr. } \\
\text { Jan 24, } 1983\end{array}$ \\
\hline In Situ & & $\begin{array}{l}\text { Igniting oil shale } \\
\text { retorts }\end{array}$ & Gumerinan 1979 \\
\hline In Situ & & $\begin{array}{l}\text { Green River Formation, } \\
\text { Wyoming }\end{array}$ & Goldstein 1979 \\
\hline $\begin{array}{l}\text { DOW } \\
\text { (fracturing, } \\
\text { combustion, } \\
\text { gas production) }\end{array}$ & DOW Chemical Co. & $\begin{array}{l}\text { Michigan Antrim } \\
\text { shale, propane } \\
\text { ignition, gas } \\
\text { production. }\end{array}$ & $\begin{array}{l}\text { MCNamara } 1979 \\
\text { Peil } 1980 \\
\text { Young } 1986 \\
\text { Young } 1980\end{array}$ \\
\hline General & & $\begin{array}{l}\text { Economic study for } \\
\text { nypothetical } 64,000 \\
\text { bpd facility on Green } \\
\text { River shale }\end{array}$ & Jee 1977 \\
\hline $\begin{array}{l}\text { Fragmentation } \\
\text { horiz. in situ }\end{array}$ & $\begin{array}{l}\text { Eastern oil shale } \\
\text { Research Corp. }\end{array}$ & $\begin{array}{l}\text { Fragmentation of } \\
\text { eastern shale }\end{array}$ & Britton 1987 \\
\hline$:$ & & $\begin{array}{l}\text { Progress report, } \\
\text { eastern shale }\end{array}$ & Carr 1987 \\
\hline General & & Survey of technologies & Cna 1982 \\
\hline \multirow[t]{2}{*}{ General } & Talley Energy & $\begin{array}{l}\text { Research and } \\
\text { development }\end{array}$ & Jensen 1979 \\
\hline & & $\begin{array}{l}\text { Foam fracturing, } \\
\text { Devonian shale }\end{array}$ & Komar 1980 \\
\hline $\begin{array}{l}\text { Radio } \\
\text { Frequency }\end{array}$ & Bechtel & Cost estimate & $\begin{array}{l}\text { Becntel Corp. } 1986 \\
\text { Gould } 1984 \\
\text { Mallon } 1981\end{array}$ \\
\hline $\begin{array}{l}\text { Radio } \\
\text { Frequency }\end{array}$ & & Laboratory tests & Snow 1982 \\
\hline
\end{tabular}


Table 25. Modified In Situ Oil Shale Processes

\begin{tabular}{llll}
\hline Type & Developer & Description & Reference \\
\hline Occidental & Rio Blanco Project & Lieber 1980 \\
Occidental & $\begin{array}{l}\text { Occidental } \\
\text { Research Corp. }\end{array}$ & General discussion & Lumpkin 1981 \\
$\begin{array}{l}\text { Vertical } \\
\text { Modifled In SIlu }\end{array}$ & Cost analysis & Lewis 1982 \\
General & $\begin{array}{l}\text { Igniting in situ } \\
\text { retorts }\end{array}$ & Gumerman 1979 \\
General & Retort abandonment & Fox 1979 \\
\hline
\end{tabular}




\section{BIBLIOGRAPHY FOR PROCESS TECHNOLOGY}

Addington, R. R., J. B. Damukaitis, and D. A. Wilmot. "Progress Report on the Development of Triad Research Inc.'s H-E Process," 1984, Eastern 0il Shale Symposium Proceedings, University of Kentucky, Institute for Mining and Minerals Research, Lexington, KY, IMMR84/124, 1985.

Addington, R., J. Damukaitis, A. Gelbein, and M. Greene. "Liquid-Phase Hydroretorting of Low Grade 0il Shales," presented at AIChE annual meeting, San Francisco, CA, November 25, 1984, CUNF841121,1985 .

Anmed, M. M., and D. H. Archer. "Processing of Eastern 0il Shale for Liquid and Gaseous Fuels," 1981 Eastern 0il Shale Symposium Proceedings, University of Kentucky, Institute for Mining and ininerals Research, Lexington, KY, IMMR82/066, 1982.

Alabama University. "Regional Resource Assessment and Feasibility Analysis of Fossil Energy Recovery from Chattanooga (Devonian) 0il Shale in Alabama and Adjacent States," Phase II Investigation, Alabama University School of Mines and Energy Development, DOE report DOE/R4/10200-T2, August 1982.

Atwood, M. T., and S. W. Tyson. "0il Shale Retorting-Measuring Process Yields," 17th 0il Shale Symposium Proceedings, Colorado School of Mines, Golden, C0, 1984.

Ball, B. C., Jr. "Investigation into the Potential Economics of LargeScale Shale 0il Production," American Chemical Society Symposium Series, 163, 1981, 195-221.

Banks, C. E., R. I. Benner, L. L. Brannick, and B. C, Franciscotti. "Technical and Economic Study of an Integrated Single Pass Mining System for Open Pit Mining of Deep Oil Shale Deposits: Phase I Report," Sun 0il Company, Richardson, TX, Report to U.S. Bureau of Mines, PB250 525, 1975.

Barnes, H. H. "Status of Commercial 0il Shale Development in the United States," Energy Technology, August 12, 1985, 1263-1273.

Bartke, T. C. "U.S. Department of Energy 0il Shale Program Funded Research/Projects," 1986 Eastern 0il Shale Symposium Proceedings, Kantucky Energy Cabinet Laboratory, Lexington, KY, KECL86-158, 1987.

Bechtel Corporation. "Bechtel updates Cost Estimates for Radio Frequency Retorting," Synthetic Fuels Report, March 1986, 2-16.

Bender, J. "Comparison of Coal and Oil Shale Mining in Appalachia," 1981 Eastern 0il Shale Symposium Proceedings, Universily of Kentucky, Institute for Mining and Minerals Research, Lexington, KY, IMMR82/066, 1982. 
Berry, K. L. "Combined Retorting Techniques for vil Shale," Cnemical Engineering Progress, September 1979, 72-77.

Boyda, R. B. "Superior 0il/Davy McKee Circular Grate Retort," Davy McKee Corp., Cleveland, $\mathrm{OH}$, paper presented at Inst. of Gas Technology Symposium, Atlanta, GA, December 3, 1979.

Boyda, R. B. "Development of Eastern United States 0il Shales," presented at Synfuels' Second Worldwide Symposium, Brussels, Belgium, October 1982.

Braun, R. L., and A. E. Lewis. "Results of Matnematical Modeling of 0il Shale Retorting in an Aboveground, External-Combustion, Moving-Bed Retort," 18th 0il Shale Symposium Proceedinqs, Colorado School of Mines, Golden, C0, 1985.

Britton, K. "Fragmentation of Eastern 0il Shale for In Situ Recovery," 20th Annual 011 Shale Symposium, Colorado School of Mines, Golden, CO, 1987.

Carr, V. H. "Eastern Shale In Situ Project-An Update," 1986 Eastern oil Shale Symposium Proceedings, Kentucky Energy Cabinet Laboratory, Lexington, KY, KECL86-158, 1987.

Cha, C. Y., and D. Chazin. "A Survey of Current Technology for Production of 0il from 0il Shale by In Situ Retorting Processes; Their Tecnnical and Economic Readiness and Requirements for Further Development," AICnE Symposium Series, 78:216, 1982, 1-17.

Cha, C. Y. "Description of the T3 Process and its Applicability to Eastern 0il Snale," 1981 Eastern 0il Snale Symposium Proceedings, University of Kentucky, Institute for Mining and Minerals Research, Lexington, KY, IMMR82/066, 1982.

Chappe11, W. R. "Trace Elemental Release and Transportation Associated with Shale 0il Production," 12th 0il Shale Symposium Proceedings, Colorado School of Mines, Golden, CU, 1979.

Cnild, J. E., Q. N. Lee, S. S. Shin, and A. V. Sapre. "Dearsenation of Shale 0il with Low Hydrogen Consumption," Energy Progress, 6(1), March 1986, 61-65.

Colburn, T., and M. Margolis. "Retorting Kentucky 0il Snales: Yield Optimization at Moderate and Rapid Heating Rates," 16th 0il Snale Symposium Proceedings, Colorado School of Mines, Golden, Co, 1983.

Cook, J. L., and E. H. Cook. "0il Snale as a Possible Fossil Fuel Resource," Public Administration Series, Vance Bibliographies, Monticelio, IL, 1980.

Cronauer, D. C., J. Solash, D. A. Danner, and L. G. Galya. "The Importance of Hydrogen Donors in the Solvent Conversion of Eastern Shale," 1983 Eastern 0il Snale Symposium Proceedings, 
University of Kentucky, Institute for Mining Minerals Research, Lexington, KY, IMMR83/089, 1984.

Denver Research Institute. "Pollution Control Technical Manual for Tosco II 0il Shale Retorting and Underground Mining," U.S. Environmental Protection Agency, EPA-600/8-83-003, April 1983.

Dougan, E. M. "The BX In Situ 0il. Shale Project," Chemical Engineering Progress, September 1979, 81-84.

Duir, J. H., C. F. Griswold, and B. A. Christolini. "0il Shale Retorting Technology," Chemical Engineering Progress, February 1983, 45-50.

Dyni, J. R. "Distribution and Origin of Sulfur in Colorado 0il Shale," 16th Uil Snale Symposium Proceedings, Colorado School of Mines, Golden, CU, 1983.

Eital, G. L. "Update of the American Syn-Crude/Indiana Shale 0il Project," 18th 0il Shale Symposium Proceedings, Colorado School of Mines, Golden, CU, 1985.

Fischer, R. C. "Water Politics," 13th 0il Shale Symposium Proceedings, Colorado School of Mines, Golden, CO, 1980.

Forbes, F., and L. J. Colaianni. "The Mean 0il Shale Project-An Update," 1984 Eastern 0il Snale Symposium Proceedings, University of Kentucky, Institute for Mining and Minerals Research, Lexington, KY, IMMR84/124, 1985.

Frumkin, H. A., E. J. Owens, and R. B. Sutherland. "Alternative Routes for Refining Paraho Shale 0i1," Chemical Engineering Progress, September 1979, 64-71.

Fuel and Minerals Resources, Inc. "Technical and Economic Feasibility of Processed 0il Shale Beneficiation Techniques for Surface Retorting Processes," Fuel and Minerals Resources, Inc., Reston, VA, DUE report, DUE/ET/12072-T13, 1982.

Gerhart, P. C., and W. G. Holtz. "Disposal Concepts as Related to Retorted Shale Properties," 1981 Eastern Uil Shale Symposium Proceedings, University of Kentucky, Institute for Mining and Minerals Research, Lexington, KY, IMMR82/06б́, 1983.

Goldstein, K. M., and L. F. Goldstein. "Final Field Results of True In Situ 0il Shale Retorting Project in the Green River Formation of Southwestern Wyoming," Society of Petroleum Engineers, AIME, SPE8445, Technical Conference and Exhibition, Las Vegas, NV, September 23, 1979.

Gould, G. D., J. F. Bridges, R. R. Mckinsey, and G. Sresty. "In-Situ Retorting via RF Heating," 17th Uil Shale Symposium Proceedings, Colorado School of Mines, Golden, CU, 1984. 
Greaves, M. J., and D. A. Ward. "Paraho Process Technology for Eastern $0 i 1$ Shale," 1982 Eastern 0il Shale Symposium Proceedings, University of Kentucky, Institute for Mining and Minerals Research, Lexington, KY, IMMR82/075, 1983.

Greene, M., and J. Damukaitis. "Liquid-Phase Hydroretorting of Low Grade 0il Shales," Energy Progress, 5(3), September 1985, 143146.

Gregg, D. W., J. Z. Grens, R. W. Taylor, and W. R. Aiman. "Solar Retorting of Uil Shale," Lawrence Livermore Laboratory, Livermore, CA, presented at American Institute of Chemical Engineering Conference, Philadelphia, PA, June 8, 1980.

Guffey, F. D., and T. R. McLendon. "Evaluation of 0il Yield Losses During the Retorting of 0il Shale at Low Void Fractions: Part I, The Effect of Particle Size and Resource Grade," Liquid Fuels Technology, 2(4), 1984, 439-461.

Gumerman, R. J. "Igniting In Situ 0il Shale Retorts," Chemical Engineering Progress, September 1979, 85-86.

Harak A. E., W. E. Little, and C. R. Faulders. "Cyclone 0il Shale Retorting Concept," U.S. Patent No. 4,430,463, July 20, 1982, assigned to DOE report DOE/METC-84-20, Apri1 1984.

Helstand, R. N. "Estimating Solid Wastes from 0il Shale Facilities," 18th 0il Shale symposium Proceedings, Colurado schoul of Mines, Golden, C0, 1985.

Hendrickson, T. A. "Shale 0i1-Process Choices," Cnemical Engineering, May 13, 1974, 66-69.

Hilleke, A. F., and H. S. Hanna. "Evaluation of an Oil Snale Mining and Processing Operation in Alabama," 1981 Eastern 0il Shale Symposium Proceedings, University of Kentucky, Institute for Mining and Minerals Research, Lexington, KY, IMMR82/066, 1982.

Hopkins, W. N., R. P. Upadhyay, J. B. Bills, and C. R. Sandberg, III. "A Technical and Economic Study of Candidate Underground Mining System for Deep, Thick 0il Shale Deposits," Quarterly of the Colorado School of Mines, 71(4), October 1976, 199-234.

Humphrey, J. P., and J. B. Damukaibus. "Commercialization of Eastern 0il Shale," 1982 Eastern 011 Shale Sýmposium Proceedings, University of Kentucky, Institute for Mining and Minerals Research, Lexington, KY, IMMR82/075, 1983.

Illinois State Geological Survey. "Illinois Geological Survey Begins Study of Co-Pyrolysis of Coal and Oil Shale," Pace Synthetic Fuels Report, 23(1), March 1986, 2-4. 
Ivo, 0. C., J. Rezende, and E. M. Piper. "Applicability of the Petrosix Process to Kentucky 0il Shale," 1982 Eastern Uil Shale Symposium Proceedings, University of Kentucky, Institute for Mining and Minerals Research, Lexington, KY, IMMR82/075, 1983.

Janka, J. C., and R. C. Rex, Jr. "Application of the HYTORT Process to 0il Shales Throughout the World," Energy Progress, 5(4), December 1985, 203-209.

Jee, C. K., J. 0. White, and S. K. Bhatia. "A Study of True In Situ 0il Shale Technology," Booz-Allen Research, Inc., Bethesda, MD, May 1977, DOE report FE-2343-12.

Jensen, H. B. "Oil Shale In Situ Research and Development," Talley Energy Systems, Inc., Scottsdale, AZ, DOE report DOE/LC/01791-T1, 1979.

Jones, B. B., and D. B. Jones. "Senca Sees $50 \%$ cost Savings in Uil Shale Plants," Pace Synthetic Fuels Report, 23(1), March 1986, 219.

Jones, J. E., S. S. Farthing, and T. Robl. "Kentucky's Syntnetic Fuels Program and Uil Shale Development Potential," presented at Synfuel's Second Worldwide Symposium, Brussels, Belgium, October 1982.

Ketron, Inc. "Working on Candidate Mining Sites for Surface Mining of Western 0il Shales," Ketron, Inr.,, Wayne, PA, DOE report DOE/PC/42204-T1, 1981.

Komar, C. A., A. B. Yost, and A. R. Sinclair. "Foam Fracturing the Devonian Shale," World 0i 1, 191(1), July 1980, 119-134.

Kruspe, R. R., T. L. Robl, and J. A. ODley. "The Distribution and Properties of Soils in Montgonery County Potentially Impacted by Dil Shale Mining," 1983 Eastern Uil Shale Symposium Proceedings, University of Kentucky, Institute for Mining and ilinerals Research, Lexington, KY, IMMR83/089, 1984.

Kuuskraa, U. A., E. C. Hamnershaimb, J. S. Broz, and E. G. Higgins. "Market Analysis of Shale 0il Co-Products," 14th 0il Shale Symposium Proceedings, Colorado School of Mines, Golden, Co, 1981.

Lamont, W. F., K. Theodorou, R. C. Rex, Jr. "BeneficiationHydroretort Processing of U.S. Oil Shales," 1986 Eastern Oil Shale Symposium Proceedings, Kentucky Energy Cabinet Laboratory, KECL85-158, 1987.

Laramie Energy Technology Center. "A Bibliography of Publications Dealing with Dil Shale and Shale 0 il from U.S. Bureau of Mines, 1917-1974, The ERDA Laranie Energy Research Center, 1975-19/6, and the DUE Laramie Energy Technology Center, 1977-1979," DOE report LETC/RI-80/3, February 1980. 
Lau, F. S., D. M. Rue, D. V. Punwani, and R. C. Rex, Jr. "Gasification Characteristics of Eastern 0il Shale," 1986 Eastern 0il Shale Symposium Proceedings, Kentucky Energy Cabinet Laboratory, KECL86-158, 1987.

Leon, H. I., and J. H. Gary, eds. "Comparative Analysis of Nine Selected 0il Shale Properties," 13th 0il Shale Symposium Proceedings, Colorado School of Mines, Golden, C0, 1980.

Lewis, A. E. "0il Shale: A Framework for Development," 13th 0il Snale Symposium Proceedings, Colorado School of Mines, Golden, CO, 1980.

Lewis, A. E., R. L. Braun, and J. C. Diaz. "Uil Shale Retorting Processes: A Technical Overview," 17th Oil Shale Symposium Proceedings, Colorado School of Mines, Golden, CU, 1984.

Lewis, A. G., V. P. Anderson, R. D. Metz, L. M. English, and B. S. Resnick. "Oil-Shale-Mining Cost Analysis: Vol. II. Vertical Modified In-Situ Retorting Process," Ketron, Inc., Wayne, PA, February 1982, DOE report DOE/ET/12532-T6.

Lieber, R. M. "What's Next for Shale Development?" 17th 0il Shale Symposium Proceedings, Colorado School of Mines, Golden, CO, 1984.

Lleber, R. M., and T. N. Veziroglu, eds. "Rio Blanco Project," Alternative Energy Sources, Vol. 6 of Hydrocarbon Technology, Washington, DC: Hemisphere Publishing Corp., 1980.

Lind, C. G., W. J. Mitsch, R. W. Bosserman, and J. M. Klopatech, eds. "Net Energy Analysis Including Environmental Cost of $0 i 1$ Shale Development in Kentucky," International Symposium on Energy and Ecological Modeling, Louisville, KY, April 20, 1981, published as "Energy and Ecological Modeling," Amsterdam, Netherlands: El sevier Scientific Publishing Co., 1981.

Lindquist, E. D., and G. D. Ano. "A Comparison of Various Aspects of Mining 0il Shale in the Western and Eastern United States," 1981 Eastern 0il Shale Symposium Proceedings, Kentucky Institute of Mining and Minerals Research, Lexington, KY, IMMR82/066, 1982.

Lindstedt, K. D., E. R. Bennett, and R. E. Poul'son. "Study Evaluates Treatinents for 0il-Snale Retort Water," Industrial Wastes, September/October 1978, 28-33.

Lloyd, G. A. "The Means 011 Snale Project," 1983 Eastern 0il Snale Symposium Proceedings, Kentucky Institute for Mining and Minerals Research, IMMR83/089, 1984.

Lumpkin, R. E., and R. F. Meyer, eds. "Modified In Situ 0il Snale Retorting," Long-term Energy Resources, Vol. I, Occidential Research Corp., Irvine, CA, published Boston, MA: Pitman, 1981. 
Mallon, R. G. "Economics of Shale $0 i 1$ Production by Radio Frequency Heating," 14th 0il Shale Symposium Proceedings, Colorado School of Mines, Golden, Co, 1981.

Mavis, J. D., and R. M. Rosain. "Water Management in the Uil Shale Industry," Chemical Engineering Progress, June 1982, 61-69.

McNamara, P. H., and J. P. Humphrey. "Hydrocarbons from Eastern 0il Shale," Chemical Engineering Process, September 1979, 37-91.

Miller, G. A., J. R. Dyni, and D. R. Dietz. "A Brief Comparisun of Some Technological and Environmental Aspects of Large-Scale Surface and Underground Mining of 0il Shale, Piceance Creek Basin, Co," 17th 0il Shale Symposium Proceedings, Colorado School of Mines, Golden, CO, 1984.

Mitchell, J. C. "Kentucky's 0il Shale Pilot Plant Program," 1982 Eastern 0il Shale Symposium Proceedings, University of Kentucky, Institute for Mining and Minerals Research, IMMR82/075, 1983.

Morgantown Energy Technology Center. "Feasibility of Establishing and Operating a Generic 0il Shale Test Facility," DUE/METC-86-0646 (DE86006591), 1986.

Moudgil, B. M. "0il Shale Beneficiation for Above Ground Retorting," University of Florida, Gainesville, FL, Mining Engineering, 34, September 1982, 1336-1338.

Parkinson, G. "New Ways to Process 0il Shale," Chemical Engineering, February 22, 1982, 37-43.

Parkinson, W. J., T. T. Phillips, and J. W. Barnes. "Economic Comparison of Five Process Concepts for Using Eastern 0il Shale," 187th National Meeting of the American Chemical Society, St. Louis, M0, April 8, 1984.

Pease, L. R. "Tosco Technology Applied to Eastern U.S. Oil Shales," 1981 Eastern 0il Shale Symposium Proceedings, University of Kentucky, Institute of Mining and Minerals Research, Lexington, KY, IMMR82/066, 1982.

Pei1, C. A., and G. A. Cochran. "Energy from True In Situ Processing of Antrim Shale: Preparation of a Cavity by Chemical Underreaming," DOW Chemical Co., Midland, MI, April 1980, DOE report FE-2346-43.

Persoff, P., and J. P. Fox. "Control Strategies for Abandoned In Situ 0il Snale Retorts," 12th 0il Shale Symposium Proceedings, Colorado School of Mines, Golden, CU, 1979.

Pforzheimer, H. "Paraho - New Prospects for 0il Shale," Chemical Engineering Progress, 70(9), September 1974, 62-55. 
Punwani, D. V., F. S. Lau, M. J. Roberts, and W. C. S. Hu. "Status of Current Research for Hydroretorting of Eastern 0il Shale," 19th 0il Snale Symposium Proceedings, Colorado School of Mines, Golden, CO, 1986.

Rao, R. "HTGR-SC/C Application Study Report: Direct Steam Retorting of 0il Shale," G. A. Technologies, Inc., San Diego, CA, report no. GA-A-17112, July 1983.

Raymond, H. D., and M. H. Weineche. "An Update - Cliffs Engineering, Allis-Chalmers Indiana 0il Shale Project," 1986 Eastern 0il Shale Symposium Proceedings, Kentucky Energy Cabinet Laboratory, KECL 86-158, 1987.

Reeves, A. A., and J. B. Juries, Jr. "Paraho's Retort Technology tor Eastern 0il Shale," 1981 Eastern 0il Shale Symposium Proceedings, University of Kentucky, Institute of Mining and Minerals Research, Lexington, KY, IMMR82/066, 1982.

Reeves, P. C., J. H. Absil, and R. A. Meyers, eds. "0il Shale PreBeneficiation," Handbook of Synfuels Technology, New York: McGraw-Hi11, 1984.

Resnick, B. S., L. M. English, R. D. Metz, and A. G. Lewis. "0il Shale Mining Cost Analysis: Volume $I$ - Surface Retorting Process," Ketron, Inc., Wayne, PA, January 1981, D0E report DOE/FE/8915(13)-1.

Rex, R. C., and T. M. Knowlton. "Cold Flow Model Testing of the Hytort Process Retort Design," 17th 0il Shale Symposium Proceedings, Colorado School of Mines, Golderi, CU, 1984.

Roeck, D. "Combustion of Uil Shale in Fluidized-Bed Combustors: An Overview," GCA Technology Div., Bedford, MA, Report no. PB-82249889, May 1982; also published as EPA-600/7-82-045.

Rosain, R. M., and J. D. Mavis. "Water Reuse in Steam Generation Systems for 0il Shale Plants," 14th 0il Shale Symposium Proceedings, Colorado School of Mines, Golden, CO, 1981.

Rube 1, A. M., and T. T. Coburn. "Influence of Retorting Parameters on Uil Yield from Sunbury and Onio Shales from Northeastern Kentucky," 1981 Eastern Oil Shale Symposium Proceedings, University of Kentucky, Institute for Mining and Minerals Research, Lexington, KY, IMRR82/066, 1982.

Rube1, A. M., and E. Davis. "Pressurized Steam Retorting of Kentucky Uil Shales: An Investigation of the Role of Steam in Uil Yield Ennancement," 1986 Eastern 0il Shale Symposium Proceedings, Kentucky Energy Cabinet Laboratory, Lexington, KY, KECL 86-158, 1987.

Rube1, A. M., D. W. Koppenaal, D. N. Taulbee, and T. L. Robl. "Chemical Aspects of Eastern 0il Shale Returting: Analysis of a 
Core," 16th 0il Shale Symposium Proceedings, Colorado School of Mines, Golden, C0, 1983.

Schora, F. C., J. C. Janka, P. A. Lynch, and H. Feldkirchner. "Progress in Commercialization of the HYTORT Process," 1982 Eastern 0il Shale Symposium Proceedings, University of Kentucky, Kentucky Institute for Mining and Minerals Research, IMMR82/075, 1983.

Sieg, R. P., and B. G. Spars. "Snale Retorting with Supplemental Combustion Fue1," U.S. Patent No 4,293,401, assigned to Chevron Research Co., February 21, 1980.

Sladek, T. A., P. L. Poulton, W. E. Davis, and P. A. Robinson. "A Technology Assessment of Uil Snale Development," 13th Oil Shale Symposium Proceedings, Colorado School of Mines, Golden, Co, 1980.

Slawson, G. C., and T. F. Yen. "Compendium Reports on vil Shale Technology," General Electric Co., Santa Barbara, CA, EPA report EPA/600/7-79/039, January 1979.

Snow, R. H., J. J. Kristansky, and G. C. Sresty. "The IITRI RF Process Laboratory and Field Results on 0il-Shale and Tar Sands," Energy Technology, 9, June 1982, 565-577.

Stauffer, H. C. "0il Shale, Tar Sands, and Related Materials," American Chemical Society Symposium Series No. 163, American Chemical Society, Washington, DC, 1981.

Studebaker, I. G. "Mining Strategy Effects on 0il Shale Profitability," 18th 0il Shale Symposium Proceedings, Wirorado School of Mines, Golden, C0, 1985.

Suntech, Inc. "Technical and Cost Evaluation of Candidate Large Scale Open Pit 0il Shale Mining Methods in Colorado," Vol. II, parts 1 and 2, "Technical and Economic Study of an Integrated Single Pass Mining System for Upen Pit Mining of Deep 0il Shale Deposits," prepared for Bureau of ilines, PB-274-520, Juty 1976.

Superior Uil Co. "Pacific Project, Garfield County, Colorado, Phase I. Final Technical Report," Superior 0il Co., Englewood, CO, DUE report D0E/SF/10852-2139, January 1983.

Tarman, P. B. "IGT Free Fall Retorting Process," U.S. Patent 4578176, issued March 25, 1986, Institute of lias Technology, Cnicayó, IL.

Taylor, R. B. "0il Shale Commercialization: The Risks and the Potential," Chemical Engineering, September 7, 1981, 63-71.

Thumann, A., ed. "Assessment of 0il Shale Tecnnology," Atlanta, GA: The Fairmont Press, Inc., 1981. 
TRW Energy Engineering Division. "Conceptual Design of Production Systems for NOSR 1. Naval $0 i 1$ Shale Reserves Management Support and Systems Engineering Project," TRW Energy Engineering Div., McLean, VA, DOE report DUE/RA/32012-T11, October 1980.

Urban, P., L. Hi ifman, and R. W. Johnson. "Process for Recovery of Hydrocarbons from 0il Shale," U.S. Patent No. 4,438,816, assigned to UOP, InC., March 27, 1984.

Vyas, Kirit C. "Syncrude from Easter 0il Shale," 14th 0il Shale Symposium Proceedings, Colorado School of Mines, Golden, C0, 1981.

Vyas, K. C.. G. D. Ano, and T. L. Robl. "Synthetic Fuels from Eastern Uil Shale. ; Flnal Repurl (Pdralu, HYTORT)," University of Kentucky, Institute for Mining and Minerals Research, Lexington, KY. DOE report DOE/R4/10185-T1, January 1981.

Young, D. C. "An Investigation of the Feasibility of Recovering Energy from Antrim 0il Shale by an In Situ Process," DOW Chemical Company, Midland, MI, DOE report FE-2346-94, September 1986.

Young, D. C. "Energy from In Situ Processing of Antrim 0il Shale," DOW Chemical Co., Midland, MI, Quarterly Technical Progress Report for April-June 1980, DOE report FE-2346-72, July 1980.

Young, M. B., and J. B. Dicks. "The Use of Low-Btu Product Gases in 0il Shale Retorting Technical Economics, Synfuels and Coal Energy Symposium," ASME Winter Annual Meeting, Boston, MA, November 13, 1983 (1984). 


\section{RESOURCE CONSUMPTIUN}

\section{0il Shale Resource Recovery}

Open pit mining followed by surface processing usually produces the greatest recovery of oil from oil shale. However, some oil shale resources are too deep, seams too thin, or the topography is such that open pit mining is not economically feasible. Open pit mining can recover essentially 100\% of the resource, and underground room-andpillar mining can recover 60\% (Lindquist 1982). Recovery may be only 20-30\% of the resource if the deposit is thick and mined underground (Miller 1984).

Ketron, Inc. (1981), under contract to the DOE, reviewed candidate open pit oil shale mining sites in colorado, Wyoining, and Utah. A 15 gpt cut-off grade and less than 600 feet of overburden were recommended when investigating suitable sites. Seam tnickness, overburden, geological features, surface relief, and disposal area availability were also considered.

Lewis (1980) concluded that a very substantial part of the Piceance Creek Basin is suitable for open pit mining if the scale of operation is large enough, with recovery of essentially all of the resource. He also concluded that the Mahogany layer in the southern part of the Piceance Creek Basin and in eastern Utan is not suitable for open pit mining because of the nigh ratio of waste to ore and that it should be mined by the room-and-pillar underground method.

Several papers reviewed resource recovery in the eastern U.S. Bender (1980) states that surface mineable reserves are those with an in-place strip ratio less than 2.5 to 1.0 (tons of waste rock to tons of oil shale). These deposits include the oil shale outcroppings of the Knobs region in Kentucky and outcroppings in south-central onio. Hilleke (1982) reviewed open pit mining of Chattanooga shale in Madison County, Alabama, where the overburden ranges from $0-130$ feet. Lindquist (1982) suggested 100 feet as the economic cutoff point for stripping overburden for open pit mines in the eastern U.S., which corresponds roughly to a maximum stripping ratio of 2.5 to 1.0. Underground room-and-pillar mining was recommended for overburden depths between 100 and 400 feet. Lindquist (1982) concluded that western oil shale can be economically strip-mined witn an overburden up to 400 feet because western shales are thicker and have a higher grade (Fischer assay) than eastern shales. Kruspe (1984) reviewed locations suitable for strip mining in Montgomery County, Kentucky.

Resource recovery from in situ retorting is less than that for open pit or underground mining followed by surface processing. Britton (1987) reports 50\% recovery of oil in place based on Fischer assay for in situ retorts. This $50 \%$ recovery also considers only the shale retorted within the cavity or bed section fractured and does not include unretorted shale outside the cavity. The reason for the lower oil yield is the failure to obtain a uniform retorting front velocity 
within the rubble bed and because of edge effects created during rubblizing of the retort bed.

The DOE (METC 1986) generalized that eastern shale reserves are best recovered by open pit mining and western reserves are best recovered by underground room-and-pillar mining. Their estimates for recoverable resources are as follows:

\begin{tabular}{lcc}
\hline & $\begin{array}{c}\text { Area (Square Miles) } \\
\text { Surface Mined }\end{array}$ & $\begin{array}{c}\text { Recoverable } \\
\text { Resources, billion } \\
\text { Darrels oil }\end{array}$ \\
\hline State & 300 & 1.5 \\
Alabama & 600 & 20 \\
Kentiana & 2650 & 95 \\
Michigan & 160 & 2.5 \\
Onio & 980 & 70 \\
Tennessee & 1540 & 22 \\
Kansas & not stated, 75\% & 1.6 \\
& recovery estimate & 212.6 \\
Total & &
\end{tabular}

If the eastern shales are hydroretorted, recoverable $0 i 1$ could potentially be doubled. The DOE estimate for Green River Formation in place, shale grade $10 \mathrm{gpt}$ or greater, is $2050^{\circ}$ billion barrels. Assuming $60 \%$ recovery by underground room-and-plllar mining, the recoverable resource is 1230 billion barrels. In-place snale oll estimates are also given for Nevada, Montana, and Alaska. These DOE estimates do not include the equivalent barrels per day energy expenditure required to conduct mining and processing activities. Also, much of the eastern oll shale cannot be economically surface mined because it is too deep.

The Dibliography for $0 i 1$ Shale Resource Recovery is incorporated with the bibliography for process technology, presented in the previous section.

\section{Loss of Resource}

Loss of resource is defined as oil shale unavailable for recovery because of activities associated with development. For example, roughly $60 \%$ of an oil shale resource may be recoverable by room-andpillar underground mining; the remaining $40 \%$ is a loss of resource. Retorted oil shale typically occupies $25 \%$ more volume than the original in-place oil shale because of voids created during extraction and processing. This retorted oil shale must be disposed of somewhere. If placed on top of unmined areas, these areas may be rendered unsuitable for development and, therefore, would be a loss of resource. 
Loss of resource al so includes oil shale made unavailable due to construction of evaporation ponds, roads and buildings, and development of a social infrastructure (numan support services).

\section{Hater Consumption}

Generally, mining requires very little water compared with surface retorting. The major water requirement for mining is for dust suppression. Surface retorting generally requires more water than in situ retorting or modified in situ retorting for stabilization of spent shale, steam, and cooling water. Water is also required for human support services.

Nevens et al. (1979) calculated water balances for four model shale oil plants: in western colorado. The results are summarized in Table 26, which shows a net production of water for modified in situ processes because of infiltration of groundwater into the retort cavity. Conventional mining and surface retorting resulted in a net consumption of water. Nevens' water balances do not include urban potable water requirements.

Britton (1987) reports that groundwater infiltration is a serious problem during in situ processing of eastern oil shale, even more so than in the arid west. In situ processing in the east is expected to result in a net production of water. 
Table 26. Projected Water Balance at Four Model Shale Oil Plants (Nevens et al. 1979)

Water Flows in Barrels Water/Barrels Product 0il

\begin{tabular}{|c|c|c|c|c|}
\hline Water Required & Paraho ${ }^{\mathrm{a}}$ & Tosco $i I^{b}$ & $M I S^{C}$ & MIS \& Lurgi \\
\hline $\begin{array}{l}\text { Cooling tower makeup } \\
\text { Boiler feedwater makeup } \\
\text { Dust control } \\
\text { Spent snale disposal } \\
\text { Revegetation }\end{array}$ & $\begin{array}{r}0.9 \\
<0.1 \\
0.1 \\
0.4 \\
0.2 \\
\end{array}$ & $\begin{array}{l}1.5 \\
0.9 \\
0.8 \\
1.3 \\
0.2 \\
\end{array}$ & $\begin{array}{l}1.3 \\
1.0 \\
0.1 \\
0.1 \\
0.3 \\
\end{array}$ & $\begin{array}{l}1.0 \\
0.7 \\
0.1 \\
2.3 \\
0 \\
\end{array}$ \\
\hline Total & 1.6 & 4.7 & 2.8 & 4.1 \\
\hline \multicolumn{5}{|l|}{ Water Produced } \\
\hline $\begin{array}{l}\text { Cooling tower } \\
\text { Boiler blowdown } \\
\text { Retort condensate } \\
\text { Gas condensate } \\
\text { Mine drainage water }\end{array}$ & $\begin{array}{r}0.4 \\
<0.1 \\
<0.1 \\
0.2 \\
-\end{array}$ & $\begin{array}{r}0.5 \\
0.1 \\
0.3 \\
<0.1 \\
-\end{array}$ & $\begin{array}{l}0.3 \\
- \\
0.5 \\
0.8 \\
4.8 \\
\end{array}$ & $\begin{array}{l}0.2 \\
- \\
0.3 \\
0.6 \\
3.2 \\
\end{array}$ \\
\hline Total & 0.6 & 0.9 & 6.4 & 4.3 \\
\hline $\begin{array}{l}\text { Net water produced } \\
\text { (consumed) }\end{array}$ & $(0.1)$ & $(3.8)$ & 3.6 & 0.2 \\
\hline
\end{tabular}

anvil Points, 99,170 barrels per stream day (bpsd) crude oil

${ }^{b}$ Colony Development site, includes refinery, 47,000 bpsd syncrúde, spent shale molsturized to $14 \%$, includes venturi scrubbers, yield $100 \%$ of Fischer Assay of $35 \mathrm{gpt}$

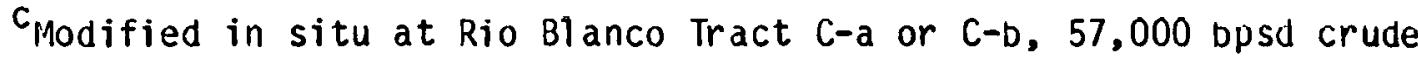
oil

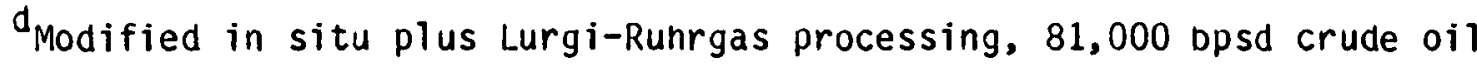




\section{BIBLIUGRAPHY FOR HATER CONSUMPTION}

Britton, K. "Fragmentation of Eastern 0il Shale for In Situ Recovery," 20th 0il Snale Symposium Proceedings, Colorado School of Mines, Golden, C0, 1987, 67-76.

Eyring Research Institute and Sutron Corporation. "An Analysis of Water Requirements for Uil Shale Processing by Surface Retorting," DUE report number TD-27954, August 1976.

Jee, C. K., J. D. White, and S. K. Bhatia. "A Study of True In Situ Uil Shale Technology," Booz-Allen Applied Research Inc., Bethesda, MD, DOE report FE-2343-12, May 1977.

Lewis, A. E. "0il Shale: A Framework for Development," $13 \mathrm{th} 0$ il Shale Symposium Proceedings, Colorado School of Mines, Golden, $\mathrm{CO}, 1980,232-237$.

Lloyd, G. A. "The Means 0il Shale Project," 1983 Eastern 0il Shale Symposium Proceedings, University of Kentucky, Institute for Mining and Minerals Research, Lexington, KY, IMMR83/089, 1984, 11-15.

Nevens, T. P., W. J. Culbertson, Jr., J. R. Wallace, G. G. Taylor, A. P. Jovanovich, and C. H. Prien. "Predicted Costs of Environmental Controls for a Commercial 0il Shale Industry," Denver Research Institute, Denver, CO, July 1979.

The Bibliography for 0il Shale Resource Recovery is incorporated with the Bibliography for Process Technology presented in the previous section. 


\section{Data Gaps and Pesearch Meeds}

Developable Resource Definition

A systematic update of recoverable shale oil needs to be completed, taking into account available oil shale resources, retorting technology, loss of resource, water availability, land use, and energy expenditure associated with development. This information should be categorized for different locations (e.g., Green River Shale, New Albany Shale). Updated reliable estimates of in-place shale oil based on Fischer assay and on organic carbon need to be developed, taking into account overburden seam thickness, depth, topography, and groundwater strata. Some of this resource would be unavailable for development because of location within wilderness areas drid parks and other ccologically sensitive dress. The recoverable resource then needs to be defined for the different technologies on a site basis, taking into account loss of resource and that some shales with nigh carbon content are suitable for nydroretorting. Costs for development need to be estimated on a site basis. Potential by-products (e.g., low Btu gas, sulfur, sulfuric acid, uranium, alumina) need to be considered, especially when developing lower grade oil shales.

Many estimates of in-place and recoverable shale oil appear in the literature. When the estimates are examined closely, gross assumptions are made that may be inappropriate for specific sites. For example, the DOE estimate quoted in this plan was based on open pit mining of eastern shales and room-and-pillar mining of western shales (Green River Formation), when in fact both mining technologies may be used at ejther location. The typical paper provides estimates of in-place or recoverable oil shale resources with no information on how the oil yield is calculated and what allowances, if any, have been made for loss of resource. The research proposed here would not only update resource estimates but includes source information for calculating more exact estimates. This work could be easily updated as the need arises.

Define Sites, Locations, and Conditions Suitable for In Situ or Modified In Situ Development

The conditions and site locations suitable for in situ development need to be defined with special attention paid to protection of groundwater. 


\section{DISCHARGE AND EMISSIONS}

\section{Solid Hastes}

Solid wastes from shale oil plants include spent shale, raw shale rejects, overburden from mining, scrap and garbage, spent catalysts, used chemicals, and sludge. Heistand (1985) makes estimates of solid wastes in each of these categories using information from existing and former oil shale projects. Not including mining overburden, spent shale accounts for the single largest category of waste, an average $81 \%$ by weight and 120-125\% by volume of the mined shale. Spent shale is more voluminous than the original shale because of voids created during mining and crushing operations. Excluding overburden; Heistand reports 880 tons: of total solid wastes, on the average, per 1000 tons of waste mined.

Hazardous and potentially hazardous wastes (as defined by RCKA) include spent catalysts from hydrogen and hydrotreating plants, some chemicals used for gas cleanup operations, off-spec shale oil products, and some sludges from water treatment plants. The materials may be hazardous depending on whether the wastes are corrosive, fail the Environmental Protection Agency extraction procedure test for heavy metals, or are in any of the wastes designated as nazardous. Wastes for the petroleum refining industry include (1) dissolved air flotation solids, (2) slop oil emulsion solids, (3) heat exchanger bundle cleaning sludge, and (4) API separator sludge. Spent shale and raw shale are exeinpt by EPA as hazardous wastes.

Therefore, waste disposal and disposal of hazardous wastes stiould be considered when siting shale oil plants. The siting plan must consider the (1) ultimate disposal of spent shale and overburden, considering that the volume is greater than the starting material, (2) potential for contamination of groundwater and surface water from leachate, and (3) proximity to hazardous waste disposal facilities. The environmental compliance considerations for spent shale disposal make this activity a inajor environmental cost. 


\section{BIBLIOGRAPHY FOR SOLID HASTES}

Environmental Protection Agency (EPA). "Pollution Control Technical Manua 1: Lurgi Uil Snale Retorting with Open Pit Mining," EPA600/8-83-005, Cincinnati, $0 \mathrm{H}, 1983$.

EPA. "Pollution Control Technical Manual: TUSCO II 0il Shale Retorting," EPA-600/8-83-003, Cincinnati, OH, 1983.

EPA. "Environmental Perspective on the Emerging 0il Shale Industry," EPA-600/2-80-2052, Cincinnati, OH, 1980.

Heistand, R. N. "Estimating Solid Wastes from dil Shale Facilities," lotn ôl Shale Sympusiuill Pruceedings, Colorado School of Mincs, Golden, CO, 1985.

Stanwood, R. M. "The Impact of RCRA (PL 94-580) on Uil shale Development," 13th 0il Shale Symposium Proceedings, Colorado School of Mines, Golden, CU, 1980. 


\section{Mastewaters}

Wastewaters from shale oil plants include produced water from retorting, contaminated condensate if steam is used in retorting, boiler blowdown, cooling tower blowdown, sanitary wastes, surface water runoff, excess scrubber water from air pollution control, mine drainage, and in situ retort cavity water. In addition, spent shale and other solids can potentially leach materials that contaminate groundwater. The major concern is not wastewater volume but the impact of shale oil development on groundwater and surface water quality.

The environmental impact statements developed for shale oil plants in Colorado, Utan, and Wyoming show a zero or near zero discharge of wastewater. Brines and wastewaters containing toxic materials are generaliy routed to evaporation ponds. Wastewater is also used as a moisturizing agent for spent shale and for dust suppression. Brown (1987) stated that processed shale should be moisturized to $15 \%$ water. Moisturization is not required for compaction of coarse spent shale (Mercer 1982).

Shale oil plants in the eastern U.S. would be expected to discharge significant wastewater which will probably be similar to that arained from coal mines. 0il shale process water is expected to be similar to some brines produced from stripper wells in Kentucky and other eastern states. Currently, the stripper well brines are discharged to surface water during periods of high stream flow. Ashland 0il Company disposes of some oil field brines by deep well injection. Presumably, deep well injection would be used to dispose of brines resulting from shale oil processing in the eastern U.S. Mercer (1982) discusses deep well injection of shale oil brines. 


\section{BIBLIOGRAPHY FOR MASTEMATER}

Brown, A. "Hydraulic Conductivity of Lurgi Processed 0il Shale," 20th 0il Shale Symposium Proceedings, Colorado School of Mines, Golden, C0, 1987.

Brown, A., M. I. Schauer, J. W. Rowe, and W. Heley. "Water Management in Oil Shale Mining," Vols. I and II, Bureau of Mines, U.S. Department of the Interior, Grand Junction, CO, 1977.

Brown, G. 0., and D. B. McWhorter. "Aspects of Liquid and Vapor Flow in Retorted 0il Shale," 1986 Eastern 0il Shale Symposium Proceedings, Kentucky Energy Capinet Laboratory, Lexington, KY, KECL86-158, 1987.

Colorado State University. "Water Pollution Potential of Spent Uil Shale Residues," U.S. Environmental Protection Agency, EPA1430EBD 12/71, 1971.

Everett, L. G., F. E. Kelly, and E. W. Hoylman. "Groundwater Quality Monitoring Recommendations for In Situ $0 i 1$ Shale Development," U.S. Environmental Monitoring Systems Laboratory, Las Vegas, NV, EPA-60014-83-045, September 1983.

Fox, J. P., and T. E. Phillips. "Wastewater Treatment in the vil Shale Industry," Lawrence Berkeley Laboratory, Berkeley, CA, LBL11214. August 198n.

Fox, J. P., D. S. Farrier, and R. E. Poulson. "Cnemical Characterization and Analytical Considerations for an In Situ ofl Shale Process water," LETC/KI-78/7, Laramfe Energy Technology Center, Larainie, WY, $19 \% 8$.

George, M., and L. P. Jackson. "Data Base of A11 Known, Published Data on Trace Elements in 0il Shale and Its Products," Western Research Institute, Laramie, WY, DOE report DOE/FE/60177-1792, December 1984.

Harbert, H. P., W. A. Berg, and D. B. McWhorter. "Lysineter Study on the Disposal of Paraho Retorted Oil Shale," U.S. Environmental Protection Agency, Cincinnati, OH, EPA-600/7-021, 1978.

Harding, B., K. D. Linstedt, E. R. Benett, and R. E. Poulson. "Study Evaluates Treatments for 0il-Snale Retort Waters," Industrial Wastes, Septemiver/October 1978.

Hicks, R. E., R. F. Probstein, 1. Wei, D. S. Farrier, J. Lotwala, and T. E. Phillips. "Wastewater Treatment and Management at 0il Shale Plants," 13th Vil Snale Symposium Proceedings, Colorado School of Mines, Golden, CO, 1980. 
Higgins, T. E., W. F. McTernan, L. A. Sachassberger, D. J. Kocornik, and K. J. Stetzenbach. "Physical-Chemical Treatment of Select 0il Shale Retort Waters," 15th 0il Shale Symposium Proceedings, Colorado School of Mines, Golden, C0, 1982.

Hines, A. L., E. O. Pedram, S. Punnose, and R. E. Poulson. "Hot Gas Stripping of 0il Shale Retort Waters," 15th 0il Shale Symposium Proceedings, Colorado School of Mines, Golden, CU, 1982.

Kelly, K. E., and J. D. Dederick. "Characterization of 0il Shale Mine Waters, Central Piceance Basin, Colorado," U.S. Environmental Protection Agency, Cincinnati, OH, EPA-600/57-84-071, August 1984.

Klieve, J. R., G. D. Rawlins, and J. R. Hoeflein. "Assessment of 0il Shale Retort Wastewater Treatment and Control Technology - Phases $I$ and II," U.S. Environmental Protection Agency, Cincinnati, $\mathrm{OH}$, EPA-600/57-81-081, May 1981.

Kocornik, D. J., W. F. McTernan, and S. L. Williams. "Treatment of an In Situ 0il Shale Retort Water," Environmental Progress, $4(3)$,. $1985,145-150$.

Mavis, J. D., and R. M. Rosain. "Water Management in the 0il Shale Industry," Chemical Engineering Progress, 78(6), June 1982, 6169.

McGowan, L. J., and S. S. Sorini. "The Effect of Residual Carbon on Adsorption of Organic Compounds by Retorted 0il Shale," 18th 0il Shale Symposium Proceedings, Colorado School of Mines, Golden, C0, 1985.

Mercer, B. W., W. Wakamy, N. E. Bell, M. J. Mason, R. R. Spencer, C. J. English, and R. G. Riley. "Summary Report, Environmental Control Technology for Shale 0il Wastewater," Battelle Memorial Institute, Richland, WA, DUE report PNL-4457 UC9 1, 1982.

Pedram, E., A. L. Hines, R. E. Poutson, and D. 0. Cooney. "Adsorption of Organics from a True In-Situ 0il Shale Retort Water on Activated Carbon in Packed Beds," Chemical Engineering Cornmunication, 15, 1982, 291-303.

Persoff, P., and J. P. Fox. "Control Strategies for Abandoned In Situ 0il Shale Retorts," 12th Uil Shale Symposium Proceedings, Colorado School of Mines, Golden, CU, 1979.

Rinaldi, G. M., J. L. Delaney, and W. H. Hedley. "Environmental Characterization of Geokinetics In Situ 0il Shale Retorting Technology," U.S. Environmental Protection Agency, Cincinnati, OH, EPA-600/57-81-021, Apri1 1981.

Rosain, R. M., and J. D. Mavis. "Water Reuse in Steam Generation Systems for 0il Snale Plants," 14th 0il Shale Symposium Proceedings, Colorado School of ilines, Golden, C0, 1981. 
Shendrikar, A. D., and G. B. Faudel. "Distribution of Trace Metals During 0 il Shale Retorting," Environmental Science and Technology, 12(3), 1978, 332-334.

Slawson, G. C., Jr. "Groundwater Quality Monitoring of Western 0il Shale Development: Identification and Priority Ranking of Potential Pollution Sources," U.S. Environmental Protection Agency, Environmental Monitoring and Support Laboratory, Las Vegas, NV, EPA-600/7-79-025, January 1979.

Stollenwerk, K. G., and D. D. Runnells. "Leachability of Arsenic, Selenium, Molybdenum, Boron, and Fluoride from Retorted 0i 1 Shale," Proceedings of the Second Pacific Chemical Engineering Congress, VoT. II, American Institute of Chemical Engineers, New Tork, NY, $19 / 1,1023-103 U$.

U.S. Environmental Protection Agency. "Environmental Perspective on the Emerging $0 i 1$ Shale Industry," Cincinnati, OH, EPA-600/2-80$205 a$. 


\section{Air Emissions}

Atmospheric emissions include (1) gases and particulates from retorting processes, (2) gases and particulates from auxiliary combustion processes, (3) emissions associated with mining, and (4) fugitive dust. Air quality can also deteriorate because of numan activity (e.g., vehicles, power generation, support services).

Emissions from shale oil plants regulated by the Clean Air Act are particulates, sulfur species, carbon monoxide, and nitric oxide

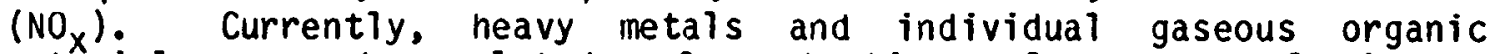
materials are not regulated. Concentrations of neavy metals in any flared off gases are now no worse than those emitted by coal combustion. Presumably, retort gases containing organic materials would be scrubbed, placed, or collected and used as a low or inedium Btu content producer gas for power generation or other end use.

When siting shale oil plants, background or baseline air quality data need to be gathered under different weather conditions at different times of the year. Regulatory agencies have accused an oil shale developer in colorado of violating particulate standards, only to discover that the particulates were emitted from vegetation and wind-blown soils unassociated with development.

In one of the many publications on air emissions and fossil fuels, Thurnau (1980) 1 ists the quantities of atmospheric emissions from mining and retorting operations normalized for a 50,000 bpd shale oil plant. 


\section{BIBLIOGRAPHY FOR AIR EMISSIONS}

Bureau of Land Management. "Final Supplemental Environmental Impact Statement for the Prototype 0il Shale Leasing Program," U.S. Department of Interior, January 1983.

Chappe 11, W. R. "Trace Element Release and Transport Associated with Shale Uil Production," 12th 0il Shale Symposium Proceedings, Colorado School of Mines, Golden, CO, 1979.

Colley, J. D. "Emissions from Synthetic Fuels Processing," Vol. II RC \#100-092, Radian Corporation, Austin, TX, June 1978.

lotter, J. t., U. J. Powell, and l. Habenicht. "Sampling and Analysis for Retort and Combustion Gases at the Paraho Shale vil Demonstration Plant," U.S. Environmental Protection Agency, Cincinnati, OH, EPA-600/7-78-065, 1978.

Domanidy, G., C. L. Sorstelie, K. H. Gala, and E. R. Bates. "Air Pollution Control for 0il Shale Applications," 1983 Eastern 0il Shale Symposium Proceedings, University of Kentucky, Institute for Mining and Minerals Research, Lexington, KY, IMMR83/089, 1983.

Dougan, P. M., and L. Dockter. "BX In Situ 0il Snale Project," 14tn 0il Shale Symposium Proceedings, Colorado School of Mines, Golden, CO, 1981.

Dunn, D. W., T. A. Bonner, and S. C. Cheng. "Oxides of Nitrogen/Ammonia Control Technology for 0i1 Shale Retort Emissions: Interim Report," U.S. Environmental Protection Agency, Cincinnati, UH, EPA-600/2-84-078, July 1984.

Dyni, J. R. "Distribution and Urigin of Sulfur in Colorado vil Snale," 16th 0il Shale Symposium Proceedings, Colorado School of Mines, Golden, Co, 1983.

Fox, J. P. "The Partitioning of Major, Minor, and Trace Elements During Simulated In-Situ 0il Shale Retorting," Ph.D. thesis, published as Lawrence Berkeley Laboratory Report LBL-9062, Berkeley, CA, 1980.

Fox, J. P., J. J. Duval1, K. K. Mason, R. D. McLaughlin, T. C. Bartke, and R. E. Poulson. "Mercury Emissions from Simulated In Situ 0il Shale Retort," lith 0il Shale Symposium Proceedings, Colorado School of Mines, Golden, C0, 1978.

Fox, J. P., R. 0. McLaughlin, J. F. Thomas, and R. E. Poulson. "The Partitioning of $\mathrm{As}, \mathrm{Cd}, \mathrm{Ca}, \mathrm{Hg}, \mathrm{Pb}$, and $\mathrm{Zn}$ During Simulated In Situ 0il Shale Retorting," 10th 0il Shale Symposium Proceedings, Colorado School of Mines, Golden, CO, 1977. 
Fruchter, J. S., C. L. Wilnerson, J. C. Evans, R. W. Sanders, and W. Abe1. "Source Characterization Studies at the Paraho Semiworks 0il Snale Retort," Battelle Memorial Institute, Richland, WA, DOE report DOE/PNL-2945, May 1979.

Green, R. "Utilities Scrub out $\mathrm{SO}_{2}, "$ Chemical Engineering, 84(11), May 25, 1977, 101-103.

Gunther, A. "Reduction of Air Emissions from Gasoline Storage Tanks," U.S. Environmental Protection Agency, Wasnington, DC, EPA-600/279-108, May 1979.

Heistand, R. N., and K. L. Richardson. "Paraho Environmental Data," Development Engineering, Inc.., Rifle, CO, DOE report DOE/EV/04708-72, Apri1 1980.

Hines, A. L., E. O. Pedram, S. Punnose, and R. E. Poulson. "Hot Gas Stripping of 0il Shale Retort Waters," 15th 0il Shale Symposium Proceedings, Colorado School of Mines, Golden, CO, 1982.

Howatson, J., J. A. Clark, and R. E. Poulson. "Inorganic Sulfur Species in Retorted 0il Shale," $17 \mathrm{th}$ 0il Shale Symposium Proceedings, Colorado School of Mines, Golden, C0, 1984.

Hughes, E. E., P. A. Buder, C. B. Fujo, R. G. Murray, and R. K. White. "0il Shale Air Pollution Control," U.S. Environmental Protection Agency; Cincinnati, OH, EPA-500/2-75-009, 1975.

Miller, G. A. "A Brief Comparison of Some Technological and Environmental Aspects of Large-Scale Surface and Underground Mining of Uil Shale, Piceance Creek Basin, CO," 17th 0il Shale Symposium Proceedings, Colorado School of Mines, Golden, Co, 1984.

Nevens, T. P., W. J. Culbertson, Jr., J. R. Wallace, G. C. Taylor, A. P. Jovanovich, and C. H. Prien. "Predicted costs of Environmental Controls for a Commercial oil Shale Industry," Denver Research Institute, Denver, C0, July 1979.

Place, B. G., F. A. Barbour, T. E. Owen, R. Hobbs, and T. F. Turner. "Desulfurization of 10-Ton Retort Off-Gas Using a Venturi Scrubber," Western Research Institute, Laramie, WY, DOE report $\mathrm{DUt} / \mathrm{t} t / 601 \% 7-1951$, May 1985.

Place, B. G., T. F. Turrer, R. Hoblss, and D. Katz. "Shale Oil Aerrosol Removal Using a Venturi Scrubber, Environmental Research on Western Research Institute's 10-Ton 0il Shale Retort," 18th 0il Snale Symposium Proceedings, Colorado School of ilines, Golden, CU, 1985.

Rinaldi, G. M., R. C. Thurnau, J. T. Lotwala, and A. Long, Jr. "Wet Scrubbing for Control of Particulate Emissions from 0il Shale Retorting," 14th Uil Shale Symposium Proceedings, Colorado School of Mines, finlden, r.n, 1981. 
Sneesley, D. C., and E. M. Leonard. "An Air Quality Strategy for 0il Shale Development," in 0il Shale - The Environmental Challenges, edited by 0il Shale Task Force, University of Colorado at Denver, published by Colorado School of Mines Press, Golden, C0, 1981.

Shendrikar, A. D., and G. B. Faudel. "Distribution of Trace Metals During Uil Shale Retorting," Environmental Science and Tecnnology, 12(332), 1978, 332-334.

Thurnau, R. "Environmental Prospective on the Emerging 0il Shale Industry: Section 3, Atmospheric Impacts," U.S. Environmental Protection Agency, Cincinnati, OH, EPA-600/2-80-205a, 1980, 4162.

Vàn Zänten, K. U., G. R. Chiaramonte, and E. R. Bates. "Control of" Sulfur Emissions from 0il Shale Retorting Using Spent Shale Absorption, Pilot Plant Testing," 19th Uil Shale Symposium Proceedings, Colorado School of Mines, Golden, CU, 1986. 
PHASE 4: IMPACTS OF OIL SHALE DEVELOPMENT 


\section{INTRODUCTION}

To successfully develop the U.S.'s oil shale resources, economical, ecological, sociological, and technological considerations need to be addressed. The development of an oil shale industry will affect air and water quality, water supply, the health and safety of workers, land uses, topography, aquatic and terrestrial biota, noise levels, grazing and agricultural activities, recreation, aesthetic values, and the social and economic structure of outlying areas.

\section{ENVIRONMENTAL IMPACT STATEMENTS}

Environmental Impact Statements (EISs) are required for oil shale development projects and must address the following:

air quality/climatology/meterology/noise,

water quality/hydrology,

geology/topograpny/soils/sei smology,

biology/terrestrial and aquatic life; nabitats of endangered species,

socioeconomic factors/demography/land use, and

historical and archaeological features.

A list of Environmental Impact Statements pubiished by various government agencies that deal with oil shale development or study geographic areas where oil shale is potentially developable is presented in Table 27. In addition to these, the federal government has issued guidelines for developing environmental monitoring operations for synfuels projects (48 FR 46676-46685). 
Table 27. Environmental Impact Statements

\begin{tabular}{|c|c|c|}
\hline Agency & Year & Title \\
\hline U.S. Atomic Energy Commission & 1972 & $\begin{array}{l}\text { Rio Blanco Gas Stimulation } \\
\text { Project Environmental Impact } \\
\text { Statement }\end{array}$ \\
\hline BLM, Wasnington, $D C$ & 1973 & $\begin{array}{l}\text { Final Environmental Impact } \\
\text { Statement Prototype 0il Snale } \\
\text { Leasing Program Tracts } \mathrm{Ca}, \mathrm{Cb} \text {, } \\
\text { Ua, and UD }\end{array}$ \\
\hline BLM, Colorado State office & 1973 & $\begin{array}{l}\text { Hayden-Ault } 345 \mathrm{kV} \text { Transmis- } \\
\text { sion Line Colorado River } \\
\text { Storage Project }\end{array}$ \\
\hline Rural Electric Association & 1974 & $\begin{array}{l}\text { Yampa Project Environmental } \\
\text { Impact Statement (USDA-REA-ES } \\
\text { [ADM] }-74-2-D \text { (EIS for Craig } \\
\text { Power Plant) }\end{array}$ \\
\hline $\begin{array}{l}\text { Energy Research and Development } \\
\text { Administration }\end{array}$ & 1975 & $\begin{array}{l}\text { Synthetic Fuels Cominercializa- } \\
\text { tion Program Draft Environ- } \\
\text { mental Impact Statement }\end{array}$ \\
\hline BLM, Colorado State office & 1976 & $\begin{array}{lll}\text { Northwest } & \text { Colorado } & \text { Coal } \\
\text { Fnvironmental } & \text { Impact Statement }\end{array}$ \\
\hline $\begin{array}{l}\text { U.S. Forest Service } \\
\text { Region II, Denver, CU }\end{array}$ & 1976 & $\begin{array}{l}\text { Thompson Creek Land Use Plan } \\
\text { Environmental Impact Statement }\end{array}$ \\
\hline BLM, Colorado State office & 1977 & $\begin{array}{l}\text { Final Environmental Impact } \\
\text { Statement Proposed Development } \\
\text { of } 0 i l \text { Shale Resources by } \\
\text { Colony Development Operation } \\
\text { in Colorado }\end{array}$ \\
\hline $\begin{array}{l}\text { Energy Research and Development } \\
\text { Administration }\end{array}$ & 1977 & $\begin{array}{l}\text { Alternative Fuels } \\
\text { Demonstration Program Final } \\
\text { Environmental Impact Statement } \\
\text { (ERDA-1547) }\end{array}$ \\
\hline BLM, Colorado State offlce & 1979 & $\begin{array}{l}\text { Development of Coal Resourccs } \\
\text { in West Central Colorado- } \\
\text { Environmental Impact State- } \\
\text { ment (DES-78-28) }\end{array}$ \\
\hline Interstate Commerce Commission & 1979 & $\begin{array}{l}\text { Draft Environmental Impact } \\
\text { Statement Western Coal Invest- } \\
\text { ment Guidelines for Railroad } \\
\text { Rate Structure (EXPARTE \#347) }\end{array}$ \\
\hline
\end{tabular}


Table 27. Continued

\begin{tabular}{|c|c|c|}
\hline Agency & Year & Title \\
\hline BLM, Utah State Office & 1979 & $\begin{array}{l}\text { Three Corners Grazing Manage- } \\
\text { ment Environmental Impact } \\
\text { Statement }\end{array}$ \\
\hline $\begin{array}{l}\text { National Park Service } \\
\text { Denver, Co }\end{array}$ & 1979 & $\begin{array}{l}\text { Wild and Scenic River Study } \\
\text { Environmental Impact Statement } \\
\text { Green and Yampa } \\
\text { Colorado (DES } 79-48 \text { ) }\end{array}$ \\
\hline $\begin{array}{l}\text { U.S. Bureau of Mines } \\
\text { Denver, Cu }\end{array}$ & 1980 & $\begin{array}{l}\text { Horse Draw 0il Shale Research } \\
\text { Tract Draft Environmental } \\
\text { Impact Statement }\end{array}$ \\
\hline BLM, New Mexico State office & 1980 & $\begin{array}{l}\text { MAPCO's Rocky Mountain Liquid } \\
\text { Hydrocaroon Pipeline Environ- } \\
\text { mental Impact Statement }\end{array}$ \\
\hline BLM, Colorado State Office & 1980 & $\begin{array}{l}\text { Green River-Hams Fork Regiona } 1 \\
\text { Coal Environinental Impact } \\
\text { Statement Round I }\end{array}$ \\
\hline BLM, Colorado State Office & 1980 & $\begin{array}{l}\text { White River Resource Area } \\
\text { Grazing Management Program } \\
\text { Environmental Impact Statement }\end{array}$ \\
\hline BLM, Colorado State Uffice & 1980 & $\begin{array}{l}\text { Proposed Superior 0i1 Company } \\
\text { Land Exchange and 0il Snale } \\
\text { Resource Development: } \\
\text { and Final Environmental Impact } \\
\text { Statement }\end{array}$ \\
\hline BLM, Colorado State Office & 1980 & $\begin{array}{l}\text { White River Dam Project: } \\
\text { Draft and Final Environmental } \\
\text { Impact Statement }\end{array}$ \\
\hline BLM, Colorado State Uffice & 1981 & $\begin{array}{l}\text { La Sal Pipeline Company-Shale } \\
\text { Uil Pipeline } \\
\text { Impact Statement }\end{array}$ \\
\hline BLM, Rock Springs, wY & 1981 & $\begin{array}{l}\text { Draft Regional Environmental } \\
\text { Assessment-0il and Gas } \\
\text { Development Big Sandy Salt } \\
\text { Wells Resource Area, Wyoming }\end{array}$ \\
\hline BLM, Colorado State Uffice & 1981 & $\begin{array}{lll}\text { Rocky } & \text { Mountain Pipeline } \\
\text { Project Environmental Impact } \\
\text { Statement }\end{array}$ \\
\hline
\end{tabular}


Table 27. Continued

\begin{tabular}{|c|c|c|}
\hline Agency & Year & Title \\
\hline $\begin{array}{l}\text { National Forest Service } \\
\text { Region II, Denver, CO }\end{array}$ & 1981 & $\begin{array}{l}\text { Rocky Mountain Regional Plan } \\
\text { Environmental Impact Statement }\end{array}$ \\
\hline BLM, Utan State Office & 1982 & $\begin{array}{l}\text { Uintah Basin Synfuels Develop- } \\
\text { ment Draft and Final Environ- } \\
\text { mental Impact Statement }\end{array}$ \\
\hline BLM, Vernal District, Utan & 1982 & $\begin{array}{l}\text { Ashley Creek Grazing Manage- } \\
\text { ment: Draft and Final } \\
\text { Environmental Impact Statement }\end{array}$ \\
\hline BLM, Utan State Office & 1982 & $\begin{array}{l}\text { Final Environmental Impact } \\
\text { Statement of the White River } \\
\text { Dam Project }\end{array}$ \\
\hline $\begin{array}{l}\text { U.S. Dept. of Energy } \\
\text { WAPA }\end{array}$ & 1982 & $\begin{array}{l}\text { Environmental Assessment Craig } \\
\text { to Rifle } 230-345 \mathrm{kV} \text { Transmis- } \\
\text { sion Line Uprate }\end{array}$ \\
\hline $\begin{array}{l}\text { National Forest Service } \\
\text { Intermountain Region }\end{array}$ & 1982 & $\begin{array}{l}\text { Uintah National Forest-Forest } \\
\text { Plan Environinental Impact } \\
\text { Statement }\end{array}$ \\
\hline $\begin{array}{l}\text { National Forest Service } \\
\text { Region II }\end{array}$ & 1982 & $\begin{array}{l}\text { Routt National Forest Land and } \\
\text { Resource Management PIan } \\
\text { Environinental Impact Statement } \\
(02-11-92-07)\end{array}$ \\
\hline $\begin{array}{l}\text { National Forest Service } \\
\text { Grand Mesa, Uncompadre and } \\
\text { Gunnison Forest Service }\end{array}$ & 1982 & $\begin{array}{l}\text { Mount Emmons Project Environ- } \\
\text { mental Impact Statement } \\
\text { (02-04-81-03) }\end{array}$ \\
\hline $\begin{array}{l}\text { National Forest Service } \\
\text { Wasnington, } D C\end{array}$ & 1982 & $\begin{array}{l}\text { Roadless Area Review and Eval- } \\
\text { uation Environmental Impact } \\
\text { Statement }(78-04)\end{array}$ \\
\hline BLM, Craig District, Colorado & 1982 & $\begin{array}{l}\text { White River Resource Area } \\
\text { Wilderness: Draft Environ- } \\
\text { mental Impact Statement }\end{array}$ \\
\hline BLM, Colorado State Uffice & 1982 & $\begin{array}{l}\text { Supplemental Environmental Im- } \\
\text { pact Statement for the Proto- } \\
\text { type Ui Shale Leasing } \\
\text { Prograin, Tracts } C-a, C-b, U-a \text {, } \\
\text { and } U-b\end{array}$ \\
\hline
\end{tabular}


Table 27. Continued

\begin{tabular}{|c|c|c|}
\hline Agency & Year & Title \\
\hline BLM, Utan State Office & 1983 & $\begin{array}{l}\text { Final Environmental Impact } \\
\text { Statement on the Uintan Basin } \\
\text { Synfuels Development }\end{array}$ \\
\hline BLM, Grand Junction, CO & 1983 & $\begin{array}{l}\text { Final Environmental Impact } \\
\text { Statement Clear creek Shale } \\
\text { 0il Project }\end{array}$ \\
\hline$B L M$, Washington, $D C$ & 1983 & $\begin{array}{l}\text { Federal 0il Snale Management } \\
\text { Program, Environmental Impact } \\
\text { Statement }\end{array}$ \\
\hline BLM, Colorado State Office & 1983 & $\begin{array}{ll}\text { Green River-Hams Fork Coal } \\
\text { Region Round II Environmental } \\
\text { Impact Statement }\end{array}$ \\
\hline BLM, Utan State Office & 1983 & $\begin{array}{l}\text { Uintan-Southwestern Utan coal } \\
\text { Region Round I I Environmental } \\
\text { Impact Statement }\end{array}$ \\
\hline BLM, Colorado State office & 1983 & $\begin{array}{l}\text { White River Resource Area } \\
\text { Wilderness Planning Amendment } \\
\text { Environmental Impact Statement }\end{array}$ \\
\hline BLM, Rock Springs, WY & 1983 & $\begin{array}{l}\text { Draft and Final Environinental } \\
\text { Impact Statement of tne } \\
\text { Chevron Phosphate Project }\end{array}$ \\
\hline BLM, Colorado State Uffice & 1983 & $\begin{array}{l}\text { Environmental Impact } \text { Statement } \\
\text { Glenwood Springs } \\
\text { Management Plan }\end{array}$ \\
\hline BLM, Wyoming State Uffice & 1983 & $\begin{array}{l}\text { Riley Ridge (Sublette, Lincoln } \\
\text { and Sweetwater Counties, WY) } \\
\text { Natural Gas Project Environ- } \\
\text { milental Impact Statement }\end{array}$ \\
\hline $\begin{array}{l}\text { National Forest Service } \\
\text { Region II, Denver, CO }\end{array}$ & 1983 & $\begin{array}{l}\text { White River National Forest } \\
\text { l.and and Resource Management } \\
\text { Plan Environmental Impact } \\
\text { Statement (02-15-83-01) }\end{array}$ \\
\hline $\begin{array}{l}\text { Rural Electrification } \\
\text { Administration }\end{array}$ & 1983 & $\begin{array}{l}\text { Rifle to San Juan } 345 \mathrm{kV} \\
\text { Transmission Line Environ- } \\
\text { mental Impact Statement (USDA- } \\
\text { REA-WAE-EIS [ADM] } 83-1-0 \text { ) }\end{array}$ \\
\hline
\end{tabular}


Table 27. Continued

\begin{tabular}{|c|c|c|}
\hline Agency & Year & Title \\
\hline BLM, Wyoming State Office & 1983 & $\begin{array}{l}\text { Rock Springs District Wilder- } \\
\text { ness Environmental } \\
\text { Statement }\end{array}$ \\
\hline BLM, Wyoming State Uffice & 1983 & $\begin{array}{l}\text { Proposed Grazing Management } \\
\text { for the Salt Wells-Pilot Butte } \\
\text { Area Environinental Impact } \\
\text { Statement }\end{array}$ \\
\hline BLM, Wyoming State Uffice & 1983 & $\begin{array}{l}\text { Red Rim, Wyoming Petition } \\
\text { Evaluation Document Environ- } \\
\text { mental Impact Statement (USM- } \\
\text { EIS-12) }\end{array}$ \\
\hline BLM, Moab, UT & 1983 & $\begin{array}{l}\text { Grand Resource Area Resource } \\
\text { Management Plan: Draft and } \\
\text { Final Environmental Impact } \\
\text { Statement }\end{array}$ \\
\hline National & 1983 & $\begin{array}{l}\text { Proposed Grand Mesa and } \\
\text { Gunnison National Forest Land } \\
\text { and Resource Management Plan } \\
\text { Environmental Impact Statement } \\
(02-04-8205)\end{array}$ \\
\hline BLM, Colorado State Office & 1984 & $\begin{array}{l}\text { Final Mobil-Pacific Oil Shale } \\
\text { Environmental Impact Statement }\end{array}$ \\
\hline $\begin{array}{l}\text { U.S. Army Corp of Engineers } \\
\text { Sacramento, CA }\end{array}$ & 1984 & $\begin{array}{l}\text { Final Environmental Impact } \\
\text { Statement Getty and Cities } \\
\text { Services Shale Oil Projects }\end{array}$ \\
\hline BLM, Colorado State Office & 1984 & $\begin{array}{lll}\text { Piceance Basin } & \text { Resource } \\
\text { Management Plan and Environ- } \\
\text { mental Impact Statement }\end{array}$ \\
\hline BLM, Wyoming State office & 1984 & $\begin{array}{lcc}\text { Rangely } & \text { Carbon } & \text { Dioxide } \\
\text { Pipeline } & \text { Environmental } & \text { Impact } \\
\text { Statement } & & \end{array}$ \\
\hline Vernal, & 1984 & $\begin{array}{l}\text { Draft Book Cliffs Resource } \\
\text { Management Plan Environmental } \\
\text { Impact Statement }\end{array}$ \\
\hline Vernal, & 1985 & $\begin{array}{l}\text { PR Springs Combined Hydro- } \\
\text { carbon Lease Conversion Envi- } \\
\text { ronmental Impact Statement }\end{array}$ \\
\hline
\end{tabular}


Table 27. Continued

\begin{tabular}{|c|c|c|}
\hline Agency & Year & Title \\
\hline $\begin{array}{l}\text { BLM, Grand Junction, CO } \\
\vdots \\
\end{array}$ & 1985 & $\begin{array}{l}\text { Proposed Resource Management } \\
\text { Plan and Final Environmental } \\
\text { Impact Statement-Grand Junc- } \\
\text { tion Resource Area, Grand } \\
\text { Junction, CO }\end{array}$ \\
\hline BLM, Utah State Office & 1985 & $\begin{array}{l}\text { Draft Utan BLM Statewide } \\
\text { Wilderness Environmental Im- } \\
\text { pact Statement (INT no. 86-1) }\end{array}$ \\
\hline $\begin{array}{l}\text { BLM, Craig, } \\
\text { White River Resource Area }\end{array}$ & 1985 & $\begin{array}{l}\text { Environmental Impact Statement } \\
\text { Federal Prototype 0il Shale } \\
\text { Tract } C-a \text {, Offtract Lease }\end{array}$ \\
\hline BLM, Craig, CO & 1986 & $\begin{array}{l}\text { Environmental Impact Statement } \\
\text { Little Snake Resource Manage- } \\
\text { ment. Plan-Draft }\end{array}$ \\
\hline $\begin{array}{l}\text { U.S. Army Corps of Engineers } \\
\text { Sacramento, CA }\end{array}$ & 1986 & $\begin{array}{l}\text { Environmental Impact Statement } \\
\text { Proposed Phase. I I Expansion of } \\
\text { the Unical Parachute (reek } \\
\text { Shale Uil Project (Draft) }\end{array}$ \\
\hline
\end{tabular}




\begin{tabular}{|c|c|c|}
\hline Company & Year & Title \\
\hline $\begin{array}{l}\text { Gulf 0il Corporation } \\
\text { Standard 0i } 1 \text { Company of Indiana }\end{array}$ & 1974 & $\begin{array}{l}\text { Prototype 0il Shale Leasing } \\
\text { Program Federal Tract C-a, } \\
\text { Exploratory Plan }\end{array}$ \\
\hline $\begin{array}{l}\text { Gulf 0il Corporation } \\
\text { Standard 0i1 Company of Indiana }\end{array}$ & 1974 & $\begin{array}{l}\text { Prototype 0il Shale Leasing } \\
\text { Program Federal Tract C-a, } \\
\text { Preliminary Development Plan }\end{array}$ \\
\hline Rio Blanco 0il Shale Project & 1974 & $\begin{array}{l}\text { Progress Reports on Tract C-a } \\
\text { 0i1 Snale Development: Quarter } \\
1 \quad(9 / 74) \text { to Quarter } 7 \\
(7 / 76) \text {. Baseline Environ- } \\
\text { mental Data Inventory }\end{array}$ \\
\hline Rio Blanco 0il Shale Project & 1975 & $\begin{array}{l}\text { Fish and Wildiife Management } \\
\text { Plan }\end{array}$ \\
\hline Rio Blanco 0il Shale & 1975 & $\begin{array}{l}\text { Rio Blanco 0il Shale Project- } \\
\text { Detailed Development Plan }\end{array}$ \\
\hline Rio Blanco Oil Shale Project & 1976 & $\begin{array}{l}\text { Rio Blanco 0il. Shale Project-A } \\
\text { Cultural Resources Inventory } \\
\text { of Rio Blanco County, Colorado }\end{array}$ \\
\hline Rio Blanco Uil Shale Company & $\begin{array}{l}1978- \\
1984\end{array}$ & $\begin{array}{l}\text { Modular Development Phase } \\
\text { Environmental Monitoring Pro- } \\
\text { gram for Lease Tract C-a: } \\
\text { Reports dated } 2 / 78,9 / 78 \text {, } \\
3 / 79,8 / 79,3 / 80,8 / 80,3 / 81 \text {, } \\
8 / 81,4 / 82,9 / 82,4 / 83,9 / 83 \text {, } \\
4 / 84,12 / 84 .\end{array}$ \\
\hline Shate Company & 1979 & $\begin{array}{l}\text { Activities for Development of } \\
\text { a Dewatering-Reinjection } \\
\text { System at Tract C-a, Rio } \\
\text { Blanco County, Colorado }\end{array}$ \\
\hline Rio Blanco Oil Shale Company & 1981 & $\begin{array}{l}\text { Water Assessment of Rio Blanco } \\
\text { Uil Shale Project-White River } \\
\text { Rasin. Colorain }\end{array}$ \\
\hline Rio Blanco Dil Shale Company & $\begin{array}{l}1983- \\
1985\end{array}$ & $\begin{array}{l}\text { Monitoring Program and the } \\
\text { Appropriation of Springs in } \\
\text { the Vicinity of Tract C-a: } \\
\text { March, } 1983 \text { and January } 1985\end{array}$ \\
\hline
\end{tabular}




\begin{tabular}{|c|c|c|}
\hline Agency & Year. & Title \\
\hline $\begin{array}{l}\text { C-b Shale 0il Project } \\
\text { Asnland 0il, Inc. }\end{array}$ & $\begin{array}{l}1974- \\
1976\end{array}$ & $\begin{array}{l}\text { Quarterly Baseline Summary: } \\
\text { Reports Tract C-D: } 11 / 74-10 / 76\end{array}$ \\
\hline $\begin{array}{l}\text { Cathedral Bluffs Shale 0il } \\
\text { Company }\end{array}$ & $\begin{array}{l}1979- \\
1983\end{array}$ & $\begin{array}{l}\text { Cathedral Bluffs C-b oil Shale } \\
\text { Lease Annual Reports-Environ- } \\
\text { mental Analyses }\end{array}$ \\
\hline $\begin{array}{l}\text { Cathedral Bluffs Shale Uil } \\
\text { Company }\end{array}$ & 1984 & $\begin{array}{l}\text { Environmental Monitoring Plan } \\
\text { Outline. }\end{array}$ \\
\hline $\begin{array}{l}\text { Calliedidal Bluffs Shale Oil } \\
\text { Company }\end{array}$ & 1986 & $\begin{array}{l}\text { Summary of Development Activi- } \\
\text { ties, costs dild Environmental } \\
\text { Monitoring for } 1985\end{array}$ \\
\hline Project & 1977 & $\begin{array}{l}\text { White River Shale Project - } \\
\text { Detailed Development Plan } \\
\text { Federal Leases Tracts U-a and } \\
\text { U-b, and C-a, Rio Blanco } \\
\text { County, Colorado }\end{array}$ \\
\hline
\end{tabular}




\section{BIBLIOGRAPHY FOR GENERAL ENYIRONMENTAL IMPACTS}

Ashland 0il, Inc. "0il Shale Tract C-b Environmental Baseline Program Annual Summary and Trends Report, November 1974-0ctober 1975," U.S. Department of the Interior Prototype $0 i 1$ Shale Leasing Program.

Bates, E. R., and K. Jakobson. "Status of EPA's Pollution Control Guidance Document for 0il Shale," 14th 0il Shale Symposium Proceedings, Colorado Senool of Mines, Golden, C0, 1981.

Bates, E. R., J. G. Herrmann, J. F. Martin, and R. C: Thunau. "Environmental Research for Eastern 0il Shale," 1981 Eastern 0i1 Snale Symposium Proceedings, University of Kentucky, Institute for lining and Minerals Research, Lexington, KY, IMMR Report IMMR82/066, 1983.

Bates, E. R., W. W. Liberick, and J. Burckle. "0il Snale-Potential Environmental Impacts and Control Technology," presented at the AICnE Annual Meeting, Session 65.

Bureau of Land Management. "Final Environmental Impact Statement: Clear Creek Snale 0il Project," May 1983.

Bureau of Land Management. "Piceance Basin Resource Management Plan and Environmental Impact Statement," BLM, White River Resource Area, Meeker, C0, v. 1, April 1984; v. 2, April 1984; v. 3-March 1985.

Bureau of Land Management. "Oraft Environmental Statement on the Grand Junction Resource Management Plan," BLM, Grand Junction Resource Area, Grand Junction, CO, March 1985.

Bureau of Land Management. "Final Environmental Statement: Proposed Development of Vil Shale Resources by the Colony Development Operation in Colorado," v. II, Crain, C.O.

Bureau of Land Management. "Final Supplemental Environmental Impact Statement for the Prototype Uil Shale Leasing Program," BLM, White River Resource Area, Meeker, CO, January 1933.

Bureau of Land Management. "Book Cliffs Resource Management Plan/Environmental Impact Statement," BLM, Vernal District, Vernal, UT, November 1984.

Bureau of Land Management. "Oraft Environmental Impact Statement, Federal Prototype 0il Shale Tract C-a, Offtract Lease," BLM, White River Resource Area, Craig, CU, September 1985.

Bureau of Land Management. "Federal 0il Shale Management Program: Draft Environmental Impact Statement," BLM, Wasnington, DC, February 1983, BLM Report 3900 (543). 
Cathedral Bluffs Shale 0il Company. "Environmental Monitoring Plán Outline," Grand Junction, CO, March 1984, BLM Report.

Cathedral Bluffs Shale 0il Company. "Summary of Development Activities, Costs and Environmental Monitoring-1985;" Grand Junction, CO, April 1986, BLM Report.

Crawford, K. W., C. H. Prien, L. B. Baboolal, C. C. Snin, and A. A. Lee. "A Preliminary Assessment of the Environmental Impacts from Uil Shale Developments," Industrial Environmental Research Laboratory, Cincinnati, UH, EPA Report EPA-600/7-77-069, 1977.

Dadiani, J., and L. L. Meyer. "Environmental Baseline Characterization of the Naval Oil Shale Reserves in Colorado," 15tn 0il Shale Symposium Proceedings, Colorado School of Mines, Golden, Co, 1983.

DOE/Uccidental oi 1 Shale, Inc. "Environmental Assessment, DOE/ Occidental 0il Shale Inc. Cooperative Agreenent, Phase II 0il Shale Retorting," November 1979, DOE report DOE/EA-0095.

Environmental Protection Agency. "0il Shale and the Environinent," Interagency Energy-Environment Research and Development Program, EPA, Office of Research and Development, Washington DC, 1977, EPA Report EPA-600/9-77-033.

Farrier, D. S., J. E. Virgona, T. E. Phillips, and R. E. Poulson. "Environmental Research for In Situ 0il Shale Processing," 1ith 0il Shale Symposium Proceedings, Colorado School of Mines, Golden, C0, 1978.

Ferraru, P., dild P. Nazaryk. "Assessment of the Cumulative Environmental Impacts of Elleryy Development in Northwestern Colorado: Status Report," 15th 0il Snale Symposium Proceedings, Colorado School of Mines, Golden CO, 1982.

Ferraro, P., and P. Nazaryk. "Assessment of the Cumulative Environmental Impacts of Energy Developinent in Northwestern Colorado: Final Report," Colorado Department of Health in Cooperation with the U.S. EPA, Region VIII, 1983, Denver, CO.

Geokinetics, Inc. "Environmental Assessment: Geokinetics, Inc. 0il Shale Research Project, Uintan County, Utan," U.S. Department of Energy, Assistant Secretary for Fossil Energy, 1979, D0E Report DUE/LETC/EA-0114, Laramie, WY.

Gulf 011 Corporation and Standard 0il Company of Indiana. "Prototype 0il Shale Leasing Program-Colorado Tract $C$-a Preliminary Development Plan," Bureau of Land Management, Craig, CO, January 1974.

Gulf Uil Corporation and Standard 0il Company of Indiana. "Prototype 011 Shale Leasing Program-Federal Tract C-a Exploratory P1an," Bureau of Land Management, Craig, CU, May 1974. 
Haack, B., L. Istvan, R. Sampson, F. Tanis, and F. Thomson. "Environmental Monitoring Plan," U.S. Department of Energy, Environmental Research Institute of Michigan, Ann Arbor, MI, 1977, TID-27903.

Hannan, R. R. "An Environmental Assessment of the Kentucky 'Knobs' 0il Shale Region," 1982 Eastern 0i1 Shale Symposium Proceedings, University of Kentucky, Institute for Mining and Minerals Research, Lexington, KY, 1983.

Hecox, W. E. "Colorado 0il Shale: Analyzing Projected Future Levels of Development and Associated Socio-Economic and Environmental Impacts," .13tn 0il Shale Symposium Proceedings, Colorado School of Mines, Golden, CO, 1980.

Kilburn, P. D. "Environmental Implications of 0il Shale Development," Environmental Conservation, 3(2), 1976, 101-116.

Lappi, R. L., D. I. Carey, A. H. Pelofsky, E. R. Bates, and J. F. Martin. "Overview of Environmental Impacts of Large-Scale Surface Mining of Uil Shale: Piceance Basin, Colorado," 15th 0il Shale Symposium Proceedings, Colorado School of Mines, Golden, CO, 1982.

Laramie Energy Research Center. "Environmental Assessment Report: 0il Shale In Situ Processing Research Site 9 and Site 10 Rock Springs, Wyoming," U.S. Energy Research and Development Administration, Laramie Energy Research Center, Laramie, WY, 1976.

Miller, G. A., J. R. Dyni, and U. R. Deitz. "A Brief Comparison of Some Technological and Environmental Aspects of Large-Scale Surface and Underground linining of 0il Shale, Piceance Creek Basin, Colorado," 17th 0il Snale Symposium Proceedings, Colorado School of Mines, Golden, CU, 1984.

National Technical Information Service (NTIS). "Baseline Data Environmental Assessment of a Large Coal Conversion Complex," 1 , May 1975, NTIS Report FE-1508-71.

National Technical Information Service (NTIS) and U.S. Department of Commerce. "Oil Shale Mining, Processing, Uses and Environmental Impacts-Citations 1970-1976," NTIS/PS-76/0320.

Nuckols, J. R., J. M. Greer, and I. D. Moore. "Potential Environinental Impact of a Hypotheticial 200,000 Barrol/Day 0il Shale Industry in Kentucky," 1982 Eastern 0il Shale Symposium Proceedings, University of Kentucky, Institute for Mining and Minerals Research, Lexington, KY, 1983.

Uccidental 0il Shale, Inc. "U.S. Department of Interior Prototype 0il Shale Leasing Program," Craig, CU, February 1979, BLM Report. 
Peterson, E. J., E. F. Thode, P. Wagner, and P. L. Wanek. "An Integrated Environmental Control Technology Approach to 0il Shale Commercialization," Los Alamos Scientific Laboratory, Los Alamos, NM, Uctoder 1980, Los Alamos Report LA-8378.

Petersen, Kathy Kellogg, ed. 0il Shale, the Environmental Challenges II, Colorado School of Mines Press: Golden, CO, 1982.

Pfeffer,* F. M. "Pollution Problems and Research Needs for an 0il Shale Industry," EPA, Environmental Research Laboratory, Ada, 0K, 1974, EPA Report EPA-660/2-74-067.

Poulson, R. E., and H. B. Jensen. "Environmental Effects of In Situ Recovery of 0il Shale," in In Situ Recovery of 0il Shale, Penner, s. S., ed.; NSE/IIANN Keport no. 16-U01, 1975, 251-265.

Reynolds, J. P., W. N. McCartny, Jr., and L. Theodore. "Environmental and Economic Considerations in Energy Utilization," 7tn National Conference on Energy and the Environment Proceedings, Phoenix, $A L, 1980$.

Rio Blanco 0il Shale Company. "Modular Development Phase Environmental Monitoring Program-Yearly Reports," 1978-1984.

Rio Blanco 0il Snale Project. "Rio Blanco 0il Shale Project-Tract C-a Detailed Development Plan Uutline," Bureau of Land Management, Craig, CU, December 1975.

Rio Blanco 0il Snale Project. "Progress Report Number 1 on Tract C-a 0il Shale Development," Bureau of Land Management, Craig, Co, 1974-197G.

Rio Blanco 0il Snale Project. "Environmental Evaluation Procedures and Disposal Site Evaluations," Gulf 0il Corp. and Standard 0il Co. (Indiana), Denver, C0, 1975.

Routson, R. C., R. E. Wildung, and R. M. Bean. "A Review of the Environmenlal Impact of Ground Disposal of Uil Shale Wastcs;" Journal of Environmental Quality, $8(1), 1979,14-19$.

Schottler, G. R., and G. J. Leonard. "Environmental Analysis for the Bureau of Mines. Uil Shale Research Facility," 12th 0il Shale Symposium Proceedings, Colorado School of Mines, Solden, Co, 1979.

Sheesley, D. C., W. F. McTernan, J. D. Westhoff, and R. E. Poulson. "Environmental Research at the Laramie Energy Technology Center," 14th Uil Shale Symposium Proceedings, Colorado School of Mines, Golden, C0, 1981.

Shogren, R. "Industry and Environmental Comments on Kentucky's Proposed Uil Shale Regulatory Program," 1981 Eastern 0il Shale Symposium Proceedings, University of Kentucky, Institute for Mining and Minerals Research, Lexington, KY, 1982. 
Tanis, F. J., B. N. Haack, and R. B. Fergus. "Potential Environmental Problems Associated with In Situ Gasification of the Antrim Shale," Ilth 0il Snale Symposium Proceedings, Colorado School of Mines, Golden, C0, 1978.

Tolbert, V. R., G. K. Eddlemon, R. H. Ketelle, J. F. McBrayer, R. R. Mckeown, E. D. Waits, and J. W. WebD. "A Preliminary Assessment of Environmental Impacts of ODtaining 0il from Chattanooga Shale," 1981 Eastern 0il Shale Symposium Proceedings, University of Kentucky, Institute for Mining and Minerals Research, Lexington, KY, 1983.

U.S. Department of Energy. "Environmental Impact Statement, Mining, Contraction, and Operation for a Full Size Module at the Anvil Points 0il Shale Facility, Rifle, Garfield County, Colorado," DOE Report DOE/EIS-0070.

U.S. Environmental Protection Agency. "Environmental Perspective on the Emerging 0il Shale Industry," Industrial Environmental Research Laboratory, Cincinnati, OH, EPA Report EPA-600/2-205a.

U.S. Environinental Protection Agency. "A Preliminary Assessinent of Environmental Impacts froin 0il Snale Developments," EPA Report EPA-600/7-77-069, Cincinnati, $\mathrm{OH}$.

Union 0il Company. "Environmental Impact Statement for Proposed Phase II Expansion of Unical's Parachute Creek Shale Uil Project," U.S. Army Corp of Engineers, Sacramento District Office, CA, 1986.

Virgona, J. E., R. E. Poulson, and T. J. Spedding. "Summary of the Environmental Monitoring at the Rock Springs, Wyoming Site No. 9, True In Situ 0il Shale Retorting Experiment," Laramie Energy Technology Center, Laramie, WY, 1979, LETC Report LETC/RI-79/03.

Welles, J. G. "Current Environmental Issues Facing vil Shale Development," 17th 0il Shale Symposium Proceedings, Colorado School of Mines, Golden, C0, 1984. 


\section{IMPACTS OF AIR EMISSIONS}

\section{Air Quality}

0il shale wastes and emissions that affect air and water quality are of special concern. Atmospheric emissions from oil shale processing include sulfur dioxide, hydrogen sulfide, nitric oxide, and carbon monoxide. Hydrocarbons are present in combustion emissions and in product storage tank vapors. Particulate matter results from blasting, handling and disposal of raw and retorted shale, shale dust in flue gases, fuel combustion, and activities on site which generate fugitive dust (e.g., haul road traffic and diesel engine exhaust). Silica may derive from the shale, associated rocks, and fugitive dust; retorted shale may release ammonia, hydrogen sulfide, and volatile organics in off-gases during motsturiziriy and cooling (Crawford ct al. 1977).

The quantities of atmospheric emissions depend on variables such as the size of the operation, the type of mining and retorting technology used, the extent of on-site upgrading, and the degree of emissions control practiced (Crawford et al. 1977). The quality of atmospheric emissions depends largely on the emission control inethods employed and the scrutiny of operation.

\section{Control of Emissions and Impacts}

Criteria airborne pollutants from oil shale retorting are nitrogen dioxide, sulfur dioxide, carbon monoxide, non-methane nydrocarbons (NMHC), and total suspended particulates (TSP). Al though retorting may be the major air pollutant source, all phases of oil shale processing can degrade the atmosphere.

0il shale processing requires the control of fugitive dust to limit TSP generated by blasting, mining operations, road construction, excavation, and spent shale disposal. The amount of fugitive dust generated depends on the retorting process. Thurnau (1980) compiled data from five predictive oil shale open pit mining schemes to estimate the environmental impacts of TSP. He found that the estimates vary on the order of 100 magnitude between projects. The variability is due to the claim that dust emissions can be minimized $80 \%$ by wetting. Underground mining and/or retorting is preferred to open pit mining because air pollution problems are, generally, greatly diminished. However, in situ processing can be harmful to groundwater quality. Crawford et a1. (1977) estimate that true in situ retorting would produce only .01 tpd of TSP, the majority of which would result from surface venicle activities. Underground mining and modified in situ retorting produce similar amounts of TSP per ton of ore mined (Thurnau 1980) and range from .08 to 1.4 tpd for a 50,000 bpd oil shale operation.

Sulfur emissions are crucial environmental concerns for the oil shale industry. In contrast to many other air pollutants that result from oil shale retorting, sulfur emissions are neavily regulated by both the federal and state governments. Western oil shale usually 
contains less sulfur than eastern oil shale; nonetheless, large quantities of sulfur are emitted daily from an efficient oil shale operation. Retort gases contain hydrogen sulfide as the major sulfur constituent, but also typically present are sulfur dioxide, carbon disulfide, and an array of trace organic sulfur compounds.

The Clean Air Act states that the Best Available Control Technology (BACT) must be used by industries to Prevent Significant Deterioration (PSD) of the atmosphere. BACTs are reviewed by the EPA on a case-by-case basis. Sulfur emission control technology can be 95-99\% efficient; however, it is expensive, constituting the major part of the environmental costs of an oil shale facility. A review of sulfur emissions for various types of oil shale processes appears in Tabback et al. (1986).

Nitrogen oxide emissions also affect air quality. Acid deposition associated with long range transport of industrial emissions has not yet affected surface water in the West. Eastern lakes that have already experienced acidic limnological changes will continue to deteriorate from the sulfur and nitrogen emissions of oil shale processing. The amount of acid deposition is difficult to predict for various reasons (e.g., the amount of sulfur and nitrogen removed by stack treatment processes, prevailing wind directions, amount and proximity of sensitive lakes, and the amount of sulfur and nitrogen converted to acid compounds in oil shale off gases) which are unknown or, at best, indefinite. A review of the most recent advances in predicting western acid deposition appears in Fox (1985). An assessment of the vulnerability of wilderness areas in western oil shale regions to acid deposition was addressed by Turk and Adams (1983).

Air emissions from processing eastern oil shale are further complicated by the poor air dispersal patterns associated with the more numid southeast. Tolbert et al. (1981) report that temperature inversions are quite common in eastern regions (45\% of the time). 


\section{BIBLIOGRAPHY FOR AIR QUALITY}

Beak Consultants, Inc. "Air Quality Technical Report for Tract C-a Uil Shale Lease and Alternative Disposal Sites," Denver, CU.

Biezugbe, G. B. 0., B. G. Place, T. E. Owen, and F. A. Barbour. "Process Off-Gas Characterization Experiments on Block Reactor Runs 10 and 12," Western Research Institute, Laramie, WY, July 1986, D0E report in review.

Crawford, K. W., C. H. Prien, L. B. Baboolal, C. C. Snin, and A. A. Lee. "A Preliminary Assessment of the Environmental Impacts from 0il Snale Developments," EPA, Cincinnati, OH, EPA Report EPA$600 / 7-77-069,1977$.

Domanidy, D., C. L. Sonstelie, K. H. Gala, and E. R. Bates. "Air Pollution Control for Uil Shale Applications," 1983 Eastern 0il Shale Symposium Proceedings, University of Kentucky, Institute for Mining and Minerals Research, IMMR831089.

Duval1, J. J., and K. K. Mason. "Effect of Uil Shale Type and Retorting Atmosphere on the Products from Retorting 0il Shales by the Controlled State Report," Laramie Energy Technology Center, Laramie, WY, Report of Investigations-80/2, 1980.

Engineering Science, Inc. "Air Quality Assessment of the 0il Shale Development Program in the Piceance Creek Basin," McLean, VA, 1.974.

Fox, D. G. "Predicting Atmospheric Deposition for Permitting and Other Regulatory Applications," Acid Deposition Symposium-Air Pollution Control Association, Boulder, CO, 1985.

Fox, D. G., D. J. Murpny, and D. Haddow. "Air Quality, Oil Shale and Wilderness-A Workshop to Identify and Protect Air Quality Related Values of the Flat Tops," Ceneral Technical Report RM-91, U.S. Department of Agriculture, Forest Service, Rocky Mountain Forest and Range Experiment Station, Fort Collins, C0, 1982.

Guffey, F. D., F. A. Barbour, and R. E. Cummings. "Evaluation of Analytical Data for Sulfur Species in 0il Shale Retort offGases," presented at Confab 83, August 25, 1983, Saratoga, WY.

Howatson, John, H. Dewalt, D. Outka, D. Diller, M. Cain, and J. W. Smith. "Reaction of Nancolite with Sulfur Dioxide," Journal of Air Pollution Control Association, 30(11), 1980, 1229-1230.

Hughes, E. E., P. A. Buder, C. B. Fojo, R. G. Murray, and R. K. White. "Oil Shale Air Pollution Control," EPA, Cincinnati, OH, EPA Report EPA-600/2-75-009, 1975.

Jones, D. C., W. S. Clark, J. C. Lacy, W. F. Holland, and E. D. Sethness. "Monitoring Environmental Impacts of the Coal and Oil Snale Industries: Research and Development Needs," EPA, Cincinnati, OH, EPA Report EPA-600/7-77-069, 1977. 
Miller, G. A., J. R. Dyni, and D. R. Dietz. "A Brief Comparison of Some Technological and Environmental Aspects of Large-Scale Surface and Underground Mining of 0il Snale, Piceance Creek Basin, Colorado," 17th 0il Shale Symposium Proceedings, Colorado School of Mines, Golden, CO, 1984.

PEDCO Environmental, Inc. "Air Quality Impacts of 0il Shale and Related Growth in Western Colorado," National Park Service, Denver, C0, revised, 1982.

Place, B. G., F. A. Barbour, T. E. Owen, R. Hobbs, and T. F. Turner. "Desulfurization of 10-ton Retort off-Gas Using a Venturi Scrubber," Western Research Institute, Laramie, WY, May 1985, DUE/FE/60177-1951.

Place, B. G., T. F. Turner, R. Hobbs, and D. Katz. "Snale 0il Aerosol Removal Using a Venturi Scrubber Environmental Research on WRI's 10-ton 0il Shale Retort," 18th 0il Shale Symposium Proceedings, Colorado School of Mines, Golden, C0, April 1985.

Plancher, H., and L. Turrio Baldassari. "Evolution of Nitrogen Constituents from Fossil Fuels During Temperature Programmed Nitrogen Analysis," presented at Confab 86, Silver Creek, Co, July 24, 1986.

Shannon, J. D., and D. G. Streets. "Climatological Emission Control Strategies to Reduce Acid Deposition," Department of Energy, NTIS DE85018375, 1985.

Sheesley, D. C., and E. M. Leonard. "An Air Quality Strategy for 0il Shale Development," in 0il Shale-The Environinental Challenges, Petersen, Kathy Kellogg, ed.; Golden, CO: Colorado School of Mines Press, 1981.

Tabback, H., E. Bates, and R. Goldstick. "The Effect of Uil Shale Recovery Processes on Air Emissions," 19th 0il Shale Symposium Pruceedings, Colorado school of Mines, Golden, CU, 1986.

Thurnau, R. "Atmospheric Impacts," in Environmental Perspectives on the Emerging 0il Shale Industry, Bates, E. R., ed., EPA-600/2-80205a, Cincinnati, $\mathrm{OH}, 1980$.

Tolbert, V. R., G. K. Eddlemon, R. H. Ketelle, J. F. McBrayer, R. R. Mckeown, E. D. Waits, and J. W. Webb. "A Preliminary Assessment of Environinental Impacts of Obtaining Oil from Cnattanooga Shale," 1981 Eastern 0il Shale Symposium Proceedings, Kentucky Department of Energy and the University of Kentucky, Institute for Mining and Minerals Research, Lexington, KY, 1981.

Turk, J. T., and D. B. Adans. "Sensitivity to Acidification of Lakes in the Flat Top Wilderness. Area, Colorado," Water Resources Research, 1983, 19, 346-350. 
U.S. Environmental Protection Agency-Industrial Environmental Research Laboratory. "Pollution Control Document for 0il Shale," 0il Shale Working Group, EPA, Cincinnati, OH.

VanZanten, K. D., and E. R. Bates. "Control of Sulfur Emissions from Oil Snale Retorting Using Spent Shale Absorption Pilot Plant Testing," 19th 0il Shale Symposium Proceedings, Colorado School of Mines, Golden, CU, 1986.

Vinson, R. P., K. C. Cox, and F. N. Kisse11. "Metnane Encountered at the Bureau of Mines 0il Shale Shaft," 12th 0il Shale Symposium Proceedings, Colorado School of Mines, Golden, CU, 1979. 


\section{IMPACTS OF MASTEHATER \\ by Robert Donovan and Rhonda James}

\section{Nater Quality}

Hydrological impacts of oil shale processing include effects to water quality, reduction in quantities of surface and groundwater, wastewater disposal, and leaching of spent shale piles. Water is consumed for cooling, dust control, gas cleaning and process emissions control, and moisturizing retorted shale. The production of one cubic meter of processed shale may require as much as 3.7 cubic meters of water, a ratio of almost 1:4 (Crawford et al. 1977). For the oil shale industry's purpose, process waters would be reused when high quality water is not required and for moisturizing retorted shale. If the process was totally water-consumptive and if all solid and liquid wastes were contained in processed shale disposal embankments, then minimal degradation of surface water quality would result. However, the effects of erosion, runoff, and leaching of the embankment on groundwater quality are not well understood (Kilburn 1976).

Leachates that result from spent shale piles are a threat to water quality. Leachate composition is affected by the temperature and atmosphere of the retort, the mineralogy of the shale, the porous media properties of the spent shale, and the transport rates of pollutants through the spent shale (Ramirez et al. 1982; Stollenwerk et a1. 1981). The release and mobility of selected elements (e.g., boron, fluorine, molybdenum, arsenic, and selenium) are of concern due to their known toxicity to plants and animals and because they occur as soluble anions under high $\mathrm{pH}$ conditions (8-12). However, high concentrations of reduced sulfur species, principally thiosulfate, are found in retorted oil shale. Reduced species of sulfur are known to have deleterious effects on the environment, such as inhibiting germination of certain phytotaxic species and oxidizing to sulfuric acid in water which may receive the leachate. Changes in pH resulting from oxidation of reduced sulfur species will affect the leaching and mobility of other potential contaminants from waste oil shale (Stollenwerk et al. 1981). Sulfur-loving microorganisms in soil also oxidize reduced sulfur species, thereby lowering pH (Saffer et a). 1982). Further research is needed for a complete understanding of environmental impacts caused by leaching of spent shale piles.

Wastewater frum retorting oil shale contains salts, dinydrogen sulfide, ammonia, phenols, and other organic compounds (Saffer et al. 1982); it is derived primarily from water released by dehydration of oil shale minerals and from water lhat is formed as a by-product of combustion of organic matter during retorting (Hepler et a1. 1979). One suggestion is to co-dispose retorted shale and wastewater; according to a study by Jackson and Jackson (1982), no significant environmental impact would result from the co-disposal of oil shale wastewater and retorted shale. More research is needed in this area. 


\section{Surface Retorting}

0i1 shale processing produces wastewaters in two ways. Substantial amounts of water are emulsified in the nydrocarbon product and must be separated from the crude oil. After separation, this retort water is high in dissolved organic carbon, aliphatic carboxylic acids, phenols and other simple aromatics, and oil and grease (Healy et a 1. 1983). In addition to retort waters, condensates are collected from the off gases. These condensates are characterized by concentrations of ammonia and dissolved inorganic carbon (water hardness). Retort water is also enriched in trace elements ( $B, \mathrm{Fe}$, $\mathrm{Ni}, \mathrm{Cu}, \mathrm{Sn}$, and $\mathrm{Al}$ ), ammonia, chloride, and sulfate. Dissolved solids are typically in the $50,000 \mathrm{mg} / \mathrm{L}$ range (Hicks et al. 1980).

There are numerous tcsts described in the literature for estimating the amount and types of organic and inorganic species that might be leached from a solid waste disposal pile le.g., Jackson and Jackson 1980; Stollenwerk 1980; Esmaili 1983; Fox et a1. 1984; Sorini and Donovan 1986). Because of the number of open variables in designing a leaching experiment, studies generally cannot be directly compared nor can they be extrapolated to estimate actual productionscale leaching Dehavior. Some trends are evident, however. It appears that organic compounds that are more polar, more soluble, and have higher boiling points are most common in spent shale leachates (Fox et al. 1984). If the spent shale is moistened with process waters (retort water or blow down water), the amount of organic carbon in leachates greatly increases. However, the leachates are not simple dilutions of the processing waters used for moisturization but are altered compounds resulting from shale-water Interactions (Peterson et a 1. 1984). Inorganic products from leaching experiments are enriched in chlorine salts and inorganic carbon. Metal concentrations are often orders of magnitude greater than baseline levels (Jackson and Jackson 1980; Donovan and Sorini 1986) but would be considered nonhazardous by EPA-RCRA guidelines (Sorini and Donovan 1986).

Additionally, an indirect effect of $0 i 1$ shale processing is the increase in sediment loads to drainage streams. Sediment increase will probably be caused by three factors: (1) process waters that are discharged to a normally dry streambed will increase bank erosion upstream and the sediment load downstream, (2) sediments will increase from spent snale disposal piles, and (3) construction-related soil disturbances will increase sediment load and sheet erosion rates.

Impounding ponds are necessary to prevent sediment influx from affecting areas downstream. In addition, some simple approaches such as compacting spent oil shale with treated process water will reduce sediment influx. Construction operations that compact disturbed lands and wet areas to control dust will also lessen these inpacts.

\section{Water Availability}

The depletion of water in surface and underground aquifers is an area of concern, particularly in the arid West where the richest tracts of oil snale deposits exist. The secondary impacts of water 
management will depend largely on the extent of development. Lowered groundwater levels would increase pumping lifts in wells used for domestic and stock watering purposes; reduced spring flows will affect wildlife watering and will inhibit fishing and irrigation (Bureau of Land Management 1983). Basin-wide groundwater depletion due to excessive mine dewatering practices of a large-scale $(1,000,000$ bbl/day) oil shale operation would have extensive environmental impacts (Lappi et a1. 1982). The greatest cause of water depletion will be the associated population and commercial growth water-use needs (Kilburn 1976). Another effect may be an increase in salinity and a concentration of pollutants and suspended particulates (Ferraro et a1. 1983); however, how this increase will affect aquatic biota is unknown. A study conducted by Western Aquatics on the Piceance Creek in northwestern colorado concludes that increased salinity and suspended particulates will nave little effect on the aquatic biota in that area (Parkhurst 1984). 


\section{BIBLIOGRAPHY FOR WATER QUALITY}

Alley, W. M., L. J. Britton, and E. L. Boyd. "Reconnaissance Evaluation of Water Resources for Hydraulic Coal Mining, Grand Hogback Coal Field, Garfield and Rio Blanco Counties, Colorado," USGS Upen-file Report 78-885, 1978.

Austin, L. H., and G. V. Skogerboe. "Hydraulic Inventory of the Uintah Study Unit," Utah Water Research Laboratory, Salt Lake City, UT, PRWG 40-5, 1970.

Bowden, C. "The Impact of Energy Development on Water Resources in Arid Lands: Literature Review and Annotated Bibliography," University of Arizona, Tucson, Office of Arid Land Studies, Arid Lands Resource Information Paper No. 6.

Cordiviola, S., D. Leist, and R. W. Davis. "Hydraulic Reconnaissance of the Shale Outcrop Area in Kentucky," 1982 Eastern 0il Shale Symposium Proceedings, University of Kentucky, Institute for Mining and Minerals Research, IMMR82/075, 1983.

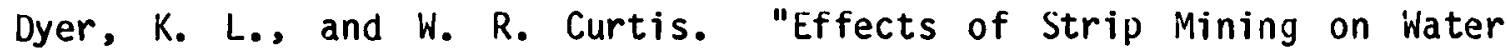
Quality in Small Streams in Eastern Kentucky," U.S. Departinent of Agriculture, Forest Service Research Paper NE-372, 1977.

Farrier, D. S., R. E. Poulson, Q. D. Skinner, J. C. Adams, and J. B. Bower. "Acquisition, Processing and Storage for Environmental Research of Aqueous Effluents from In Situ 0il Shale Processing," The Second Pacific Chemical Engineering Congress Proceedings, Denver, C0, 2, 1977, 1031-1045.

Gauger, W. K., S. E. Williams, D. S. Farrier, and J. C. Adams. "An Analytical Method for Assessing the Quality, by Microbial Evaluation, of Aqueous Effluents UDtained from an In Situ 0il Shale Process," Uil Shale Sampling, Analysis and Quality Assurance Symposium Proceedings, EPA-600/9-80-022, June 1980, 535-545.

Golder Associates. "Movement of Water through a Processed vil Snale Pile," Report to Amoco/Rio Blanco 0il Shale, Lakewood, CO, April 1983.

Groene, G. "Water Quality of Upper Slate Creek and Its Tributaries in Montgomery County, Kentucky," 1984 Eastern 0il Shale Symposium Proceedings, University of Kentucky, Institute for Mining and Minerals Research, Lexington, KY, IMMR84/124, 1985.

Hi11, S. L. "The Toxicity of Rio Blanco Tract C-a Groundwater Samples Before and After the Pumpdown of Retort 1," Western Research Institute, Laramie, WY, September 1986, DOE report in review. 
In Situ, Inc. "Analysis of Water Related Consequences of Shale Disposal in Wheeler Gulch," Mobil Parachute Shale 0il Project, Denver, CO, 1984.

International Engineering Company, Inc. "Water Assessment on Cathedral Bluffs Shale 0il Demonstration Project White River Basin-Colorado," U.S. Water Resources Council, 1981.

Jackson, L. P., R. E. Poulson, T. J. Spedding, T. E. Phillips, and $H$. B. Jensen. "Cnaracteristics and Possible Roles of Various Waters Significant to In Situ 0il Shale Processing," Colorado School of Mines Quarter7y, 70, 1975, 105-134.

Kunn, G., P. B. Daddow, and G. S. Craig, Jr. "Hydrology of Area 54, Northern Great Plains and Rocky Mountain Coal Provinces, Colorado and Wyoming," U.S. Geologic Survey, Water Resources Investigations, Open File Report 83-146, 1983.

Margheim, G. A. "Water Pollution from Spent 0il Shale," Ph.D. dissertation, Colorado State University, Fort Collins, CU, 1975.

Mitsch, W. J., and C. G. Lind. "Potential Impact of 0il Shale Development on Water Resources in Kentucky," 1981 Eastern 0il Shale Symposium Proceedings, University of Kentucky, Institute for Mining and Minerals Research, Lexington, KY, IMMR82/066, 1983.

Nesbitt, P. D., and J. P. Buschur. "Oil Shale Hydrology-A Transfer of Knowledge from the Coal Regions," 1981 Eastern 0il Shale Symposium Proceedings, University of Kentucky, Institute for Mining and Minerals Research, IMMR82/066, 1982.

Peterson, E. J., A. V. Henicksman, J. P. Fox, J. A. O'Rouke, and P. Wagner. "Assessinent and Control of Water Contamination Associated with Shale 0il Extraction and Processing," Los Alamos, NM, October 1, 1979-September 30, 1980, Progress Report LA-9084$P R$.

RBOSL to 0il Snale Officer-D0I. "Monitoring Program for the Appropriation of Springs in the Vicinity of Tract C-a," BLM, March 1983 (phase II) and January 1985 (phase III), Grand Junction, CO.

Slawson, G. C., Jr. "Analysis of Groundwater Quality Sampling Methods," 14th 0il Shale Symposium Proceedings, Colorado School of Mines, Gulden, CO, 1981.

Smith, V. E., and B. L. Weand. "Summary and Analysis of Water Quality at 0il Shale Study Sites," Laramie Energy Research Center, Laramie, WY, JuTy 1977.

Steele, T. D., and J. R. Kunkel. "A Conmparison of Individual ProjectRelated Water-Quality Impacts of Processed-Shale Disposal, Northwestern Colorado," 19th 0il Snale Symposium, Colorado School of Mines, Golden, C0, 1986. 
Summers, P., B. Christensen, E. Janes, K. Thomas, S, Vandas, and B. Van Haveren. "Water Resource Issues and Associated Literature: Piceance Basin, Colorado," BLM report D-471.

Turk, J. T., and D. B. Adams. "Sensitivity to Acidification of Lakes in the Flat Tops Wilderness Area, Colorado," Water Resources Research, $9(2), 1983,346-350$.

U.S. Geologic Survey. "Water Resources Investigations of the U.S. Geologic Survey in Wyoming, Fiscal Year 1983," Open-File Report 83-770, 1983.

VanArsda11, T. C., and C. E. Twilley. "Water Availability for an 0il Shale Industry in Kentucky," 1982 Eastern Uil Shale Symposium Proceedings, Intversity uf Kentucky, Institute for Mining and Minerals Research, Lexington, KY, IMMR82/075, 1983.

Wagner, P., E. J. Peterson, and P. L. Wanek. "Assessment and Control of Water Contamination Associated with Shale Uil Extraction and Processing," Los Alamos, NM, October 1, 1978-September 30, 1979, Progress Report LA-8506-PR.

Water Resources Management Workshop. "0il Snale Development in Northwestern Colorado: Water and Related Land Impacts," Environmental Studies, University of Wisconsin-Madison, IBS Report 48, July 1975.

Wentz, D. A., and T. D. Steele. "Surface Water Quality in the Yampa River Basin, Colorado and Wyoming--An Area of Accelerated Coal Development," presented at Conference on Water For Energy Development, Engineering Foundation, Asilomar Conference Grounds, Pacific Grove, CA, December 5-10, 1976.

Wilber, W. G., and R. R. Boje. "Reconnaissance for Determining Effects of Land Use and Surfacial Geology on Concentrations of Selected Elements on Streambed Materials for the Coal-ilining Region, Southwest Indiana,. October 1979 to March 1980," USGS Water Resources Investigations 82-4013, 1982. 


\section{BIBLIOGRAPHY FOR HASTEMATER}

Adams, J. C., and D. S. Farrier. "The Effect of Some 0il Shale Process waters Upon the Viability of Indicator Bacteria," Journal of Environmental Quality, 11(2), 1982, 171-174.

Farrier, D. S., J. P. Fox, and R. E. Poulson. "Interlaboratory, Multimethod Study of an In Situ Produced 0il Shale Process Water," Oil Shale Sampling, Analysis and Quality Assurance Symposium Proceedings, EPA-600/9-80-022, June 1980, 182-210.

Fox, J. P., P. Persoff, A. Newton, and R. N. Heistand. "The Mobility of Organic Compounds in a Codisposal System," 17 th 0 il Shale Symposium Proceedings, Colorado School of Mines, Golden, Co, 1984.

Gauger, W. K., S. E. Williams, D. S. Farrier, and J. C. Williams. "An Analytical Method for Assessing the Quality, by Microbial Evaluation, of Aqueous Effluents from an In Situ 0il Shale Process," Oil Shale Sampling, Analysis, and Quality Assurance Symposium Proceedings, EPA-600/9-80-022, June 1980, 535-545.

Healy, J. B., B. M. Jones, G. W. Langlois, and C. G. Doughton. "Biotreatment of 0il Snale Wastewaters," 16tn 0il Shale Symposium Proceedings, Colorado School of Mines, Golden, C0, 1983.

Hepler, D. I., A. S. Schafer, K. A. Larson, and D. S. Farrier. "Toxicological Evaluation of an In Situ 0il Shale Process Water," 12th 0il Shale Symposium Proceedings, Colorado School of Mines, Golden, Co, 1979.

Hepler, D. I., A. So Schafer, K. A. Larson, and D. S. Farrier. "Animal Toxicity Evaluation of an In Situ 0il Shale Retort Water," Laramie Energy Technology Center/Report of Investigations-79/T3, Laramie, WY, July 1979.

Hicks, R. E., R. F. Probstein, I. Wei, D. S. Farrier, J. Lotwala, and T. E. Phillips. "Wastewater Treatment and Management at 0il Snale Plants," 13th 0il Shale Symposium Proceedings, Colorado School of Mines, Golden, C0, 1980.

Higgins, T. E., W. F. McTernan, L. A. Schassberger, D. J. Kocornik, and K. J. Stetzenbach. "Physical-Chemical Treatinent of Select 0il Shale Retort Water," 15th 0il Shale Symposium Proceedings, Colorado School of Mines, Golden, CO, 1982.

Hill, S. I.. "Toxicological Characterization of Water Produced During Simulated In Situ Processing of a Reference Shale: A Progress Report," Western Research Center, Laramie, WY, March 1986, DOE report DUE/FE/60177-2187. 
Hines, A. L., E. O. Pedram, S. Punnoose, and R. E. Poulson. "Hot Gas Stripping of 0il Shale Retort Waters," 15th 0il Shale Symposium Proceedings, Colorado School of Mines, Golden, CO, 1982.

Jackson, L. P., and K. F. Jackson. "The Co-Disposal of Retorted 0il Shale and Process Waters: Effect on Shale Leachate Composition," 15th 0il Shale Symposium Proceedings, Colorado School of Mines, Golden, C0, 1982.

Kocornik, D. J. "Characterization of Rio Blanco Retort 1 Water Following Treatment by Lime-Soda Softening and Reverse Usmosis," December 1985, Western Research Institute, Laramie, WY.

Kocornik, D. J., W. F. McTernan, and S. L. Williams. "Treatment of an In Situ Uil Shale Retort Water," Environmental Progress, 4(3), 1985, 145-150.

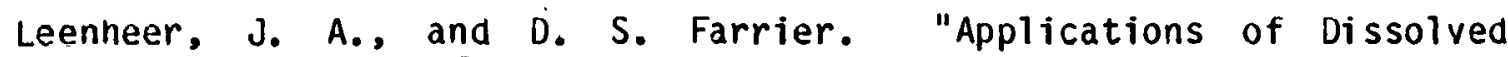
Organic Carbon Fractionation Analysis to the Characterization of 0il Shale Processing Waters," Uil Snale Sampling, Analysis, and Quality Assurance Symposium Proceedings, EPA-600/9-80-022, June 1980.

Lotwala, J. T., D. S. Farrier, and R. E. Poulson. "Control Technology Research Developments for In Situ 0il Shale Process Waters," 2nd U.S. DOE Environmental Control Symposium Proceedings, 1, Fossil Energy, CONF-800334/1, NTIS, Springfield, VA, 1980, 114- $\overline{12}$.

McTernan, W. F., D. J. Kocornik, and E. O. Pedraili. "Pnysical-Cnemical Approaches for the Environmentally Sound Dispersal of an 0i1 Snale Retort Water," Liquid Fuels Technology, 1(4), 1983, 335354.

Mercer, B. W., M. J. Mason, R. R. Spencer, A. L. Wong, and W. Wakamiya. "Evaluation of Physical-Chemical and Biological Treatment of Shale 0il Retort Water," Pacific Northwest Laboratory, Richland, WA, PNL-3449 UC-9 1, 1982.

Mercer, B. W., W. Wakamiya, N. E. Bell, M. J. Mason, R. R. Spencer, C. J. English, and R. G. Riley. "Environmental Control Technology for Shale 0il Wastewaters," Pacific Northwest Laboratories, Richland, WA, PNL-4457 UC-91, 1982.

Misra, M., and Gail Davis. "Cnaracterization and Kecovery of Accessory Trace Elements From Alabama 0il Shale Wastewaters," 1986 Eastern 0il Snale Symposium Proceedings, Kentucky Energy Cabinet Laboratory, Lexington, KY, RECL86-158.

Nelson, K. F., D. S. North, and D. S. Farrier. "ConcentrationDependence of the Effect of an In Situ Oil Shale Retort-Produced Water on Metabolism," Bulletin of Environmental Contamination and Toxicology, 1979. 
Nelson, K. F., D. S. North, G. R. Payne, A. D. Anderson, R. E. Poulson, and D. S. Farrier. "The Effect of an In Situ Produced 0il Snale Processing Water on Metabolism," Archives of Environmental Contamination and Technology, 1 , 1978, 273-281.

Pedram, E., A. L. Hines, R. E. Poulson, and D. 0. Cooney. "Absorption of Urganics from a True In Situ 0il Shale Retort Water on Activated Carbon in Packed Beds," Chemical Engineering Communication, 15, 1982, 291-304.

Peterson, E. J., M. M. Jones, J. Lynn, and W. D. Spall. "Solid/Retort Water Interactions: The Fate of Organics and Inorganics," 17th 0il Shale Symposium Proceedings, Colorado School of Mines, Golden, CO, 1984.

Poulson, R. E., J. A. Clark, and R. Kapil." "Mobile Indicator Species Associated with Uil Shale Retort Water," September 1986, Western Research Institute, Larainie, WY.

Routson, R. C., R. E. Wildung, and R. M. Bean. "A Review of the Environmental Impact of Ground Disposal of 0il Snale Wastes," Journal of Environmental Quality, 8(1), 1979, 14-19.

Sierka, R. A. "A Preliminary Evaluation of 0il Shale Wastewater Treatment by Ozone and Activated Carbon," 15 th 0il Snale Symposium Proceedings, Colorado School of Mines, Golden, Co, 1982.

Stuber, H. A., J. A. Leenheer, and D. S. Farrier. "Inorganic Sulfur Species in Wastewaters from In Situ 0il Shale Processing," Journal of Environmental Science drid Health, 1978, 13(9), 633675.

sung, R. D., and N. P. Colter, "An Evaluation of the Pollution Abatement Technologies Available for Treatment of Wastewater from 0i1 Snale Processing," AICnE Symposium Series No. -166, 73, prt. 1. Water: Physica1, Chemical Wastewater Treatment., 1976. 


\section{BIBLIOGRAPHY FOR LEACHATES}

Barber, Donald R. "Environmental Effects on Quality of Leachate from Simulated In Situ Retorted vil Shale," Master's thesis, Texas Tech University, Lubbock, TX, August 1980.

Brown G. U., and D. B. McWhorter. "Aspects of Liquid and Vapor Flow in Retorted 0il Shale," 1986 Eastern Uil Shale Symposium Proceedings, Kentucky Energy Cabinet Laboratory, KECL86-158, 1987.

Cisler, K., and D. W. Koppenaal. "Leaching Studies on Kentucky Uil Shale Wastes: An Update," 1982 Eastern 0il Shale Symposium Proceedings, University of Kentucky, Institute for Mining and Minerals Research, IMMR32/075, 1983.

Clark, J. A., and S. S. Sorini. "The Quality of Leachate from Retorted Shale Wetted with Treated Process Waters," March 1985, DOE/FE/60177-2224.

Cleave, M. L., V. D. Adams, and D. B. Porcella. "Effects of Oil Shale Leachate on Phytoplankton Productivity," Utah Water Research Laboratory, College of Engineering, Utah State University, Logan, UT, Water Quality Series UWRL/Q-79/05, 1979.

Donovan, R. C., and S. S. Sorini. "Leach Potential of Processed Snale as Determined by Two Extraction Methods," January 1985, DOE/FE/60177-2299.

Esmaili, E., and R. B. Carroll. "Leaching of Retorted Uil Shale Dy Strong Complexometric Agents," January 1985, DOE/FE/60177-2410.

Esmaili, E., R. B. Carroll, and L. P. Jackson. "Assessing Putential Trace Metal Leachability of Retorted $0 i 1$ Shale by Complexometric Agents," 18tn Uil Snale Symposium Proceedings, Colorado School of Mines, Golden, CO, April 1985.

Fox, J. P. "Leaching of Uil Shale Solid Wastes: A Critical Review," Center for Environmental Sciences, dil Shale Task Force, Denver, Cu, 1982.

Fransway, D, F. "Salt Release and Migration in Paraho Processed 0il Shale," Master's thesis, Utah State UnIversity, Logan; UT, 1980.

Gulf Science and Technology. "Lurgi Retorted Shale Leaching Studies," Report to Rio Blanco Oil Shale Company, Harmerville, PA, 1981.

Heistand, R. N., D. B. Jones, and L. L. Morriss. "Free Lime in Retorted 0il Shale," Energy Sources, 1978, 4 (2), 195-202.

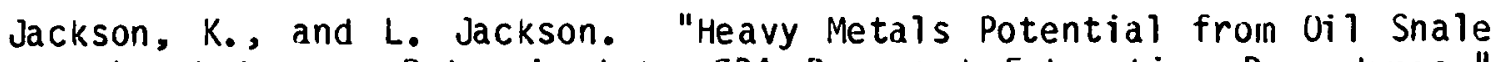
Leachates as Determined by EPA Proposed Extraction Procedures," 13th 0il Shale Symposium Proceedings, Colorado School of Mines, Golden, C0, 1980. 
Jackson, L. P., and K. F. Jackson. "The Co-disposal of Retorted 0il Shale and Process Waters: Effect on Shale Leachate Composition," 15th 0il Shale Symposium Proceedings, Colorado School of Mines, Golden, C0, 1982.

Judzis, A., and B. Williams. "Uranium Removal from Chattanooga 0il Shale by Acid Leaching," 12th 0il Shale Symposium Proceedings, Colorado School of Mines, Golden, C0, 1979.

Koppenaal, D., K. Cisler, and G. Thomas. "Leaching Studies on Kentucky Uil Snale Products," 1981 Eastern Oil Snale Symposium Proceedings, University of Kentucky, Institute for ilining and Minerals Research, IMMR82/066, 1982.

McGowen, L. J. "Examinations of Batch and Column Procedures Used to Produce a Leachate from Retorted 0il Shale," Western Research Institute, Laramie, WY, May 1985, DOE/FE/60177-1954.

McNight, D. M., W. E. Pereira, C. E. Rostad, and E. A. Stiles. "Effect of Retorted 0il Shale Leachate on a Blue-Green Alga (Anabaena flos-aquae)," Bulletin of Environmental Contamination and Toxicology, 30, 2983, 6-16.

Pacific Northwest Laboratories. "Uil Snale Retorted by the Lurgi Process: Mineralogy and Effects of Simulated Weathering on Leachate Composition," Report for U.S. Department of Energy, Contract No. DE-ACO6-75R10-1830, Richland, WA, 1975.

Peterson, E. J., and P. Wagner. "Some Chemical and Mineralogical Considerations Important for Understanding Leachate Cheinistry," 15th Uil Shale Symposium, Colorado School of Mines, Golden, CU, 1982.

Ramirez, W. F., P. T. Morelli, and W. R. Peterson. "Porous Media Properties, Leaching Capacity, and Transport Properties of Soluble Pollutants from Spent 0il Snale," 15 th 0il Shale Symposium Proceedings, Colorado School of Mines, Golden, Co, 1982.

Rob1, T. L., K. Cisler, G. Thomas, and D. Koppenaal. "Leaching Characteristics of Eastern 0il Shale: First Year Data Summary of the Hope Creek Study," 1985 Eastern 0il Shale Symposium Proceedings, Kentucky Energy Cabinet, KCERL/85-147, 1986.

RoDl, T., J. Ubley, G. Thomas, W. Jones, and M. Shirav. "Elemental Release Characteristics of Eastern Uil Shales: Comparison of Field and Laboratory Results," 1986 Eastern 0il Snale Symposium Proceedings, Kentucky Energy Cabinet Laboratory, KECL85-158, 1987.

Saffer, A., J. Siler, and D. Bhatta Charyya. "Leacning Behavior of Retortcd and Oxidized Eastern. Uil Shale," 1982 Eastern 0il Shale Symposium Proceedings, University of Kentucky, Institute for Mining and Minerals Research, IMMR82/075, 1983. 
Sorini, S. S., and R. C. Donovan. "EPA, ASTM, and Column Leaching of Processed 0il Shale," 19th 0il Shale Symposium Proceedings, Colorado School of Mines, Colden, CU, 1986.

Stollenwerk, K. G., and D. D. Runnells. "Composition of Leachate from Surface-retorted and Unretorted Colorado vil Shale," Environmental Science and Technology, 15(11), November 1981, $1340-1345$.

Thode, E. F., E. J. Peterson, and P. Wagner. "Multistage Leaching of Spent Modified In Situ Oil Shale Retorts," Los Alamos Scientific Laboratory, Los Alamos, NM, of California, LA-8744-MS, 1981.

Tian, J.., and W. D. Enmann. "Elemental Release from Kentucky Raw and Retorted Shales hy leaching," 1984 Eastern 0il Shale Symposium Proceedings, University of Kentucky, Institute for Mining and Minerals Research, IMMR84/124, 1985.

U.S. Department of Energy. "Final Report Phase II Collaborative Test Program: Analysis of Selected Trace Metals in Leachate from Selected Fossil Energy Materials," DUE Engineering-Science, Washington, DC, 1980.

Watts, Jackie C. "Ground Water Leaching of In Situ Retorted 0il Shale," Master's thesis, Texas Tech University, Lubbock, TX, December 1977. 


\section{RECLAMATION AND BIOLOGY \\ by Rhonda James}

Lands disturbed by energy development must be reclaimed. Retorted oil shale nas up to $25 \%$ more volume than the original unprocessed rock, posing a disposal problem. (A nypothetical 50,000 Dbl/day plant could produce as much as $260,000 \mathrm{ft}^{3} /$ day of spent shale in excess of that mined. This production would be sufficient to cover Washington, D.C., an area of 65 square miles, to a depth of $1 / 2$ inch in a year (Pfeffer 1974).) Spent shale is nighly saline, nighly alkaline, and low in available phosphorous and nitrogen, which are essential to plant growth (Schmehl et al. 1973). It also contains concentrations of boron, heavy metals, and trace elements, which deleteriously affect plant growth. In spite of the negative consequences of using spent shale as a plant growth medium, revegetation experiments on oil shale disposal piles have been successful. However, extended cuitural input, such as fertilizing, mulching, irrigation, and addition of topsoil, seems to be indicated by most researchers (e.g., Schmehl et al. 1973; Kilburn 1976; Mckel1 1976; Hamon et al. 1981; Redente et a1. 1981). Interestingly, a preliminary study by Heistand and Limbach (1987) with spent shale piles near Anvil Points, Colorado, shows that the natural invasion of native plants on retorted shale disposal piles is not significantly different from the natural revegetation of disturbed soils. This study may indicate an economical alternative to expensive reclamation plans; however, more studies need to be conducted.

\section{Ecology}

Ecosystem recovery requires reclamation of oil shale mined 1ands. According to the Federal Register, disturbed lands must be returned to a usable and productive condition compatible with existing, adjacent, undisturbed natural areas by supporting flora and fauna of the same type and kinds and in the same quantities that existed before development. Most preliminary biological studies are designed to assess abundance and distribution of life forms in terrestrial and aquatic biota. Such baseline information is essential to recovery; however, without detailed analysis of cause-and-effect relationships, very little can be assessed regarding ecosystem recovery (Ashiand 0i1, Inc. 1974-1975).

\section{Impacts}

Land reclamation is the most important factor in mitigating extended environmental impacts to developed areas. Aboveground oil shale production, as opposed to modified and true in situ production, is of the greatest environmental concern. Three phases of aboveground production can potentially affect the environment: the mining process, extraction of shale, and disposal of processed shale. In the mining process, aquifer disruption, runoff, and leaching of process wastes to groundwaters may affect streams and rivers. Crushing, retorting, and refining the shale can cause potentially narinful gaseous emissions and fluid effluents that contain organics and 
inorganics, macro-ions, and trace metal residues. The disposal of spent shale results in recreational land loss, reclamation/revegetation problems, and environmental and numan exposure to resuspended particulates and leached pollutants in groundwater and surface waters (Vaughn et a1. 1979). Retorted oil shale has up to $25 \%$ more volume than the original unprocessed rock, which poses a disposal problem unique to the oil shale industry.

Ecosystem can be defined as an environment that will support all coexisting species of life, including aquatic, terrestrial, and soil macro- and micro-organisms. No wild species, plant or animal, can effectively live without an intact ecosystem (Crowe 1931). Disruptions to ecosystems result from three factors: (1) physical modifications of the environment by complex structures, e.g., spent shale disposal embankments, roads, powerlines, (2) interruption of natural processes such as erosion, stream-flow, and animal migration by dams, reservoirs, roads, or other diversion systems, and (3) increased numan use of land previously unoccupled or undisturbed (Kilburn 1976). Of particular concern are impacts that affect endangered wildiife and plant species. Although reclamation standards are covered by federal and state regulations, few laws exist protecting areas that should not be developed, or developed only as a last resort. These areas are "unique and critical" haibitats. Unique nabitats include aquatic environments, riparian habitats, rimrocks and arid shrublands; critical habitats are high use wildlife areas which limit the number of animals an entire region can support. These nabitats cannot be replaced by reclamation (Strickland 1980).

Revegetation of disturbed areas must be correlated with habitat and ecosystem recovery. The type and kinds of vegetation introduced into an area will determine the variety of fauna. Bacteria and mycorrhizae (a fungus-root symbiosis), requisites for healthy phytotaxic development, are absent from retorted shale soil substitutes, and studies have shown that spent shale causes a distorted or unnatural root type which may affect normal plant growth (Redente et al. 1981). 


\section{BIBLIOGRAPHY FOR FLORA/FAUMALAMD}

Adams, J. C., and D. S. Farrier. "The Effect of Some 0il Shale Process Waters upon the Viability of Indicator Bacteria," Journal of Environmental Quality, 11(2), 1982, 171-174.

Anderson, A. D., M. E. Lebsack, G. M. Degraeve, D. S. Farrier, and $H$. L. Bergman. "Toxicity of an In Situ 0il Shale Process Water to Rainbow Trout and Fatnead Minnows," Archiver of Environmental Contamination Tóxicology, 9, 1980, 171-179.

Bergman, H. L. "Final Progress Report, January 1980-ivovember 1981, Effects of Aqueous Effluents from In Situ Fossil Fuel Processing Technologies on Aquatic Systems," Fish Physiology and Toxicology Laboratory, Department of Zoology and Physiology, University of Wyoming, Laramie, WY, 1985.

Bergman, H. L., and J. S. Meyer. "Aquatic Ecosystem Effects of Process Waters Produced by Synthetic Fuel Technologies," Summary Report: 1981-1982, University of Wyoming/U.S. Environmental Protection Agency Cooperative Agreement CR808671.

Bergman, H. L., G. M. Degraeve, A. D. Anderson, and D. S. Farrier.: "Effects of Complex Effluents from In Situ Fossil Fuel Processing: on Aquatic Biota," 1st Life Science Symposium on Potential Health. and Environmental Effects of Synthetic Fossil Fuel Technologies Proceedings, Oak Ridge National Laboratories, Uak Ridge, TN, July 1979, 204-211.

Ceray, L. J., and J. V. Ward. "Potential Effects of vil Snale, Extraction and Processing Activities on Microinvertebrates of Piceance and Black Sulfur creeks, Colorado," Fort Collins, Cu, Colorado State University, Department of Zoology and Entomology, Environmental Research Paper 10, 1977.

Dahmer, D. T., N. C. Forrester, J. M. Locknart, and T. P. McEneaney. "Nest Box Use by American Kestrels on and around Western Surfacemined Land," Issues and Technology in the Managenent of Impacted Western Wildife Symposium Proceedings, Thorne Ecological Institute, Denver, CO, 1982.

Delistraty, D. A. "Growth and Photosynthetic Response of Freshwater Alga, Selenastrum capriocornutum, to an $0 i 1$ Shale By-product Water," Bulletin of Environmental Contamination and Toxicology, $1986,36(1), 114-121$.

Ecology Consultants, Inc. "Final Report for the Terrestrial Baseline Data Accumulation Program," Fort Collins, C0, December 1976.

Goett1, J. P., and J. W. Edde. "Environinental Effects of Uil Shale Mining and Processing: Part 1-Fishes of Piceance Creek, Colorado, Prior to of 1 Snale Processing," Environmental Research Laboratory, Office of Research and Development, U.S. EPA, Duluth, MN, October 1978, EPA-600/3-78-096. 
Gray, L. J., and J. V. Ward. "Environmental Effects of 0il Shale Mining and Processing: Part II-The Aquatic Macroinvertebrates of the Piceance Basin, Colorado, Prior to 0il Shale Processing," Environmental Research Laboratory, Office of Research and Development, U.S. EPA, Duluth, MN, October 1978, EPA-600/3-78097.

Hoover, L., and D. L. Wills, eds. Managing Forested Lands for Wildlife, Colorado Division of Wildlife in cooperation with USDA Forest Service, Rocky Mountain Region, Denver, CO, 1984.

Howard, R. P., and M. Hilliard. "Artificial Nest Structures and Grassland Raptors," Raptor Research, 14, 1980, 41-45.

Lebsack, M. E., A. D. Anderson, K. $F$. Nelson, and D. S. Farrier. "Sublethal Effects of an In Situ uil Snale Retort water on Rainbow Trout," Toxicology and Applied Pharmacology, No. 54, $1980,462-468$.

Marcus, M. D., H. L. Bergman, D. A. Stoller, S. K. Brown, and P. A. Molnolt. "Bibliography of Aquatic Ecosystem Effects, Analytical Methods and Treatment Technologies for Organic Compounds in Advanced Fossil-Fuel Processing Effluents," Environmental Research Laboratory, Office of Research and Development, U.S. EPA, Duluth, MN, 1980, EPA-600/3-80-026; Volume 2, 1980, EPA600/3-80-086.

Mariah Associates. "Assessment of Impact to Wildiife at Seminoe II Mine, Hanna Basin, Carbon County, Wyoming;" Laramie, WY, prepared for Arch Mineral Corporation, Hanna, WY, August 1979.

O'Meara, T. E., J. B. Haufler, L. H. Stelter, and J. G. Nagy. "Nongame Wildlife Responses to Chaining of Plnun-Juniper Woodlands," Journal of Wildlife Management, 45(2), 1981, 381-389.

Parkhurst, B. R. "An Assessment of the Biological Impacts of the Yellow Creek Diversion Project to the White River," Western Aquatics, Inc., Laramie, WY, 1984.

Postovit, H. R., J. W. Grier, J. M. Lockhart, and J. Tate, Jr. "Directed Relocation of a Golden Eagle Nest Site," Journal of Wildlife Management, 46(4), 1982, 1045-1048.

Reed, E. B. "Is There a Fishery on Piceance Creek, Colorado?", ERT/Ecology Consultants, Inc., Fort Collins, CO, May 1979.

Reed, E. B. "Evaluation of the Biological Productivity of Piceance Creek," ERT/Ecology Consultants, Inc., Fort Collins, C0, January 1979.

Richardson, S. G., and C. M. McKe11. "Growth Response of Two Saltbush Species to Nitrate, Ammonium, and Urea Nitrogen Added to Processed Oil Shale," Journal of Kange Management, 34, 1981, 424425. 
Rio Blanco 0il Shale Project. "Fish and Wildlife Management Plan," Bureau of Land Management, Craig, C0, September 1975.

Rost, G. R., and J. A. Bailey. "Distribution of Mule Deer and Elk in Relation to Roads," Journal of Wildlife Management, 43(3), 1979, 534-641.

Schmen1, W. R., and B. D. McCaslin. "Some Properties of Spent 0il Shale Significant to Plant Growth," Ecology and Reclamation of Devastated Land, Hutnik, R. J., and G. Davis, eds.; London: Gorden and Breach, 1973.

Skinner, Q. D., and J. M. Carson. "Vegetative Evaluation of Procedures Used to Treat Aqueous Effluents Derived from In Situ Fossil Fuel Processing," U.S. Department of Energy, Office of Fossil Energy, Morgantown Energy Technology Center, Morgantown, WV, DOE/LC/10917-1735 (DE85003365).

Skinner, Q. D., T. S. Moore, R. 0. Asplund, J. C. Sexton, and D. S. Farrier. "Pnytotoxicity and Plant Response to Aqueous Effluents Derived from an In Situ 0il Shale Process," 12th 0il Shale Symposium Proceedings, Colorado School of Mines, Golden, Co, 1979.

Skinner, Q. D., T. S. Moore, R. 0. Asplund, J. C. Sexton, and D. S. Farrier. "Plant Responses to Aqueous Effluents Derived from In Situ Fossil Fuel Processing: I. Development of Screening Methods," Laramie Energy Technology Center, Laramie, WY, 1979.

Skinner, Q. D., T. S. Moore, and J. C. Sexton. "Response of Range Grasses to Water Produced from In Situ Fossil Fuel Processing," Reclamation and Revegetation Research, 3, 1984, 239-250.

The Nature Conservancy. "Inventory of the Piceance Basin, Colorado: Threatened and Endangered Plants, Plant Associations, and the General Flora," 5 Vols. Colorado Natural Heritage Inventory, Bureau of Land Management Contract No. YA-553-CTI-116, Denver, C0, 1982.

Vaughan, B. E. "Pacific Northwest Laboratory Annual Report for 1978 to the DOE Assistant Secretary for Environment: Part 2 Ecological Sciences," Pacific Northwest Laboratory, Richland, WA, PNL-2850 PT2 UC-11.

Welsh, S. L. "Endangered and Threatened Plants of Utan: A Reevaluation," The Great Basin Naturalist, 38, March 1978, 1-18.

Woods, L. E. "Boron Toxicity to Plants from Spent Uil Snales," Master's Thesis, Colorado State University, Fort Collins, Co, 1977. 
Wyoming Game and Fish Department (WGFD). "Wildlife UDservation System," Cheyenne, WY, 1980. 


\section{BIBLIOGRAPHY FOR LAND}

Bowden, C. "The Impact of Energy Development on Water Resources in Arid Lands: Literature Review and Annotated Bibliography," University of Arizona, Tucson, Office of Arid Land, Studies, Arid Land Resource Paper, No. 6, 1980.

Frickel, D. I. $_{0}$. L. M. Shown, and P. C. Patton. "An Evaluation of Hillslope and Channel Erosion Related to 0il Shale Development in the Piceance Basin, Northwest Colorado," Colorado Water Conservation Board Water-Resources Circular No. 30, 1975.

Leenheer, J. A., H. A. Stuber, and T. I. Noyes. "Chemical and Physical Interactions of an In Situ 0i1-Shale Process Water with a Surface Soil," 14tn 0il Shale Symposium Proceedings, Colorado School of Mines, Golden, C0, 1981. 


\section{BIBLIOGRAPHY FOR SITE RESTORATION/REVEGETATION}

Barnhisel, R. I., and R. R. Kruspe. "0il Shale Revegetation Research at the Hope Creek Project," 1985 Eastern Oil Shale Symposium Proceedings, Kentucky Energy Cabinet, Lexington, KY, KCERL/85$147,1986$.

Barnhisel, R. I., and R. R. Kruspe. "Reclamation Research Results from the Hope Creek Eastern 0il Shale Field Station," 1986 Eastern 0il Shale Symposium Proceedings, Kentucky Energy Research Laboratory, Lexington, KY, KECL86-158, 1987.

Block, M. B., and P. D. Kilburn, eds. Processed Shale Revegetation Studies, Colony Development Operation, Denver, CO, 1973.

Cook, C. W., R. M. Hyde, and P. L. Sims. "Guidelines for Revegetation and Stabilization of Surface Mined Areas in the Western States," Colorado State University, fort Collins, CU, Range - Science Department, Sci. Ser. 16, 1974.

Crofts, K. A., and C. M. Mckell. "Sources of Sceds and Planting Materials in the Western States for Land Rehabilitation Projects Emphasizing Native Plant Species," Inst. for Land Renabilitation, College of Natural Resources, Utah State University, Logan, UT, Agricultural Experiment Station, Land Rehabilitation Series No. 4. 1977.

Culbertson, W. J., Jr., T. D. Nevens, and R. U. Hollingshead. "Disposal of Oil Shale Ash," Colorado School of Mines Quarterly, 65(4), 1970, 89-132.

Fransway, D. F. "Salt Release and Migration in Paraho Processed 0il Shale," Master's Thesis, Utan State University, Logan, UT, 1980.

Frischknect, N. C., and R. B. Ferguson. "Revegetating Prucessed 0i1 Snale and Coal Spills on Semi-Arid Lands," U.S. EPA, Uffice of Research and Development, Cincinnat1, OH, 1979, EPA-600/7-79-068.

George, M. L., C. M. McKell, and S. G. Richardson. "The Establishment of Cheatgrass (Bromus tectorum L.) on Spent 0il. Shale from the Paraho Process," Journal of Environmental Quality, 10, 19.81, 166169.

Hamon, W. R., and R. R. Kruspe. "Preliminary Research on Potential Reclamation of 0il Shale Mined Lands in Kentucky," 1981 Eastern vil Shale Symposium Proceedings, University of Kentucky, Institute fur Mining and Minerals Research, Lexingtan, KY. IMMR82/066, 1982.

Harbert, H. P., III, and W. A. Berg. "Vegetative Stabilization of Spent 0il Shales," Colorado State University Environmental Resources Center, Technical Report No. 4, Fort Collins, Co, 1974. 
Harbert, H. P., III, W. A. Berg, and D. McWhorter. "Vegetative Stabilization of Paraho Spent 0il Shales: Lysimeter Study, 19761977," U.S. EPA, Office of Research and Development, Cincinnati, $0 H$, 1977, EPA 600/7-78-021.

Heistand, R. N., and L. K. Limbach. "The Natural Invasion of Native Plants on Retorted 0il Shale," 20th 0il Shale Symposium Proceedings, Colorado School of Mines, Golden, Co, 1987.

Herron, J. T., W. A. Berg, and H. P. Harbert, III. "Vegetation and Lysiineter Studies on Decarbonized Shale," Colorado State University Experimental Station Technical Bulletin, 1980.

Hower, J. M., R. I. Barnhisel, and T. C. Hopkins. "Potential Use of Borden and Bedford Shales as Topsoil Substitutes," 1982 Eastern 0il Snale Symposium Proceedings, University of Kentucky, Institute for Mining and Minerals Research, Lexington, $K Y$, IMMR82/075, 1983.

Kilburn, P. D. "Environmental Implications of 0il Snale Development," Environinental Conservation, $3(2), 1976,101-114$.

Kilkelly, M. K., H. P. Harbert, III, and W. A. Berg. "Field Studies on USBM and TOSCO II Retorted Uil Shale," U.S. EPA, Office of Research and Development, Cincinnati, OH, 1981.

Kilkelly, M. K., H. P. Harbert, III, and W. A. Berg. "Field Studies on Paraho Retorted Uil Shale Lysimeters," U.S. EPA, Office of Research and Development, Cincinnati, $\mathrm{OH}, 1981$, in press.

Koppenaa1, D. W., R. R. Kruspe, T. L. Robl, K. Cisler, and D. L. Allen. "The Examination of Eastern 0il Shale Disposal ProblemsThe Hope Creek Field Study," 1984 Eastern 011 Shale Symposium Proceedings, University of Kentucky, Institute for liining and Minerals Research, Lexington, KY, IMMR84/124, 1985.

Lipman, S. C. "Union 0il Company Revegetation Studies," Environmental Dil Shale Symposium Proceedings, Colorado School of Mines Press, Golden, C0, 70, 1975, 165-180.

McKell, C. M. "Achieving Effective Revegetation of Disposed 0il Shale: A Program Emphasizing Natural Methods in an Arid Environment," Agricultural Experiment Station, College of Natural Resources, Utan State University, Logan, UT, 1976.

McKel1, C. M., G. Van Epps, and S. G. Richardson. "Revegetation Studies for Uisturbed Areas and Processed Snale visposal Sites," Final Report to White River Shale Project, Utan State University, Logan, UT, Institute for Land Rehabilitation, 1979.

Merino, J. M., and R. B. Crookston. "Reclamation of Spent 0il Shale," Mining Congress Journa 1, 10, 1977, 31-36. 
Redente, E. F., and C. W. Cook. "Revegetation Research on $0 i 1$ Shale Lands in the Piceance Basin," Research Report, Colorado State University, Fort Collins, C0, 1981.

Redente, E. F., and C. W. Cook. "Revegetation Studies on 0il Shale Related Disturbances in Colorado," Colorado State University, Fort Collins, C0, Report No. DOE/EV04018-6.

Rio Blanco 0il Snale Company. "Revegetation Program 1977 Annual Report," Gulf 0il Corp. and Standard 0il Co. (Indiana), Denver, CO, 1978.

Rio Blanco 0il Shale Company. "Revegetation Program 1978 Annual Report," Gulf 0il Corp. and Standard 0il Co. (Indiana), Denver, CO, 1979 .

Scnmeh1, W. R., and B..D. McCaslin. "Some Properties of Spent 0il Snale Significant to Plant Growth," Ecology and Reclamation of Devastated Lands, Hutnik, R. J., and G. Davis, eds.; London: Gorden and Breach, 1973.

Woods, L. E. "Boron Toxicity to Plants from Spent 0il Snales," Master's Thesis, Colorado State University, Fort Collins, Co, 1977. 


\section{HEALTH AND SAFETY \\ by James Dean}

Health and safety guidelines cover the exposure of the public and workers to environmental factors that may impair nealth or threaten safety. An oil shale plant is a combination of a mine and a refinery; thus, many of the hazards of mining and refining also apply to oil shale development (e.g., cancer, respiratory diseases, and hearing loss) (Gratt 1983). Respiratory diseases are caused by excessive inspiration of particles. The nature and number of particles, how the particles are deposited and retained, the coexisting innaled agents (including tobacco smoke), and the response of the individual are the deciding factors in respiratory disease (Marine et al. 1984).

\section{Health}

The most serious nealth hazards for oil shale industry workers are cancer, respiratory disease, and hearing loss (Gratt 1983).

\section{Cancer}

Developing cancer as a result of exposure to oil shale-related chemicals is due to four factors: (1) the effect of an individual chemical, (2) the degree of exposure, (3) the toxicology of the chemicals in the total population of exposed people, and (4) the population at risk (Savitz et al. 1984). The carcinogenic chemicals are the polycyclic aromatic nydrocarbons (e.g., benzo(a)pyrene) and the polycyclic aromatic primary amines. The former are. common to petroleum oils, and the latter are unique to oil shale. The degree of exposure to carcinogenic chemicals varies with the process (mining, crushing, retorting, refining, transportation), the proximity of the exposed workers or public, the contact vector (e.g., inhalation, skin contact), and the cumulative time.

The expected incidence and fatality rates of cancer in a nypothetical oil shale plant are listed in Table 28.

Many factors affect the rate and incidence of cancer in a population exposed to a new source of carcinogens. One of these factors is the previous history of workers and others exposed to oil shale products (e.g., tobacco use, previous exposure to carcinogenic material factors) (Costel1 1982). Some combinations of chemicals found in oil shale and exposure to light greatly predispose individuals to skin cancers (Selby et a1. 1983). The public living close to an oil shale facility would have an increased risk of developing cancer in subsequent years. An estimated 15 premature deaths per year (with a range of 0-76 deaths) would occur in a region with 616,000 people. In the U.S. population as a whole (estimated at 313 million people in 2010), 27 premature deaths due to oil shale developement would occur (Perry and Gratt 1984). 
Table 28. Cancer Incidence and Fatality Rates

(per 15,000 workers for a one million

gal/day plant)

\begin{tabular}{|c|c|c|c|c|c|}
\hline $\begin{array}{l}\text { Type of } \\
\text { Cancer }\end{array}$ & $\begin{array}{l}\text { Excess } \\
\text { Incidence } \\
\text { per } 1,000 \\
\text { per Year }\end{array}$ & $\begin{array}{l}\text { New Cases } \\
\text { per Year }\end{array}$ & $\begin{array}{l}\text { Fatality } \\
\text { Rate (\%) }\end{array}$ & $\begin{array}{l}\text { Best } \\
\text { Estimate } \\
\text { (fatality/ } \\
\text { year) }\end{array}$ & $\begin{array}{c}\text { Range } \\
\text { (Fatality/ } \\
\text { year) }\end{array}$ \\
\hline Lung & 0.115 & 1.73 & 91 & 1.57 & $0.16-16.0$ \\
\hline Stomach & 0.039 & 0.59 & 88 & 0.52 & $0.052-5.2$ \\
\hline Kidney & ก,ก>? & 0.33 & 56 & 0.18 & $0.018-1.8$ \\
\hline Brain & 0.069 & 1.04 & 82 & 0.85 & $0.085-8.5$ \\
\hline Skin & & & & & \\
\hline Me la noma & 0.029 & 0.44 & 38 & 0.17 & $0.017-1.7$ \\
\hline Basal & 1.080 & 16.20 & 1 & 0.16 & $0.012-2.1$ \\
\hline Squamous & 0.290 & 4.35 & 1 & 0.04 & $0.003-0.52$ \\
\hline
\end{tabular}

ancidence above the population's background rate

${ }^{D}$ New cases attributable to exposure to oil shale derivatives

Although air emissions and skin contact are the primary modes of exposure to carcinogens frl oil shale developement, there is also a risk associated with solid waste leachates of metals and organics. Estimating the degree of exposure is difficult because transport meenanisms, water treatment before consumption, ingestion patterns and quantities, contributions from otiner sources, and sensitivities vary without predictability. The risks of exposure are expected to be minima 1 .

\section{Respiratory Diseases}

Human lungs cannot repair damage caused by excessive inhalation of particles. The lungs' response to increased inhalation of dust particles depends on the nature and number of specific particles, now they are deposited and retained, coexisting inhaled agents (including tobacco smoke), and the response of the individual (Marine et al. 1984).

There are four types of respiratory diseases that can be caused by exposure to dust from an oil shale plant. Pneumoconiosis is the deposition of dust in the lungs resulting in inflamation that causes fibrosis. Silicosis is a type of pneunoconiosis that develops from innaling free silica (quartz) dust; the result is a formation of small, individual nodules in the lungs. Chronic bronchitis is a recurrent excess of mucus secretion in the bronchial tubes. Chronic airway obstruction is an increased resistance to the passage of air in and out of the lung due to narrowing of the small airways of the 
bronchial tree. The predicted incidence of pulmonary disease for workers exposed to dust from an oil shale plant are listed in Table 29.

Table 29. Summary of Pulmonary Disease Risk for 20,400 Workers Exposed to Dust

\begin{tabular}{|c|c|c|c|c|}
\hline Di sease & $\begin{array}{l}\text { Fatality } \\
\text { Rate } \\
(\%)\end{array}$ & $\begin{array}{l}\text { Excess } \\
\text { Cases } \\
\text { per } 1000 \\
\text { per Year }\end{array}$ & $\begin{array}{l}\text { Cases } \\
\text { per } \\
\text { Year }\end{array}$ & $\begin{array}{l}\text { Premature } \\
\text { Fatalities } \\
\text { per Year }\end{array}$ \\
\hline Silicosis & 33 & $\begin{array}{r}14.5^{\mathrm{a}} \\
2.0^{\mathrm{D}}\end{array}$ & $\begin{array}{r}295 \\
41\end{array}$ & $\begin{array}{l}97 \\
13\end{array}$ \\
\hline $\begin{array}{l}\text { Simple } \\
\quad \text { Pneumoconiosis }\end{array}$ & 16 & $\begin{array}{l}6.4^{\mathrm{a}} \\
2.1^{\mathrm{b}}\end{array}$ & $\begin{array}{r}130 \\
43\end{array}$ & $\begin{array}{r}21 \\
7\end{array}$ \\
\hline $\begin{array}{l}\text { Complicated } \\
\text { Pneumoconiosis }\end{array}$ & 23 & $\begin{array}{l}0.55^{\mathrm{a}} \\
0.03^{\mathrm{b}}\end{array}$ & $\begin{array}{r}11 \\
0.5\end{array}$ & $\begin{array}{l}2.6 \\
0.1\end{array}$ \\
\hline $\begin{array}{l}\text { Chronic } \\
\text { Bronchitis }\end{array}$ & 38 & $\begin{array}{l}2.0^{\mathrm{a}} \\
0.0^{\mathrm{D}}\end{array}$ & $\begin{array}{r}41 \\
0\end{array}$ & $\begin{array}{r}15 \\
0\end{array}$ \\
\hline $\begin{array}{l}\text { Chronic Airway } \\
\text { Obstruction } \\
\text { (FEV1 less } \\
\text { than 65\%)* }\end{array}$ & 44 & $\begin{array}{l}0.73^{a} \\
0.0^{b}\end{array}$ & $\begin{array}{r}15 \\
0\end{array}$ & $\begin{array}{l}6.6 \\
0\end{array}$ \\
\hline
\end{tabular}

${ }^{2}$ Exposure at the nuisance dust level:

$1 \mathrm{mg}$ (dust) $/ \mathrm{m}^{3}$ with $10 \%$ free silica

${ }^{D}$ Exposure at the silica threshold limit level:

$1 \mathrm{mg}$ (dust) $/ \mathrm{m}^{3}$ with $10 \%$ free silica $\left(100 \mathrm{\mu g} / \mathrm{m}^{3}\right.$ )

\section{Hearing Loss}

Hearing loss due to sound exposure typically first occurs at the $4000 \mathrm{~Hz}$ frequency. This is the most noise sensitive frequency which is very important for interpreting and recognizing speech, (EPA 1974). The following high frequency hearing loss cases have been estimated for a population of 20,400 oil shale workers (Gratt 1983):

Excess Incidents per 1000 per Year.................. 1.4

Cases per Year................................ 28.6

Uncertainty Range............................ 9.9-82.3 
0il shale development combines mining, ore processing, retorting, refining, and transportation of processed shale oil. 0il shale processing involves heavy equipment, heat, dust, and related environmental factors that can cause safety hazards.

Accidents

A one million bbl/day oil shale industry would have a workforce of 41,000 (range 35,000-49,000). Assuming a linear relationship between predicted statistics for a workforce of that size, the same accident rate per worker can be assumed for any size oil shale facility. This might include a pilot-sized operation employing a hundred or so workers. These predictions would be conservative, since large mining operations tend to be safer than smaller ones (Gratt et a). 1984). The anticipated occurrences of accidents for an oil shale facility of one million bbl/day production are listed in Table 30. The figures include estimates per worker, making them transferable (within reason) to oil shale developments of smaller size.

An oil shale facility would be safer than coal mining; but, it is more hazardous than the all-industry average. In general, oil shale work would be a moderately dangerous activity requiring substantial planning by industry for safety in designing facilities and training the workforce.

\section{Disasters}

0il shale mining would have many of the same risks of explosions and fires as coal mining because of the ignitability of fine oil shale dust. In tests, fine oil shale dust can be ignited thermally as easily as Pittsburg coal (Cashdollar et a1. 1984). Although blasting would not be as potentially hazardous as in coal mining (Weiss et al. 1986), the potential for oil snale mine disasters remains. One problem is that by adding a small amount of methane, the energy required for ignition and propagation of secondary explosions is greatly reduced. This means that although oil shale dust per se is not as conducive to explosion as coal dust, a small amount of methane (2\%) would be enough to cause a serious explosion of vil shale dust (Richmond and Beitel 1984). Methane is present in oil shale (26 feet ${ }^{3}$ of methane per ton of shale) (Sapko and Richmond 1982). Al though not mobile due to low rock permeability, methane can be released to mine atmospheres by fractures from mining and blasting. Its release is irregular and unpredictable (Vinson et al. 1979). Although the mining of almost 3 million metric tons of oil shale nas not resulted in an explosion due to oil shale dust (Crookston and Hoskins 1979), the potential for a disastrous explosion still exists. 0il shale developers need be very conservative in designing mining facilities to prevent the accumulation of conditions which might cause an explosion. 
Table 30. Annual Accident and Injury Occurrences for a One Million BPD Oil Shale Industry

\begin{tabular}{|c|c|c|c|c|}
\hline \multirow[b]{2}{*}{ Work Group } & \multirow{2}{*}{ ' } & \multicolumn{2}{|c|}{ Occurrences (Range) } & \multirow[b]{2}{*}{$N L^{b}$} \\
\hline & & Fatalities & $N F D L^{a}$ & \\
\hline Mining & & $\begin{array}{c}7.1 \\
(4.6-11)\end{array}$ & $\begin{array}{c}1600 \\
(1100-2400)\end{array}$ & $\begin{array}{c}440 \\
(290-660)\end{array}$ \\
\hline Crushing & & $\begin{array}{l}2.2 \\
(1.1-4.4)\end{array}$ & $\begin{array}{c}310 \\
(210-460)\end{array}$ & $\begin{array}{c}170 \\
(110-280)\end{array}$ \\
\hline $\begin{array}{l}\text { Retorting and } \\
\text { Upgrading }\end{array}$ & & $\begin{array}{c}1.7 \\
(.61-4.8)\end{array}$ & $\begin{array}{c}130 \\
(51-340)\end{array}$ & $\begin{array}{c}300 \\
(120-770)\end{array}$ \\
\hline Construction & & $\begin{array}{c}0.77 \\
(.54-1.1)\end{array}$ & $\begin{array}{c}140 \\
(100-190)\end{array}$ & $\begin{array}{c}280 \\
(200-390)\end{array}$ \\
\hline Refining & ' & $\begin{array}{c}1.00 \\
(.67-1.5)\end{array}$ & $\begin{array}{c}78 \\
(18-1100)\end{array}$ & $\begin{array}{c}180 \\
(27-240)\end{array}$ \\
\hline Transportation & & $\begin{array}{c}0.5 \\
(.10-2.5)\end{array}$ & $\begin{array}{c}140 \\
(18-1100)\end{array}$ & $\begin{array}{c}81 \\
(27-240)\end{array}$ \\
\hline Total & & $\begin{array}{c}13 \\
(10-19)\end{array}$ & $\begin{array}{c}2400 \\
(1800-3600)\end{array}$ & $\begin{array}{c}1500 \\
(1200-2000)\end{array}$ \\
\hline
\end{tabular}




\section{BIBLIOGRAPHY FOR HEALTH AND SAFETY}

Atwood, M. T., L. Goodfellow, and R. K. Kauffman. "Chemical and Physical Properties of 0il Shale Dust and Correlations with Laboratory Fire and Explosivity Test Results," 12 th 0il Shale Symposium Proceedings, Colorado School of Mines, Golden, CO, 1979.

Brown, R., ed. "Health and Environmental Effects of 0il-Shale Technology," Federal Interagency Committee on the Health and Environmental Effects of Energy Technologies, 1979, DOE/HEW/EPA02 MTR-79W00136.

Bureau of Land Management. "Final Environmental Assessment, Colorado Westmorland Coal Lease Adjustment," Bureau of Land Management, Montrose District, CO, 1980.

Cashdollar, K. L., M. Hertzberg, and R. S. Conti. "Explosive Hazards of 0il Shale Dusts: Limits, Pressures, and Ignitability," 17th 0il Shale Symposium Proceedings, Colorado School of Mines, Golden, C0, 1984.

Chappe11, W. R. "The DOE/EV Task Force on the Environinental and Health Effects of Modified In Situ 0il Shale Processes," 12th 0il Shale Symposium Proceedings, Colorado School of Mines, Golden, CO, 1979.

Cho, Paul. "Uil Shale Health and Environmental Effects Rescarch Projects and Risk Analysis Requirements," 17th 0il Shale Symposium Proceedings, Colorado School of Mines, Golden, CU, 1984.

Coomes, R. M. "Carcinogenic Testing of 0il Snale Materials," 12th 0il Shale Symposium Proceedings, Colorado School of Mines, Golden, CU, 1979.

Costello, J. "NIOSH Studies of Oil Shale Workers," lyy.2 tástern U11 Shale Symposium Proceedings, University of Kentucky, Institute for Mining and Minerals Research, Lexington, KY, IMMR82/075, 1984.

Crookston, R. B., and W. N. Hoskins. "Potential for Fires and Explosions in Oil Shale Mining and Processing," lith Uil Stiale Symposium Proceedings, Colorado School of Mines, Golden, Co, 1979.

Drucker, H. "Pacific Northwest Laboratory Annual Report for 1980 to the DOE Assistant Secretary for Environment: Part 1 Biomedical Sciences," Pacific Nortnwest Laboratory, Richland, WA, No. PNL3700 PT1 UC-48. 
Enoch, H. G., J. Lockard, and P. S. Sabharwal. "Eastern U.S. (Devonian) 0il Shale Industry Health Effects Studies," 1981 Eastern 0il Snale Symposium Proceedings, University of Kentucky, Institute for Mining and Minerals Research, Lexington, KY, IMMR82/066, 1983.

Gibson, R. L., and N. K. Weaver. "A Petroleum Industry Program to Evaluate the Health Risks of 0il Shale Materials and Operations," 12th 0il Shale Symposium Proceedings, Colorado School of Mines, Golden, C0, 1978.

Gratt, L. B. "0il Shale Health and Environmental Risk Analysis," 16th 0il Shale Symposium Proceedings, Colorado School of Mines, Golden, CO, 1983.

Gratt, L. B., B. W. Perry, W. M. Marine, and D. A. Savitz. "High Risk Groups in an 0il Shale Work Force," 17th 0il Shale Symposium Proceedings, Colorado School of Mines, Golden, CU, 1984.

Holland, L. M., C. G. Stafford, G. F. Strniste, and M. F. Griffith. "The Los Alamos Integrated 0il Snale Health and Environinental Program: Status Report II," Los Alamos National Laboratory, Los Alamos, NM, 1983, LA-9640-SR.

IWG Corp. "Health and Environmental Effects Document for 0il Shale1981," Health and Environmental Risk Analysis Program, Human Health and Assessment Division, Uffice of Health and Environmental Research, Office of Energy Research, Department of Energy, Washington, DC, 1981, IWG-FR-033-01.

Marine, W. M., D. A. Savitz, L. B. Gratt, and B. W. Perry. "Risk of Dust-Induced Lung Disease in 0il Shale Workers," 17 th 0il Shale Symposium Proceedings, Colorado School of lines, Golden, Co, 1984.

Perry, B. W., and L. B. Gratt. "Public Health Risks frum an 0il Shale Industry," 17th 0il Shale Symposium Proceedings, Colorado School of Mines, Golden, CO, 1984.

"Proceedings of the Symposium on Potential Health and Environmental Effects of Synthetic Fossil Fuel Technologies," First Annual Oak Ridge National Laboratory Life Sciences Symposium, Uak Ridge, TN, September 25-28, 1978, No. CONF-780903.

Richmond, J. K., and F. P. Beitel. "Dust Explosive Hazards Due to Blasting of Uil Shale," 17 th 0il Snale Symposium Proceedings, Colorado School of Mines, Golden, CU, 1984.

Richmond, J. K., M. J. Sapko, L. F. Miller, and L. E. Dalverny. "Explosive Hazards in Gassy and Non-Gassy 0il Snale Mines," 14tn 0il Snale Symposium Proceedings, Colorado School of ilines, Golden, C0, 1981. 
Richmond, J. K., M. J. Sapko, L. F. Miller, A. L. Furno, and L. E. Dalverny. "Fire and Explosive Properties of 0il Shale Part II," 13th 0il Shale Symposium Proceedings, Colorado School of Mines, Golden, C0, 1980.

Sapko, M. J., and J. K. Richmond. "Continuous Monitoring of Methane in a Deep 0il Shale Mine," 15th 0il Shale Symposium Proceedings, Colorado School of Mines, Golden, CU, 1982.

Savitz, D. A., W. M. Marine, L. B. Gratt, and B. W. Perry. "Hydrocarbon-Induced Cancer Risks in 0il Shale Processing," 17th 0il Snale Symposium Proceedings, Colorado School of Mines, Golden, CO, 1984.

Solby, 6., J. Calkins, and H. Enoch. "Detection of Phutumulayens III Eastern Shale 011," 1983 Eastern Uil Shale Symposium Proceedings, University of Kentucky, Institute for Mining and Minerals Research, Lexington, KY, IMMR83/089, 1984.

Selby, C. P., J. Calkins, and H. G. Enoch. "Model Studies of Carcinogenic Properties of Shale 0i1," 1986 Eastern 0il Shale Symposium Proceedings, Kentucky Energy Cabinet Laboratory, Lexington, KY, KECL86-158, 1987.

Taback, H., R. Goldstick, and E. Bates. "The Effect of 0il Shale Recovery Processes on Air Einissions," 19th 0il Shale Symposium Proceedings, Colorado School of Mines, Golden, CU, 1986.

Taylor, R. W., C. J. Morris, and A. K. Burnham. "Nitric 0xide (NO) Emissions from Combustion of Retorted 0il Shale," 18th 0il Snale Sympostum Proceedings, Colorado School of Mines, Golden, Co, 1985.

U.S. Environmental Protection Agency. "Information on Levels of Environmental Noise Requisite to Protect Public Health and Welfare with an Adequate Margin of Safety," Office of Noise Abatement and Control, Washington, DC, 1974.

Vinson, R. P., K. C. $\operatorname{Cox}$, F. N. Kissell. "Methane Encountered at the Bureau of Mines 0il Shale Shaft," 12th 0il Shale Symposium Proceedings, Colorado School of Mines, Golden, C0, 1979.

Weiss, E. S., K. L. Cashdollar, and M. J. Sapko. "Dust and Pressure Generated During Commercial Uil Shale Mine Blasting: Part II," 19th Oil Shale Symposium Proceedings, Colorado School of Mines, Golden, C0, 1986.

Williams, R. E., Z. ZDorovsky, R. M. Blunt, and D. West. "Laboratory and Fire Explosivity Testing of Oil Shale Dust," 12th 0il Shale Symposium Proceedings, Colorado School of Mines, Golden, CO, 1979. 


\section{SOCIOECONOMIC EFFECT by Audie Blevins}

\section{Existing Studies}

Much of the recent socioeconomic research is in the form of Environmental Impact Statements (EISs) written since the passage of NEPA of 1969. Many of the EISs document research conducted in Colorado, Montana, Utah, and Wyoming. Since 1970 there have been over fifty EISs and about a dozen major research reports completed by private companies. Energy From The West, Volume II, provides a comparative case study of six energy impacted or potential impact communities and a regional summary of socioeconomic impacts (EPA). It includes an excellent overview of the impacts that energy related developments have on human welfare in six areas in the west. Particularly valuable is the comparison of baseline (no development) socioeconomic variables with the change that occurs with large scale energy development. Both positive and negative impacts are discussed, focusing on economic, fiscal, social, and quality of life variables.

Similar studies have been made in the eastern oil shale states, but there are fewer and they concentrate primarily on potential developments in Kentucky.

\section{Issues}

Rapid growth resulting from the development of natural resources has raised concern about possible socioeconomic impacts, both positive and negative, for the indigenous population as well as newcomers seeking employment in the developing community.

\section{Community/County Hi story}

An area's history of population growth, particulariy with sudden shifts in rates of growth, appears to influence its ability to adjust to rapid shifts of population growth. Isolated, small communities located in rural, low density areas will have more difficulty in adjusting to 2400 new construction workers and their families than a community of 50,000 located in a more densely populated area (e.g., difference between Wheatland, Wyoming, and Cheyenne, Wyoming). Research by Leistraitz et a1. (1985), Branch et al. (1984), and Thompson and Blevins (1983) documents the need for careful examination of the human context when looking at potential impact from energy development. These variables include demography le.g., size, density, age structure, mobility, and sex/etnnic composition of the population), socioeconomics (e.g., income, education, religion, fami (y), residents' attitudes, and existing infrastructures. Work by Thompson and Blevins (1983) emphasizes the extent to which experience with development affects attitudes towards development and, 1ikewise, the importance of attitudes in determining acceptance or rejection of newcomers into the community. Key research areas related to community history are:

1. demograpnic structure and recent changes in that structure; 
2. existing infrastructure, including services, surplus service capacity, and ability to expand service structure (financial assets, resolve, and skills); and

3. attitudes of locals regarding industrial development, social change, and change in life style.

Growth Management

In the middle 1960s and again after 1973, Campbell county, Wyoming (Gillette), experienced rapid population growth resulting from, first, oil exploration and development and, second, coal development. In both cases Campbell County and Gillette experienced strain on public services (e.g., schools, water, sewage, law enforcement), shortage of housing, and a perceived increase in social pathologies. Work by Kohrs (1974), Blevins and Thompson (1975), and Thompson (1979) discusses aspects of rapid growth or boom town phenomena. Similar boom growth occurred in other western areas, including Rock Springs, Green River, alld Evariston, Wyoining; the west slope of Colorado (Rifle); and Colstrip, Montana. Additional studies document problems in other rapid growth communities similar to those in Campbe11 County (Bacigalupi et a1. 1983; Bender and Stinson 1984; Branch et a1. 1985; Cortese and Jones 1977; England and Albrecht 1984; Freudenberg 1981; Gilmore 1976; Hoffinan 1983; Jobes 1986; Krannich 1981; Massey 1980; Myler 1982; Suminers and Branch 1984).

Gilmore and Dutf (1975), based on the Rock Springs and Green River growth experience, recommend a growth management plan which focuses on pre-development planning, pre-development of infrastructure with an emphasis on front-end funding, and coordination of private and public decision making (Seiple 1974). The key to easing growth impacts is having enough lead time for the community to make necessary structural adjustments that require front-end money which can be obtained either from industry or from the government (Hecox 1983/84; Zillman and Soloman 1983). Numerous researchers (Barry 1981; Davis 1979; LeBus 1984) suggest that one way to obtain the money is the prepayment of taxes by industrial developers (Myler 1982).

Recently, research has begun to focus, at least in the west, on the bust side of population growth: What nappens when a project is completed and a large construction force is replaced by a much smaller operating force, or when development fails to materialize or is terminated because of changes in the market place. A prime example of this boom/bust phenomena is shale development on the culorddu wist slope. After the boom, some towns such as Grand Junction, Battlement Mesa, and Rifle are undergoing substantial economic adjustment as well as having to find ways to utilize and maintain the surplus service capacity of their communities' infrastructure (Marston 1984). For those towns that built public facilities with prepaid taxes and now have declining populations because of declining development, a new and interesting question has arisen: If there is a substantial lag before shale development resumes, who will be responsible for refurbishing and expanding public facilities that were built with prepaid taxes? 
Key research questions for growth management center around the following:

1. financing infrastructure before boom occurs, including federal and state loans (impact assistance funds, mineral severance funds) and prepayment of taxes by prospective developers;

2. social pathologies associated with rapid population growth, including increased divorce, separation, and spouse/child abuse; alcoholism and other drug abuse; increased crime; and increased mental health problems;

3. coordinated participation of the private and public sectors in preplanning for development and rapid population growth;

4. the bust or down side of rapid population growth, including the maintenance of surplus public service capacity;

5. the monitoring of rapid population growth documenting the nature and extent of socioeconomic impacts (the need for before and after studies is vital); and

6. ways of reducing the uncertainty associated with development of energy resources (including start-up of the development, size of labor force, duration of construction, and public participation in decision making).

Labor Force Recruitment and Retention

The plethora of studies (EIAs and EISs) completed since 1970 documents the diversity of construction force estimates and, for some projects, the lack of correspondence between projected peak labor force and actual peak labor force. The lack of good estimators can be attributed to poor projections, good/bad weather, labor issues, or changes in company needs which have to be responsive to market demands. Impacts sometimes are compounded by the presence of multiple industries in the same geographical area and dramatic shifts in construction work time schedule. Hecox (1983/84), Branch et al. (1985), and Leistritz and Murdock (1981) emphasize the need for coordinated planning by the public and multiple developers.

LeBus (1984) and Miller (1982) discuss labor force needs for shale develupmenl within the cuntext of labor availability in the local area. Studies have used capture rates (niring local labor currently unemployed or hiring workers away from other employers) varying from $25 \%$ to $70 \%$. Assuming that hiring locals generates less induced population and therefore fewer impacts on numan services, competition for labor will cause wages to rise, thus benefiting workers but perhaps harming marginal business that cannot pay nigher wages.

Researchers have also separated temporary (construction labor) from permanent labor (operating labor force) in discussing 
socioeconomic impacts. Generally, the construction labor force is much larger than the operating labor force and is thought to create boom/bust types of problems, including temporary peak demands on the community's infrastructure (e.g., schools, medicine, housing, law enforcement, recreation). Furthermore, research indicates that temporary workers have less of a commitment to the local community than permanent workers.

Additional research needed in the area of recruitment and retention of workers centers on the following:

1. ways of improving labor force projections for both construction and operating labor forces (and accompanying induced population);

2. ascertaining the benefits and costs of capturing local labor versus recruiting labor from outside the region;

3. differential impacts of temporary and permanent increases in population on local infrastructure and indigenous population;

4. possibility of coordinating multiple projects in the same locality; and

5. determining the impacts associated with reducing the peak temporary labor force by lengthening the construction period.

Settlement Patterns

Residences for new workers and their families is also a problem. It is possible that development in one county (with the accompanying increased tax evaluation) will cause rapid population growth, strain on community services, and fiscal stress in an adjacent county. Hecox (1983/84), Soloman and Rubin (1985), and Davis (1979) suggest that settlement problems that cross political boundaries can best be solved by a regional approach involving legal and fiscal planning geared to the impact area rather than to municipal, county, or state boundaries. A regional approach would take into account spillover effects of single or multiple projects and would promote an equitable distribution of costs and benefits of shale development. One approach to regional planning is the gravity model (Murdock and Leistritz 1978) that predicts population settlement patterns around a given development. It takes into account the size of the influx, existing population densities, distribution of population around the project site, and differential opportunity structures in the project area.

Areas that need additional research include the following:

1. feasibility of regional planning, fiscal policy, and legal regulation of shale development and its impacts on human services; 
2. additional testing of settlement patterns around project sites; and

3. the extent of existing spillover effects of shale development.

Quality of Life Issues

Numerous researchers have addressed the problem of deterioration of quality of life (perception of social relationships as well as decline in public services) and come to different conclusions. Wilkinson et al. (1982) raise serious questions regarding the deterioration of the community or social disruption caused by large population increases, while Jobes (1986) found that Ashland; Montana, experienced substantial increases in alienation and out migration of natives. England and Albrecnt's study (1984) of Craig and Gunnison, Colorado, and Price, Utah, found little support for social disruption or for the decline of social relationship hypothesis, but did find an across-the-board decline in social services. Finsterbusch (1985) and Branch et al. (1985) note the need for more research on both the positive and negative impacts of rapid growth on rural communities, focusing on developing indicators of well-being which would be monitored for the duration of project or at least until project employment leveled off.

Related to quality of 1 ife issues is public participation in the planning and permitting process. Most state statutes mandate public hearings (Appendix A) and encourage public participation. Finsterbusch (1985) suggests that public participation may relieve feelings of uncertainty about proposed energy developments and positively impact attitudes about development.

New research regarding quality of life issues centers around the following areas:

1. quantification of qualitative feelings, attitudes, and beliefs;

2. impact of public hearings on community attitudes toward proposed developments;

3. positive aspects of community growth and social change (e.g., diffusion of new ideas, organizations and soclal relationships);

4. empirical examination of the social disruption nypothesis; and

5. examination of public services most likely to experience impact and change, such as recreation, as when individual recreation is reduced (8.g., hunting, fishing, and camping) and organized recreation expands (e.g., softbal1, soccer, and ice nockey). 
In 1969 the National Environmental Policy Act established the requirement that Environmental Impact Statements (EISs) be completed for developments involving federal agencies (1and, permits, or regulation). In very broad language, this act requires that the social and economic requirements of citizens be addressed in the EIS and that the EIS must include the integrated use of the natural and social sciences in making decisions that might have an impact on man's environment. Because of this general mandate, a number of books, monographs, and articles have been published since 1970 describing how to conduct a satisfactory socioeconomic assessment of proposed industrial development. Some writers attempted to integrate social science theories of economic cost benefit analysis, community, social organizations, demography, and social change, while others published "now to do a socioeconomic assessment" handbooks (Moore et a1. 1983; Grimes et a1. 1984; Death 1982; Burdge and Opryszek 1983; Leistritz and Murdock 1981; Branch et a1. 1984; Department of Interior 1983: DeSouza 1979). More recently, computer-based models have been developed to assist in writing socioeconomic assessments, including computerized projections of economic, fiscal, and social impacts of proposed developments of any size with varying construction and operation schedules.

\section{Socioeconomic Models}

Socioeconomic research on the impact of shale development has been concerned primarily with the changes that indigenous populations experience when their numbers expand rapidiy as a result of a large influx of iminigrants seeking employment. It is generally assumed that the types of social changes that occur are dependent on the nistory of the colimunity, its social organization, its population structure, and its economic base. The nature of the impact, temporary or permanent workers and duration of peak influx, is also considered. Recently, research has focused on impacts on newcomers.

Efforts to model the above factors have concentrated on several areas of social change which require submodels or modules (e.g., economic module, demographic module, social module, public services inodule, fiscal module). Models may develop the underlying rationale for including variables and relationships between variables or provide a step-by-step "how to do a socioeconomic impact assessment."

Leistritz and Murdock (1981) provide a standard socioeconomic model and rationale for writing socioeconomic impact assessments. It consists of five modules, each with subcomponents. Similar to the Leistritz/Murdock model is the Simpact system designed by DeSouza (1979). He described four models: the economic and demographic model, the planning model, the fiscal model, and the environmental mode1. As did Leistritz and Murdock, DeSouza emphasizes the need to specify, paramaterize, and operationalize variables. Simpact is specifically designed for computerization. Another model is restricted to social organization (though including most of the above components) and combines analytical and practical aspects of examining social impact assessments (Branch et al. 1984). 
Leistritz and Murdock begin with an economic module based on export base theory (basic and non-basic employment), location theory (why firms choose a particular location for their plant), and central place theory (locates the center of greatest population growth and the radiating influence of population growth). DeSouza also focuses on production but refers to production components as primary (scope of the proposed facility's activities upon which employment depends) and secondary inputs which are separated into supplier production for the primary facility, indirect production with changes brought about by supplier purchases in the local area, and induced production due to consumption expenditures of primary employees, supplier employees and indirect employees.

Input/output is discussed as an alternative economic module described by Leistritz and Murdock. Crucial to either economic module is the availability of regional data as well as accurate information on the local labor force and labor force requirements of the proposed shale development. Problems in data accuracy and availability lead to uncertainty which increases the model's tendency to make errors in prediction (Stenehjem and Metzer 1976).

Leistritz/Murdock (1981) discuss five demographic projection techniques: extrapolative (curve-fitting and regression-based), ratio-based, 1 and use, economic-based, and the cohort component method (Lee and Goldsmitn 1982; Bogue 1974). The latter provides a large volume of information in great detail; nowever, it is expensive and time consuming to use. Factors included in the demographic module are plant location, direct project employment, indirect/direct worker ratios (multipliers), length of project phases, levels of local hiring (capture rates), and developer's employment practices. Al so relevant are assumptions about settlement patterns of newcomers and matches between labor force characteristics required by the development and characteristics of the local labor force. Since the economic module drives the mode1, the demographic module needs information regarding the number of new jois created. The key to successfur denographic projection is developing accurate relationships between the number of new workers and number of dependents (multipliers), and then establisning reasonable settlement patterns for newcomers.

Public Service Impact modules usualiy take one of two approaches. One (average unit approach) takes into account only the new population, and another (marginal unit approach) takes into consideration the existing infrastructure and population. The average unit approach estimates public services per 1000 new population, while the marginal unit approach starts with existing services and seeks to determine the differential relative need for each unit of increase which is dependent on the increase in population but not in a linear fashion. One key issue in puilic service modelling is whether to use local, state, regional, or national standards for public service capacity or delivery. Public services usually include police, fire protection, sewage, water treatment, sanitary land fill, nealth, recreation, education, and social services (assistance); for each service, the local capacity, quality of facility/service, and its distribution must be determined. Also, the local population's 
perception of the service needs to be incorporated. In his community Planning Mode1, Desouza (1979) includes both public infrastructure (public services) and private infrastructure (homes, apartments, motels, factories, offices, and stores associated with in-migrating and secondary workers).

The Fiscal Impact Module projects changes in costs and revenues of local governments (public sector) when rapid growth occurs. Public services are goods owned by the public and are subject to political decisions which are subject to constituent pressure; consequentiy, supply and demand are subject to interest group pressure (Branch et a1. 1984). Accurate fiscal impact modelling is dependent on detailed knowledge of the local environment/characteristics. Generally, the supply of services is reduced to capital and operating costs (also average and marginal costs). Revenues refer to monies raised locally (e.g., user fees, property taxes, sales taxes) or to funds that cross levels of government le.g., mineral trust funds, community development funds). The key to accurate predictions by the fiscal module is the time lag between obtaining resources and incurring costs, nence the importance of the construction of operation schedule. Another important area is the distribution of costs and revenues. The spillover of impacts into adjacent counties/communities that receive no increase in taxable property emphasizes the jurisdictional problems of cost/revenue distribution and poses a serious drawback for fiscal modelling.

Leistritz and Murdock (1981) suggest that problems in social impact modules lie in the poor operationalization of "soctal impact variables" (e.g., patterns of social interaction, furmal and informal relationships, and perceptions of community and social change). The social impact module requires information from the local community and generally involves survey research, participant observation, and unobtrusive measures (e.g., newspapers, records of public meetings). Once data are acquired, social impact assessment modules rely on trend extrapolation techniques, expert opinion (delphi surveys), value forecasting procedures, social changes and development theories, and/or scenario forecasting technqques (Leistritz and Murdock 1981) to project social impacts.

Social impact modelling requires interfacing various modules. Generally, the economic or economic and demographic modules deterinine the values of the remaining modules (public services, fiscal, and social). Successful modelling relies on the development of accurate baseline information about the local community/county before development and then projects changes in social variables that would occur with developments of varying size and time schedules. This dependence on sufficient, accurate data increases the costs of models and requires experts to assist local planners; nowever, the requirements of socioeconomic impact assessment can be easily built into the EIS process.

The Draft Environmental Impact Statement (1983) prepared by the Bureau of Land Management provides a general, integrated model in which socioeconomic analyses are provided for air quality, water 
resources, visual resources, cultural resources, mineral resources, paleontology, and transportation services. However, socioeconomic issues are limited as well as in depth. On the positive side, socioeconomic issues can be viewed within the context of different policy approaches, including oil shale development, no development, program alternatives consisting of different levels of development, energy conservation, and alternative fuels. Yet, it can only provide broad policy guides, not the depth needed for the socioeconomic component of an EIS. A much more in-depth treatment is in the three volumes of Energy from the West (EPA) which examines the social, economic, and political impacts of energy development of varying labor intensity, capital intensity, and scheduling.

Branch et al. (1984) provide a useful bridge between the theoretical/analytical models of DeSouza and Leistritz/Murdock and the practical handbook approaches. The Sociali Organization Model (SOM) has a substantial introduction to the social impact assessment process followed by a detailed analytical/practical treatment of the assessment framework and concludes with detailed information on how to obtain quality social/economic data.

A great deal of their analysis focuses on the ability of $a$. community to adjust to rapid social change generated by influx of newcomers without a significant deterioration of quality of 1 ife. Inherent in the SMO is the contribution of decision-makers in planning the model, particularly in identifying problems. It is based on four components: direct project inputs (similar to economic/ demographic modules), community resources (community history, population, labor force infrastructure, and fiscal module), community social. organization, and indicators of well-being (rates of behavior such as suicide, crime, and family violence; access to resources such as income, pubic services, and recreation; and perceptions of community and personal well-being--the social modules). Project inputs are seen as having reciprocal relationships with the other tinree components that are characterized by uncertainty.

Furthermore, the SMO maintains that residents are not passive; to the contrary, they are active in accepting, altering, or rejecting proposed project inputs.. They are also active in enhancing their own position relative to others (oldtimers and newcorners). The SMO portrays a dynamic community with individuals and the organization as constantly posturing for scarce resources.

\section{Computer-Based Socioeconomic Models}

Most socioeconomic computer models have been developed since 1960. One of the first was the Susquehanna River Basin Model (Leistritz and Murdock 1981) wnich integrated economic and demographic sectors. It used aggregated data and was applicable at a regional 1evel. By the early 1970s, there were nalf-a-dozen similar regional models, each professing some advantages over its predecessor either in time period of projection, greater detail of projections, or in availability of disaggregated and aggregated projections. All models were the mainframe variety (requiring substantial computing 
facilities). Models developed by the late 1970s and early 1980s can make projections for smaller units of analysis (county, municipality, or school district), for a greater number of projection categories, and for rapid changes in input, thus providing projections for short periods of time.

Currently, numerous computerized socioeconomic models are available. The Reference Guide to Social and Economic Techniques (Allen et al. 1982) lists computer inodels, authors, location of models, and brief descriptions of the models' capabilities. For example, the MSU Economic/Demographic Computer Model contains four modules: an input/output module, a conort survival module, a residential allocation module, and a fiscal impact module. The contact person is Loren Cabe, Montana State office, Billings, Montana. The Reference Guide contains information on about a dozen similar projection models. Leistritz and Murdock (1981) also provide a summary of computer projection models. Their discussion includes content of the model (the number of component modules) and a brief discussion on how the model works. An analysis of 13 models developed since 1975 which were designed to be used at the county or subcounty level is provided. Models discussed include ATOM-3, BOOM-1, BREAM, CLIPS, CREIO, HARC, MULTIREGION, NAVAHO, NEW MEXICU, RED, SEAM, SIMPACT, and WEST. Evaluation of the 13 models is based on their informational characteristics (number of impact categories included), methodological characteristics (variable relationships within modules and relationships across modules), and use characteristics (input and computer requirements).

Computer projection models enable the researcher to provide specific as well as timely answers. Furthermore, as conditions of construction change, most computer models can rapidly provide changed scenarios of socioeconomic impact. For example, the peak construction labor force might shift from 1800 to 2600 because of a compressed construction schedule. Computer projection models would ideally be used to predict changes in school enrollment; shifts in fiscal assets/liabilities; and additional demands on public services such as water, sewage, garbage, fire protection, law enforcenent, and rccrcation. The timeliness of such projections can be helpful in planning for rapid growth; yet, these models are onty as good as their underlying assumptions (e.g., specified relationships between variables, multipliers to be used to estimate induced population for each construction or operating job created, impacts per 100 induced population) and the quality of the data. Computer model selection should be based on needs such as detail of information, location of project, and time scheduling of resource development. Leistritz and Murdock (1981) suggest that, at a minimum, "information on the economic, demographic, public service, fiscal and social changes likely to occur under both baseline and impact conditions for both construction and operational phases" should be included. Uf course, the bottom line in selecting a projection model is accuracy, the ability to predict baseline and impact conditions. 


\section{Data Gaps}

The greatest data gaps for future impact assessment of shale development are in conceptual and analytical refinement, especially with the interface of different socioeconomic impact modules. The quantification of variables and the interfacing of qualitative research with quantitative research needs attention, particularly in measuring changes in quality of life. Areas where additional research is needed are listed below:

1. how social/economic structures change as a result of major economic or population growth;

2. what factors determine migration and settlement decisions;

3. how rural service structures respond to increased demands;

4. now taxation will be applied during a period of rapid development (the political context of revenues/costs);

5. now newcomers and oldtimers will perceive impact;

6. how the development of a set of growth alternatives (rather than action and no action alternatives) and projections relates to impacts on human welfare;

7. what Denefits occur from development;

8. how political planning is conducted;

9. whether the project is modified;

10. monitoring (what, how often, whose responsibility, and utilization for mitigation); and

11. feasibility of new towns for mitigating socioeconomic impacts of large scale shale development. 


\section{IMPACTS - DATA GAPS}

Summary

In general, the extent of environmental impact caused by an oil shale industry is directly correlated with the size of industry, the management techniques employed, and the resultant population and commercial growth. It is important to note that other industries will probably be developing in the same general area (especially in the West). The cumulative impacts of several industries developing simultaneously could be detrimentally synergistic, and this should be considered when evaluating the feasibility of an oil shale project.

Data gaps and research needs for oil shale development cover seven areas: (1) wastes, (2) spent shale piles, (3) air, (4) water, (5) health and safety, (6) ecology, and (7) ecosystem.

\section{Hastes}

Solid, liquid, and gaseous effluent compositions are sensitive to variations in retorting conditions. Likewise, the leachate composition of groundwater and surface water in contact with spent shale is directiy related to the chemical and inineralogic reactions that occur in shale during the retorting process. The correlations between (1) retorting conditions and effluent compositions and (2) leachate composition and chemical/minerological reactions are not yet understood.

\section{Snale Disposal Piles}

Very little research has been condurter on shale disposal piles, i.e., processing, management, engineering, operating scenarios, and shale disposal embankments on the environment.

Air

Gaseous effluent transport, chemistry, and quality are significant research concerns. Meteorology of site-specific areas needs to be determined before transport of effluents can be assessed. Atmospheric conditions vary considerably between the eastern and western sections of the country. According to regulation, air quality effects must be predicted for nearby park and wilderness areas. Another area needing research is acid deposition in western 1akes.

\section{Mater}

Water quality will be affected by an oil shale industry, especially in the arid west where the greatest reserves of oil shale exist. However, the manner in which water effluents, leaching of spent shale piles, erosion, and runoff will affect water quality is not well understood. 


\section{Health}

Health and safety impacts to workers can be readily ascertained by extrapolating information from the petroleum to the oil shale industry. How potential groundwater and surface water pollutants will behave mutagenically and teratogenically, and their toxicity to the general public, are unknown.

\section{Ecology}

Cumulative ecological impacts include deposition, direct and indirect effects of pollutants, and synergistic effects of multiple pollutants. An example of synergism is the combination of low levels of sulfur dioxide and nitrogen dioxide or ozone. This combination is more environmentally detrimental than exclusive pollutants.

\section{Ecosystem}

The final area of consideration is ecosystem response. This data gap is site specific. For each lease site, now damage to any indicator species of flora and fauna will affect the overall nealth of the ecosystem needs to be determined prior to development. How the ecosystem will recover following reclamation of a site must also be estimated.

\section{Summary}

Most data gaps and research needs are a result of non-commercial production of oil shale. Unfortunately, until more field research is conducted, only superficial estimates of potential nazards can be made. 


\section{BIBLIOGRAPHY FOR DATA GAPS AND RESEARCH NEEDS}

Bartke, T. C. "U.S. Department of Energy 0il Shale Program Funded Research/Projects," 1986 Eastern 0i1 Shale Symposium, Kentucky Energy Cabinet, Lexington, KY, RECL86-158, 1987.

Los Alamos National Laboratory. "A Strategic Plan for $0 i 1$ Snale Siting Research," Los Alamos, NM, November 1985.

Pfeffer, F. M. "Pollution Problems and Research Needs for an 0il Shale Industry," U.S. Environmental Protectión Agency, Environmental Research Laboratory, Ada, OK, EPA-660/2-74-067, 1974.

Willard, D. E., I. W. Ritchie, and M. R. Stork. "Information Gaps for Siting Uil Shale Development in Indiana," 1985 Eastern 0il Shale Symposium, Kentucky Energy Cabinet, Lexington, KY, RECL/85-147, 1986. 


\section{EXAMPLES OF RESEARCH NEEDS}

HATER QUALITY

1. What are the most feasible methods for disposing of brines and other residues and still protect surface water and groundwater?
a. Which sites are suitable for deep well injection of brines and other liquid concentrates?
b. What sites are suitable for evaporation and/or landfill of concentrates?
c. Can brines and other residues be converted to usable by- products at some sites?
d. Is it possible to slowly bleed brines into surface waters at some sites?

2. Which sites are suitable for in situ and modified in situ oil shale processing? How can groundwater be protected during development and after retort abandonment?

3. How can ecosystem recovery best be monitored and accomplished? Indicator species of sensitive flora and fauna need to be determined prior to development.

4. What effect will oil shale development have on acid rain? 


\section{LOSS OF RESOURCE \\ by John Nordin}

Loss of resource is defined as a resource made unavailable for use because of oil shale development. This discussion is limited to loss-of-water resources and loss-of-shale resources.

\section{Hater Resources}

Loss-of-water resources occur because brines and other pollutants released to the environment render the water unfit for other purposes. Salts released as a result of development in the western U.S. (Colorado, Utah, Wyoning) eventually are routed to the Colorado Rivor. Salinity in the coloradn River is of concern for irrigation projects and the Yuma, Arizona, water desalination project. The U.S. has a treaty with Mexico to supply a certain amount of low salinity Colorado River water. Salinity released to eastern rivers impacts drinking water supplies.

The EISs developed for projects in colorado, Utan, and Wyoming show a zero or near zero discharge of wastewater. Brines and other polluted wastewaters are routed to evaporation ponds, are used for moisturizing spent shale, or are used for dust control. Groundwater withdrawn for shale oil processing or which fills an in situ retort cavity or a inine inay be brackish before development. For example, the high saline content of the retort water periodically pumped out of the old in situ retort cavity at Rio Blanco appears to be caused by aquifer penetration and not by the retorting process. EISs also do not consider the gradual leaching of dissolved solids from spent shale piles or abandoned evaporation ponds. Leachate studies reported in the literature usually consider only certain toxic metals and organics and do not consider the general effect of salinity.

The withdrawal of surface water and groundwater is also a loss of resource. The withdrawal of surface water is restricted by water rights legislation. The issue is not that the water is lost but that the protection of water supplies against contamination, including salinity, increases.

\section{Dil Shale Resources}

Western Research Institute has been unable to find a definitive study where this subject is addressed. Data in the literature estimate that shale can be recovered by underground mining with up to 60\% recovery. Spent shale and overburden placed on top of unmined shale deposits may render the deposits unsuitable for future recovery. Other estimates on recoverable shale oil make gross generalizations, such as $10 \%$ or $20 \%$ of the in-place deposit recovered, but do not conduct a systematic analysis to determine actual loss of resource. This topic needs to be addressed. 


\section{Data Gaps and Research Meeds}

1. Research needs to determine how much surface water can be withdrawn in the shale areas in Colorado, Utah, and Wyoming to support shale oil projects, assuming a near. $100 \%$ recycle of water. Water resources in the Piceance Creek Basin should be surveyed.

2. Research needs to determine the fate of brines and other water soluble residues resulting from oil shale retorting and to develop control technology for protection of water supplies.

3. A realistic, systematic determination of recoverable oil shale resources needs to be developed for loss of resource. 
PHASE 5. PROPOSED RESEARCH 
Western Research Institute (WRI) proposes a number of research areas to be addressed. The list. is not intended to be all inclusive. Several of the proposed topics could be completed in a year's time with a $\$ 100,000$ budget each. Others will require greater resources.

\section{Flow Chart for oil Shale Development}

WRI proposes to develop a research plan and flow chart for oil shale development with emphasis on complying with institutional restrictions.

The research plan will consist of the following steps:

1. Update the permit information system for shale oil which was originally done under contract with Science Applications, Inc., in 1979, DOE contract 31-109-38-3764, and expand it to the eastern states. The update has been completed for colorado, Wyoming, Utan, Kentucky, Indiana, and Unio, and has been included in this report.

2. Expand the permit information system to include water rights and specific permits for the Bureau of Land Management, Indian Lands, and air quality permits for non-attainment areas.

3. Discuss time required to obtain permits and negotiate with various agencies.

4. Summarize the information in the forin of a flow chart for oil shale development.

\section{Siting Plan for Small Demonstration Shale Uil Plant}

WRI proposes to develop a siting plan for a demonstration share oil plant. possioly $5000 \mathrm{bbl} /$ day capacity, in a state to be selected. The plant will be constructed so that it can be disassembled and transported to a new location.

The siting plan consists of the following steps:

1. identify resources within the state or geographical area (e.g.. New Albany snale);

2. identify specific restrictions on developing the resource, including permits needed to complete the project;

3. identify candidate process technologies suitable for the demonstration plant and select one;

4. develop an outline for an environmental impact statement for several candidate locations; and 
5. complete an EIS for one technology at a specific location, including a plan for retort abandonment and restoration of the site.

\section{Resource Recovery}

WRI proposes to determine the amount of shale oil that can be recovered in selected locations if all of the resource is developed.

The research plan is as follows:

1. select a particular geographical location for review;

2. determine the type of in situ oil shale available in the area, preferably from reports describing core borings; categorize the information on overburden, thickness, Fischer assay, carbon content, and other parameters;

3. identify and eliminate resources not available for development because of existing urban population, designated wilderness areas and parks, unsuitability for development because of rivers or other geological features, nabitat for endangered species, known locations of archaeological and nistorical importance, 500-year floodplains, wetlands, recharge zones of designated sole source aquifers, or active fault zones;

4. identify process technologies suitable for development on a site-specific basis; and

5. determine the loss of resource associated with development.

This exercise assumes that all of the necessary permits including water rights will be obtained and that all of the resource is developed with the exception of those specifically eliminated from consideration under part 3.

\section{Hater Resources of Piceance Creek Basin}

WRI proposes to complete an in-depth study of one of the topics relating to siting methodology. An example might be to survey and update water resource information in the Piceance Creek Basin, including both surface water and groundwater supplies.

The study plan is as follows:

1. survey published information on water resources in the Piceance Creek Basin;

2. catalog and copy relevant information at the Denver Federal Center, Bldg 50, BLM file; BLM files in Craig County; and the BLM file in Vernal, Utah. The U.S. Geological Survey, Denver Federal Center, is another source of information (John Dyni); 
3. contact people familiar with the subject, e.g., Jim Taylor, retired, (303) 236-4886; Glen Miller, water monitoring, retired; Bob Tobin, Meeker, water resources, (303) 878-5086; Don Coffman, water resources, (303) 235-5920;

4. identify specific locations in the Piceance Creek Basin where water resources are not well-known;

5. discuss the effects of water resources on shale oil development, including modified in situ retorting; and

6. discuss the impacts of shale oil development on water resources.

The following areas may require more than one year for WRI to conduct research completely:

\section{Disposal of Brines and Residues}

WRI proposes to evaluate the processes for ultimate disposal of brines and solid residues from surface retorting operations throughout the country. Residues include retort process water brines and sludges, air scrubber brines and sludges, solids that leach significant salts and/or toxic materials, and evaporation pond residues. Residues not included are overburden, unretorted shale, spent shale, sewage treatment plant sludges, and spent catalysts.

The Research Plan includes the following:

1. complete a literature review on oil production brine disposal and on storage of brines and residues in evaporation ponds;

2. determine the feasibility of deep well injection of brines in oil shale areas in the eastern and western U.S.;

3. determine pretreatinent for brines and other residues prior to deep well injection; verify by bench scale treatability tests; and

4. explore potential for useful by-products from brines and other solid residues (e.g., ammonia can be steam stripped from retort water and collected with condensate and used as a fertilizerl.

\section{In Situ and Modified In Situ Retorting}

WRI proposes to determine oil snale locations suitable for in situ and modified in situ retorting and to develop a procedure for minimizing contamination of groundwater. 
The Research Plan includes the following:

1. complete a literature review of prior work on in situ and modified in situ retorting;

2. gather and analyze information on retort abandonment, e.g., Rio Blanco case nistory;

3. survey underground water resources, water-bearing strata at sites winich might have shale resources suitable for in situ retorting;

4. compare in situ retorting between the eastern and western U.S.;

5. describe the site conditions for which in situ or moditiod in situ retorting may be conducive;

6. develop a plan for minimizing contamination of groundwater; and

7. develop a plan for groundwater and site restoration.

\section{Processing Rich Shale}

WRI proposes to survey the problems associated with processing rich (greater than $30 \mathrm{gpt}$ ) shale and to develop a procedure for successful processing.

The Research Plan includes the following:

1. survey the literature on locations, depth, and characteristics of rich shale; rich shale deposits are known in the Mahogany Zone in the Piceance Creek Basin and in Alaska;

2. document problems associated with processing rich shale (e.g.. heavy hydrocarbon load in upper part of Paraho retort surface processing; in situ processing of rich shale may result in subsidence because the retorted shale cannot physically support the shale above it);

3. set up a series of experiments designed to understand the mechanisms by which rich shale causes problems in the retort; and

4. develop procedures for processing rich snale (e.g., blend rich shale with lean shale before retorting; mine rich shale for surface retorting before any in situ retorting). 


\section{Ecosystem Baseline Studies and Restoration}

WRI proposes to define ecosystem baseline conditions at a location where shale oil can potentially be developed and to define the conditions for ecosystem recovery if that location is chosen.

The Research Plan includes the following:

1. select a definite location or area for study;

2. review prior studies on ecosystem baseline conditions;

3. identify indicator species (e.g., animals, plants, invertebrates) by which the health of the ecosystem can be monitored;

4. identify how damage to sensitive plants, animals, and invertebrates affects the health of the ecosystem;

5. consider the natural variability of the ecosystem (e.g., precipitation) so that significant changes due to oil shale development can be unambiguously identified;

6. review prior studies on revegetation of mined areas and ecosystem recovery;

7. inventory plants, animals, and selected invertebrates in areas which have undergone shale or coal surface mining and have been restored and compare this with information from undisturbed areas; and

8. define conditions for improving top soils and for revegetation of restored areas previously surface mined. 


\section{APPEMDIX A}

LIST OF STATE STATUTES 


\section{Appendix A: List of State Statutes}

Generally, the oil shale states have few if any statutes specifically for socioeconomic issues related to oil shale development. Statutes that are in effect are related to energy development in general or to facility siting of large scale industrial development such as a coal mine or power generation station. Each state was contacted by telephone and asked whether their statutes addressed socioeconomic issues related to oil shale development. In I most cases the answer was negative. They were also asked whether their state statutes regulated mining or large scale siting of industries and, if so, to send. a copy. These regulations were examined for relevance to socioeconomic issues connected with mining or siting. Listed below are those statutes deemed appropriate and the title of the contact office or person for each state.

\section{COLORADO}

Department of Natural Resources

Mined Land Reclamation Board

Regulations for Coal Mining (2 CCR 407-2)

2.02.3 General Requirements: Exploration Involving Removal of ilore than 250 Tons of Coal.

(1)(c)(i) Narrative description of physical features including: historic sites, buildings, structures, objects, etc.... (e) Map of area including cultural "features," access routes and historic features.

(2)(a) Public posting on notice, (b) Content of public notice. (c) Rights of those who may be adversely affected by the proposed facility.

2.02.4 Applications: Approval or Disapproval of Exploration Involving Removal of More than 250 Tons of Coal.

(3)(c) Pronibiting damage to cultural resources, sites, buildings, structures or objects listed on the National Register of Historic Places.

2.03.7 Relationship to Areas Designated Unsuitable for Mining.

(3) Waiver obtained from landowners within 300 feet of the surface mine.

2.04.3 General Requirements: Site Description and Land Use Information.

$(2)(b)(i)$ Land use capabilities before mining. Assessment of the land's productivity.

2.04.4 Cultural and Historic Resource Information. List and description of the cultural and nistoric resources and archaeological sites.

2.04.12 Prime Farmland Investigation. Assessment of proposed sites in terms of threat to prime farmland. 
2.05.3 Uperation Plan--Permit Area.

(3)(D)(i)(C) Approximate dates on which construction of the existing structure was begun and completed. $(c)(v)$ Measures to ensure the interests of the public and landowners.

2.05.6(4) Protection of Public Parks and Historic Places.

2.05.6(6) (e)(ii)(B) Subsistence damage to renewable resource lands and aquifers expressed in terms of food, fiber, or forage, to the level it would be if subsidence had not occurred.

2.06.2(9) Protection of Environment and Public Safety from Experimental Mining Practices.

2.06.3(3)(a) Postmining use of Mountaintop Land.

2.06.5 Applies to non-mountaintop removal steep slope surface coal mining and reclamation operations. (20)(b) Proposed use will constitute an equal or better economic or public use.

$2.06 .8(5)(a)(i)(I)$ Provides that mining operation does not interrupt, discontinue, or preclude farming on an alluvial valley floor.

\section{Colorado 0il Shale Statutes}

$25-8-502 ; 29-20-101$ to $107 ; 34-2-103 ; 34-33-103 ; 34-63-104 ; 36-1-103$; $36-1-140 ; \quad 39-3-112 ; \quad 39-22-110 ; \quad 39-29-102 ; \quad 39-29-107$; 39-29-107.5; $39-29-108$; 39-29-110; 39-29-111; and 39-29-112.

\section{INDIANA}

Department of Natural Resources

James M. Ridenour, Director

Guidelines Respecting the Administration of an Act Regulating Surface Mining of Coal, Clay, and Shale.

This document is exclusively concerned with physical reclamation of a mining site. Its only reference to socioeconomic impacts is the possipilịty that a reclaimed "grade" may be used for "nousing." Some penalties for abrogating the statutes are listed.

Contents: (1) Introduction, (2) Guidelines, (3) Listing of Forms, (4) Instructions for Completing Forms, (5) Standards for Surface Mine Grading, (6) Standards for Access Roads-Fire Lanes, (7) Application for Construction in a Floodway, and (8) Indiana code 13-4-6, as amended.

\section{KENTUCKY}

Department for Surface Mining Reclamation and Enforcenent Natural Resources and Environmental Protection Cabinet Commonwealth of Kentucky 
Regulations for 0il Snale Operations 1983

405 KAR Chapter 30: 0il Snale Regulations

Ecological, nistoric, archaeological, health and safety, and farmland use considerations are treated periodically throughout the document, but socioeconomic issues per se are not addressed.

Some areas of possible interest are:

pg. 090-02, any person may "cause an inspection" of a mine site for the purposes of making sure the regulations are obeyed.

pg. 110-01, allowance is made for public participation in inspection and enforcement.

pg. 240-02, (K) greenbelts are required in reclaiming "residential, public service, or industrial land use."

\section{OHIO}

Unio Mining and Reclamation Rules

1501:13-1-02(D) Adjacent area--area outside of immediate facility, which could reasonably expect to be impacted by the mine: (E) Affected area--land or water upon which the mine is located. (P) Cropland (R) Developed Spring--a spring regularly being used for agricultural or domestic purposes. (EE) Historically used for cropland five or more years. (HH) Imminent danger to the healtin and safety of the public. (VV) Person having an interest--valid legal. (YY) Prime farmiand. (AAA) Public roadway. (LLL) Significant, imminent environmental harm to 1and, air, or water resources.

1501:13-1-09. Notice of Citizen Suits--civil action concerning alleged violation of these rules.

1501:13-1-12. Notice of public nearing to adopt, amend, or rescind rules.

1501:13-2-02. C permits--general map requirements.

1501:13-2-03. $\quad C$ permits--application maps and amendment maps ( $P$ ) counties, municipal corporations, property boundaries.

1501:13-2-10(E)(1) Permanent diversion structures--public health and safety. (L)(4) Public water supplies. Water rights and replacement.

1501:13-2-12(7) Blasting--prescribed distances and circumstances. 1501:13-2-16c Permits--postmining use of land. (c)(1)(b) Retail or trade of goods or services.

1501:13-2-21C Permits--mountaintop removal (A)(1) Industrial, commercial, agricultural, residential, or public facility for use after mining: 
$1501: 13-3-02$

$1501: 13-3-03$

$1501: 13-3-05$

$1501: 13-3-07$

$1501: 13-4-01$

$1501: 13-4-04$

$1501: 13-4-05$

$1501: 13-4-08$

$1501: 13-4-12$

$1501: 13-4-13$

$1501: 13-4-14$

1501:13-5-01
Definitions. dwelling. building. Cemetery.

Areas where mining is prohibited or limited. Criteria for designating areas unsuitable for coal mining operations. (2) Historic lands.

Procedures for designating areas unsuitable for coal mining operations.

General requirements for permit and exploration procedure systems. (I)(2)(b) Statement of names and addresses of those supplying information for purposes of compliance with these rules.

Perinit application requirements for information on environmental resources, (A) (2) Cultural and historic resources. (I)(2) Location of all buildings on and within one thousand feet of the proposed permit areas.

Permit application requirements for reclamation ana operations plans. (B)(2)(d) Risk of harm to environment or public health or safety during modification or reconstruction. (I) Protection of public parks and historic places. (J) Relocation or use of public roads.

Hydrologic map and cross sections. (A) (3) Al 1 occupied buildings on or within one thousand feet of the proposed permit area.

Requirements for permits for special categories of mining. $(B)(3)(d)(11)$ Experimental practice w111 not reduce the protection afforded public health and safet.y. $(E)(1)(b)$ Equal or Detter economic or public use.

Underground mining permit application requirements for information on environmental resources. (D) (C) known uses of the water in the aquifers and water table. (F) Alternative water supply information. (I) Maps (2) (5)(5)(7)(8)(9).

Underground mining permit application requirements for reclamation and operations plans. $(B)(2)(d)$ Risk of harm to environment or to public healtin or safety is not significant during the "reconstruction." (H) Protection of public parks and nistoric places. (I) Relocation or use of public roads.

Review, public participation, and approval or disapproval of permit applications and permit terms and conditions. (B)(D)(D)(i) Description of surrounding area which will allow for ready identification of the proposed permit area. (D) Right to file objections. (E)(2)(d) Acceptance of information/evidence during an informal conference. (H)(5) The proposed operations will not adversely affect any publicly owned pariks or places in the National Register of nistorical places. $(I)(1)(a)(i i)$ Harm to the public or environment. 


\begin{tabular}{|c|c|}
\hline $1501: 13-7-05$ & $\begin{array}{l}\text { Procedures, criteria, and schedule for release of } \\
\text { performance bond. (A) ( } 6)(a)(i i)(a) \text { Jurisdiction or } \\
\text { expertise with respect to any environmental, social, } \\
\text { or economic impact involved in the operation. }\end{array}$ \\
\hline $1501: 13-7-06$ & $\begin{array}{l}\text { Performance bond forfeiture criteria and } \\
\text { procedures. (E) Responsibility of compliance. }\end{array}$ \\
\hline $\begin{array}{l}1501: 13-7-07 \\
1501: 13-9-06\end{array}$ & $\begin{array}{l}\text { Liability insurance--public. } \\
\text { Use of explosives. (E)(6) Blasting within one-half } \\
\text { mile of any public or private institution. } \\
\text { Maximum ground vibration. }\end{array}$ \\
\hline $1501: 13-9-09$ & $\begin{array}{l}\text { Coal processing waste banks. (B) Contamination of } \\
\text { waterways and intended future use. (E) Burned waste } \\
\text { utilization--removal of persons living in the } \\
\text { vicinity of the operation. (I)(1)(a) Inspection and } \\
\text { determination of threat to public health or } \\
\text { safety. (b) Inspection evaluation of potential } \\
\text { hazard. }\end{array}$ \\
\hline $1501: 13-9-11$ & $\begin{array}{l}\text { Protection of fish, wildijfe, and related } \\
\text { environmental values. } \\
\text { residential, public service, or industrial land use. }\end{array}$ \\
\hline $1501: 13-9-17$ & $\begin{array}{l}\text { Postmining use of land. Industrial, agricultural, } \\
\text { or retail application. }\end{array}$ \\
\hline $1501: 13-11-01$ & $\begin{array}{l}\text { other transportation facilities. (D) Prevent damage } \\
\text { to public or private property. }\end{array}$ \\
\hline $1501: 13-11-02$ & $\begin{array}{ll}\text { Support facilities and utility installations. } & \text { (A) } \\
\text { Prevent damage to private or public property. }\end{array}$ \\
\hline $1501: 13-12-03$ & $\begin{array}{l}\text { Subsistence control.iol (E) Prohidition of mining } \\
\text { beneath public buildings, churches, schools and } \\
\text { hospitals, or water impoundments. (J) Surface owner } \\
\text { notification. }\end{array}$ \\
\hline $1501: 13-13-04$ & $\begin{array}{l}\text { Mountaintop removal. }(A)(2) \text { Requirements for post } \\
\text { mountaintop removal--applications: } \\
\text { commercial, agricultural, residential, or public. }\end{array}$ \\
\hline $1501: 13-14-01$ & $\begin{array}{l}\text { Inspections. (G) Citizens request for inspection. } \\
\text { (H) Inforinal review. (I) Any person adversely } \\
\text { affected by coal exploration or coal mining and } \\
\text { reclamation. }\end{array}$ \\
\hline $1501: 13-14-02$ & $\begin{array}{l}\text { (A) (1)(a)(i) Imminent danger to the nealth or safety } \\
\text { of the public. (4) Reciamation should protect } \\
\text { public nealth and safety. }\end{array}$ \\
\hline $1501: 13-14-04$ & $\begin{array}{l}\text { Formal review by the chief. }(B)(1)(e) \text { Any person } \\
\text { with a valid legal interest. }(I)(2)(c) \text { Adverse } \\
\text { effect to the public nealth or safety. }\end{array}$ \\
\hline
\end{tabular}

(b)(2)(ii) Harm to the public or environment. (J)(1)(b) Public participation provided for in the rules. (6) Description of lands in the permit area. (M)(1) Minimize any adverse impacts to environment or public nealth and safety. (3)(a) Prevent significant, imminent environmental harm to the health and safety of the public.

Procedures, criteria, and schedule for release of performance bond. $(A)(6)(a)(i i)(a)$ Jurisdiction or expertise with respect to any environmental, social, or economic inpact involved in the operation. (E) Responsibility of compliance.

Use of explosives. (E)(6) Blasting within one-half mile of any public or private institution. (F)(7) Maximum ground vibration. waterways and intended future use (E) Burned waste utilization--removal of persons living in the vicinity of the operation. (I)(1)(a) Inspection and determination of threat to public health or safety. (b) Inspection evaluation of potential hazard. environmental values. (c) (9) Reclamation for residential, public service, or industrial land use. Postmining use of land. Industrial, agricultural, or retail application. to public or private property.

Support facilities and utility installations. (A) Sueve damage to private or public property. beneath public buildings, churches, schools and hospitals, or water impoundments. (J) Surface owner notification. mountaintop removal--applications: industrial, commercial, agricultural, residential, or public. (H) Infurinal review. (I) Any person adversely affected by coal exploration or coal mining and reclamation public health and safety. with a valid legal interest. (I)(2)(C) Adverse effect to the public health or safety. 


\section{UTAH}

Mined Land Reclamation Act

Title 40-8

Utah Code Annotated 1953

40-8-1. Citation

This act shall be known and may be cited as the "Utan Mined Land Reclamation Act."

40-8-2. Legislative Finding. (3) Reclamation should prevent conditions detrimental to the general safety and welfare to the citizens of the state. Provide for the subsequent use of the land. (7) Reclamation, consistent with local environinental conditions.

4n-8-5. Board and Divișion of $0 i 1$, Gas, and Mining Authority--Division of Health. (3) Nothing in this act is intended to abrogate or interfere with any powers or duties of the state Division of Health.

40-8-7. Board and Division--Authority--ilo retroactive effect for rules or regulations. (1)(e) Public liability and property damages of mining operators resulting from mining operations.

40-8-10. Notice and Procedure. Rules of civil procedure of redress of grievances.

40-8-12. Objectives. (1)(c) Reclamation should minimize or prevent future hazards to public safety and welfare.

40-8-13. Notice of Intention Required Prior to Mining Operations--Contents Confidential--Division Review and Decision. (4) Person or agency aggrieved may flle a written protest.

40-8-17. Responsibility of Operator to Comply with Applicable Rules, Regulations, and Ordinances--Inspections. (1) Compliance with all other applicable statutes, rules, regulations, and ordinances.

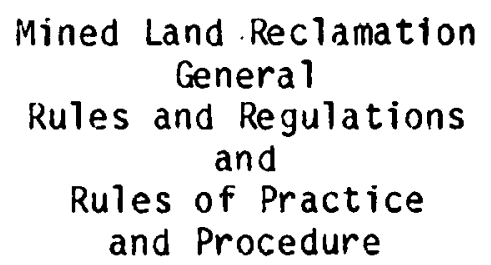

Rule $M-3$ Notice on Intention to Commence Mining Operations: (1)(d) Identify bodies of water, roads, buildings on the land to be affected. (2)(a) Prior and current uses of the land. (b) Possible uses of land following the termination of mining.

Rulc in-4 Notice to Public and Interested Parties: Notice to affected parties.

Rule $M-10$ Reclamation Standards: (2) Public Safety and Welfare--The operator shall minimize hazards to the public safety and welfare following mining. 


\section{HYOMIMG}

Industrial Development Information and Siting Act

W.S. 35-12-101. Citation. "Industrial Development Information and Siting Act."

35-12-102. (a)(vi) Definition. Impacted area. Social, economic, or environmental stress as determined by the council.

35-12-106. Permit from council required prior to commencing construction of facility; amendments; exceptions.

(c) Local ordinances and land use plans.

(e) Compliance with council, proof, alleviation of environmental, social, and economic impact.

35-12-107. Request for waiver of permit application; form; fee.

(b) Information to be contained in the application for a permit (ii, iii, iv, v, vi, viii, ix, $x, x i$ );

(c) Public notice;

(d) Public hearing;

(f) Meetings to determine the mitigation of adverse impacts;

(n) Presentation of evidence by applicant;

(i) Environinental, social, economic, (ii) notice of agreement with local governments affected by the proposed facility;

(j) Council findings, (i) impact on environmental, social, and economic, (ii) agreement with local governments, (iii) compliance with land use plans and local ordinances.

35-12-109. Application for permit; form; fee; financial accounting.

(a) Inforilation to be contained in the application. (iii, iv, v, vi, vii, viii, xii, xiii, xv, xvi, xvij, xvifi)

35-12-110. Service of notice of application; information and recommendations; application deficiencies, procedure; jurisdiction; hearing.

35-12-111. Parties to permit proceeding; waiver by failure to participate.

35-12-112. Record of hearing; procedure and rules of evidence. Any studies, investigations, reports, or other documentary evidence.

35-12-113. Decision of Council; findings necessary for permit conditions imposed; service of decision on parties. (a) $(i, i i, i j i)$

\section{Chapter I}

Industrial Development Information and Siting Rules and Regulations

Section 1. Authority. These rules and regulations are promulgated by the Wyoming Industrial siting Council pursuant to the autnority granted the council by the Wyoming Industrid? Development Information and Siting Act; W.S. 35-12-101 
through 35-12-121 (Laws 1975, Chapter 169; Laws 1977, chapter 66).

Section 2. Definitions. Definitions contained in section 1, W.S. 35-12-102, Industrial Development Information and siting Act shall be applicable, where appropriate. The following terms used in these regulations shall have the following meanings, unless the context otherwise requires:

(o) "Areas of site influence"

(p) "Area or local government primarily affected by the proposed facility $(i, i j)$.

(t) "Studies" include social, economic, or environmental.

Section 5. Application Information to be Submitted.

(c) Site location and areas of site influence.

(f) Inventory of materials flowing out of the facility (iv):

(n) Estimated number and job classification.

(k) Copies of studies.

(m) Evaluation of environmental, social, and economic impacts of the facility (ii, iii, iv, $v, v i$, vii, viii, ix, xiv, xvi, xviji).

(n) Transmission lines and other information. (i i)(A) Estimated location of construction force during construction period.

Section 6. Initial Determination.

(b) Threat of serious injury. (i) Environment (A)(B)(I)( $i$ i) Social conditions $(A-K)(i i i)$ Economic conditions $(A-I)(C)$ Substantially impair the health, safety, or welfare of the inhabitants (i) Definitions (11).

Section 8. Council Determination After Additional Study.

(a) Environmental impact (i, ii, iij, iv, v, vi, xi, $x i i)$.

(b) Design and location in meeting requirements $(1,111$, iv).

(c) Compatibility of facility with public nealth and safety.

(d) Land use plans.

(e) Compliance with applicable law.

(g) Facility represents an acceptable impact upon the environmental, social, and economic well-being of those within the area of site influence.

Section 8.1. Impact Assistance Funds.

(n) Cumulative effect of facility.

(a) Ratio for distribution of impact assistance funds ( $i$, ii, iii).

Section 8.2. Inpact Assistance Funds for Adjoining Counties. 


\author{
Cnapter II \\ Rules of Practice and Procedure \\ Industrial siting Council
}

Guide to the Preparation of Permit Applications for

Industrial Facilities

2. Permit Application

( $\left.i i, i_{i} i, i v, v, v i, v i i, x i, x i i, x i v, x v, x v i\right)$

3. Relationship of Permit Application to other State and. Federal Laws and Regulations.

(b) content.

B. Standard Format and Content of Permit Applications

$$
\begin{gathered}
\text { Chapter } 1 \\
\text { Summary of Permit Application }
\end{gathered}
$$

1.2 Project Summary

1.2.1 Summary of Adverse Environmental Impacts

1.2.2 Summary of Adverse Community Impacts

1.3 Monitoring and Mitigation

1.3.1 Environrnental Monitoring and Mitigation

1.3.2 Socioeconomic Monitoring and Mitigation

\title{
Chapter 2 \\ The Facility and Areas of Site Influence
}

2.3 Nature of Uperation

2.3.1 Proposed Un-Line Life

2.5 Areas of Site Influence and Relationship to Other Activities

2.5.1 Areas of Site Influence-Environment

2.5.2 Areas and Local Governments Prinarily Affected by the Facility

2.5.3 Relationship to other Activities in Area of Site Influence

\section{Cnapter 3 \\ Affected Environment}

3.6 Recreational and Visual Resources

3.7 Cultural Resources

\section{Chapter 4}

Social Profile

4.1 Current Area Economy

4.2 Projected Future Economy

4.3 Area Population

4.3.1 Current Population

4.3.2 Future Population

4. 4 Capital Facilities

4.4.1 Administration

4.4.2 Sewage Treatment

4.4.3 Water Treatment and Dislributiun

4.4.4 Solid Waste Disposal 
4.4.5 Law Enforcement

4.4.6 Fire Protection

4.4.7 Health Care Facilities and Personnel

4.4.8 Recreational Facilities

4.4.9 Library Facilities

4.5 Housing

4.6 Transportation

4.7 Human Services

4.8 Educational Facilities

4.9 Government and Public Finance

$$
\begin{gathered}
\text { Chapter } 5 \\
\text { Environmental Impacts of Construction and Operation }
\end{gathered}
$$

5.3 Effects of Land Use

5.5 Effects on Recreational and Visual. Resources

5.6 Effects on Cultural Resources

5.7 Cumulative Regional Impacts

5.8 Impact Controls and Mitigating Measures

\section{Chapter 6}

Socioeconomic Impacts of Construction and Uperation

6. 1 Construction Schedule and Estimated Construction Costs

6.2 Economic Effects of the Project

6.3 Population

6.4 Capital Facilities

6.4.1 Administration

6.4.2 Sewage Treatment

6.4.3 Water Treatment and Distribution

6.4.4 Solid Waste Disposal

6.4.5 Law Enforcement

6.4.6 Fire Protection

6.4.7 Health Care Facilities and Personnel

6.4.8 Recreational Facilities

6.4.9 Library Facilities

6.5 Housing

6.6 Transportation

6.7 Human Services

6.8 Educational Facilities

6.9 Government and Public Finance

6.10 Impact Controls and Mitigating Measures

Chapter 7

Public Healtn and Safety

Chapter 8

8.1 Monitoring of Environmental Effects

8.2 Monitoring of Socioeconomic Conditions

8.3 Reporting Schedules 
APPENDIX B

AN UPDATE OF PERMIT INFORMATION SYSTEM FOR SHALE OIL 


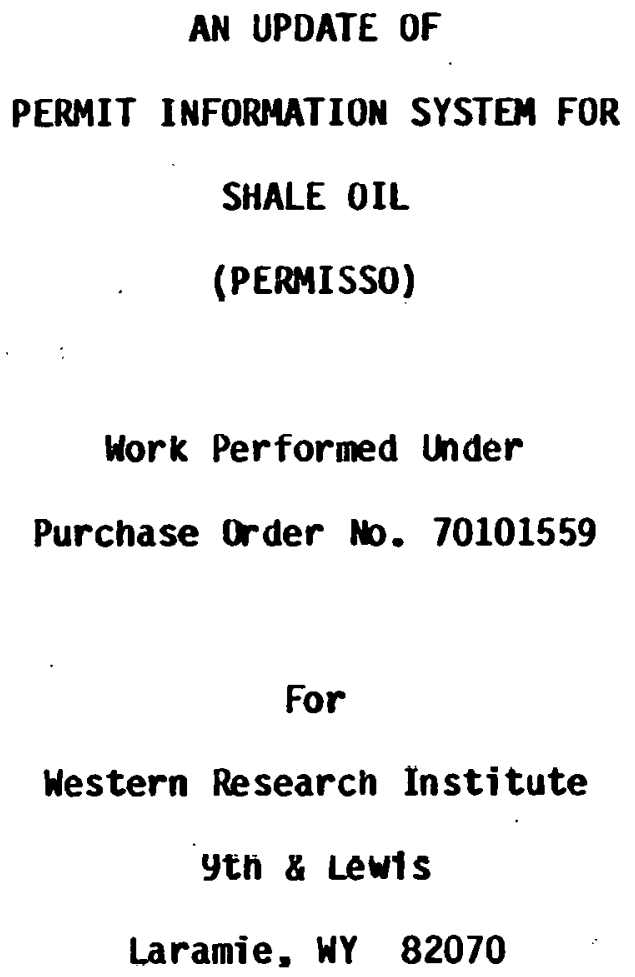

By

Larry W. Harrington

Attorney at Lav

P. 0. Box 214

Casper, HY 82602 


\section{DISCUSSION}

The permitting of an oil shale facility will be a complex task requiring extensive organization in order to accomplish the task in a timely manner. In 1979, the U.S. Department of Energy contracted with Science Applications, Inc. under Contract 31-109-38-3764; WU 79-007 to prepare a two-volume report entitled Development and Application of a Permit Information System for Shale 0il.

The report is being updated with the attached change sheets. In addition to updating the report for Colorado, Wyoming, and Utah, an effort has been made to identify permits that would be appiicable to the states of Kentucky, Indiana, and onio. No effort has Deen made to look at the county level.

Since the writing of PERMISSO in 1979, state laws have changed and regulations have changed. A four-volume set of C.F.R.'s that covered the E.P.A. in 1979 nas expanded to 10 volumes. The Resource Conservation and Recovery Act (RCRA) has generated more paper than all the rest of the environmental legislation combined.

The emphasis of this update has been toward environmental legislation. Caution must be exercised by the user of PERMISSO and the use of this update. The information provided points the user in the general direction that needs to be followed. HOWEVER, THIS REPURT IS NOT A SUBSTITUTE FUR DETAIL RESEARCH BY ATTORNEYS, ENGINEERS AND SCIENTISTS to identify the proper permits for a specific project. References to regulations are changing rapidiy. While substance is slow in change, fees, regulation numbers, and other details are changing.

\section{TIME ESTIMATES}

The time required for approval of a permit is very unpredictable. Where times have been set out, they are based only upon statutory mandates. The time estimates do not consider the time required to design equipment and collect data from base line studies. This process can take several years. For example, regulations require at least one year of baseline date prior to applying for a P.S.D. permit. Design of equipment will take some time before an application can be prepared. The regulations generally allow the regulation agency up to 180 days to disapprove or approve an application. If the application is not approved, the engineers will have to go back to the drawing board.

The time estimates do not include the time required to negotiate with the agencies. Questions such as what is the best available control technology for emission controls, and how should spent shale piles be stabilized, may cause several years of delay in obtaining permit approval. 
The numbering system used on the permits are as follows:

$\begin{array}{ll}\text { Federal } & 01000-01999 \\ \text { Colorado } & 02000-02999 \\ \text { Utan } & 03000-03999 \\ \text { Wyoming } & 04000-04999 \\ \text { Counties } & 05000-19999 \\ \text { Onio } & 20000-20999 \\ \text { Indiana } & 30000-30999 \\ \text { Kentucky } & 40000-40999\end{array}$

Permits not included in the update are water rights, rights-ofway, easements, and sight specific types such as requirements for Indian lands, BLM lands, and non-attainment areas. The emphasis on the Kentucky, Onio and Indian Permits has been toward the environmental approval.

Right-of-ways and easements will be necessary depending upon the ownership of property being crossed. Minimal attention has been given to airport licenses, labor laws, and approvals for handling explosives in order to give adequate coverage to major permitting areas in the limited time provided. The user should refer to colorado, Wyoming, and Utah rules to help identify less obvious permits and approvals. Tables 1 through 7 attached nereto will help identify these areas. 


\section{POTENTIAL}

FEDERAL PERMITS AND APPROVALS

Table 1

E.P.A.

Department of Agriculture

Department of Interior

Mine Safety and Health Administration

U.S. Treasury Department

Bureau of Alcohol, Tobacco and Firearms

Federal Aviation Administration

Interstate Commerce Commission

U.S. Department of Transportation

Department of Energy

Federal Communications Commission

POTENTIAL

PERMITS AND APPROVALS

FOR COLORADO

Table 2

Colorado Department of Health

Colorado Wildi ife Commission

Colorado State Historical Society

Mine Land Recreational Board

Buard of Land Commisstons

Department of Labor

0 il and Gas Conservation Commission

Bureau of Mines

Inspector of 0 ils

County Commissioner

Department of Institution

State Engineer

Groundwater Comrnission

Board of Examiners of Water Well and Pump Installation Contractors

Hignway Departinent

Public Utility Commission

Department of Revenue

Regional Planning

State Electrical Board 
POTENTIAL

PERMITS AND APPROVALS

FOR UTAH

Tab Te 3

$\begin{array}{lr}\text { Division of Health } & 8 \\ \text { Division of Wildife } & 4 \\ \text { Division of State History } & 4 \\ \text { Division of Parks and Recreation } & 2 \\ \text { Oil, Gas, and Mining } & 1 \\ \text { State Land Board } & 8 \\ \text { Industrial Commission } & 1 \\ \text { Public Service Commission } & 5 \\ \text { State Forestry } & 1 \\ \text { Environmental Coordinating Committee } & 1 \\ \text { Parks and Recreation } & 2 \\ \text { Division of State Lands } & 1 \\ \text { State Engineer } & 9 \\ \text { Natural Resources } & 1 \\ \text { State Tax Commission } & 2 \\ \text { Road Commission } & 1 \\ \text { Highway Patrol } & 2 \\ \text { Division of Aeronautics } & \end{array}$

POTENT IAL

PERMITS AND APPROVALS

FUR WYOMING

Table 4

Department of Energy Quality

Game and Fish

Wyoming Recreational Commission

Board of Land Commission

Inspector of Mines

0il and Gas Commission

Industrial Siding Council

Commission of Public Lands

State Engineer

Board of Control

Public Service Commission

Department of Fire Prevention

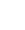




\section{POTENTIAL}

PERMITS AND APPROVALS

FUR OHIO

Table 5

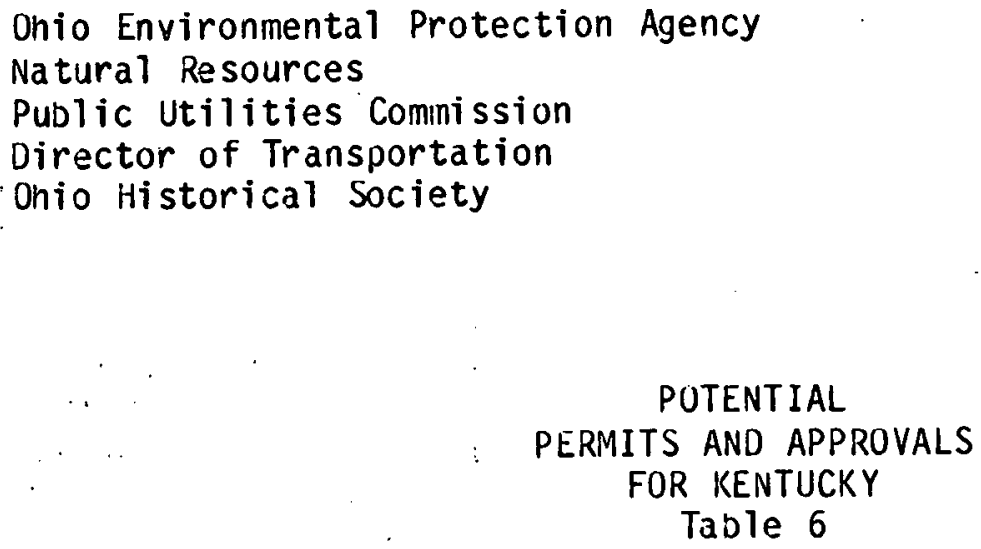

POTENTIAL

PERMITS AND APPROVALS

FOR KENTUCKY

Table 6

Natural Resources and Environmental Protection Cajinet 14

Department of Revenue

University of Kentucky

Energy Cabinet

Department of Transportation

Bureau of Venicle Regulation

Railroad Commission

Utility Regulatory Commission

PUTENTIAL

PERMITS AND APPROVALS

FOR INDIANA

Table 7

Department of Environmental Management

Departinent of Natural Re sources

Public Service Cominission

State Fire Marshal 
A. NAME OF PERMIT: Permit For Significant Deterioration of Air Quality

B. APPLICABILITY/DESCRIPTION: Applies to major stationary sources and major modifications.

C. AGENCY: E.P.A.

D. AUTHORITY: Clean Air Act. 42 U.S.C. 160

E. APPLICABLE REGULATIONS/STANDARDS: 41 C.F.R. 51.24

G. APPLICATION AND PREREQIIISITE RFQ̨IITRFMENTS: Permit roquiras control technology review, source impact analysis, air quality models, preapplication analysis, post-construction monitoring, operation of monitoring stations, submittal of data, additional impact analysis.

H. PROCESSING REQUIREMENTS :

3. Hearing Requirements/Notice: Review and public nearings required as in new source and modification permits for new sources. 
A. NAME OF PERMIT: New Source and Modification Permit for New Sources

B. APPLICABILITY/DESCRIPTIUN: Applies iff emissions exceed 100 tons per year of any pollutant subject to E.P.A. regulation

C. AGENCY: E.P.A.

D. AUTHURITY: Clean Air ACt 42 U.S.C.

E. APPLICABLE REGULATIONS/STANDARDS: 40 C.F.R. 51.18

G. APPLICATION AND PREREQUISITE REQUIREMENTS: These permits are required in every state. Authority to consider is either retained by: the E.P.A. or delegated to the respective states.

Applicants require information pertaining to amounts of emissions to be emitted, location, design, construction, and operation of such facility.

H. PRUCESSING REQUIREMENTS:

3. Hearing Requirements/Notice: A 30 day period for submittal of public comment required with public notice. Copy of notice to be submitted to E.P.A. 
A. NAME UF PERMIT: Underground Injection Control Permit

B. APPLICABILITY/DESCRIPTION: Applies to any owner or operator who constructs, operates, maintains, converts, plugs, abandons, or conducts any injection activity in a manner that allows movement of fluid containing any contaminant into underground sources of drinking water, if the presence of that contaminant may cause a violation of any drinking water regulation under 40 C.F.R. 142.

C. AGENCY: E.P.A. or State.

D. AUTHORITY: Safe Drinking Water Act. \$1421.

E. APPLICABLE REGULATIONS/STANDARDS: 40 C.F.R. 144.25

G. APPLICATIUN ANU PREKEQUISITE REQUIREMENTS: Application requires information concerning nature and type of injection, location and depth of wells, groundwater monitoring, analysis of injected fluids, description of geologic data.

H. PRUCESSING REQUIREMENTS:

4. Fee Schedule/Bond: Owner or operator must establish financial assurance for plugging and abandonment.

I. NATURE OF APPRUVAL:

2. Duration of Perinit: 10 year duration

3. Conditions: Proper operation and maintenance of facilities and systems of treatment and control, compliance with requests, allowance of entry and inspection, monitoring; record keeping, periodic reporting, reporting of noncompliance, meet criteria of 40 C.F.R. 146. 
A. NAME UF PERMIT: New Source Permit (Fugitive Dust)

B. APPLICABILITY/OESCRIPTION: $0.0 \cdot 0.0 \cdot 0 \cdot 0.10 .0$

C. AGENCY: Air Pollution Control Division, Colorado Department of Health

D. AUTHORITY: C.R.S. 1973, $\$ 25-7-101$ et seq. New open mining activities and other dust-generating activities must be granted a permit prior to operation.

E. APPLICABLE REGULATIONS/STANDARDS: Regulation 1, Sec. III.D,1

F. PRECEDENT PERMITS: Air contaminant emission notice

G. APPLICATION AND PREREQUISITE REQUIREMENTS: The Applicant must submit a plan including: (1) a description of the nature and scope of the existing or new source of fugitive dust; (2) preventative measures; (3) a time schedule for abatement and prevention; and (4) a description of monitoring methods.

H. PROCESSING REQUIREMENTS:

2. Staff Review Time: 95 days maximum

I. NATURE UF APPROVAL:

2. Duration of Permit: Any period of time as deemed appropriate by the Uivision.

3. Conditions: Any conditions deemed necessary to attain and maintain compliance with the provisions of $\$$ III.D. 
A. NAME OF PERMIT: Permit for Significant Deterioration

C. AGENCY: Colorado Department of Health

D. AUTHORITY: CRS 1986, 25-7-201. 
A. NAME OF PERMIT: Permit for New Stationary Source

C. AGENCY: Colorado Department of Health

D. AUTHORITY: CRS 25-7-114. No person shall construct or substantially alter any building, facility, structure, or installation, except single family residential dwellings, or install any machine, equipment, or other device, ... which will constitute a new stationary source without first obtaining or naving a valid permit.

E. APPLICABLE REgULATIUNS/STANDARDS: Regulation 3, Part IV.

'H.' PRUCESSING REQUIREMENTS:

2. Staff Review Time: If subject to PSO the public notice 30 days. Public hearing 60 days. Preliminary analysis 30 days. 
$\underline{02005.1}$

A. NAME OF PERMIT: Air Pollutant Emission Notice

C. AGENCY: Colorado Department of Health

D. AUTHORITY: CRS 25-7-114. No person shall permit emission of air pollution from, or construction or alteration of any facility, process, or activity except residential structures from which air pollutants are, or are to be, emitted unless and until an air pollutant emission notice has been filed with division in respect to such emission.

E. APPLICABLE REgULATIONS/STANDARDS: Regulation 3, Part II A.

G. APPLICATION AND PREREQUISITE REQUIREMENTS: Notices shall specify location and nature of facility, process or activity, and an estimate of quantity and composition of expected emission. 
A. NAME OF PERMIT: Notice of Commencement of Project

C. AGENCY: Colorado Department of Health

D. AUTHORITY: CRS 25-7-114(j). No person shall commence the operation of any project or the conduct of any activity for which a permit has been issued without giving at least 20 calendar days notice to the division. 
A. NAME OF PERMIT: Direct Air Contamination Source Emission Permit

B. APPLICABILITY/DESCRIPTION: $0.0 .0 \cdot 0.0 \cdot 0.10 .0$

C. AGENCY: Air Pollution Control Commission, Department of Health, State of Colorado

D. AUTHORITY: C.R.S. 1973, $\$ 25-7-114$

E. APPLICABLE REGULATIONS/STANDARDS: 5 C.C.R. 1001-2, Regulation No. 3

\section{F. PRECEDENT PERMITS: Planning meeting}

G. APPLICATION AND PREREQUISITE REQUIREMENTS: The application shall include equipment information, plans, descriptions, duplicate specifications and drawings sufficient in scope to allow an engineering evaluation to be made to determine whether appropriate air pollution control regulations and ordinances and ambient air quality standards will be met. If the Division determines it necessary, the application shall include acceptable ambient air monitoring and meterological data, modeling results and other evaluative techniques, procedures, and information.

H. PROCESSING REQUIREMENTS:

1. Number of Forms: Triplicate, with duplicate copies of all plans, specifications, and drawings.

2. Staff Review Time: Witnin 20 days of filing of application the Division shall prepare and make public its preliminary analysis. If public comment is warranted, the Division shall, within 15 days of preparation of preliminary analysis, publish public notice of application and file a copy of preliminary analysis with the appropriate county clerk. Public comment will be received and considered for 30 days after such publication. Within 30 days following the period for public comment or within 15 days after preparation of the preliminary analysis where no public comment is warranted, the Division shall grant or deny the permit. (Total: $35-60$ days after filing of application.) After 90 days have elapsed with no APCD action, the permit is deemed to have been granted.

3. Hearing Requirements/Notice: Applications subject to public comment shall be limited to those stationary direct sources that show annual emissions which exceed 25 tons.

4. Fee Schedule/Bond: $\$ 40.00$ filing a fee plus fee based on nourly rate for Division time spent, not to exceed $\$ 15,000.00$. 
I. NATURE OF APPROVAL:

1. Form of Approval: An emission permit will be issued, subject to a final approval to be given following inspection by the Division within 30 days after commencement of operation:

3. Conditions: The Division may impose continuing conditions on any permit necessary to meet continuous compliance with Section II.H.1. These may include installation, maintenance, and operation of equipment to monitor and record air quality, meterological, and emission data.

4. Reviews/Monitoring: The project will be inspected as notice in I.1. above and performance tests may be performed prior to granting final approval of emission permit. 
A. NAME OF PERMIT: Permit to Discharge Wastes

B. APPLICABILITY/DESCRIPTION: $0.0 .0 \cdot 0.0 \cdot 0.20 .0$

C. AGENCY: Board of Health, Committee on Water Pollution

D. AUTHORITY: U.C.A. 1953, $\$ 26-11-8$ (2)(b). It is unlawful for any person without first securing a permit from the executive secretary to construct, insta 11, modify, or operate any treatment works or part thereof or any extension or addition thereto, or construct, install, or operate and establish an extension or modification of or addition to i.t, the operation of which would result in a discharge.

E. APPLICABLE REgULATIONS/STANDARDS: Utah Code of Waste Disposal Regulations, Parts I through $V$. 
A. NAME OF PERMIT: Permit to Construct a Subsurface Disposal System

B. APPLICABILITY/OESCRIPTION: $0.0 .0 \cdot 0 \cdot 0.0 .10 .0$

C. AGENCY: Colorado Water Quality Control Commission, Division of Administration of the State Health Department

D. AUTHURITY: C.R.S. 1973, $\$ 25-8-501$ et seq. It is unlawful for any person to discharge, deposit, generate, or dispose of any radioactive, toxic, or other hazardous waste underground in liquid, solid, or explosive form, unless the Commission determines that there will be no pollution resulting therefrom or that the pollution, if any, will be limited to waters in a specified limited area from which there is no risk of significant migration and that the proposed activity is justified by public needs. The commission is interpreting "nazardous waste" to include any possible pollutant.

E. APPLICABLE REGULATIONS/STANDARDS: 5 C.C.R. 1002-4 controls the construction and/or operation of a subsurface disposal system.

G. APPLICATIUN AND PREREQUISITE REQUIREMENTS: The application shall contain such information as is 1 isted in 5 C.C. R. 1002-4. The Commission will accept for preliminary review applications setting forth in general terms the information. specified in $\$$ 7.2.4 in order to determine the general feasibility of the proposed system.

H. PROCESSING REQUIREMENTS:

3. Hearing Requirements/Notice: There shall be a public hearing upon at least 20 days notice. The applicant shall cause notice of every public hearing to be given by personal service to each surface and mineral owner of record within a 2 mile radius of the subject system, or it may give notice in a newspaper of the City and County of Denver and of the county in which the land affected by the system is located. In addition to notice of the hearing, notice of the application must also be given to the same persons.

I. NATURE UF APPROVAL:

3. Conditions: $\$ 7.2 .3(5)$ sets forth in detail the conditions of the permit.

J. ASSUCIATED AND/OR FOLLOW-UN PERMITS: Permit to operate subsurface disposal system. 
A. NAME OF PERMIT: Site Approval of Sewage Collection

B. APPLICABILITY/DESCRIPTION: $0.0 .0 \cdot 0.0 \cdot 0.10 .0$

C. AGENCY: Colorado Water Quality Control Commission, Division of Administration, Department of Health

D. AUTHORITY: C.R.S. $1973 \S 25-8-702$. No person shall cominence the construction or expansion of any domestic wastewater treatment work facilities intended to service more than 20 persons with a design capacity to receive more than 2,000 gallons per day unless the site location and construction has been approved and the design therefore reviewed by the commission.

E. APPLICABLE REgULATIUNS/STANDARDS: 5 C.C.R. 1002-12.

F. PRECEDENT PERMITS: NPDES Permit (see 02021)

G. APPLICATIUN AND PREREQUISITE REQUIREMENTS: Application can be obtained from the Water Quality Control Division, 4210 East 11 th Avenue, Denver, Colorado 80220, or from the District Engineer. If the proposed facility will be on or adjacent to any land owned or managed by a state or federal agency, a copy of the application shall be sent to such agency.

It shall de the responsibility of the applicant to submit the application form to the connecting entity, the treating entity, and to the applicable governmental authority (either the City, County or Mayor or County Commissioners as listed in $\$$ 2.2.4 (3) of 5 C.C.R. 1002-12)

H. PROCESSING REQUIREMENTS:

2. Staff Review Time: The Commission consideration of the proposed facilities shall be held at the next Commission meeting following a period which is not less than 30 days but no more than 90 days from receipt date. The 30 day limitation may be waived under $\$ 2.2 .5(9)$.

3. Hearing Requirements/Notice: Prior to submitting the application to the District Engineer, all applicants shall send copies of the form showing the date of mailing to the local Health authority and the regional Council of Governments and others pursuant to $\$ 2.2 .5(6)$. Applicant must post a sign on the subject property pursuant to $\S 2.2 .5$ (10)

I. NATURE OF APPROVAL

2. Duration of Perinit: Une year. 
02041 is deleted

A. NAME OF PERMIT:

B. APPLICABILITY/UESCRIPTION:

C. AGENCY:

D. AUTHORITY: 25-10-104 and 105. 
A. NAME OF PERMIT: Underground Injection Control Perinit

B. APPLICABILITY/OESCRIPTION: Applies to owner or operator who constructs, operates, maintains, converts, plugs, abandons, or conducts any injection activity in a manner that allows movement of fluid containing any contaminant into underground sources of drinking water, if the presence of that contaminant may cause a violation of any drinking water regulation under 40 C.F.R. 142.

E. APPLICABLE REGULATIONS/STANDARDS: 40 C.F.R. 147.301. Colorado Program effective 6-25-84.

G. APPLICATION AND PREREQUISITE REMIITREMENTS: Application requires information concerning nature and type of injection, location and depth of wells, groundwater monitoring, analysis of injected fluids, description of geologic date.

H. PROCESSING REQUIREMENTS:

4. Fee Schedule/Bond: Owner or operator must establish financial assurance for plugging and abandonment.

I. NATURE OF APPROVAL:

2. Duration of Perinit: 10 year duration

3. Conditions: Proper operation and maintenance of facilitios and systems of treatment and control, compliance with requests, allowance of entry and inspection, monitoring, record keeping, perindic reporting, reporting of noncompliance, ineet criteria of 40 C.F.R. 146. 
A. NAME UF PERMIT: Approval of Construction, Installation, or Establishment of Air Contaminant Source

B. APPLICABILITY/DESCRIPTION: $0.0 .0 \cdot 0.0 .0 .20 .0$

C. AGENCY: The Air Conservation Committee of the Division of Health of the State of Utan

D. AUTHORITY: U.C.A. 1953, $\$ 26-13-10$. Notice must be given to the executive secretary by any person planning to construct a new installation which will or might reasonably be expected to be a source or indirect source of air pollution or to make modifications to an existing installation which will or might reasonably be expected to change the amount or the character of air contaminants discharged, so that such installation may be expected to be a source or indirect source of air pollution, or by any person planning to install an air cleaning device or other equipment intended to control emission of air contaminants.

E. APPLICABLE REGULATIONS/STANDARDS: Utah Air Conservation Regulations, Section 3.1.

G. APPLICATIUN AND PREREQUISITE REQUIREMENTS: The executive secretary may require the submission of plans, specifications, and such other information as he deems necessary in order to determine whether the proposed construction, installation, or establishment will be in accord with applicable rules and regulations in force under this act.

H. PROCESSING REQUIREMENTS:

2. Staff Review Time: The executive secretary has 90 days after receipt of plans, specifications, and other information to determine whether the proposed construction, installation, or establishment or any part of it will or will not be in accord with the requirements of this act or that further time, not to exceed three extensions of 30 days each, is required by the committee to adequately review the plans, specifications, or other information.

3. Hearing Requirenents/Notice: Any person or persons aggrieved by the issuance of an order either granting or denying a request for the construction of a new installation sha11, upon request in accordance with the rules of the committee, be entitled to a hearing. Following the hearing, the permit may be affirmed, modified, or withdrawn.

1. NATURE UF APPROVAL:

1. Form of Approval: The executive secretary shall issue an order either granting or denying a request for the construction of a new installation. 
4. Reviews/Monitoring: Any duly authorized officer, employee, or representative of the committee may enter and inspect any property, premise, or place on or at which an air contaminant source is located or is being constructed, installed, or established at any reasonable time for the purpose of ascertaining the state of compliance with the act and rules and regulations in force under it.

J. ASSOCIATED AND/OR FOLLOW-ON PERMITS: PSD and EIS 
A. NAME OF PERMIT: Upen Burning Permit

B. APPLICABILITY/DESCRIPTION: 0.0 .0 .0 .0 .0 .20 .0

C. AGENCY: : Utah State Board of Health, Utan Air Conservation Committee

D. AUTHORITY: U.C.A. 1953, § 26-13-6. No open burning shall be done at sites used for disposal of community trash, garbage and other wastes except as authorized through a variance by the Air Conservation Committee.

E. APPLICABLE REGULATIONS/STANDARDS: Utan Air Conservation Regulations 2.4 
A. NAME UF PERMIT: Permit to Discharge Wastes

B. APPLICABILITY/DESCRIPTION: $0.0 .0 .0 \cdot 0.0 .20 .0$

C. AGENCY: Board of Health, Committee on Water Pollution

D. AUTHORITY: U.C.A. 1953, $\$ 26-11-8$ (2)(b). It is unlawful for any person without first securing a permit from the executive secretary to construct, instal1, modify, or operate any treatment works or part thereof or any extension or addition thereto, or construct, install, or operate and establish an extension or modification of or addition to $i t$, the operation of which would result in a discharge.

E. APPLICABLE REGULATIONS/STANDARDS: Utah Code of Waste Disposal Regulations, Parts I through V. 
A. NAME OF PERMIT: Notification of Spill or Discharge

B. APPLICABILITY/DESCRIPTION: $0.0 \cdot 0.0 \cdot 0.0 .20 .0$

C. AGENCY: Committee on Water Pollution of the Division of Health

D. AUTHORITY: U.C.A. 1953, $\$ 26-11-15$. Any spill of oil or other polluting substance into the waters of the state must be reported to the Committee. 
A. NAME OF PERMIT: Approval of Drinking Water System

B. APPLICABILITY/DESCRIPTION: $0.0 \cdot 0 \cdot 0 \cdot 0.0 .20 .0$

C. AGENCY: Bureau of Health

D. AUTHORITY: U.C.A. 1953, $\$ 26-12-15$. Approval is required if the system will. serve 15 or more service connectors or 25 or more people daily for at least 60 days per year. Approval is also required for a modification or addition to an existing system.

E. APPLICABLE REGULATIUNS/STANDARDS: Board of Health regulations for public water supplies.

H. PROCESSING REQUIREMENTS:

2. Staff Review Time: Approximately 1-2 months.

I. NATURE OF APPROVAL:

1. Form of Approval: Letter - needed prior to construction or a 1 teration

2. Duration of Permit: Indefinite

3. Conditions: Systein inspected prior to operation 
30046.1

A. NAME OF PERMIT: Permit to Operate Public Water Supply

C. AGENCY: Indiana Department of Environmental Management. Office of Water Management.

D. AUTHORITY: I.C. 13-7-10-1 (3) (A)

H. PROCESSING REQUIREMENTS:

5. Appeals: Petition within 15 days

I. NATURE OF APPROVAL:

2. Duration of Permit: Not to exceed 5 years 
A. NAME OF PERMIT: Underground Injection Control Permit

B. APPLICABILITY/DESCRIPTION: Applies to any owner or operator who constructs, operates, maintains, converts, plugs, abandons, or conducts any injection activity in a manner that allows movement of fluid containing any contaminant into underground sources of drinking water, if the presence of that contaminant may cause a violation of any drinking water regulation under 40 C.F.R. 142.

C. AGENCY: State of Utah Department of Health, Division of Environmental Health and Board of $0 i 1$ and Gas and iMining.

D. AUTHORITY: Utan Pollution Control Act. U.C.A. 26-11-2; 8-10. 40 l.r.K. $14 \% .2251$.

E. APPLICABLE REGULATIUNS/STANDARDS: Wastewater Disposal Regulations, Part VII U.I.C. Control Program; 011 Gas and Mining. Underground Injection Criteria and Standards.

G. APPIIICATION AND PREREQUISITE REQUIREMENTS: Application requires information concerning nature and type of injection, location and depth of wells, groundwater monitoring, analysis of injected fluids, description of geologic data.

H. PROCESSING REQUIREMENTS:

4. Tee Schedule/Bond: Owiter ur uperalur musl estavitsh financial assurance for plugging and abandonment.

I. NATURE UF APPROVAL:

2. Duration of Permit: 10 year duration

3. Conditions: Proper operation and maintenance of facilities and systems of treatment and control, compliance with requests, allowance of entry and inspection, monitoring, record keeping, periodic reporting, reporting of noncompliance, meet criteria of 40 C.F.R. 146. 
A. NAME OF PERMIT: Permit for Waste Disposal

B. APPLICABILITY/DESCRIPTION: $\quad 0.0 .0 \cdot 0.0 \cdot 0.20 .0$

C. AGENCY: State Board of Health, Utan Department of Social Services

D. AUTHORITY: U.C.A. 1953, $\S 26-14-5$. The Board of Health is empowered to establish minimum sanitary standards for the collection, treatment and disposal of sewage, industrial wastes and garbage and refuse, including control of the construction and operation of systems and approval of plans covering the construction and extension of inert construction debris used as fill material or mine tailings and overburden, provided such deposition does not cause a public nuisance or hazard or contribute to air or water pollution.

E. APPLICABLE REGULATIONS/STANDARDS: Code of solid Waste Disposal Regulations

G. APPLICATION AND PREREQUISITE REQUIREMENTS: Design plans and . related information shall be submitted to the Division of Health for review and approval prior to the construction of any solid waste disposal site. Such plans shale include those items set forth in the Code. ("Submission of Plans"-pp. 1 and 2)

I. NATURE OF APPROVAL:

3. Conditions: Each disposal site shall be operated as described in the Code under "Site Operation," pp. 3 and 4. 
A. NAME OF PERMIT: Prevention of Significant Deterioration (PSD) of Air Quality Permit Program

B. APPLICABILITY/OESCRIPTIUN: 0.0 .0 .0 .0 .0 .30 .0

C. AGENCY: Wyoming Department of Environmental Quality, Administrator of the Division of Air Quality

D. AUTHORITY: Clean Air Act, 42 U.S.C: $\$ 7465$ (\$165)

E. APPLICABLE REGULATIIUNS/STANDARDS: Wyoming Air Quality Standards and Regulations, Proposed Regulations to Prevent Significant Deterioration, $\S 24$. Impact analyses are identified in $\S 24$ and are required to be provided by anyone planning to construct any major enitting facility or modify an existing major emitting facility which may have the potential to cause the issuance of or an increase in the issuance of any air pollutant. These requirements apply only to those pollutants which cause the facility to be a "major emitting facility." Exceptions exist, including a major emitting facility or major modification with respect to emissions from which the owner or operator has shown to be fugitive dust.

H. PROCESSING REQUIREMENTS:

5. Appeals: In any case where the owner or operator of a proposed major emitting facility who has been denied a certification demonstrates to the satisfaction of the governor, after notice and public hearing, that a variance is called for, the governor may grant a variance from the maximum allowable increase for sulfur dioxide. 
04009

A. NAME OF PERMIT: Non-Attainment Construction Permit

B. APPLICABILITY/DESCRIPTION: $0.0 \cdot 0.0 \cdot 0.0 .30 .0$

C. AGENCY: Wyoming Department of Environmental Quality

D. AUTHORITY: Clean Air Act, 42 U.S.C. $\$ 7407,7053$ (\$107, 173)

E. APPLICABLE REGULATIUNS/STANDARDS: Wyoming Air Quality Regulations (1985) $\$ 25$. Sweetwater county contains a nonattainment area. Therefore the permit provisions of $\$ 173$ of the Clean Air Act (see 01009) apply. Wyoming must revise its State Implementation Plans prior to January 1, 1979, to reflect changes necessary to meet National Ambient Air Quality Standards in this area by December 31, 1982. 
A. NAME OF PERMIT: Air Quality Permit to Construct or Modify

B. APPLICABILITY/DESCRIPTION: $0.0 .0 \cdot 0 \cdot 0.0 .30 .0$

C. AGENCY: Environmental Quality Council, Department of Environmental Quality, Air Quality Division

D. AUTHORITY: Environmental Quality Act, W.S. 1977, $\$ 35-11-201$, 202. W.S. 1977, \$ 35-11-201 prohibits any person from discharging any air contaminant so as to cause pollution which violates rules, regulations and standards adopted by the Environmental Quality Council.

W. S. 1977, \$35-11-202 provides that the administrator shall recommend to the director and the Environmental Quality Council such standards and regulations as are necessary to prevent, abate, or control pollution.

E. APPLICABLE REgULATIONS/STANDARDS: Wyoming Air Quality Standards and Regulations, 1985, $\S 21$. These provide all of the specific emission limitations governing each pollutant. The regulations further require that a permit to construct or modify be obtained prior to commencing construction of any new facility. To obtain the permit to construct, the applicant must demonstrate that the facility will comply with all omission limitations, and its standards, the best available control technology, and prevent the significant deterioration of air quality. 
A. NAME OF PERMIT: Air Quality Permit to Operate

B. APPLICABILITY/DESCRIPTION: $0.0 \cdot 0.0 .0 .0 .30 .0$

C. AGENCY: Department of Environmental Quality, Air Quality Division

D. AUTHURITY: Environmental Quality Act, W.S. 1977, \$35-11-202. The statute authorizes the administrator to promulgate rules and regulations necessary to prevent, abate, or control pollution.

E. APPLICABLE REGULATIONS/STANDARDS: Wyoming Air Quality Standards and Regulations, $1985 \$ 21$ (a) (ii). These require that a permit to operate be obtained within 120 days from start up of the facility. The permit to operate will not be granted unless the facility is complying with the Wyoming Air Quality Standards and Regulations and was constructed or modified in accordance with requirements contained in the permit to construct or modify. 
A. NAME OF PERMIT: Permit to Discharge Waste Water

B. APPLICABILITY/DESCRIPTION: $\quad 0.0 .0 \cdot 0.0 \cdot 0.30 .0$

C. AGENCY: Department of Environmental Quality, Water Quality Division

D. AUTHORITY: Environmental Quality Act, W.S. 1977, $\$ 35-11-301$ (a) (i), 302 (a) (v). W.S. 1977, \$ 35-11-301 (a) (v) prohibits any person from discharging any pollution into waters of the state without a permit.

W.S. 1977, $\S 35-11-302$ requires that the Department of Environmental Quality promulgate rules and regulations for effiuent standards and limitations specifying maximum amounts of concentrations of pollutions that may be.discharged into waters of the state and standards for the issuance of discharge permits pursuant to $\$ 402$ (D) of the Federal Water Pollution Control Act.

E. APPLICABLE REGULATIONS/STANDARDS: Wyoming Water Quality Standards and Regulations, 1974, Chapter II, Wyoming Water Quality Standards and Regulations, 1978, Chapter I and Water Quality Rules and Regulations, Chapter VIII (1980). These require a permit for the discharge of any waste into waters of the State of Wyoming. The regulations further specify specific effluent limitations governing different pollutants, procedures for the issuance of permits and compliance schedules, and procedures for renewing permits. 
A. NAME . OF PERMIT: Subsurface Discharge Permit

B. APPLICABILITY/DESCRIPTION: $0.0 \cdot 0 \cdot 0 \cdot 0 \cdot 0.30 .0$

C. AGENCY: Department of Environmental Quality, Water Quality Division

D. AUTHORITY: Wyoming Environmental Quality Act, W.S. 1977 35-11$301,302$.

E. APPLICABLE REGULATIONS/STANDARDS: Wyoming Water Quality Rules and Regulations, Chapter IX. The regulations provide for the submittal of detailed information concerning any planned subsurface discharge facility; specific analytical techniques to be used on water quality sampling, specific monitoring records, and permit processing procedures. 
A. NAME OF PERMIT: Permit for Special Process Discharge for IN/SITU Mining (Proposed)

B. APPLICABILITY/DESCRIPTION: $1,3 \cdot 0 \cdot 0 \cdot 0 \cdot 0.0 .30 .0$

C. AGENCY: Department of Environmental Quality, Water Quality and Land Quality Divisions

D. AUTHORITY: Wyoming Environmental Quality Act, W.S. 1977, \$3511-426 et seq.

E. APPLICABLE REGULATIONS/STANDARDS: Land Quality Rules and Regulations, Chapter XXI. The regulations provide for the submission of application information on IN/SITU mining facilities, a description of the operation, a waste control program, and extensive hydrologic testing and monitoring. 
A. NAME OF PERMIT: Underground Injection Control Permit

B. APPLICABILITY/OESCRIPTION: Applies to any owner or operator who constructs, operates, maintains, converts, plugs, abandons, or conducts any injection activity in a manner that allows movement of fluid containing any contaminant into underground sources of drinking water, if the presence of that contaminant may cause a violation of any drinking water regulation under 40 C.F.R. 142.

C. AGENCY: Wyoming Department of Environmental Quality and Wyoming 0i1 and Gas Commission, as amended by Cause No. 1, Order No. 29, Docket No. $222081(10-31-81)$, as amended by correction order Cause No. 29, Docket No. 222-81 (11-10-81)

D. AUTHORITY: $35-11-103,301,401,405,406,408,415,426$ through 430 (1977 and Supp. 1983)

E. APPLICABLE REgULATIONS/STANDARDS: 40 C.F.R. 147.2550; Water Quality Rules and Regulations; Chapter III: Regulations for permit to construct, install, or modify public facilities capable or causing or contributing to pollution; Water Quality Rules and Regulations, Chapter VIII; Quality Standards for Groundwaters of Wyoming; Chapter IX: Wyoming Groundwater Pollution Control Perinit; Land Quality Rules and Regulations, Chapter XXI; In Situ Mining.

G. APPLICATIUN AND PREREQUISITE REQUIREMENTS: Application requires information concerning nature and type of injection, location and depth of wells, groundwater monitoring, analysis of injected fluids, description of geologic data.

H. PRUCESSING REQUIREMENTS:

4. Fee Schedule/Bond: Owner or operator must establish financial assurance for plugging and abandonment.

I. NATURE UF APPRUVAL:

2. Duration of Permit: 10 year duration

3. Conditions: Proper operation and maintenance of facilities and systems of treatment and control, compliance with requests, allowance of entry and inspection, monitoring, record keeping, periodic reporting, reporting of noncompliance, meet criteria of 40 C.F.R. 146. 
A. NAME OF PERMIT: License to Explore by Dozing

B. APPLICABILITY/DESCRIPTION: $0.0 .0 .0 \cdot 0.0 .30 .0$

C. AGENCY: Department of Environmental Quality, Land Quality Division

D. AUTHORITY: Environmental Quality Act, W.S. 1977, $\$ 35-11-413$, 414. W.S. $1977 \S 35-11-413$ provides that a special license to explore by dozing may be issued by the administrator of the land quality division for one year periods without a permit to mine.

W.S. $1977 \S 35-11-414$ provides that a license to cxplore oy dozing shall be issued requiring reclamation of the area affected by the exploration and for the posting of a bond to cover costs of reclamation.

E. APPLICABLE REGULATIONS/STANDARDS: Wyoming Land quality Rules and Regulations, 1986, Chapter $X$. These require that a license to explore by dozing be obtained prior to any exploration activity in which earth moving equipment is used, and provides that the contents of the application include maps and reclamation plans. It also provides the procedures for license issuance and renewal.

H. PROCESSING REQUIREMENTS:

4. Fee Schedule/Bond: $\$ 25.00$ fee; Dond to insure reclamation as established by the Administrator.

I. NATURE OF APPROVAL:

2. Duration of Permit: One year only for special license. A permit is required for longer periods.

3. Conditions: Land must ve reclaimed after completion of the exploration. Failure to comply with conditions may result in forfeiture of the bond. 


\section{2}

A. NAME OF PERMIT: Permit for Significant Deterioration

C. AGENCY: U.S. Environmental Protection Agency, Application to be sent to Onio Environmental Protection Agency

D. AUTHORITY: 42 U.S.C. $160 ; \cdot 0 . A \cdot C \cdot 3704.03$

E. APPLICABLE REGULATIONS/STANDARDS: 40 C.F.R. 52.1884. The State of Onfo's Implementation Plan has not been approved for P.S.D.

G. APPLICATION AND PREREQUISITE REQUIREMENTS: See discussion under Federal Requirements. 
A. NAME OF PERMIT: Permit for Construction or Modification of Air Contamination Source

C. AGENCY: Onio Environmental Protection Agency

D. AUTHORITY: O.A.C. 3704.03. Director shall issue permits to prohibit the location, installation, construction, or modification or any air contamination source or any machine, equipment, device, apparatus, or facility intended primarily to prevent or control the emission of air contaminants, unless an installation permit therefore has been obtained.

Application shall be accompanied by plans, specifications, construction schedules and such other pertinent information and data, including data on ambient air quality impact, as the director may require.

E. APPLICABLE REGULATIONS/STANDARDS: OAC 3745-15;3745-31-02

H. PROCESSING REQUIREMENTS:

2. Staff Review Time: 180 days to issue, propose to issue or deny 3745-47.

3. Hearing Requirements/Notice: A 30 day period for submittal of pubiic comment.

5. Appeals: Onio Administrative Code sets out procedures 374547.

I. NATURE OF APPROVAL:

1. Form of Approval: Permit.

2. Duration of Permit: Issued for period specified by director.

3. Conditions: Agency may require submission of emission information, measurements, etc.

4. Reviews/Monitoring: May require person responsible for any air contaminant source to install, employ, maintain and operate such emissions, ambient air quality, meteorological, or other monitoring devices or methods. UAC 3745-15-03. 3745-15-04. 
$\underline{20011}$

A. NAME OF PERMIT: Permit to Operate Air Contamination Source

C. AGENCY: Onio Environmental Protection Agency

D. AUTHURITY: O.A.C. $3704-03$

E. APPLICABLE REGULATIONS/STANDAROS: 37435-35-02

F: PRECEDENT PERMITS: Permit to Construct

H. PROCESSING REQUIREMENTS:

2. Staff Review Time: File 90 days prior to start-up. 
A. NAME OF PERMIT: Upen Burning Permit

C. AGENCY: Onio Environmental Protection Agency

E. APPLICABLE REGULATIONS/STANDARDS: 3745-19-03

I. NATURE OF APPROVAL:

1. Form of Approval: Open burning is prohibited except for 1 imited exceptions. 
A. NAME OF PERMIT: Discharge Permit

C. AGENCY: Ohio Environmental Protection Agency

D. AUTHORITY: O.A.C. 6111.04

E. APPLICABLE REGULATIONS/STANDARDS: 3745-33-02

G. APPLICATION AND..PREREQUISITE REQUIREMENTS: No person shall cause pollution or place.or cause to be placed any sewage, industrial waste, or other wastes in a location where they cause pollution of any waters or the state in which any such act is declared to be a public nuisance, except in such cases where the director of environmental protection has issued a valid unexpired permit:

H. PROCESSING REQUIREMENTS:

2. Staff Review Time: 180 days

I. NATURE OF APPROVAL:

2. Duration of Permit: 5 years

3. Conditions: Annual reporting, continued compliance.

5. Renewal Procedures: Must apply 180 days prior to expiration. 
A. NAME UF PERMIT: Construction Permit for Storing, Conserving or Retaining Water

C. AGENCY: Unio Department of Natural Resources, Division of Water

D. AUTHORITY: 0. A.C 1521.06

G. APPLICATION AND PREREQUISITE REQUIREMENTS: Application shall include two copies of the plans and specifications, including a detailed cost estimate for proposed construction. prepared by a registered professional engineer.

H." PROCESSING REQUIREMENTS:

2. Staff Review Time: 30 days to approve or deny

1. NATURE UF APPROVAL:

1. Form of Approval: Permit to construct

J. ASSUCIATED AND/OR FOLLOW-ON PERMITS: Bond and securities may be released upon elapse of one year following approval of construction permit. 
A. NAME OF PERMIT: Permit for Construction of Public Water System

C. ' AGENCY: Onio Environmental Protection Agency

D. AUTHORITY: O.A.C. 6109.07

G. APPLICATION AND PREREQUISITE REQUIREMENTS: No person shall begin construction or installation of a public water system or make a substantial change in a public water system until plans have been approved by the director of environmental protection.

A public water system is one that provides piped water for human consumption, if such system has at least. 15 service connections or regularly serves at least 25 individuals. 
A. NAME UF PERMIT: Underground Injection Control Permit

B. APPLICABILITY/DESCRIPTION: Applies to any owner or operator who constructs, operates, maintains, converts, plugs, abandons, or conducts any injection activity in a manner that allows movement of fluid containing any contaminant into underground sources of drinking water, if the presence of that contaminant may cause a violation of any drinking water regulation under 40 C.F.R. 142.

C. AGENCY: Unio Department of Naturat Resources

D. AUTHURITY: Onio Revised Code Annotated 1509.01, 1509.03, 1509.221.

E. APPLICABLE RFGIILATIONS/STANDARDS: 40 C.F.R. 14\%.1800; 48 FR 38238; Rules of the Division of 0il \& Gas, 0.A.C. 1501: 9-7-01 through 7-14 (1984); ORCA $\S 6111.04,6111.043,6111.044$. Rules of the Onio E.P.A., OAC (Director Onio E.P.A. Order 6-18-84)

G. APPLICATIUN AND PREREQUISITE REQUIREMENTS: Application requires information concerning nature and type of injection, location and depth of wells, groundwater monitoring, analysis of injected fluids, description of geologic data.

H. PROCESSING REQUIREMENTS:

4. Fee Schedule/Bond: Owner or operator must establish financial assurance for plugging and abandonment.

I. NATURE UF APPRUVAL:

2. Duration of Permit: 10 year duration

3. Conditions: Proper nperation and ilidintenance of facilities and systems of treatment and control, compliance with requests, allowance of entry and inspection, monitoring, record keeping, periodic reporting, reporting of noncompliance, meet criteria of $40 \mathrm{C} . \mathrm{F} . \mathrm{R}$. 146. 


\section{1}

A. NAME OF PERMIT: Permit for Solid and Waste Facilities

C.. AGENCY: Onio Environmental Protection Agency

D. AUTHURITY: O.A.C. 3734, Resource Conservation and Recovery Act 42 U.S.C. 6921

E. APPLICABLE REGULATIONS/STANDARDS: 3745-31-02; 3745-45-01

G. APPLICATION AND PREREQUISITE REQUIREMENTS: APplication requires detail plans, specifications, and information regarding the facility and method of operation.

H. PROCESSING REQUIREMENTS:

2. Staff Review Time: If nazardous wastes are involved, the application must be approved by the hazardous waste facility approval board. Must have hearing with 60 to 90 days of receipt by board and in adjudication hearing within 4. Fee Schedule/Bond: Set by 3745-01

I. NATURE OF APPROVAL:

3. Conditions: An annual survey of solid waste facilities is required by 0. A.C. 3734.08 . 


\section{1}

A. NAME OF PERMIT: Hazardous Material Transportation

C. AGENCY: Unio Environmental Protection Agency

D. AUTHORITY: O.A.C: $3734.12 ; 49$ U.S.C. 1801 Hazardous Materials Transportation Act

G. APPLICATIUN AND PREREQUISITE REQUIREMENTS: Regulation requires records of all hazardous waste that is treated, stored, disposed of and the manner in which waste was treated, stored, and disposed of. 3745-27-06

H. PROCESSING REQUIREMENTS:

1. Number of Forms: Registration Certificate required U.A.C. 3734.50

I. NATURE OF APPRUVAL:

1. Form of Approval: Records must be maintained, containers labeled. Appropriate containers must be used. Information must be provided concerning composition of nazardous wastes for transportation, treating and storing and a manifest system consistent with 42 U.S.C.A. 6901.

4. Reviews/Monitoring: Reports must be made to agency. 
A. NAME OF PERMIT: Permit for Injection of Liquid Wastes

C. AGENCY: Onio Environmental Protection Agency

D. AUTHORITY: O.A.C. 6111.043

E. APPLICABLE REGULATIUNS/STANDARDS: No person shall use a well for the injection of sewage, industrial waste, or other wastes, without having a liquid disposal permit. OAC 3745-34

G. APPLICATION ANO PREREQUISITE REQUIREMENTS: Application requires general information concerning the owner; geological formations to be tested or used, and proposed total depth, type of equipment plan for disposal of water and other waste substances resulting obtained, or produced in connection with drilling.

H. PROCESSING REQUIREMENTS:

4. Fee Schedule/Bond: $\$ 25.00$

I. NATURE UF APPROVAL:

2. Duration of Permit: If within 5000 feet of mine - chief of division of mines must service (0.A.C. 6111.044) 


\section{8}

A. NAME OF PERMIT: Endangered Species

C. AGENCY: Department of Natural Resources

D. AUTHORITY: O.A.C. 1518.05

I. NATURE UF APPROVAL:

1. Form of Approval: Violation of Rules Pronibited 
20080.1

A. NAME OF PERMIT: Permit for Use of Natural Area

C. AGENCY: Department of Natural Resources, Division of Natural Areas and Preserves

D. AUTHORITY: O.A.C. 1517.01 
A. NAME OF PERMIT:- Permit to Disturb Archaeological and Historical Sites

C. AGENCY: Onio Historical Society

D. AUTHORITY: UAC 149.51. No person shall engage in archaeologica? survey or salvage work on any land that is owned, controlled, or administered by the state or any political subdivision of the state, or at any archaeological preserve, ... or any state archaeological landmark, without first obtaining written permission.

G. APPLICATIUN AND PREREQUISITE REQUIREMENTS: Application must indicate the proposed location, the qualifications or personnel, methods of survey or salvage and other information required by rules. 
20185.1

A. NAME OF PERMIT: Recreational Trails

C.: AGENCY: Department of Natural Resources

D. AUTHURITY: O.A.C. 1518.05

I. NATURE UF APPROVAL:

1. Form of Approval: Violation of Rules Prohibited 
A. NAME OF PERMIT: Mine and Reclamation Plan

C. AGENCY: Department of Natural Resources, Division of Reclamation

D. AUTHORITY: 0.A.C. 1514.02. Section 1514.01 defines "surface mining" as all or any part of a process followed in the production of minerals from the earth or from the surface of the land by surface excavation methods...., and the incidental removal of coal. at a rate less than one-sixth the total weight of minerals and coal removal during the year.

The term does not include test or exploration boring; mining operations carried out beneath the surface by means of shafts, tunnels, or similar mine openings.

F. PRECEDENT PERMITS: Certificate of public liability insurance.

G. APPLICATION AND PREREQUISITE REQUIREMENTS: Application includes general data on the applicant and mine, accompanied by a list of minerals to be extracted, estimation of acres of land to be affected, a copy of deeds and leases; mine and reclamation plan, a certificate of public liability insurance.

H. PROCESSING REQUIREMENTS:

2. Staff Review Time: 90 days to approve or deny

4. Fee Schedule/Bond: $\$ 150+\$ 30 /$ acre not to exceed $\$ 1,000 / y r$.

I. NATURE OF APPRUVAL:

1. Form of Approval: Permit

2. Duration of Permit: Annual report and final report within 30 days of expiration of permit

3. Conditions: Compliance with approved permit and plans. 
A. NAME OF PERMIT: Well Drilling Logs

C. AGENCY: Department of Natural Resources, Division of Water

D. AUTHORITY: 0.A.C. 1521.05

I. NATURE OF APPROVAL:

1. Form of Approval: Furnish log to division within 30 days after completion of drilling, boring, digging, deepening, altering or changing well. 
A. NAME OF PERMIT: Pipeline Safety

C. AGENCY: Public Utilities Commission

D. AUTHORITY: OAC 4905.03(A) (7), OAC 4905.06. 'The Public Utilities Commission shall inspect for the purposes of public safety, all gas and natural gas pipeline owned, operated, or controlled by public utilities. 


\section{1}

A. NAME OF PERMIT: Private Motor Carrier Permit

B. APPLICABILITY/DESCRIPTION: Applies when engaged in business of private carriage of persons or property.

C. AGENCY: Public Utilities Commission

D. AUTHORITY: OAC 4923.01 et seq.

H. PROCESSING REQUIREMENTS:

3. Hearing Requirements/Notice: 3 week publication 


\section{$\underline{20605}$}

A. NAME OF PERMIT: Permit to use Road for Pipeline.

C. AGENCY: Director of Transportation

D. AUTHORITY: OAC 5515.01. The Director of Transportation may upon formal application being made, to him, grant a permit to occupy such portion of a road or highway on the state highway system as will not incommode the traveling public.

I. NATURE OF APPROVAL:

3. Conditions: 0ccupancy shall be a location as prescribed by the director; location shall be changed when necessary, need to be fully restared, maintenance required, permit may be revoked. 
A. NAME OF PERMIT: Permit for Significant Deterioration

C. AGENCY: Indiana Department of Environmental Management/Air Pollution Control Board

D. AUTHORITY: I.C. $13-7-10-1$

E. APPLICABLE REGULATIONS/STANDARDS: 325 I.A.C. $2-2$

G. APPLICATION AND PREREQUISITE REQUIREMENTS: New Major stationary PSD source shall apply best available control technology, air quality impact. Applies to stationary sources which are located in attainment area and which nave potential to emit 100 tons of regulated pollutants.

H. PROCESSING REQUIREMENTS:

2. Staff Review Time: 1 year (325 I.A.C. 2-1.1-3 (y) I1)

3. Hearing Requirements/Notice: Public notice with 30 day pubi ic comment

4. Fee Schedule/Bond: $\$ 500$ per source plus other miscellaneous charges

5. Appeals: Petition within 15 days

I. NATURE UF APPROVAL:

3. Conditions: May establish emissions limitation. 
A. NAME OF PERMIT: Air Emissions Permit for Construction.

C. AGENCY: Indiana Department of Environmental Management/Air Pollution Control Board

D. AUTHURITY: I.C. 13-7-10-1 (1) (B); I.C. 13-1-1-4; I.C. 13-7-5-1

E. APPLICABLE REGULATIONS/STANDARDS: 325, I.A.C 2-1.1-2, (Applies with less than 25 tons/year); 325 2-1.1-3'325 I.A.C. 2-1.1-4 and 325 I.A.C. 2-1.1-7. Applies to facilities with potential emission of 25 tons or more per year.

G. APPLICATION AND PREREQUISITE REQUIREMENTS: The permit application requires a description of the nature, location, design capacity, and operating schedule of the source, facility, or emission control equipment including the design specifications, a time schedule for construction, or modification of the source, facility or emission control equipment and information on the nature and amount of pollutants to be emitted. Construction period required as prerequisite to registration of source. Must show that source will meet requirements of Clear Air Act.

H. PROCESSING REQUIREMENTS:

2. Staff Review Time: 90 days to accept registration or request inore information; Construction permit - 30 days for preliminary review; then detall review. Permit shall be issued or dented within one year of receipt of all information for major stationary P.S.D. Source.

3. Hearing Requirements/Notice: Public hearing with 30 days notice.

4. Fee Schedule/Bond: A fee upon billing approximating cost of processing and review.

5. Appeals: controversy shall be resolved by the Board. Petition within 15 days.

I. NATURE OF APPROVAL:

3. Conditions: Board may require monitoring to show compliance with applicable air pollution control rules. 
A. NAME OF PERMIT: Air Emissions Operating Permit

C. AGENCY: Indiana Department of Environmental Management/Air Pollution Control Board

D. AUTHORITY: I.C. $13-7-10-1$

E. APPLICABLE REGULATIONS/STANDARDS: 325 I.A.C. 2-1.1-4

G. APPLICATION AND PREREQUISITE REQUIREMENTS: Must show that planned emissions do not exceed emissions designated for facility. Performance testing may be required.

H. PROCESSING REQUIREMENTS:

4. Fee Schedule/Bond: $\$ 85.00$

5. Appeals: Controversy shall be resolved by the Board. Petition within 15 days.

I. NATURE OF APPROVAL:

1. Form of Approval: Permit

2. Duration of Permit: 4 years

3. Conditions: May establish emissions limitation.

4. Reviews/Monitoring: May require performance testing.

5. Renewal Procedures: Must apply at least 90 days prior to expiration. 
A. NAME OF PERMIT: Permit to Discharge Contaminants Into State Waters

C. AGENCY: Indiana Department of Environmental Management. Office of Water Management.

D. AUTHURITY: I.C. $13-7-10-1$ (1) (A); I.C. 13-1-3-7; 13-1-4-1 et seq.

E: APPLICABLE REGULATIONS/STANDARDS: 330 I.A.C. 3.1-1-1 sets out requirements for issuance of permits for. construction of water pollution treatment/control facilities. Application requires general information about the applicant, topographic maps, a description of the nature of the business, a description of the drainage area, receiving water, treatinent, and discharge characteristics.

F. PRECEDENT PERMITS: Environmental Impact Statement may be required.

H. PROCESSING REQUIREMENTS:

2. Staff Review Time: 4 to 6 months or longer.

4. Fee Schedule/Bond: $\$ 150+\$ 50$ per additional source.

5. Appeals: Petition within 15 days.

1. NATURE UF APPROVAL:

2. Duration of Permit: Not to exceed 5 years.

3. Conditions: Permit requires compliance with conditions, duty to provide information, monitoring and records, reporting of planned changes, reporting of non-compliance. 
A. NAME OF PERMIT: Dredge, Change or Alter

C. AGENCY: Indiana Department of Environmental Management

D. AUTHORITY: I.C. 12-3-17-3. It shall be unlawful to interfere with, change or alter, or attempt to interfere with, change or alter any bank, dam, spillage, outlet or outlets of any fresh water lake or lakes or dredging, or to dig or dredge, or in any way lower or attempt to lower, any outlet or part of outlet to any such lake at any point at such outlet within 240 rods of any such lake. 
30030.1

A. NAME OF PERMIT: Permit to Construct Channel

C. AGENCY: 1.C. 13-2-18.5-4. Any person desiring to construct a channel shall first file a verified written application for a permit with the commission.

G. APPLICATION AND PREREQUISITE REQUIREMENTS: Applicants must De accompanied by material facts with plans and specifications for construction of the channel and facility or facilities and for which it will provide access.

H. PRUCESSING REQUIREMENTS:

4. Fee Schedule/Band: $\$ 100.00$ 
A. NAME OF PERMIT: Permit for Construction and Operation of Wastewater Treatment Plant

C. AGENCY: Indiana Department of Environmental Management - Stream Pollution Control Board

D. AUTHORITY: I.C. 13-1-3-7; 13-1-4-2; I.C. 13-7-7-5; 1.C. 13-1-3$10 ; 13-7-10-1$ (3) (B). The Board may require permits for the construction, installation or modification of facilities, equipment or devises.

To control or limit any discharge, emission or disposal of contaminants into the environment or into a publicly owned treatment works. (I.C. 13-1-3-10).

E. APPLICABLE REGULATIONS/STANDARDS: 330 I.A.C. $3.1-1-1 ; 330$ I.A.C. 3.1-2-1; 330 I.A.C. 3.1-4-1 (Applies to facilities not regulated by NPDES)

G. APPLICATION AND PREREQUISITE REQUIREMENTS: Application requires construction plans and specifications capable of being microfilmed, a project design summary.

H. PRUCESSING REQUIREMENTS:

2. Staff Review Time: Application must be submitted 60 days prior to proposed date.

5. Appea1s: Petition within 15 days.

I. NATURE UF APPROVAL:

2. Duration of Perinit: Not to exceed 5 years

J. ASSOCIATED AND/OR FOLLOW-ON PERMITS: Submit as-built plans 330 I.A.C. 3.1-3-1. Operation permits are required by 330 I.A.C. 3.1-4-1. 
30040.1

A. NAME OF PERMIT: Sanitary Sewer Construction Permit

C. AGENCY: Indiana Department of Environmental Management - Stream Pollution Control Board

D. AUTHORITY: I.C. 13-1-3-7; 13-1-4-2; 13-7-7-5;13-1-3-10;13-710-1

E. APPLICABLE REGULATIONS/STANDARDS: 330 I.A.C. 3.1-2-1(d) Permit is not required if sewer is serving a population equivalent of less than 25 or the waste flow is less than 2,500 gallons per day.

G. APPI.ICATION AND PREREQIIISITE REQUIREMENTS:

H. PROCESSING REQUIREMENTS:

1. Number of Forms: One set of plans and specifications capable of being microfilmed, project design summary 60 days prior to proposed date to start construction.

5. Appeals: Petition within 15 days.

I. NATURE OF APPROVAL:

2. Duration of Permit: Not to exceed 5 years.

J. ASSOCIATED AND/OR FOLLOW-ON PERMITS: Submit as built plans 330 I.A.C. 3.1-3-1. Operation permits 330 I.A.C. 3.1-4-1. 
A. NAME OF PERMIT: Permit to Construct, Install or Modify Facilities, Equipment or Devices for Public Water Supply

B. APPLICABILITY/DESCRIPTION:

C. AGENCY: Indiana Department of Environmental Management. Office of Water Management.

D. AUTHURITY: I.C. 13-7-10-1 (2) (A)

H. PROCESSING REQUIREMENTS:

5. Appeals: Petition within 15 days

I. NATURE UF APPROVAL:

2. Duration of Permit: Not to exceed 5 years 
A. NAME OF PERMIT: Underground Injection Control Permit

B. APPLICABILITY/DESCRIPTION: Applies to any owner or operator who constructs, operates, maintains, converts, plugs, abandons, or conducts any injection activity in a manner that allows movement of fluid containing any contaminant into underground sources of drinking water, if the presence of that contaminant may cause a violation of any drinking water regulation under 40 C.F.R. 142.

C. AGENCY: Administered by E.P.A.

E. APPLICABLE REGULATIONS/STANDARDS: 40 C.F.R. 147.741

Q. APPLICATION AND PREREQUISITE REQUIREMENTS: Application requires information concerning nature and type of injection, location and depth of wells, groundwater monitoring, analysis of injected fluids, description of geologic date.

H. PROCESSING REQUIREMENTS:

4. Fee Schedule/Bond: Owner or operator must establish financial assurance for plugging and abandonment.

I. NATURE OF APPROVAL:

2. Duration of Permit: 10 year duration

3. Conditions: Proper operation and maintenance of facilities and systems of treatment and control, compliance with requests, allowance of entry and inspection, monitoring, record keeping, periodic reporting, reporting of noncompliance, meet criteria of 40 C.F.R. 146. 
A. NAME OF PERMIT: Hazardous Waste Facilities

C. AGENCY: Indiana Environmental Management Board Stream Pollution Control Board

D. AUTHORITY: I.C. 13-7-8.5-5, 13-7-4-1, 13-7-10-1

E. APPLICABLE REGULATIONS/STANDARDS: I.A.C. 320 I.A.C. 4.1; 40 CFR 270. Regulations follow requirements of Federal Program.

G. APPLICATION. AND PREREQUISITE REQUIREMENTS: Hazardous waste facility permits require contingency plans for effective containment and control of any emergency condition resulting from an unanticipated occurrence, proof of financial capability of operator and owner of facility.

H. PROCESSING REQUIREMENTS:

3. Hearing Requirements/Notice: Upon request of Applicant or 100 adults (1.C. 13-7-10-2)

5. Appeals: Petition within 15 days.

I. NATURE UF APPROVAL:

2. Duration of Permit: Not to exceed 5 years.

J. ASSOCIATED AND/OR FOLLOW-ON PERMITS: Manifests form for accompanying any hazardous waste from point of generation through treatment, storage or disposal. 


\section{$\underline{30090}$}

A. NAME OF PERMIT: Endangered Species Protection

C. AGENCY: I.C. 14-2-8.5-7.

E. APPLICABLE REGULATIUNS/STANDARDS: Department of Natural Resources

G. APPLICATION AND PREREQUISITE REQUIREMENTS: It is unlawful to take, possess, transport, export, process, sell or offer for sale or ship endangered species.

I. NATURE OF APPROVAL:

1. Form of Approval: Permit required to take, possess, transport, export, or ship. 
A. NAME OF PERMIT: Permit to Investigate Historic Property

C. AGENCY: Department of Natural Resources

D. AUTHORITY: I.C. 14-3-3.4-8. A person who knowingly, without a permit, conducts a field investigation or alters nistoric property within the boundaries of property owned or leased by the state commits a class B misdemeanor. 
A. NAME OF PERMIT: Surface Mining Permit

C. AGENCY: Department of Natural Resources of the State of Indiana

G. APPLICATIUN AND PREREQUISITE REQUIREMENTS: The permit application requires general information about the owners and neighboring owners, consents for access, and proposed mining and reclamation plan.

H. PROCESSING REQUIREMENTS:

4. Fee Schedule/Bond: Bond is required.

5. Appeals: Appeal to Court of general jurisdiction.

J. ASSOCIATED AND/OR FOLLOW-ON PERMITS: Report of operation within sixty days after the entry of the expiration of any permit or completion or abandonment of the operation for which a permit was issued. 
A. NAME OF PERMIT: Surface Mining Project

C. AGENCY: Natural Resources Commission

D. AUTHURITY: I.C. 13-4-5-1 et seq. No person shall engage in surface mining unless such person possesses a valid permit obtained from the commission designating the area of land affected by the operator.

E. APPLICABLE REGULATIONS/STANDARDS: Application shall describe the acreage, owners, names of owners within 500' of affected area, consents, proposed methods of operation, maps drainage plan, reclamation plan.

H. PROCESSING REQUIREMENTS:

4. Fee Schedule/Bond: $\$ 2,000.00$ plus miscellaneous other fees. 


\section{9}

A. NAME OF PERMIT: Report of Operation

C. AGENCY: Natural Resources Commission

D. AUTHORITY: I.C. : 14-4-6-7

F. PRECEDENT PERMITS: Mine and reclamation plan.

G. APPLICATION AND PREREQUISITE REQUIREMENTS: Report shall be filed 60 days after expiration of any permit or completion of abandonment.

J. ASSOCIATED AND/OR FULLOW-ON PERMITS: Report described affected land to enable release of bonds. 
A. NAME OF PERMIT: Permit to Drill Test Holes

C. AGENCY: Indiana Department of Natural' Resources - 0il and Gas Division

D. AUTHORITY: I.C. 13-4-7-15

G. APPLICATION AND PREREQUISITE REQUIREMENTS: Permit may de required to drill. Permit requires plugging, furnishing of logs, samples, from test noles. 


\section{1}

A. NAME OF PERMIT: Handling or Storing of Explosives

C. AGENCY: State Fire Marshal

D. AUTHORITY: I.C. 22-11-13-1 et seq.

I. NATURE UF APPROVAL:

1. Form of Approval: Fire Marshal shall inspect handling and storing of explosives. 
A. NAME OF PERMIT: Comply with Pipeline Safety Standard

C. AGENCY: Public Service Commission. Safety Division.

D. AUTHURITY: I.C. 8-1-22. Any person engaged in the transportation of gas or who owns, operates or leases pipeline facilities shall certify annualily that it has complied with federal safety standards.

H. PROCESSING REQUIREMENTS:

1. Number of Forms: Must file plan for inspection and maintenance. 
A. NAME OF PERMIT: Permit to Drill Test Hole

C. AGENCY: Department of Natural Resources

D. AUTHORITY: I.C. 13-4-5-4

G. APPLICATION AND PREREQUISITE REQUIREMENTS: Any person desiring to drill one or more test holes for fluid disposal investigation, engineering projects investigation or geologic investigation to a depth of $200^{\circ}$ or more below shall first file a written application for perinit to the commission. 
A. NAME OF PERMIT: Notice of Intent to Plug

C. AGENCY: Department of Natural Resources

D. AUTHORITY: I.C. $13-4-5-8$

G. APPLICATION AND PREREQUISITE REQUIREMENTS: The person in charge of the drilling shall not commence plugging procedures until he has given notice to the commission or its designated representative by personal oral or written notice, telephone, or telegraph. 


\section{2}

A. NAME OF PERMIT: Permit for Significant Deterioration

B. APPLICABILITY/OESCRIPTION: Applies to major stationary sources and major modification.

C. AGENCY: Natural Resources and Environmental Protection Cabinet.

D. AUTHORITY: 114.330

E. APPLICABLE REGULATIONS/STANDARDS: 401 EAR 51:015; 401 KAR 51:017

G. APPLICATION AND PREREQUISITE REQUIREMENTS: Permit requires control technology review, source impact analysis, modelling, monitoring, submittal of data to determine the 1 mpact of emissions on air quality.

H. PROCESSING REQUIREMENTS:

2. Staff Review Time: Note: At least one year of ambient air monitoring is required prior to applying for permit. Staff review time would be at least 180 days.

4. Fee Schedule/Bond: Filing fees vary with cost of project from $\$ 50.00$ to $\$ 2,500.00$ as set out at 401 K.A.R. 50:036. Additional Fees are set for construction and operating permits.

I. NATURE OF APPROVAL:

3. Conditions: Increases in pollution concentration over the baseline concentration are limited to levels specified in regulation. Concentrations of pollutants shall not exceed ambient air ceilings. 
40012.1

A. NAME UF PERMIT: Construction Permit for Air Pollution Discharge or Control

C. AGENCY: Natural Resources and Environmental Protection Cabinet

D. AUTHORITY: K.R.S. 224.033(19); 224.330

E. APPLICABLE REGULATIONS/STANDARDS: 401 KAR 50:005; 401 KAR 50:035

G. APPLICATION AND PREREQUISITE REQUIREMENTS: Applications shall include an analysis of the characteristics, properties, and value of the air contaminant based upon source or stock samples of the air contaminants taken under normal operating conditions.

H. PROCESSING REQUIREMENTS:

2. Staff Review Time: 90 days

4. Fee Schedule/Bond: Fees based upon size of project. 


\section{3}

A. NAME OF PERMIT: Construction Permit for Major Stationary : Source of Air Pollution Discharge or Control

B. APPLICABILITY/DESCRIPTION: Applies to major stationary sources and major modifications

C. AGENCY: Natural Resources and Environmental Protection Cabinet

D. AUTHORITY: K.R.S. 224.033 (19); 224.330

E. APPLICABLE REGULATIUNS/STANDARDS: 401 KAR 50:035

G. APPLICATION AND PREREQUISITE REQUIREMENTS: Applies to major stationary sourccs.

H. PROCESSING REQUIREMENTS:

2. Staff Review Time: 150 days

3. Hearing Requirements/Notice: Public notice and hearing required.

4. Fee Schedule/Bond: Fees based upon size of project. (401 KAR 50:036)

J. ASSOCIATED AND/OR FOLLOW-ON PERMITS: Permit to operate. 
A. NAME OF PERMIT: Construction Permit to Discharge (NPDES)

C. AGENCY: Natural Resources and Environmental Protection Cabinet

D. AUTHORITY: K.R.S. 224.033 (19) and 33 U.S.C. $\$ 1342$ (D) of Federal Water Pollution Control Act. (33U.S.C. $\$ 1251$ et seq.)

E. APPLICABLE REGULATIONS/STANDARDS: 401 KAR 5:050, Sec. 1401 KAR $5: 060$

G. APPLICATION AND PREREQUISITE REQUIREMENTS: Permit is required for discharge of pollutants from any point source into water of commonwealth. Application must include a listing of all environmental permits, or construction approvals issued by the cabinet or other state or federal permits, as requested; maps depicting the facility; and effluent data.

H. PROCESSING REQUIREMENTS:

1. Number of Forms: 3

2. Staff Review Time: Must be submitted not less than 150 days prior to date permit is desired.

I. NATURE OF APPROVAL:

1. Form of Approval: Permit

2. Duration of Permit: Not to exceed 5 years.

3. Conditions: set on a case by case basis.

J. ASSOCIATED AND/OR FOLLOW-ON PERMITS: Operators of facilities must be certified. 
A. NAME OF PERMIT: Underground Injection Control Permit

B. APPLICABILITY/DESCRIPTION: Applies to any owner or operator who constructs, operates, maintains, converts, plugs, abandons, or conducts any injection activity in a manner that allows movement of fluid containing any contaminant into underground sources of drinking water, if the presence of that contaminant may cause a violation of any drinking water regulation under 40 C.F.R. 142.

C. AGENCY: The Kentucky Program administered by E.P.A.

E. APPLICABLE REGULATIUNS/STANDARDS: 40 C.F.R. 147.901

G. APPLICATION AND PREREQUISITE REQUIREMENTS: Application requires information concerning nature and type of injection, location and depth of wells, groundwater monitoring, analysis of injected fluids, description of geologic data.

H. PROCESSING REQUIREMENTS:

4. Fee Schedule/Bond: Owner or operator must establish financial assurance for plugging and abandonment.

I. NATURE OF APPROVAL:

2. Duration of Perinit: 10 year duration

3. Conditions: Proper operation and maintenance of facilities and systems of treatment and control, compliance with requests, allowance of entry and inspection, monitoring. record keeping, periodic reporting, reporting of noncompliance, meet criteria of 40 C.F.R. 146. 
40051

A. NAME OF PERMIT: Permit for Installation, Alteration, Expansion, or Operation of Sewage Systems

C. AGENCY: Natural Resources and Environmental Protection Cabinet

D. AUTHORITY: K.R.S. 224.033 (19)

E. APPLICABLE REGULATIONS/STANDARDS: 401 KAR 5:005, Sec. 2 
40051

A. NAME OF PERMIT: Permit for Waste Disposal Site or Facility

C. AGENCY: Natural Resources and Environmental Protection Cabinet

D. AUTHURITY: K.R.S. 224.842; K.R.S. 224.846; K.R.S. 224.855

E. APPLICABLE REGULATIONS/STANDARDS: 401 KAR 30:050 et seq. Kentucky rules follow federal RCRA requirements.

H: PROCESSING REQUIREMENTS:

3. Hearing Requirements/Notice: 45 day public notice of permit application required, then 30 days must pass prior to issuance

4. Fee Scnedure/Bond: Minimum bond of $\$ 10,000$ per site

1. NATURE UF APPROVAL:

2. Duration of Permit: Approval or disapproval must come within 30 days after the hearing. 
A. NAME OF PERMIT: Hazardous Waste Disposal

C. AGENCY: Natural Resources and Environmental Protection Cabinet

D. AUTHORITY: K.R.S. 224.866; 224.855 (5)

E. APPLICABLE REGULATIONS/STANDARDS: 401 KAR 30:050 et seq. Kentucky rules follow federal RCRA requirements.

G. APPLICATIUN AND PREREQUISITE REQUIREMENTS: Permit is required for construction and operation of facilities to store, treat, recycle, or dispose of hazardous waste. Applicant must show that facility can be integrated into surroundings in environmentally compatible" manner, including hydrologic, seismologic, geologic, and soil consideration.

H. PROCESSING REQUIREMENTS:

2. Staff Review Time: 30 days following nearing.

3. Hearing Requirements/Notice: Notice same as for waste disposal site or facility.

4. Fee Schedule/Bond: Financial ability to close facility must be demonstrated, liability insurance required.

I. NATURE OF APPROVAL:

3. Conditions: Funds to close facility must be available. 
$\underline{40055.1}$

A. NAME OF PERMIT: Hazardous Waste Management

B. APPLICABILITY/OESCRIPTION: Applies to generators, transporters, and receivers of hazardous waste.

D. AUTHORITY: K.R.S. 224.873; K.R.S. 224.874

E. APPLICABLE REGULATIONS/STANDARDS: 401 K.A.R. 30:050

.H: PROCESSING REQUIREMENTS:

1. Number of Forms: A manifest system for tracking hazardous wastes is required for tracking hazardous wastes from generator sets of treatment, storage, and disposal (except for coal mining wastes). 
A. NAME OF PERMIT: Permit to Dispose of Special Wastes

B. APPLICABILITY/DESCRIPTION: Applies to wastes of high volume and low hazard which include, but are not limited to, mining wastes, utility wastes (Fly ash, bottom ash, scrubber sludge), sludge from water treatment facilities and waste water treatment facilities, ...gas and oil drilling muds and oil production brines and wastes designated special wastes.

C. AGENCY: Natural Resources and Environmental Protection Cabinet.

D. AUTHURITY: K.R.S. 224.868. If nazardous waste, disposal is subject to regulations for disposal of hazardous waste. 
A. NAME OF PERMIT: Permit to Excavate Archaeological Site.

C. AGENCY: University of Kentucky, Department of Anthropology.

D. AUTHORITY: KRS 164.720

G. APPLICATIUN AND PREREQUISITE REQUIREMENTS: No person shall explore, excavate, appropriate, or remove from land owned or leased by the commonwealth, or any state agency, or any political subdivision or any municipal corporation...any archaeological site or object of antiquity without first obtaining a permit from the Department of Anthropology.

I. NATURE UIF APPROVAL:

2. Duration of Permit: Until December 31.

3. Conditions: Set as department deems advisable. 


\section{5}

A. NAME OF PERMIT: Permit for Disturbance of Wild Rivers

C. AGENCY: Natural. Resources and Environmental Protection Cabinet.

D. AUTHORITY: KRS 146.222 et seq. The legislature has set up a system to preserve the unique primitive character of those streams which still retain a large portion of their natural and scenic beauty. Emphasis is given to protecting aesthetic, scenic, historic, archaeologic and scientific features. Strip mining and instream disturbances are prohibited. Cutting of timber is limited. Construction of utility lines or pipelines may be permitted.

H. PROCESSING REQUIREMENTS:

2. Staff Review Time: 60 days to review following nearing.

3. Hearing Requirements/Notice: Public hearing within 60 days of application for permit.

5. Appeals: 30 days to appeal decision. Then 60 days to resolve. 
A. NAME OF PERMIT: Mining and Reclamation Permit

C. AGENCY: Natural Resources and Environmental Protection Cabinet

D. AUTHORITY: K.R.S. 350.600

E. APPLICABLE REGULATIONS/STANDARDS: 405 KAR 30:130

F. PRECEDENT PERMITS: Mine Safety and Health Administration I.D. Number.

G. APPLICATION AND PREREQUISITE REQUIREMENTS: Application will inclucle yeneral information concerning the applicant. detailed descriptions of the area to be mined; drainage plan, use of explosives plan, top soil handling and restoration plan; backfilling and grading plan; revegetation plan; spoil and spent shale disposal pian; and demonstration of compliance with waste management, surface water control, hydrologic, water quality, sediment control, air, fish and wildife regulations and baseline data for air, water, land, plants, and wildlife.

H. PROCESSING REQUIREMENTS:

2. Staff Review Time: 30 days - on site visit; 30 days advertisement of public notice of intent prior to submitting application.

4. Fee Schedule/Bond: $\$ 500$ plus $\$ 50$ per acre-mintmum Dond of $\$ 20,000$.

I. NATURE OF APPROVAL:

2. Duration of Permit: 5 years 
40253.1

A. NAME OF PERMIT: Exploration Permit of Less than 250 Tons of Shate Moved

B. APPLICABILITY/OESCRIPTION: Applies to exploration activities of less than 250 tons.

C. AGENCY: Natural Resources and Environmental Protection Cabinet.

.D. AUTHORITY: K.R.S. 350.600

E. APPLICABLE REGULATIUNS/STANDARDS: 405 K.A.R. 30:121

G. APPLICATION AND PREREQUISITE REQUIREMENTS: Application requires 21 day notice to Cabinet and restoration if exploration substantially disturbs any natural land surface.

H. PROCESSING REQUIREMENTS:

2. Staff Review Time: 21 days

I. NATURE OF APPROVAL: 


\section{2}

A. NAME UF PERMIT: Exploration Permit More than 250 Tons of: Shale Moved

C. AGENCY: Natural Resources and Environmental Protection Cabinet.

D. AUTHORITY: K.R.S. 350.600

E: APPLICABLE REGULATIUNS/STANDARDS: 405 K.A.R. 30:121

G. APPLICATION AND PREREQUISITE REQUIREMENTS: APplication requires plans for compliance with Kentucky performance standards.

H. PRUCESSING REQUIREMENTS:

2. Staff Review Time: 21 day review for completeness. 60 days to act on application following filing. 
- A. NAME UF PERMIT: Notice of Mine Abandonment

C. AGENCY: Department of Mines and Minerals

D. AUTHORITY: KRS 552.420

I. NATURE UF APPROVAL:

1. Form of Approval: Notice to department of intent to abandon. 
40600

A. NAME UF PERMIT: Permit Authorizing Transportation of Petroleum Product

C. AGENCY: Bureau of Vehicle Regulation

D. AUTHORITY: KRS 281.627. Certificate or permit required for transportation of petroleum and petroleum products in bulk and tank trucks.

I. NATURE OF APPROVAL:

3. Conditions: Certificate of public convenience and necessity.

344 
A. NAME OF PERMIT: Motor Carrier Permit for Communication Buses

C. AGENCY: Bureau of Venicle Regulation

D. AUTHORITY: KRS $281.615 ; 281.605$ (II). No person shall act as a motor carrier without first having obtained a certificate or permit. Applies to buses with a seating capacity exceeding 15 passengers. 
A. NAME OF PERMIT: Certificate of Convenience for Pipeline

C. AGENCY: Utility Regulatory Commission

D. AUTHURITY: KRS 278.020. No person, partnership, public or private corporation or combination thereof shall begin the construction of any plant, equipment, property, or facility...until such person has obtained a certificate that public convenience and necessity require such construction. 
A. NAME OF PERMIT: Permit to Transport Hazardous Substances

C. AGENCY: Department of Transportation

D. AUTHORITY: KRS 174.400 et seq. No person shall haul, transport, or cause to be transported any hazardous or radioactive material without a permit.

E. APPLICABLE REGULATIUNS/STANDARDS: Federal Hazardous Materials Transportation Regulation. 49 CFR (1978)

I. NATURE OF APPROVAL:

3. Conditions: Must carry shipping papers and hazardous waste manifest. 
$\underline{40655.1}$

A. NAME OF PERMIT: Permit to Transport Explosives

C. AGENCY: Railroad Commission; and Natural Resources and Environmental Protection Cabinet.

D. AUTHORITY: KRS 276.450. No person shall transport any explosives compound in violation of rules prescribed and published by the railroad commission.

H. PROCESSING REQUIREMENTS:

2. Staff Review Time: 60 days. 
40700

A. NAME OF PERMIT: Noise Pollution Abatement

C. AGENCY: Secretary for Natural Resources and Environmental Protection

D. AUTHURITY: K.R.S. 224.710 et seq.

I. NATURE OF APPROVAL:

1. Form of Approval: Comply with noise standards. 


\section{1}

A. NAME OF PERMIT: Certificate of Environmental Compatability

C. AGENCY: Utility Regulatory Commission

D. AUTHORITY: KRS 278.025. No person.... shall begin construction of any facility to be used for the generation of electricity to or for the public for compensation without having first obtained... a certificate of environmental compatability. 
A. NAME OF PERMIT: Approval of Research and Development Projects

B. APPLICABILITY/DESCRIPTION: Applies to $R \& D$ projects to be supported by Energy Development Trust Funds

C. AGENCY: Energy Cabinet

D. AUTHORITY: KRS 152A.011 et seq. Oversees and encourages energy $R$ \& $D$.

I. NATURE UF APPROVAL:

1. Form of. Approval: No approvals. 


\section{$\underline{40990}$}

A. NAME OF PERMIT: Tax Exemption Certificate

B. APPLICABILITY/DESCRIPTION: Applies to air, noise, waste or water pollution control equipment.

C. AGENCY: Department of Revenue.

D. AUTHORITY: K.R.S. 224.852 
